

\section{A COMPARATIVE STUDY OF CORPORATE SUSTAINABILITY, STRATEGIC CORPORATE SOCIAL RESPONSIBILITY AND MARKET VALUE CREATION AMONG COMPANIES OPERATING IN INDIA}

Satish Kumar Damodar 


\title{
A COMPARATIVE STUDY OF CORPORATE SUSTAINABILITY, STRATEGIC CORPORATE SOCIAL RESPONSIBILITY AND MARKET VALUE CREATION AMONG COMPANIES OPERATING IN INDIA
}

\author{
DISSERTATION \\ to obtain \\ the degree of doctor at the Universiteit Twente, \\ on the authority of the rector magnificus, \\ prof. dr. ir. A. Veldkamp, \\ on account of the decision of the Doctorate Board \\ to be publicly defended \\ on Thursday May 6th, 2021 at 12.45 hours
}

by

\section{Satish Kumar Damodar}

born on the 25th of May, 1964

in

Poona, India 
This dissertation has been approved by:

Supervisor

prof. dr. ir. J. van Hillegersberg

Co-supervisor

dr. J. Kundi

Cover design: $\quad$ University of Twente

Printed by:

Lay-out:

ISBN:

978-90-365-5189-2

DOI: $\quad 10.3990 / 1.9789036551892$

https://doi.org/10.3990/1.9789036551892

(C) 2021 Satish Kumar Damodar, The Netherlands.

All rights reserved. No parts of this thesis may be reproduced, stored in a retrieval system or transmitted in any form or by any means without permission of the author. Alle rechten voorbehouden. Niets uit deze uitgave mag worden vermenigvuldigd, in enige vorm of op enige wijze, zonder voorafgaande schriftelijke toestemming van de auteur. 


\section{Graduation Committee:}

Chair / secretary:

Supervisor:

Co-supervisor:

Committee Members: prof. dr. T. A. J. Toonen

prof. dr.ir. J. van Hillegersberg

dr. J. Kundi

prof. dr. M. Junger

prof. dr. M. R. Kabir

prof. dr. V. B. Marisetty

dr. S.O. Idowu 


\section{ABSTRACT}

'A comparative study of corporate sustainability, strategic corporate social responsibility and market value creation among companies operating in India' is an original research carried out in India. The study consists of two parts-qualitative and quantitative. The qualitative part includes practice-oriented study on corporate sustainability (CS) and corporate social responsibility (CSR) initiatives undertaken by multinational companies, Indian private companies and public sector enterprises operating in India. The quantitative part includes study on five dimensions of strategic CSR (Burke \& Logsdon 1996); the pyramid of CSR (Carroll 1991); three components of CSR, namely principles of charity, stewardship (Lawrence, Weber \& Post 2005), and environmental friendliness for market value creation among enterprises operating in India. The research design is a mixed sequential exploratory model (Tashakkori \& Teddlie 2003) wherein qualitative research followed by quantitative research for theory development and testing.

The qualitative research involves information gathered through author's own two decades of industry experience; gathering information and interacting with senior management professionals practicing CS and/or CSR in 43 companies (multinationals, Indian private and public sector enterprises) operating in India. The validity of data gathered through qualitative research is determined through triangulation, pattern matching and member checking. The analysis of qualitative data was undertaken using thematic analysis- coding, data reduction, categorization, and theme development. The themes derived from clusters of companies analyzed, compared in terms of CS and CSR initiatives. The qualitative study reflects relative performance of $C S$ and CSR per company in descending order as: PSE (2.70), Indian private (2.18) and MNC (1.00).

The quantitative research formulates hypotheses based on the Burke \& Logsdon's (1996) five dimensions of strategic CSR; four corporate 
responsibilities- Carroll's pyramid of CSR, Lawrence et al.'s principle of charity \& stewardship, and environmental responsibility. Questionnaires 2 \& 3 (Annexure I) on quantitative study were administered to 520 organizations in the above categories using probability (simple random) sampling method. 93 companies responded with completed questionnaires. The results obtained from the samples were analyzed using SPSS. Reliability test using Cronbach's alpha suggest a value greater than 0.70 meeting the requirements of reliability.

The quantitative research involves descriptive statistics, correlation analyses, regression analysis 1 followed by factor analysis (factor reduction), and subsequently regression 2 . The results of the quantitative study confirm the following:

- Only the three dimensions of strategic CSR (centrality, proactivity and visibility), two categories of corporate responsibilities (legal and philanthropy) and all the three components of CSR (charity, stewardship and environmental friendliness) create value for the multinational companies operating in India.

- All the five dimensions of strategic CSR (centrality, specificity, proactivity, voluntarism and visibility), all the four categories of corporate responsibilities (economic, legal, ethical and philanthropy) and the three components of CSR (charity, stewardship and environmental friendliness) create value for the Indian private companies operating in India.

- Only three dimensions of strategic CSR (proactivity, visibility, and voluntarism), all the four categories of corporate responsibilities (economic, legal, ethical and philanthropy) create value for the public sector enterprises operating in India. 


\section{ACKNOWLEDGEMENTS}

This thesis is the result of my doctoral research at the department of Industrial Engineering and Business Information Systems, Faculty of Behavioural, Management and Social Sciences at the University of Twente. Undertaking this research has helped me learn in depth in understanding and analyzing qualitative and quantitative research methodologies.

I am grateful to my supervisors late prof. dr. Kuldeep Kumar, prof. dr. Jos van Hillegersberg and dr. Jag Kundi for their supervision, encouragement and unwavering support right from the beginning of my research at University of Twente.

I thank the members of doctoral committee prof. dr. M. Junger (University of Twente), prof. dr. M. R. Kabir (University of Twente), prof. dr. V. B. Marisetty (University of Hyderabad) and dr. S. O. Idowu (Guildhall School of Business and Law) for their comments and suggestions.

My sincere thanks to prof. dr. Susan E McKenney (University of Twente), dr. Eugene C Ikejemba (University of Twente) for their continuous encouragement and support during my research. I would also like to thank prof. dr. P. M. van Dijk (University of Twente) for his support. I am grateful to my colleagues Ahmed A Kassim (Dire Dawa University), dr. Amarnath Bose (Birla Institute of Management Technology), Irina Vorobyov (Cherepovets State University), and Mesfin (Dire Dawa University) for their continuous support, encouragement and feedback related to quantitative study.

Finally, I would like to thank all professionals from the industry, members of ASSOCHAM (Indian Chamber of Commerce), my colleagues from academia and industry, and family members for their genuine and prompt guidance in ensuring successful accomplishment of this research. 
DEFINITIONS

Adivasis

Arthashastra

Caste-ism

Crore

Dalits

Kudumbashree

Lakh

Maharatna

Miniratna

Navratna

Naxalite

Panchayat

Schedule Caste/ Scheduled Tribe

Sikhism members of any of the aboriginal tribal peoples living in India

an ancient Indian treatise on statecraft, economic policy, and military strategy, written by Chanakya in Sanskrit

adherence to a caste system

ten million

members of the lowest caste in the Indian social ladder

poverty eradication \& women's empowerment programme by the State Poverty Eradication Mission, Government of Kerala

one hundred thousand

Indian public sector enterprise with an annual net profit of over INR25,000 million ( $\$ 412.95$ million) for three years. To be eligible, a public sector enterprise must have a net worth of INR100,000 million ( $\$ 1651.80$ million) and annual turnover of INR200,000 million (\$3303.60 million) for three years (BSE 2014)

Miniratna category 1 public sector enterprise should have made profits continuously for the last three years OR must have earned a net profit of INR300 million (\$4.955 million) or more in one of the three years. Miniratna category 2 public sector enterprises should have made profits continuously for the last three years and should have a positive net worth (BSE 2014)

Indian public sector enterprise with a score of $60 \%$ based on 6 parameters- net profit, net worth, total manpower cost, total cost of production, cost of services, Profit Before Depreciation, Interest and Taxes (PBDIT), capital employed, etc. AND a company must be first a Miniratna and have 4 Independent Directors on Board (BSE 2014)

a member of an extreme Maoist rebel group in India that originated in 1967

a village council in India

officially designated groups of historically disadvantaged people in India

a monotheistic religion founded in Punjab region in India in the 15th century by Guru Nanak 
Currency Exchange Rates (as on $29^{\text {th }}$ August 2014)

www.xe.com/currencycharts/

US\$1 = INR 60.54 INR1 $=1 / 60.54=\$ 0.016518$

Currency Exchange Rates (as on $31^{\text {st }}$ March 2013)

www.xe.com/currencycharts/

\begin{tabular}{|c|c|c|c|c|c|}
\hline US\$1 & $=$ & INR 54.285 & INR1 & $=$ & $1 / 54.285=\$ 0.0184$ \\
\hline US\$1 & $=$ & $€ 0.7799$ & $€ 1$ & $=$ & $1 / 0.7799=\$ 1.2822$ \\
\hline US\$1 & $=$ & £ 0.6576 & f1 & $=$ & $1 / 0.6576=\$ 1.5206$ \\
\hline US\$1 & $=$ & CHf 0.9489 & CHf1 & $=$ & $1 / 0.9489=\$ 1.0538$ \\
\hline US\$1 & $=$ & $¥ 94.215$ & $¥ 1$ & $=$ & $1 / 94.215=\$ 0.0106$ \\
\hline US\$1 & $=$ & SEK 6.5241 & SEK1 & $=$ & $1 / 6.5241=\$ 0.1532$ \\
\hline
\end{tabular}

Note:

Please note that the decimal separator used in the number system is a full stop (.); for eg., $100.00=$ one hundred; and 100,000.00 $=$ one hundred thousand. 


\begin{tabular}{|c|c|c|}
\hline A4S & $:$ & Accounting for Sustainability \\
\hline ASSOCHAM & : & Associated Chambers of Commerce and Industry of India \\
\hline BBC & : & British Broadcasting Corporation \\
\hline BP & : & British Petroleum \\
\hline BSE & : & Bombay Stock Exchange \\
\hline BU & : & Billion Units (equal to Terrawatt Hour TWh) \\
\hline $\mathrm{CHF}$ & : & Confoederatio Helvetica (Swiss Franc) \\
\hline CSP & : & Corporate Social Performance \\
\hline CS & : & Corporate Sustainability \\
\hline CSR & : & Corporate Social Responsibility \\
\hline DRF & : & Dr Reddy's Foundation \\
\hline EMPRESA & : & Instituto de Empresa (part of IE University) \\
\hline GCMMF & : & Gujarat Cooperative Milk Marketing Federation \\
\hline GRI & : & Global Reporting Initiative \\
\hline IFAC & : & International Federation of Accountants \\
\hline IFCN & : & International Farm Comparison Network \\
\hline IIRC & : & International Integrated Reporting Council \\
\hline IISD & : & International Institute of Sustainable Development \\
\hline ILO & : & International Labour Organization \\
\hline Indian Private & : & Indian Private companies/enterprises \\
\hline INR & : & Indian Rupees \\
\hline ISO & : & International Organization for Standardization \\
\hline IUCN & : & International Union for Conservation of Nature \\
\hline LEED & : & Leadership in Energy and Environmental Design \\
\hline MNCs & : & Multinational Corporations/Companies \\
\hline MPI & : & Multidimensional Poverty Index \\
\hline NGOs & : & Non-Governmental Organizations \\
\hline OECD & : & Organization for Economic Cooperation \& Development \\
\hline ppm & : & parts per million \\
\hline PPP & : & Purchasing Power Parity \\
\hline PSEs & : & Public Sector Enterprises \\
\hline RBV & : & Resource Based View \\
\hline SAAR & : & Social Accounting, Auditing \& Reporting \\
\hline SACOM & : & Students and Scholars against Corporate Misbehaviour \\
\hline SDGs & : & Sustainable Development Goals \\
\hline SEK & : & Swedish Krona \\
\hline SMES & : & Small and Medium Enterprises \\
\hline SPSS & : & Statistical Package for Social Science \\
\hline SRI & : & Socially Responsible Investing \\
\hline UN & : & United Nations \\
\hline UNEP & : & United Nations Environmental Programme \\
\hline UNCTAD & : & United Nations Conference on Trade and Development \\
\hline VIF & : & Variance Inflation Factor \\
\hline WBCSD & : & World Business Council for Sustainable Development \\
\hline WCED & : & World Commission on Environment \& Development \\
\hline WEF & : & World Economic Forum \\
\hline WWF & : & World Wildlife Fund \\
\hline
\end{tabular}




\section{TABLE OF CONTENTS}

\begin{tabular}{|l|l|l|}
\hline S No. & Particulars & Page No \\
\hline 1.0 & INTRODUCTION TO CORPORATE SOCIAL RESPONSIBILITY & 1 \\
\hline 1.1 & Background of the study & 1 \\
\hline 1.2 & Objectives & 3 \\
\hline 1.3 & Research questions & 4 \\
\hline 1.4 & Significance of the study & 4 \\
\hline 1.5 & Scope of the study & 5 \\
\hline 1.6 & Why India has been chosen for the study & 5 \\
\hline 1.7 & Reason for studying strategic CSR and Corporate responsibilities & 10 \\
\hline 1.8 & ORGANIZATION OF REST OF THE THESIS & 11 \\
\hline
\end{tabular}

\begin{tabular}{|l|l|l|}
\hline 2.0 & CONCEPTS \& THEORIES OF CSR & 14 \\
\hline 2.1 & Definitions of corporate social responsibility & 14 \\
\hline 2.2 & History of corporate social responsibility & 15 \\
\hline 2.3 & Dimensions of strategic CSR & 17 \\
\hline 2.4 & Pyramid of CSR & 24 \\
\hline 2.5 & CSR related to charity and stewardship & 27 \\
\hline 2.6 & CSR and environmental challenges & 27 \\
\hline 2.7 & Empirical results from previous studies \& its relevance & 28 \\
\hline 2.8 & Theoretical viewpoints on corporate social responsibility & 31 \\
\hline 2.9 & Importance of viewpoints on CSR & 44 \\
\hline 2.10 & Guidelines related to CSR & 44 \\
\hline 2.11 & CSR as a catalyst & 47 \\
\hline
\end{tabular}

\begin{tabular}{|l|l|l|}
\hline 3.0 & IMPORTANCE OF STRATEGIC CSR IN CREATING STAKEHOLDER VALUE & 50 \\
\hline 3.1 & Introduction & 50 \\
\hline 3.2 & CSR \& organizational performance & 50 \\
\hline 3.3 & CSR, value chain and context of competitiveness & 51 \\
\hline 3.4 & Benefits of CSR to the corporation & 53 \\
\hline 3.5 & Response to CSR programmes & 55 \\
\hline 3.6 & CSR and corporate identity & 57 \\
\hline 3.7 & Catalyzing CSR in emerging markets & 65 \\
\hline 3.7 .1 & CSR in Asia & 66 \\
\hline 3.7 .2 & CSR in Africa & 68 \\
\hline 3.7 .3 & CSR in Latin America & 69 \\
\hline 3.8 & Factors contributing to CSR in emerging markets & 71 \\
\hline 3.9 & Categories of CSR activities & 75 \\
\hline 3.10 & Issues related to CSR & 76 \\
\hline 3.11 & Gaps in literature & 76 \\
\hline 3.12 & Hypotheses and its rationale & 77 \\
\hline
\end{tabular}

\begin{tabular}{|l|l|l|}
\hline 4.0 & RESEARCH METHODOLOGY & 85 \\
\hline 4.1 & Research approach & 85 \\
\hline
\end{tabular}




\begin{tabular}{|l|l|l|}
\hline 4.2 & Research design & 86 \\
\hline 4.3 & Research strategy & 86 \\
\hline 4.4 & Method of data collection and tools & 87 \\
\hline 4.5 & Sampling & 88 \\
\hline 4.6 & Methods of analyses & 95 \\
\hline 4.7 & Variables & 99 \\
\hline 4.8 & Validity and reliability & 104 \\
\hline 4.9 & Comparison of current methodology with that of prior studies & 106 \\
\hline
\end{tabular}

\begin{tabular}{|l|l|l|}
\hline 5.0 & $\begin{array}{l}\text { CORPORATE SUSTAINABILITY \& CSR INITIATIVES IN THE INDIAN CORPORATE } \\
\text { SECTOR (Qualitative study) }\end{array}$ & 110 \\
\hline 5.1 & Introduction to corporate sustainability & 110 \\
\hline 5.2 & Researcher's experience in CS/CSR as a part of marketing strategy & 114 \\
\hline 5.3 & CS \& CSR practices in the Indian corporate sector & 120 \\
\hline 5.3 .1 & CS \& CSR practices of multinational companies & 121 \\
\hline 5.3 .2 & CS \& CSR practices of Indian private companies & 144 \\
\hline 5.3 .3 & CS \& CSR practices of public sector enterprises & 159 \\
\hline 5.4 & Thematic analyses & 174 \\
\hline 5.4 .1 & Thematic analysis of data from multinational companies & 177 \\
\hline 5.4 .2 & Thematic analysis of data from Indian private companies & 179 \\
\hline 5.4 .3 & Thematic analysis of data from public sector enterprises & 181 \\
\hline 5.4 .4 & Comparison of CS \& CSR among clusters of companies & 182 \\
\hline 5.5 & Benefits of corporate sustainability \& CSR & 184 \\
\hline
\end{tabular}

\begin{tabular}{|l|l|l|}
\hline 6.0 & $\begin{array}{l}\text { DIMENSIONS OF STRATEGIC CSR \& RESPONSIBILITIES OF COMPANIES OPERATING } \\
\text { IN INDIA (Quantitative study) }\end{array}$ & 187 \\
\hline 6.1 & Introduction & 187 \\
\hline 6.2 & Descriptive statistics & 188 \\
\hline 6.3 & Correlation analyses & 193 \\
\hline 6.4 & Regression model 1 (R1) & 196 \\
\hline 6.5 & Factor analyses & 205 \\
\hline 6.6 & Regression model 2 (R2) & 219 \\
\hline 6.7 & Reliability test & 239 \\
\hline
\end{tabular}

\begin{tabular}{|l|l|l|}
\hline 7.0 & CONCLUSIONS & 241 \\
\hline 7.1 & Introduction & 241 \\
\hline 7.2 & Conclusions from the study & 242 \\
\hline 7.3 & Approaches to social value creation & 249 \\
\hline 7.4 & Applicability of research findings & 251 \\
\hline 7.5 & CSR and stakeholders & 251 \\
\hline 7.6 & Proposed framework & 254 \\
\hline 7.7 & Future recommendations & 256 \\
\hline 7.8 & Limitations & 260 \\
\hline 7.9 & Concluding remarks & 261 \\
\hline & REFERENCES & 262 \\
\hline
\end{tabular}




\begin{tabular}{|l|l|}
\hline \multicolumn{2}{|l|}{ LIST OF ANNEXURES } \\
\hline I & Questionnaires 1, 2 \& 3 for MNCs, Indian private \& PSEs (qualitative \& quantitative) \\
\hline II & $\begin{array}{l}\text { Sector-wise list of MNCs, Indian private companies \& PSEs sampled in the qualitative } \\
\text { \& quantitative studies }\end{array}$ \\
\hline III & List of companies sampled in the qualitative and quantitative studies \\
\hline IV & $\begin{array}{l}\text { Views of respondents with regard to dimensions of strategic CSR } \\
\text { Views of respondents on responsibilities of companies }\end{array}$ \\
\hline V & Residual statistics and graphs plotted under Regression 1 for all companies \\
\hline VI & Residual statistics of regression 2 for all companies \\
\hline VII & Cronbach's alpha: Item statistics \\
\hline
\end{tabular}

\begin{tabular}{|c|c|c|}
\hline & LIST OF TABLES & \\
\hline 1 & Definitions of Corporate Social Responsibility & 14 \\
\hline 2 & Dimensions of strategic CSR & 18 \\
\hline 3 & Strategy linked to CSR and outcome & 21 \\
\hline 4 & Strategic benefits from socially responsible behaviour & 22 \\
\hline 5 & Qualitative study - Consolidated statement of global operations of MNCs & 90 \\
\hline 6 & $\begin{array}{l}\text { Qualitative study - Consolidated statement of operations of Indian private } \\
\text { companies }\end{array}$ & 91 \\
\hline 7 & Qualitative study - Consolidated statement of operations of PSEs & 91 \\
\hline 8 & Quantitative study- Consolidated statement of global operations of MNCs & 92 \\
\hline 9 & $\begin{array}{l}\text { Quantitative study- Consolidated statement of operations of Indian private } \\
\text { companies }\end{array}$ & 93 \\
\hline 10 & Quantitative study- Consolidated statement of operations of PSEs & 94 \\
\hline 11 & Phases of qualitative research & 98 \\
\hline 12 & Independent variables & 100 \\
\hline 13 & Dependent variable & 102 \\
\hline 14 & Control variables & 102 \\
\hline 15 & Comparison of present study with that of previous similar studies & 107 \\
\hline 16 & Projects undertaken by HPCL during the year 2010-2011 & 169 \\
\hline 17 & CSR initiatives undertaken by HUDCO & 171 \\
\hline 18 & Thematic analysis of data from MNCs & 177 \\
\hline 19 & Thematic analysis of data from Indian private companies & 179 \\
\hline 20 & Thematic analysis of data from PSEs & 181 \\
\hline 21 & Comparison of CS and CSR among the clusters of companies & 183 \\
\hline 22 & Descriptive statistics- Mean, standard deviation \& percentiles & 188 \\
\hline 23 & Correlation analysis of variables in dimensions of strategic CSR and value creation & 194 \\
\hline 24 & Correlation analysis of variables in responsibilities of companies and value creation & 194 \\
\hline 25 & Test of multicollinearity among MNCs under regression 1 & 197 \\
\hline 26 & Regression 1 outcomes among multinational companies & 198 \\
\hline 27 & Test of multicollinearity among Indian private companies under regression 1 & 200 \\
\hline 28 & Regression 1 outcomes among Indian private companies & 201 \\
\hline 29 & Test of multicollinearity among public sector enterprises under regression 1 & 203 \\
\hline 30 & Regression 1 outcomes among public sector enterprises & 204 \\
\hline 31 & Total variances explained for MNCs & 207 \\
\hline
\end{tabular}




\begin{tabular}{|l|l|l|}
\hline 32 & Component matrices for MNCs & 208 \\
\hline 33 & Rotated component matrices for MNCs & 209 \\
\hline 34 & Component transformation matrices for MNCs & 210 \\
\hline 35 & Total variances explained for Indian private companies & 211 \\
\hline 36 & Component matrices for Indian private companies & 212 \\
\hline 37 & Rotated component matrices for Indian private companies & 213 \\
\hline 38 & Component transformation matrices for Indian private sector companies & 214 \\
\hline 39 & Total variances explained for public sector enterprises & 215 \\
\hline 40 & Component matrices for public sector enterprises & 216 \\
\hline 41 & Rotated component matrices for public sector enterprises & 217 \\
\hline 42 & Component transformation matrices for public sector enterprises & 218 \\
\hline 43 & Test of multicollinearity for MNCs under regression 2 & 222 \\
\hline 44 & Regression 2 outcomes among MNCs & 223 \\
\hline 45 & Test of multicollinearity for Indian private companies under regression 2 & 229 \\
\hline 46 & Regression 2 outcomes among Indian private companies & 230 \\
\hline 47 & Test of multicollinearity for public sector enterprises under regression 2 & 236 \\
\hline 48 & Regression 2 outcomes among public sector enterprises & 237 \\
\hline 49 & Reliability statistic & 239 \\
\hline
\end{tabular}

\begin{tabular}{|l|l|l|}
\hline \multicolumn{2}{|l|}{ LIST OF FIGURES } & 13 \\
\hline 1 & Organization of the thesis & 18 \\
\hline 2 & Dimensions of strategic CSR & 24 \\
\hline 3 & Pyramid of CSR & 32 \\
\hline 4 & Viewpoint of corporate social responsibility (Garriga \& Melé) & 33 \\
\hline 5 & Viewpoint of corporate social responsibility (Secchi) & 37 \\
\hline 6 & Stakeholder view of a firm & 39 \\
\hline 7 & CSR activities with salient stakeholders & 41 \\
\hline 8 & Classification of stakeholders & 45 \\
\hline 9 & Seven areas of social responsibility & 52 \\
\hline 10 & CSR activities contributing to value chain of the firm & 53 \\
\hline 11 & CSR activities improving the context of competitiveness of the firm & 82 \\
\hline 12 & Social enterprise combining social good and commercial goals & 85 \\
\hline 13 & The research onion diagram & 95 \\
\hline 14 & Deciding on type of practice-oriented research & 110 \\
\hline 15 & Evolution of corporate sustainability & 112 \\
\hline 16 & Dimensions of corporate sustainability & 174 \\
\hline 17 & Qualitative analysis continuum & 175 \\
\hline 18 & Theme development in qualitative research & 176 \\
\hline 19 & Generating themes through data reduction method & 206 \\
\hline 20 & Steps in factor analysis & 219 \\
\hline 21 & Test of normality for MNCs under regression 2 (ZRESID vs frequency) & 220 \\
\hline 22 & Test of normality for MNCs under regression 2 (Normal plot of ZRESID) & 220 \\
\hline 23 & Test of heteroscedasticity for MNCs under regression 2 (ZPRED \& ZRESID) & 221 \\
\hline 24 & Test of linearity for MNCs under regression 2 (ZPRED vs value creation) & 226 \\
\hline 25 & Test of normality for Indian private companies under regression 2 \\
\hline
\end{tabular}




\begin{tabular}{|l|l|l|}
\hline & (ZRESID vs frequency) & \\
\hline 26 & $\begin{array}{l}\text { Test of normality for Indian private companies under regression 2 } \\
\text { (Normal plot of ZRESID) }\end{array}$ & 227 \\
\hline 27 & $\begin{array}{l}\text { Test of heteroscedasticity for Indian private companies under regression 2 } \\
\text { (ZPRED \& ZRESID) }\end{array}$ & 227 \\
\hline 28 & $\begin{array}{l}\text { Test of linearity for Indian private companies under regression 2 } \\
\text { (ZPRED vs value creation) }\end{array}$ & 228 \\
\hline 29 & $\begin{array}{l}\text { Test of normality for public sector enterprises under regression 2 } \\
\text { (ZRESID vs frequency) }\end{array}$ & 232 \\
\hline 30 & $\begin{array}{l}\text { Test of normality for public sector enterprises under regression 2 } \\
\text { (Normal plot of ZRESID) }\end{array}$ & 233 \\
\hline 31 & $\begin{array}{l}\text { Test of heteroscedasticity for public sector enterprises under regression 2 } \\
\text { (ZPRED \& ZRESID) }\end{array}$ & 233 \\
\hline 32 & $\begin{array}{l}\text { Test of linearity for public sector enterprises under regression 2 } \\
\text { (ZPRED vs value creation) }\end{array}$ & 234 \\
\hline 33 & Test for autocorrelation among public sector enterprises under regression 2 & 235 \\
\hline 34 & Proposed framework & 255 \\
\hline 35 & Onion diagram of stakeholders & 257 \\
\hline 36 & Power/ Interest matrix & 258 \\
\hline 37 & Designing CSR requirements and acceptance & 258 \\
\hline 38 & Eliciting CSR requirements & 259 \\
\hline
\end{tabular}




\section{CHAPTER 1}

INTRODUCTION TO CORPORATE SOCIAL RESPONSIBILITY

\subsection{Background of the study}

“Approximately 1,222 million people ( $20.75 \%$ of the world population) live on less than \$1.25 a day“(World Bank 2013). “Of the world's 736 million extreme poor in 2015, 368 million - half of the total-lived in just 5 countries. The 5 countries with the highest number of extreme poor are (in descending order): India, Nigeria, Democratic Republic of Congo, Ethiopia, and Bangladesh" (World Bank 2019a). Although the number of extremely poor has reduced by more than 721 million during the period 1981 to 2010 , the number of children living in poverty was roughly estimated to be 400 million during the year 2010" (World Bank 2013). It is also estimated that "approximately 870 million people, which is one in eight of the population worldwide, did not consume adequate amount of food on a regular basis in order to meet the minimum dietary energy requirements during the period from 2010 to 2012" (United Nations 2013). Moreover, "a vast majority of the population is also under-nourished. The under-nourished population amount to 820 million, reside in developing countries" (United Nations 2013).

During early 1990s, the World Bank defined absolute poverty line as daily earning of $\$ 1$ In 1993 , this was revised to $\$ 1.08$ a day for all countries based on Purchasing Power Parity (PPP), after adjusting for inflation. This was further revised in 2005, to US\$1.25 per day based on cost of living across the world (Ravallion et al. 2008). In October 2015, the World Bank updated the international poverty line to $\$ 1.90$ a day (World Bank 2016). The government of India estimates that $22 \%$ of its population (approximately 269.78 million) is below its official poverty line (RBI 2013). The percentage of poverty among the scheduled tribe is $43 \%$ ( 46.4 million) whereas the percentage of poverty among scheduled caste is $29.4 \%$ (73.8 million), other backward communities (including muslims) is $20.7 \%$ (108.5 million), and forward 
communities is $12.5 \%$ (49.1 million) out of a population of 1276.267 million (Minority Affairs 2006). The tribals, dalits, labourers and casual workers belong to the category of poor. Most of the tribals live in the eastern regions of India- Chhattisgarh, Bihar, Jharkhand, Odisha, Madhya Pradesh, Uttarakhand and Uttar Pradesh, and depend on agriculture for their livelihood. These regions are prone to natural calamities such as flood, cyclone and landslide. According to Rangarajan committee, the number of poor in India stood at 363 million in 2011-2012 compared to 454 million during 20092010 (Firstpost 2014). The Rangarajan panel states that 'a person is considered poor in cities if he/she is spending less than Rupees 1407 a month [INR47 (\$0.78) per day], and in villages those spending less than Rupees 972 a month [INR32 (\$0.53) per day]' (Firstpost 2014).

While the above paragraph indicates poverty among developing nations, it may be observed that transnational corporations have become powerful economic entities in creating wealth. Upon evaluating the top one-hundred economic entities (as measured by gross domestic product for nation states and sales turnover for the corporate sector), sixty are nation states and forty are multinational corporations (United Nations 2012, CNN Money 2012). Therefore, there is a need for the corporate sector to contribute resources to partner with development agencies, and help solve poverty crisis, create livelihood and enhance the standard of living in developing and least developed nations. More so, when the national and provincial governments in these countries have not been able to deliver the developmental packages satisfactorily (Malan 2005).

It has been estimated by United Nations that the transnational corporations have doubled from 37,000 in 1990 to 77,000 in 2004, with some 770,000 foreign affiliates and millions of suppliers and distributors operating along their global value chain. These affiliates generated about $\$ 4.5$ trillion in value added, employed 62 million people, exported goods and services valued at higher than $\$ 4$ trillion (UNCTAD 2007). This process has conferred new rights and created new opportunities for 
multinational corporations and large national enterprises, while at the same time, it also exposed the weak governance structures in them. The pressure caused by the competition and high risk factors created demand for benchmarks in business transparency, corporate responsibility and accountability. Corporate social responsibility has gained recognition in recent times. Human rights abuses, environmental and labour issues have brought CSR to the forefront in the developing countries. CSR is now widely discussed with reference to the context of labour, environment and human rights issues which are external to the company, particularly those issues that are taking place in the developing countries. CSR was seen as a voluntary action the businesses take in order to address these issues.

\subsection{Objectives of the study}

\subsubsection{General objective}

To evaluate corporate sustainability and strategic CSR initiatives on market value creation for firms operating in India.

\subsubsection{Specific objectives}

The specific objectives of the study are as follows:

To evaluate the corporate sustainability and CSR initiatives of multinational companies, private sector and public sector enterprises operating in India.

- $\quad$ To study as to how the dimensions of strategic CSR among multinational companies, private sector and public sector enterprises create market value for the firms operating in India.

To study as to how corporate responsibilities among multinational companies, private sector and public sector enterprises create market value for the firms operating in India. 


\subsection{Research questions}

i) What are the corporate sustainability and CSR initiatives practiced by multinational companies, private sector and public sector enterprises operating in India?

ii) How do the five dimensions of strategic CSR namely centrality, specificity, proactivity, voluntarism and visibility create market value for firms operating in India?

iii) How do the seven corporate responsibilities (i.e., Carroll's pyramid of CSR- economic responsibility, legal responsibility, ethical responsibility and philanthropy), charity and stewardship, and environmental friendliness create market value for firms operating in India?

\subsection{Significance of the study}

Although there are several studies in the western countries on CSR, there is still a lack of properly conducted study in India after the initiation of the government's policy of $2 \%$ allocation of funds in the CSR program in India. There are significant amounts of studies related to CSR in MNCs but only a few from the perspective of private sector and public sector enterprises. Thus, the present study is unique since it compares corporate sustainability and strategic CSR activities of MNCs, private and public sector companies operating in India. There has been significant research to evaluate if CSR contributes benefits to the organization in addition to contributing to the social good. The study aims to assess situations in which a firm creates value through CSR contribution among companies in India, specifically compares market value creation among international companies, private and public sector enterprises. 


\subsection{Scope of the study}

The scope of the study involves corporate sustainability and strategic CSR initiatives undertaken by corporate sector in India and includes multinational companies, private sector and public sector enterprises operating in India. The study is both qualitative and quantitative; the qualitative study is practice oriented research on corporate sustainability and CSR initiatives among clusters of companies. The quantitative study analyzes as to how five dimensions of strategic CSR-centrality, specificity, proactivity, visibility and voluntarism (Burke \& Logsdon 1996) influences market value creation; and four corporate responsibilities: pyramid of CSReconomic responsibility, legal responsibility, ethical responsibility and philanthropy (Carroll 1991); the three components of CSR - principles of charity and stewardship (Lawrence, Weber \& Post 2005); and environmental friendliness create market value for companies operating in India.

\subsection{Why India has been chosen for the study?}

The World Economic Forum Global Competitiveness Report 2012-2013 has expressed concerns regarding the performance of India in both areas of social and environmental sustainability. "India reported a poor performance rating among the BRICS countries in the 2014 Global Innovation Index" (Srinivasan 2014). The Global Innovation Index (GII) survey was done using 81 indicators among 143 nations. While all the other emerging nations have improved their ranking, India has slipped to the $76^{\text {th }}$ position, and occupies 10 places below the previous year ranking whereas Russia has improved its ranking by 13 positions reaching the 49th position over the last year (Srinivasan 2014).

'The higher education system in India is focused towards a few professional areas such as medicine, engineering and management, whereas humanities and arts have been neglected by policy makers. Research is concentrated in autonomous institutions and private sectors rather than universities. The challenges are in building 
an excellent liberal arts university infrastructure and enable research accessible to universities (Srinivasan 2014). The cultural diversity and complexity of India makes it challenging to offer some of the basic services to many of its citizens. For example, only $34 \%$ of the population has access to sanitation. Caste-ism is another social issue which is prevalent in India despite all efforts to eradicate social discrimination. Although the dalits have converted themselves from hinduism to christianity, islam, sikhism in order to escape the caste bondage of hinduism; this conversion did not make much difference in their lives. Caste has rather infected these egalitarian religions in India, thus keeping its dalits at the lowest rungs on the social ladder. In objective terms, not much has changed for the converts. "While they continue to remain dalits in the eyes of others, among themselves they appear to follow the same cultural paradigm of the hindu framework, although with some cosmetic changes" (Sikand 2011).

The employment opportunity for much of the Indian population is susceptible to risk, which, when combined with weak official social safety nets, makes the country vulnerable to economic shocks. Although no official data are reported for youth unemployment, numerous studies indicate that this percentage is very high. 'The Times of India' dated 2nd July 2014 reports that the Census 2011 released reflects an unemployment rate of more than $20 \%$ of youth in the age group 15 to 24 years. In absolute terms, this amounts to 47 million youths in the age group 15 to 24 years.

In the 25 to 29 -year age group, the unemployment rate is $18 \%$, numbering 36 million and among the 30-34-year age group, the unemployment rate is 6\% numbering 12 million. The unemployment rate among the working-age group in the range 15-59 years, is very high which is $14.5 \%$; and this also includes marginal workers seeking work (Varma 2014). If one analyzes the unemployment rate among the marginalized section of the Indian society (dalits and adivasis), the unemployment among the dalits aged $15-59$ years stands at $18 \%$ and that of the adivasis at more than $19 \%$ respectively (Varma 2014). 
On considering the competitiveness of environmental sustainability in India, this is an areas of concern, mainly due to significant air pollution and high agricultural water intensity" (WEF 2012). "India's rivers and streams suffer from high levels of pollution from waste generated primarily from industrial processes and municipal activities. The pollution generated by non-industrial waste and untreated sewage is about four times more than that of the industrial effluents. It is estimated that $75 \%$ of waste water is generated from municipal sources; industrial waste from large and medium size plants contributes to over $50 \%$ of the pollution load. Chemical and engineering industries are the major contributors of air, water and waste pollution" (Mazur 2006). Environmental issue in India is a concern due to rapid industrialization and urbanization. New Delhi, Mumbai, Chennai and Kolkata are among the most polluted cities in the world. Indian cities are overcrowded, and 39 Indian cities have a population of over one million each. Mumbai and Delhi together have a population in excess of 10 million. There are 388 smaller cities with population in excess of 100,000 and 2,483 cities with population in excess of 10,000 (World Population Prospects 2017). Therefore, the research attempts to evaluate the perception and construct validity of the environmental friendliness along with dimensions and responsibilities of CSR.

In India, even the region-wise differences in development are profound; and now that approximately one-third of the Indian land mass is influenced by the communist guerrilla group called 'naxalite', which are manifestations of economic marginalization). In this context, corporate social initiatives (CSR) would make clear impact and will be appreciated extensively (Bhattacharyya \& Sahay 2007).

The February 2011 issue of 'The Economic Times' published a detailed section regarding proposed new disclosure requirements for CSR by the Indian companies. It was indicated that a company having a net worth of Indian rupees 500 crores $\$ \$ 2.59$ million) or more during a year should formulate a CSR policy. The report also indicated that $2 \%$ of CSR spending should be implemented by private firms in India. 
The government of India replaced the 'Companies Act 1956' by the 'Companies Bill 2012' passed in the Parliament on $18^{\text {th }}$ December 2012. The Clause 135 (Bill No. 121 C of 2011 under Chapter IX - Accounts of Companies, page 80) of the Companies Bill 2012 includes corporate social responsibility. It states that "any (local and/or listed) company valued at a net worth of INR500 crores ( $\$ 82.59$ million) or more or an annual sales turnover of INR1,000 crores (\$165.18 million) or a net profit of INR5 crores $(\$ 825,900)$ or more during any financial year shall constitute a committee for CSR activity" (Ministry of Corporate Affairs 2012).

More so, 'the CSR committee shall consist of three or more directors as board members of the company, of which one will be an independent director (in the case of private companies, independent director is not required whereas two directors for CSR committee are required if there are two directors on board). The board of directors shall review the recommendation made by the CSR committee and approve CSR policies, disclose the contents of the policy in the company's report/website and ensure that the company shall spend at least $2 \%$ of the average net profit made during the three immediate financial years on CSR activities' (Ministry of Corporate Affairs 2012).

The CSR policies stated in section 135 of the Companies Bill 2012 are mentioned below:

- $\quad$ "Eradicating hunger and poverty

- $\quad$ Building educational infrastructure, gender equality and empowering women

- $\quad$ Health: in terms of improving maternal health, reducing infant mortality, preventing HIV- AIDS, malaria and other diseases

- $\quad$ Employment enabling vocational skill 
- $\quad$ Contributing to prime minister's relief fund or any other fund set up by the central government or the state government for socioeconomic welfare; and relief fund for the welfare of schedule castes /schedule tribes, other backward classes, minorities and women

Ensuring environmental sustainability

Social business projects; and

Other such matters as may be recommended from time to time" (Ministry of Corporate Affairs 2012).

The company shall disclose the composition of CSR committee, CSR policy and initiatives, the amount of expenditure incurred on CSR activities and the reason for failure to spend the earmarked CSR budget. The government is likely to make CSR attractive by offering tax deductions and benefits to companies that implement CSR activities. It has been estimated that an approximately 2,500 enterprises would fall in this 'mandatory' CSR disclosure category. This is expected to mobilize an amount of INR9,000 crores ( $\$ 1.486$ billion) to INR10,000 crores (\$1.652 billion) towards social welfare (Ministry of Corporate Affairs 2012).

A study undertaken by an industry body during june 2009 involving CSR activities of 300 corporate houses in India reported that $36 \%$ of the CSR activities are concentrated in Maharashtra state, followed by $12 \%$ in Gujarat, $10 \%$ in Delhi and $9 \%$ Tamil Nadu. The companies have on an aggregate identified 26 different areas of development activities undertaken under this initiative. It was reported that community welfare was the most prominent among them all, followed by education, environment, health, and rural development (IBEF 2010).

A report published in Business Ethics (2010) state that " $67 \%$ of India's domestic companies have chosen non-government organizations as partners in order to undertake their corporate social responsibility projects, while $58 \%$ preferred 
government department for the spread of CSR obligations," as confirmed by a survey undertaken by the chamber of commerce- Associated Chambers of Commerce and Industry of India (ASSOCHAM). However, only $8 \%$ of the companies reported their CSR activities in their annual reports and this was comparatively lesser than the CSR activities reported by international firms.

1.7 Reason for studying dimensions of strategic CSR \& corporate responsibilities

Aupperle et al. (1983) developed an instrument using Carroll's four-part corporate responsibility model. Aupperle et al. (1983) has mentioned his study that "though there has been an enormous body of literature emerging around the concept of corporate social responsibility (CSR), actual empirical research designed to test the multitude of definitions, propositions, concepts and theories has been scarce. This is partially due to the large number of perspectives on viewing the CSR notion, thus resulting in no generally accepted definitions. It is also due to the difficulty in developing valid measures of CSR. Indeed, the vagaries involved in assessing CSR are substantial in comparison to the assessment of economic and financial performance" (Aupperle et al. 1983). 


\subsection{ORGANIZATION OF REST OF THE THESIS}

Chapter 2 CONCEPTS \& THEORIES ON CSR

The second chapter deals with review of literature. This chapter provides an insight into definitions and history of CSR, dimensions of strategic CSR, strategy linked to CSR, and Carroll's pyramid of responsibilities. This chapter includes empirical studies as well as theoretical viewpoints on CSR, CSR guidelines and some of the reasons for catalyzing CSR.

\section{Chapter 3 IMPORTANCE OF STRATEGIC CSR IN CREATING STAKEHOLDER VALUE}

The third chapter deals with CSR value chain and context of competitiveness, role of CSR in improving competitiveness of the firm, benefits of CSR to the organization, CSR and business value, CSR in emerging markets, factors contributing to CSR in emerging markets, areas of CSR activities, hypotheses and its rationale.

\section{Chapter 4 RESEARCH METHODOLOGY}

The fourth chapter outlines research strategy, research design, methods used in data collection, sampling techniques followed by method of analyses and the justification for employing a particular research approach to achieve the objectives of the study. The research employs both qualitative and quantitative methods. This chapter also provides information on variables, brief information on steps followed and a comparison of current methodology with that of previous similar studies conducted.

Chapter 5 CORPORATE SUSTAINABILITY \& CSR INITIATIVES IN THE INDIAN CORPORATE SECTOR (Qualitative study)

The fifth chapter highlights definitions and dimensions of corporate sustainability, integration of corporate sustainability in business organizations. It provides descriptive approach on corporate sustainability \& CSR initiatives undertaken in 
multinational companies, private sector and public sector enterprises in India. The information has been gathered based on researcher's experience in the industry and through one to one discussion with CSR managers of various corporations, sustainability reports, CSR reports and annual reports of the companies. 43 companies (multinationals, Indian private and public sector enterprises) implementing CSR are included in this qualitative study. Thematic analyses is undertaken, important themes identified and compared among the three clusters of organizations under study.

Chapter 6 DIMENSIONS OF STRATEGIC CSR \& RESPONSIBILITIES OF COMPANIES OPERATING IN INDIA (Quantitative study)

The sixth chapter provides detailed information on descriptive statistics, correlation analysis, regression analysis 1, factor analysis, and regression analysis 2 with focus on quantitative study on dimensions of strategic CSR, responsibilities of companies

operating in India. Number of companies included in the quantitative study are 93 selected among multinationals, Indian private and public sector enterprises implementing CSR.

\section{Chapter 7 CONCLUSIONS}

The concluding chapter summarizes findings of the research followed by recommendations for future research, implications and limitations. 


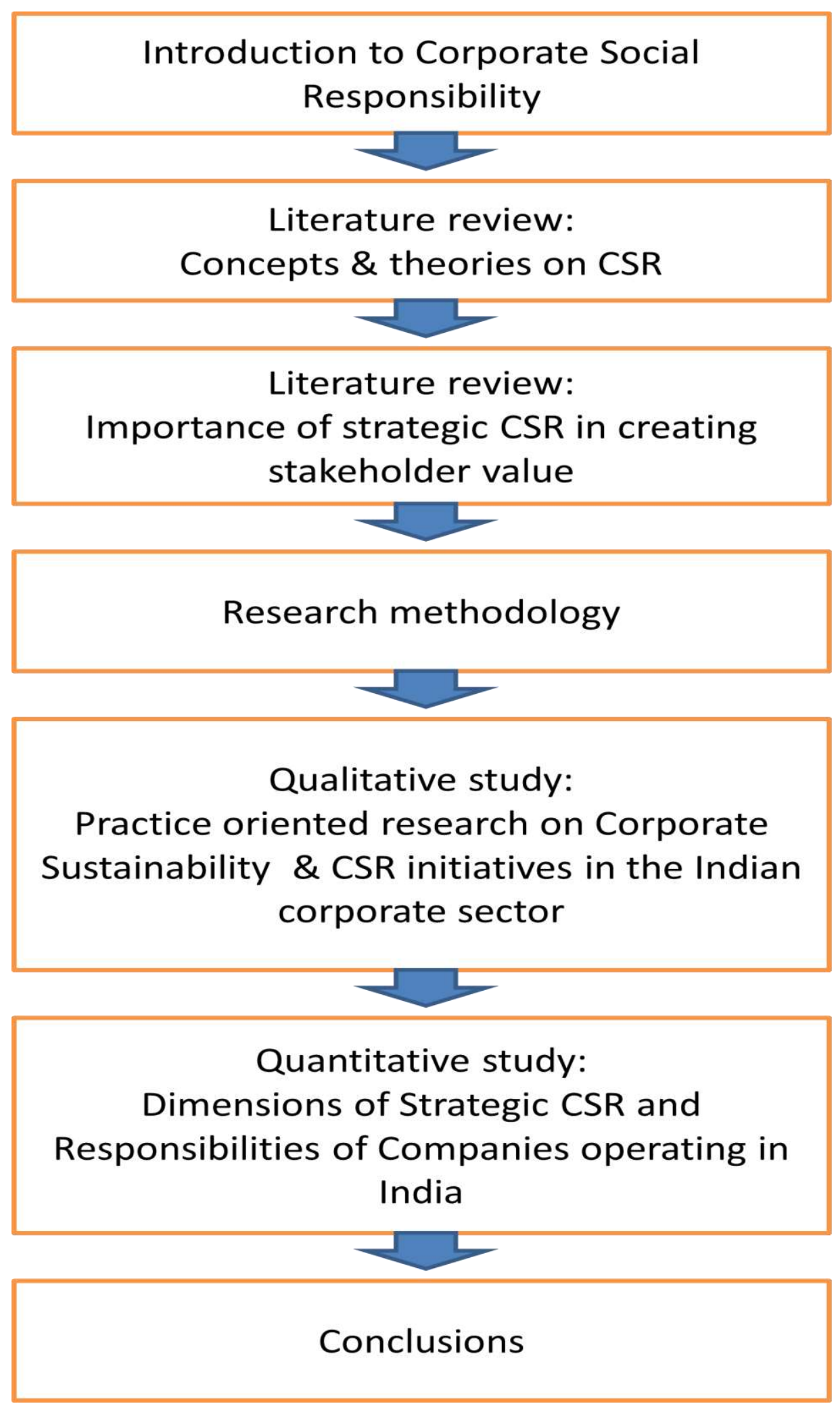

Figure 1: Organization of the thesis 


\section{CHAPTER 2}

\section{CONCEPTS \& THEORIES OF CSR}

\subsection{Definitions of CSR}

Corporate social responsibility (CSR) has been defined in several ways (Wood 1991, Garriga \& Melé 2004) as given in the table 1. However, almost all definitions share the view point that CSR is based on principles of "actions that appear to further some social good which is beyond the interests of the organization, and are required by the law" (McWilliams \& Siegel 2001, 117). According to the World Business Council for Sustainable Development, corporate social responsibility is defined as "the commitment of business to contribute to sustainable economic development, working with employees, their families, the local community and the society at large, to improve their quality of life" (WBCSD 2002).

Table 1: Definitions of corporate social responsibility

\begin{tabular}{l} 
'The obligations of businessmen to pursue those policies, to make those \\
decisions, or to follow those lines of action which are desirable in terms of \\
objectives and values of our society' (Bowen 1953,6$)$ \\
'Businessmen's decisions and actions taken for reasons at least partially \\
beyond the firm's direct economic and technical interest' (Davis 1960,70) \\
'Is the pursuit of socioeconomic goals through elaboration of social norms in \\
prescribed business roles; or, to put it more simply, business takes place within \\
particular ways of responding to particular situations and sets out in some \\
detail the prescribed ways of conducting business affairs' (Johnson 1971,51) \\
\hline [Means] 'a condition in which the corporation is at least in some measure a \\
free agent. To the extent that any of the foregoing social objectives are \\
imposed on the corporation by law, the corporation exercises no responsibility
\end{tabular}


when it implements them' (Manne \& Wallich 1972, 40)

'Encompasses the economic, legal, ethical, and discretionary expectations that society has of organizations at a given point in time' (Carroll 1979, 500)

'To turn a social problem into economic opportunity and economic benefit, into productive capacity, into human competence, into well-paid jobs, and into wealth' (Drucker 1984, 62)

'Relates primarily to achieving outcomes from organizational decisions concerning specific issues or problems which (by some normative standard) have beneficial rather than adverse effects on pertinent corporate stakeholders' (Epstein 1987, 107)

'Is concerned with the ways in which an organization exceeds the minimum obligation to stakeholders specified through regulation and corporate governance' (Johnson \& Scholes 2002, 247)

'Is a commitment to improve community well-being through discretionary business practices and contributions of corporate resources' (Kotler \& Lee 2005, 3)

\subsection{History of corporate social responsibility}

The first book on social behavior of corporations, namely "Social responsibilities of businessman" was written by Howard R Bowen in 1953 (Garriga \& Melé 2004). Bowen believed that "businessmen should contribute to the society in terms of support that generates value" (Carroll 1999). Bowen's (1953) book was used as a rationale by scholars who observed societal issues during the 1960 s and early 1970 s. It was Theodore Levitt, who in 1958 first introduced the term "Corporate Social Responsibility" (McWilliams et al. 2006). McGuire's (1963) book "Business and society" laid emphasis on rationale for role of social responsibilities for business. McGuire (1969) laid emphasis on four approaches to CSR - traditional, enlightened, responsible and confused. These viewpoints are discussed as follows: McGuire's 
(1969) traditional approach points out a neoclassical economic view of CSR stating that CSR has no role in business. The enlightened view highlight that CSR serves the corporate self-interest; the responsible view suggests that CSR may or may not pay, but it is the right thing to do. The confused view point suggests that CSR is ethical and expects to pay off for the organization (McGuire 1969). Subsequent years have witnessed a large number of books on social responsibility by academicians and authors.

Although a large number of literatures concerning the above topic exist, no uniform definition has been established. The issue primarily lies in the nature of concepts related to CSR, which are concerned with morality and business ethics. According to Crane and Matten (2004), "morality refers to beliefs and values acquired by the society, and the actions which are considered right or wrong in the society as a whole. Ethics is the study of morality and those rules which determine the values of the society." Dahlsrud (2006) suggests that "confusion exists regarding application of CSR in a society under a specific context." Furthermore, "organizations across countries display varying degrees of commitments in order to appear socially responsible, and they use their own means to communicate this socially responsible image" (Maignan \& Ralston 2002). According to Levitt, "the responsibility of government is to provide safety and security to its citizens, whereas the responsibility of business is to create wealth." Therefore, business is not required to intervene in the functioning of the government.

Later, Friedman (1970) added to this discussion stating that CSR would create an internal agency problem, implying that an engagement in CSR was seen as a waste of company resources. Friedman believed that the best way to support the society was to create wealth and profits; and by utilizing resources efficiently on projects that add value. During the 1980 s, with a wider viewpoint in the area of CSR, the stakeholder theory focused on importance of stakeholders in creating a successful business. It states "individuals or groups related to an organization are considered to 
be stakeholders of the organization" (Donaldson \& Preston 1995). The organizations should consider all the affected parties (Post, Preston \& Sachs 2002). Stakeholders are classified as internal (e.g.: employees, stockholders) and external (e.g.: suppliers, local communities and consumers), and the actions of key stakeholders may impact businesses in several ways (McWilliams et al. 2006). Since the level of corporate social performance is dependent on a constant interplay between an organization and its stakeholders (Griffin 2000); the managers' focus should shift away from primarily satisfying stockholders, and move toward satisfying the needs of important stakeholders. Also, in situations with strict regulations, companies are more likely to act in a socially responsible manner when such regulations are based on negotiations with related stakeholders (Campbell 2007).

The global issues due to climate change and natural disasters have resulted in prominence of natural environment becoming a part of discussion among several organizations (Norton 2007). For example, companies could invest in sustainable development, meaning "adequate developments which ensure future generations to meet their needs" (Wheeler, Colbert \& Freeman 2003). An organization engaged in CSR projects is capable of generating support and goodwill from the stakeholders. The slack resources theory states that "organizations generating low profits would find it difficult to undertake CSR activities compared to that of successful organizations that generate sustained profits" (McWilliams \& Siegel 2001). Therefore, an organization could invest in social projects only if it has a long term goal and vision with regard to environmental sustainability.

\subsection{Dimensions of strategic CSR}

The current study attempts to assess relationship between dimensions of strategic CSR programme with value creation. Hence, the researcher adopted strategic dimensions developed and validated by Burke \& Logsdon (1996) that include 
'centrality, specificity or appropriability, proactivity, visibility and voluntarism' (Burke \& Logsdon 1996) as shown in figure 2 below.

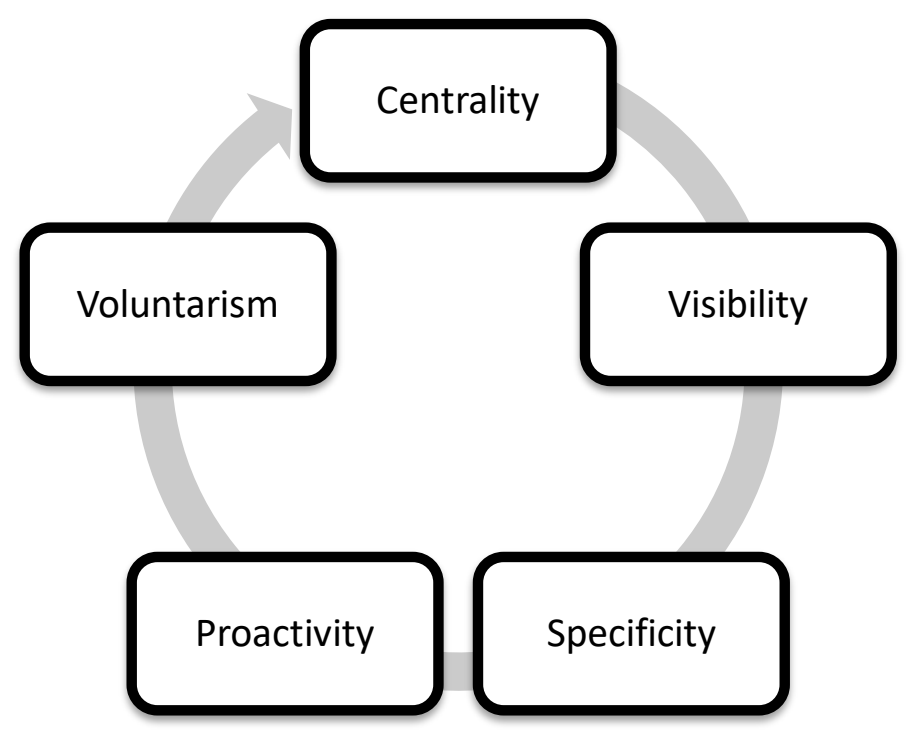

Figure 2: Dimensions of strategic CSR (Source: Burke \& Logsdon 1996)

These dimensions are tested among multinational companies, private sector companies and public sector enterprises in India. The research also highlights importance of these results for strategic management of CSR and makes suggestions for future research.

Table 2: Dimensions of strategic CSR (Source: Burke \& Logsdon 1996)

\begin{tabular}{|l|l|}
\hline Dimensions & Description \\
\hline Centrality & $\begin{array}{l}\text { According to Ansoff, and Thorelli, the initiatives of CSR } \\
\text { should be related to the mission and objectives of the firm } \\
\text { (Ansoff 1997, 1983; Thorelli 1997). The closeness of CSR } \\
\text { initiative to the vision and mission of the company helps the } \\
\text { management organize and deliver CSR activities. This } \\
\text { management action generates positive impact and profits } \\
\text { for the company }\end{array}$ \\
\hline
\end{tabular}




\begin{tabular}{|c|c|}
\hline $\begin{array}{l}\text { Specificity or } \\
\text { Appropriability }\end{array}$ & $\begin{array}{l}\text { The initiatives of CSR are expected to provide specific } \\
\text { benefits to the firm. These specific benefits of CSR } \\
\text { programmes are undertaken over a time period, and the } \\
\text { company should be able to utilize these specific benefits in } \\
\text { its favour. This helps the company strategically rather than } \\
\text { making goods and services. Strategic CSR is expected to } \\
\text { benefits the company as the company achieves competitive } \\
\text { position by focusing on cost advantage and differentiation } \\
\text { (Hunt } 2000, \text { Miles \& Covin } 2000, \text { Karna } 2003, \text { Day \& } \\
\text { Wensley } 1988, \text { Rumelt } 1980, \text { Porter } 1985, \text { Crawford \& } \\
\text { Scaletta 2005). } \\
\text { According to Burke \&Logsdon, specificity is the ability of the } \\
\text { firm to connect between the financial benefits and the } \\
\text { social objectives (Burke \& Logsdon 1996). }\end{array}$ \\
\hline Proactivity & $\begin{array}{l}\text { The strategic CSR initiatives should be capable of } \\
\text { determining the changing expectations of the stakeholder. } \\
\text { This is to understand the changing environment of business } \\
\text { (social, environmental, political and technological } \\
\text { developments) taking place in the system. Strategic CSR } \\
\text { initiatives are to be planned (Quinn 1980) when there is no } \\
\text { crisis within the organization. }\end{array}$ \\
\hline $\begin{array}{l}\text { Voluntarism } \\
\text { (Volunteerism) }\end{array}$ & $\begin{array}{l}\text { The decision making process of strategic CSR is based on } \\
\text { judgment and freedom of the organization. Lyle as well as } \\
\text { Burke suggests that, "strategic CSR is a discretionary } \\
\text { decision making process" (Lyles 1985, Burke et al. 1986). } \\
\text { According to Carroll (1979), CSR, by definition is said to be } \\
\text { discretionary in nature. Thus, voluntarism and proactivity } \\
\text { has a link through this definition. }\end{array}$ \\
\hline
\end{tabular}




\begin{tabular}{|c|c|}
\hline Visibility & $\begin{array}{l}\text { Visibility refers to the ability of being observed. In order to } \\
\text { gain recognition from all the stakeholders, strategic CSR } \\
\text { should be undertaken through a visible process (Mintzberg } \\
\text { 1988). } \\
\text { Strategic CSR initiative is capable of building an image for an } \\
\text { organization by communicating its activities in the media or } \\
\text { the press. The positive feelings generated in this way could } \\
\text { overcome the previously generated negative feelings, if } \\
\text { applicable. The positive effect could offer some protection } \\
\text { to the organization in terms of regulation or investigation. }\end{array}$ \\
\hline
\end{tabular}

The characteristics of strategic CSR over CSR is that strategic CSR obeys five fundamental principles laid down by Burke \& Logsdon (1996) which are:

- CSR activity should be close to the mission of the firm.

- CSR activity should achieve cost advantage and product or service differentiation for the firm.

- It predicts and understands the expectations of stakeholders, willingness and freedom on the part of the company, and build image of the company.

According to Burke \& Logsdon (1996), firms create market value through business activities by investing in new technologies, creating new products, through brand awareness, through processes such as production facilities, training and customer service. In the tables $3 \& 4$, Burke \& Logsdon (1996) highlights as to how strategy is linked to CSR; and that CSR behaviours of firms (philanthropic contribution, employee benefits, and environmental management, political activities and product or service related characteristics, innovation or processes) influence the dimensions of strategic CSR leading to value creation for the firms. 
Table 3: Strategy linked to CSR and outcome (Source: Burke \& Logsdon 1996)

\begin{tabular}{|c|c|c|}
\hline $\begin{array}{l}\text { Definition of } \\
\text { strategy }\end{array}$ & Dimensions of CSR & Outcome \\
\hline $\begin{array}{l}\text { Goals, mission, } \\
\text { objectives (Ansoff, } \\
\text { Andrews, Thorelli) }\end{array}$ & $\begin{array}{l}\text { Centrality: } \\
\text { Closeness of fit to the main } \\
\text { objectives of the firm }\end{array}$ & \multirow{5}{*}{$\begin{array}{l}\text { Value } \\
\text { creation: } \\
\text { Identifiable, } \\
\text { measurable, } \\
\text { economic } \\
\text { benefits that } \\
\text { the firm } \\
\text { expects to } \\
\text { receive }\end{array}$} \\
\hline $\begin{array}{l}\text { Competitive } \\
\text { advantage } \\
\text { (Rumelt, Porter) }\end{array}$ & $\begin{array}{l}\text { Specificity: } \\
\text { Ability to capture benefits by the } \\
\text { firm }\end{array}$ & \\
\hline Plan (Quinn) & $\begin{array}{l}\text { Proactivity: } \\
\text { Degree to which the programme is } \\
\text { planned in anticipation of emerging } \\
\text { social trends and in the absence of } \\
\text { crisis situations }\end{array}$ & \\
\hline Process (Lyles) & $\begin{array}{l}\text { Voluntarism: } \\
\text { The scope of discretionary decision } \\
\text { making and the lack of externally } \\
\text { imposed compliance requirements }\end{array}$ & \\
\hline $\begin{array}{l}\text { Pattern } \\
\text { (Mintzberg) }\end{array}$ & $\begin{array}{l}\text { Visibility: } \\
\text { Observable, recognizable credit by } \\
\text { internal and/or external } \\
\text { stakeholders for the firm }\end{array}$ & \\
\hline
\end{tabular}


Table 4: Strategic benefits from socially responsible behavior (Source: Burke \& Logsdon 1996)

\begin{tabular}{|c|c|c|c|c|c|c|}
\hline CSR behaviour & Centrality & Specificity & Proactivity & Voluntarism & Visibility & Value creation \\
\hline $\begin{array}{l}\text { Philanthropic } \\
\text { contribution } \\
\text { (cash, product, } \\
\text { time) }\end{array}$ & $\begin{array}{l}\text { Computer } \\
\text { manufacturer } \\
\text { donating } \\
\text { computers to } \\
\text { schools; } \\
\text { Engineering } \\
\text { research } \\
\text { fellowships }\end{array}$ & $\begin{array}{l}\text { Getting new users to } \\
\text { try firms' products } \\
\text { versus the } \\
\text { competitors' }\end{array}$ & & $\begin{array}{l}\text { Community } \\
\text { support }\end{array}$ & & $\begin{array}{l}\text { Customer } \\
\text { loyalty } \\
\text { Future } \\
\text { purchases }\end{array}$ \\
\hline $\begin{array}{l}\text { Employee } \\
\text { benefits (direct } \\
\text { or indirect) }\end{array}$ & & $\begin{array}{l}\text { Health, wellness, } \\
\text { day care \& flexitime }\end{array}$ & $\begin{array}{l}\text { New or } \\
\text { uncommon } \\
\text { benefits; } \\
\text { Enhanced } \\
\text { employee } \\
\text { loyalty }\end{array}$ & $\begin{array}{l}\text { Employee } \\
\text { loyalty and } \\
\text { morale }\end{array}$ & $\begin{array}{l}\text { Internal } \\
\text { employee } \\
\text { loyalty and } \\
\text { morale }\end{array}$ & $\begin{array}{l}\text { Gains in terms } \\
\text { of productivity }\end{array}$ \\
\hline
\end{tabular}




\begin{tabular}{|c|c|c|c|c|c|c|}
\hline $\begin{array}{l}\text { Environmental } \\
\text { management } \\
\text { (health, safety, } \\
\text { environment) }\end{array}$ & $\begin{array}{l}\text { New products, } \\
\text { green products, } \\
\text { process innovation } \\
\text { \& pollution control }\end{array}$ & $\begin{array}{l}\text { Innovation or } \\
\text { patent, } \\
\text { Advantages over } \\
\text { competition in } \\
\text { product or process } \\
\text { development }\end{array}$ & $\begin{array}{l}\text { Learning curve } \\
\text { advantages }\end{array}$ & $\begin{array}{l}\text { Positive } \\
\text { relationship } \\
\text { with } \\
\text { regulators }\end{array}$ & $\begin{array}{l}\text { Public } \\
\text { relations } \\
\text { and/or } \\
\text { marketing } \\
\text { advantage }\end{array}$ & $\begin{array}{l}\text { New products } \\
\text { or new } \\
\text { markets }\end{array}$ \\
\hline $\begin{array}{l}\text { Political activity } \\
\text { (lobby, } \\
\text { information) }\end{array}$ & $\begin{array}{l}\text { Favourable change } \\
\text { in economic and } \\
\text { social regulations }\end{array}$ & $\begin{array}{l}\text { New business } \\
\text { opportunities, if } \\
\text { prepositioned to } \\
\text { take advantage of } \\
\text { new rules }\end{array}$ & $\begin{array}{l}\text { Positioning for } \\
\text { changes in } \\
\text { regulations }\end{array}$ & & & $\begin{array}{l}\text { New product } \\
\text { or geographic } \\
\text { market } \\
\text { opportunities }\end{array}$ \\
\hline $\begin{array}{l}\text { Product or } \\
\text { service related } \\
\text { characteristic, } \\
\text { innovation or } \\
\text { processes }\end{array}$ & $\begin{array}{l}\text { Product } \\
\text { reformulation. Eg.: } \\
\text { Green products, } \\
\text { Improved design } \\
\text { Eg.:Fuel efficiency, } \\
\text { New products such } \\
\text { as airbags }\end{array}$ & $\begin{array}{l}\text { Patent or innovation } \\
\text { edge. } \\
\text { First-to-market. } \\
\text { Brand loyalty }\end{array}$ & $\begin{array}{l}\text { Environmental } \\
\text { scanning to } \\
\text { create edge in } \\
\text { design or } \\
\text { product ideas }\end{array}$ & & $\begin{array}{l}\text { First-to- } \\
\text { market or } \\
\text { leadership } \\
\text { benefits }\end{array}$ & $\begin{array}{l}\text { New products } \\
\text { in new } \\
\text { markets. } \\
\text { Edge in } \\
\text { meeting } \\
\text { emergency } \\
\text { needs }\end{array}$ \\
\hline
\end{tabular}




\subsection{Pyramid of CSR}

Carroll identified four divisions of corporate social responsibility, namely: "economic responsibility, legal responsibility, ethical responsibility and philanthropy" (Carroll 1991). According to Carroll $(1991,1999)$, economic responsibility refers to the need for corporations to be profitable. Legal responsibility refers to the requirements for business to operate within the boundaries of laws and national policies. Ethical responsibility demands moral behavior of the organizations whereas philanthropy obliges organizations to contribute financially and offer resources for welfare of the society and the community.

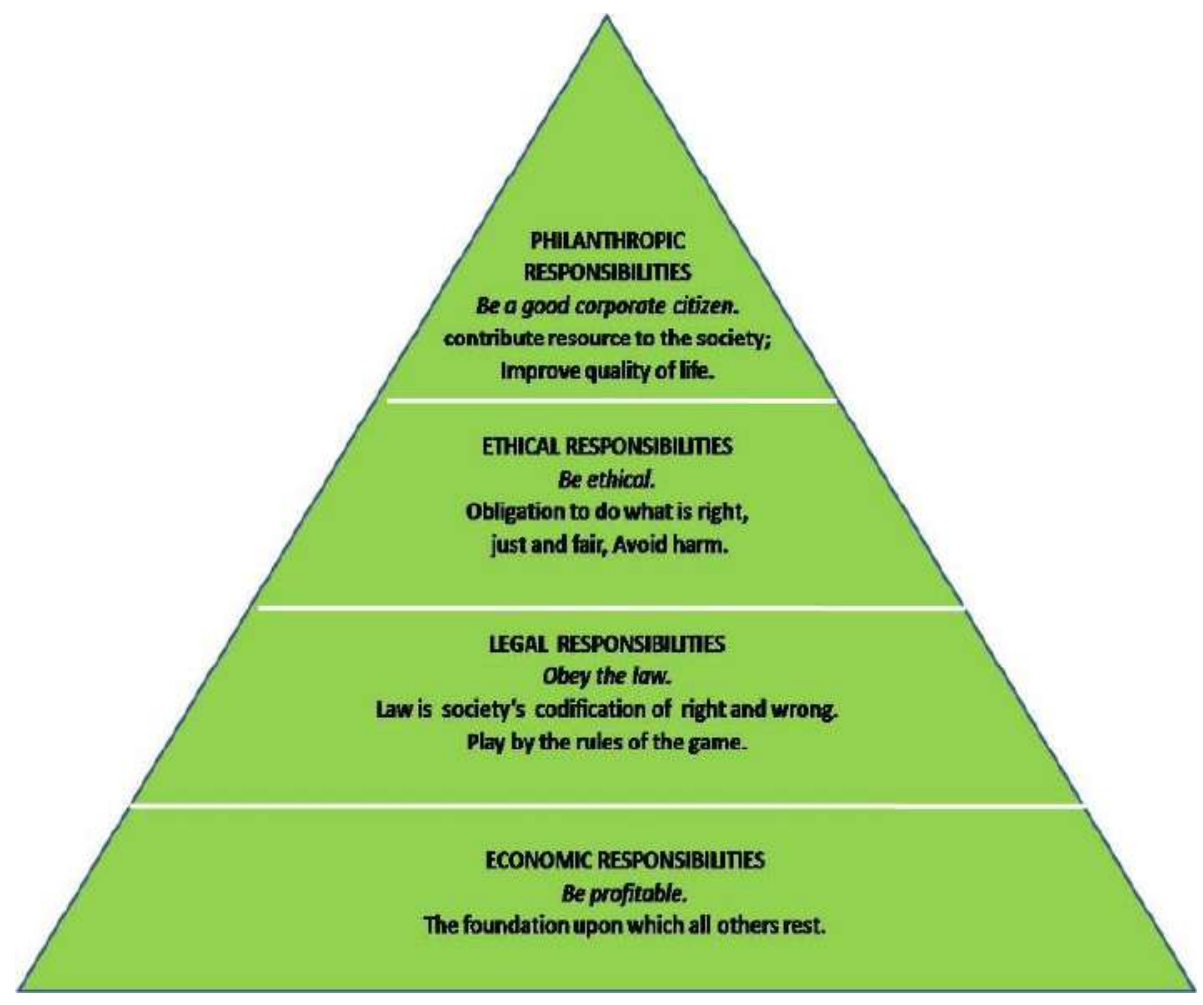

Figure 3: Pyramid of CSR (Source: Carroll 1991, 1999)

The Carroll's $(1991,1999)$ pyramid is depicted in figure 3 above. The economic responsibility is the basis on which an organization undertakes business activity, generates goods and services efficiently at an affordable price, catering to the needs 
of the customers and users of products/services. The economic responsibility refers to society's expectation that an organization will produce goods and services needed and desired by customers and sell those goods and services at a reasonable price (Asemah et al. 2013a). Organizations are expected to be efficient, profitable and keep shareholders' interests in mind. The legal responsibility refers to the expectation that an organization will comply with the laws laid down by society to govern competition in the marketplace (Asemah et al. 2013a). Societies and cultures have a major role to play in evolving social values and ethics. Ethical and cultural values have evolved over a period of times and the societies identify the type of corporate behavior which they appreciate or discourage. Complying with ethical values helps the company do things that are right, just and appropriate. The philanthropy is about giving back to the society and enhancing quality of life of the people. The society and the government encourage companies to contribute resources voluntarily towards social welfare projects. Philanthropy is undertaken at the discretion of the company and could be classified as an 'explicit' CSR and are motivated by the expectations of stakeholders (Matten \& Moon 2008). Although the philanthropy is not an ethical requirement, it has been acknowledged and appreciated by the society. It is important to note that Carroll $(1991,1999)$ points out the economic responsibility of business first and other responsibilities follow once the economic responsibility is achieved.

According to Maslow, human needs may be organized in a hierarchy in which higherlevel needs are inactive until lower-level needs are fulfilled (Sheth \& Mittal 2004). First of all, in order to survive, people should have food, clothing and shelter needs, or physical needs. After satisfying these basic needs, people encounter security and social needs which include safety and the need to belong to a certain group or to generate a high status in the society. Subsequent is the self-esteem needs and lastly self-actualization needs, motivating people to invest in self-development (Maslow 1943). 
The purpose of the 'hierarchy of needs' theory is to identify motivation levels of individuals. Tuzzolino \& Armandi (1981) found that this concept of progressing needs applies to organizations as well. The most salient organizational need is the existence or survival need. In order to exist, business has to create wealth and profits. Once a company generates adequate profits, it aims to achieve a safe business environment in order to protect its business. Once the business is protected, the company looks beyond a secured environment. It aims to achieve affiliation needs by developing and maintaining a favourable relationship with its stakeholders.

The self-actualization need in the 'hierarchy of needs' theory can be categorized as the 'philanthropy responsibility' of the company (Tuzzolino \& Armandi 1981). According to this theory, only self-actualizing companies can become socially responsible organizations since such firms have the ability to satisfy preceding compelling needs. Meeting the 'philanthropy need' enables companies to achieve its social objectives. The successful companies will be able to create a differentiation and position itself from its competitors. From the pyramid of Carroll, it may be understood that organizations are required to build economic capability on a continuous basis before gradually transforming to a socially responsible organization.

The relation between being a profitable company and a socially responsible company is mediated by regulations, institutional norms and organizations monitoring responsible corporate behaviour (Campbell 2007). Not every organization can or will invest in CSR. Only organizations that are well established, with financial capability are in a position to engage in philanthropic corporate behaviour. Thus, the theory of sequential corporate responsibilities by Carroll is supported by the earlier research of Tuzzolino \& Armandi (1981). According to Carroll (2016), "the pyramid should not be interpreted to mean that business is expected to fulfil its social responsibilities in the same sequential, hierarchical fashion, starting at the base. Rather, business is expected to fulfil all responsibilities simultaneously". Economic responsibilities + legal responsibilities + ethical responsibilities + philanthropic responsibilities $=$ Total 
Corporate Social Responsibilities (Carroll \& Buchholtz 2014). Therefore, it is appropriate to mention that economic, legal, ethical and philanthropic responsibilities create value for the firms.

\subsection{CSR related to charity and stewardship}

The CSR is also related to charitable activities that the companies carry out in order to highlight to the stakeholders and the society that they care for the poor and the needy. The corporations offer charity on a large scale reflecting an image of corporate citizenship. Charity is different from philanthropy in a way that charity is done at once with the intention of helping the needy without any motive or expectation of economic gain whereas philanthropy is strategic and has a motive of economic gain for the organization.

The dictionary meaning of 'stewardship' is "the job of supervising or taking care of something, such as an organization or property." Managers are stewards or custodians of organizational processes and resources; carry out their duties diligently, and are accountable and responsible to the stakeholders. Stewardship encourages intrinsic motivation and therefore, is directed towards achievement of organizational or societal goals.

\subsection{CSR and environmental challenges}

Rapid population and industrialization has resulted in high concentrations of carbondi-oxide in the atmosphere and anthropogenic climate change. According to World Bank, "the atmospheric carbon-di-oxide concentration has increased from 260-280 parts per million (ppm) in pre-industrial times to 391 ppm in September 2012, and global mean warming is already 0.8 - $\mathrm{C}$ above pre-industrial levels. Damage to the global environment is reaching critical levels and threatens to lead to irreversible changes in global ecosystems" (World Bank 2012). Environmental challenges facing developing countries are land degradation, desertification, floods and rising 
temperature causing destruction of crops. Climate-related natural catastrophes have a direct adverse impact on the economy causing damage to the infrastructure. According to the World Bank, the unprecedented floods in Thailand during the year 2011 have caused a loss amounting of $\$ 45$ billion to the Thailand government. China experienced one of the worst droughts in the last six decades, affecting four million farmers with the water crisis. The Guardian reported that devastating flash floods have drowned hundreds of people, displacing 100,000 people overnight in two southern Philippine cities during December 2011 (McVeigh \& De Leon 2011). Typhoon Haiyan killed over 10,000 people in the central Philippines on November 10, 2013 (Walker 2013).

According to World Economic Social Survey (2013), "the stability of global environment is under threat from human activity, owing largely to unsustainable consumption pattern that reflects extreme inequalities" (WESS 2013). The scientific community believes that the global warming is caused by human behavior, mainly by the use of fossil fuel for energy generation and to some extent by changes in land use and deforestation" (WESS 2013). Hence, there is a need for corporations to pay attention to the use of environment friendly energy sources and minimize damages to the environment.

\subsection{Empirical results from previous studies and its relevance}

Two studies were published, one by Aupperle (1983) to test the CSR model developed by Carroll (1979), and the other study conducted by Husted \& Allen (2007) to evaluate the dimensions of strategic CSR developed by Burke \& Logsdon (1996). Aupperle's (1983) study is important because it is a study based on Carroll's (1991, 1999) pyramid testing the four pillars - economic responsibility, legal responsibility, ethical responsibility and philanthropy among firms in the USA. Husted \& Allen's (2007) study is important because it is involved testing the model of Burke \& Logsdon (1996) - centrality, specificity, proactivity, voluntarism and visibility among firms in 
Spain (table 15 under chapter 4 Research methodology). The current study is a combination of Carroll's pyramid of CSR (1979), dimensions of strategic CSR by Burke \& Logsdon (1996), the three components of CSR - principles of charity and stewardship (Lawrence, Weber \& Post 2005), and environmental friendliness involving value creation by corporations; and was undertaken in 2011, prior to implementing mandatory CSR by the Government of India. India has a large population of 1.366 billion (World Population Review 2019). India is an important market and an emerging economy. There were several issues related to environmental violations, labour exploitation, and social inequality in India (as explained in Chapter 1). Moreover, the awareness of CSR among employees of corporations was low, and that majority of corporations did not practice CSR nor had a CSR policy until 2012 when CSR was made mandatory by the law. It was only in 2009 that large public sector enterprises initiated some kind of CSR activities focused towards communities living around their facilities.

\subsubsection{Study conducted by Aupperle (1983)}

The objectives of Aupperle (1983) were to develop an instrument using Carroll's (1979) four part CSR model and to test the model among a sample of executives in national firm. Aupperle (1983) identified 810 corporate executives in order to test the Carroll's (1979) conceptual model of CSR, wherein 29.5\% (241) responded. The questionnaire contained 20 sets of 4 forced choice statements, four statements in each set correspond to four components in Carroll's (1979) model. Likert scaling was done to analyze the opinion (Aupperle 1983).

The selected CSR statements were tested for validity and reliability. A blind panel of judges identified 117 CSR statements and categorized them. Cronbach's alpha for all the CSR categories reflected a coefficient of 0.83 suggesting internal consistency alpha for economic responsibility $=0.93$, legal responsibility $=0.84$, ethical responsibility $=0.84$ and philanthropy $=0.87$ (Aupperle 1983). 
Factor analysis - $\mathrm{N}$ factor analysis, principal factor analysis with varimax rotation was performed on 80 items from the 20 sets of CSR. The four factor principal factor analysis did not yield any results. However, the fifth factor had loading with economic responsibility and ethical responsibility components. It was observed that 49 out of 80 statements had loading greater than 0.40 as one of the factors. These items were distributed as follows: economic responsibility = 1 item, legal responsibility $=15$ items, ethical responsibility $=17$ items and philanthropy $=16$ items. In addition, 2 of the 4 CSR components were repeated in factor 3 with high negative loading along the economic responsibility component and high positive loading along the ethical responsibility component (Aupperle 1983).

\subsubsection{Study conducted by Husted \& Allen (2007)}

Husted \& Allen (2007) tested the model of centrality, specificity (appropriability), proactivity, visibility and voluntarism (Burke \& Logsdon, 1996) among 500 large Spanish firms with response rate of $22.0 \%$, having completed 111 surveys. Husted \& Allen (2007) performed hierarchical regression analysis among variables, performed tests to assess reliability and validity of the construct. Other tests such as heteroscedasticity and multicollinearity were undertaken. The authors stated that severity of multicollinearity needs to be tested more thoroughly. Three models were developed with control variables for appropriability, visibility and voluntarism were included in all the models. The control variables were not significant or marginally significant. It was also reported that heavy manufacturing industries showed marginal significance due to environmental issues which had greater or negative impact on value creation (Husted \& Allen 2007).

The results obtained were mixed, with some studies reporting positive relationships, other studies reporting negative relationships, and a few others showing neutral relationships; after more than two decades of research on relationship between CSR and financial performance. The researchers Husted \& Allen (2007) identified a 
positive relationship among visibility and value creation. It was also observed that greater specificity leads to greater potential for value creation. Voluntarism may either increase or decrease value creation. In addition, R-square and F-statistic increased significantly in the case of specificity, visibility and voluntarism.

\subsection{Theoretical viewpoints on corporate social responsibility}

Over the past several decades, much effort was invested by both business ethicists and management theorists on understanding the role of business towards the society (Carroll \& Buchholtz 2000) in order to formulate a viewpoint on corporate social responsibility. In fact, large differences have been reported with reference to viewpoints of business scholars and key stakeholders of corporations. According to Friedman's (1970) viewpoint, "corporation has no responsibility except making profit in a legal way" (Friedman 1970). In the 'Classical view of CSR', Friedman argued that "socially responsible activities should contribute to profit generation for the organization" (Friedman 1967, 1996).

CSR may only incur "additional cost and hence would affect the overall performance and sustainability of an organization" (Pinkston \& Carroll 1996, Henderson 2001). It was during the latter part of the twentieth century wherein several scholars argued that "a corporation has several responsibilities towards its stakeholders" (Carroll 1993, 1999; Donaldson \& Preston 1995, Freeman 1984). The same idea has been supported by Lee \& Kotler (2005) stating that "corporate social responsibility is a continued commitment to improve community wellbeing through discretionary business practices" (Lee \& Kotler 2005) and contributions of corporate resources.

\subsubsection{Viewpoint of CSR according to Garriga \& Melé}

According to Garriga \& Melé (2004), the CSR theories are classified into four groups. These are 'instrumental theory, political theory, integrative theory and ethical theory' (Garriga \& Melé 2004). 


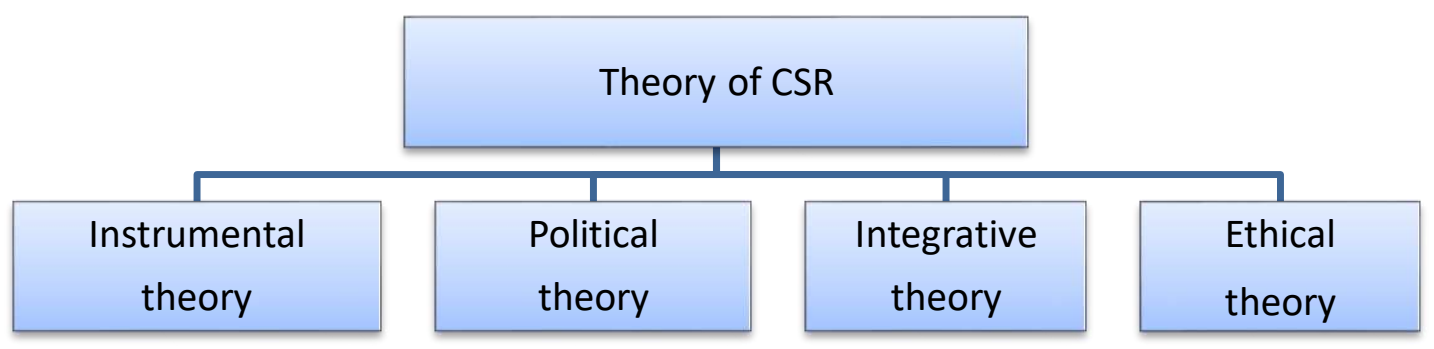

Figure 4: Viewpoint of corporate social responsibility (Source: Garriga \& Melé 2004)

The instrumentalists considered CSR to be instrumental in creating wealth for organizations (Garriga \& Melé 2004). The instrumental theories were focused towards achieving economic objectives of the corporations. The instrumentalists undertake CSR activities in order to generate profits.

The political theorists viewed CSR as a strategy adopted towards the responsible use of business influence in the political system. The political theorists assume that social responsibilities of organizations are due to the social power the company possesses.

An integrative theory emerged, focused on integrating social demands with business. Integrative theory claims that organizations are dependent upon society for their growth and continuity, instead of the other way around. Within this theory, the focus lies in meeting the interests of the stakeholders of the organization and responding to social processes and social issues.

The ethical theory is based on the principle of ethical values. According to the ethical viewpoint of CSR, the social responsibilities of companies are considered to be ethical obligations a company has towards human development, environment, labor laws and duties towards the stakeholders. An organization should focus on doing the right thing to achieve a good society (Garriga \& Melé 2004). 
Initially, the firms may adopt an instrumental view, and over a period of time, pass through stages of political and integrative views, and end up with an ethical view point on CSR. These viewpoints develop through various sub-stages. These substages could aid companies to enhance their philanthropic responsibilities. However, till today, in practice, not many firms accept their social responsibilities above any other consideration, as the ethical theory suggests (Donaldson \& Preston 1995). It may be noted that none of these separate theories fully grasp the concept of CSR; it would consider a new theory to be developed, attempting to combine existing contributions to overcome current limitations (Garriga \& Melé 2004).

\subsubsection{Viewpoint of CSR according to Secchi}

Secchi (2007) expanded the theoretical classification of CSR into a broad multidisciplinary viewpoint. He classified the CSR theories into 'utilitarian, managerial and relational theories' (Secchi 2007), as shown in figure 5 below.

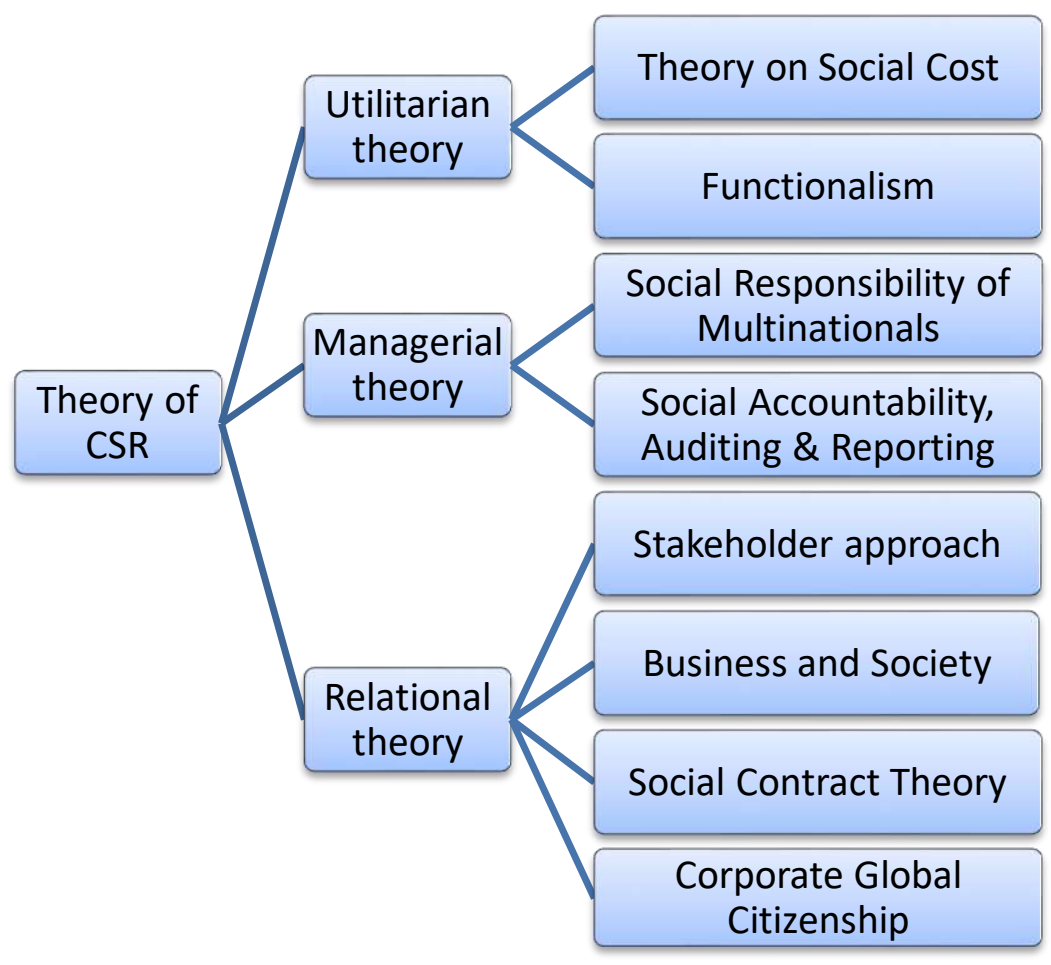

Figure 5: Viewpoint of corporate social responsibility (Source: Secchi 2007) 
The utilitarian theory examines CSR with a view of maximizing wealth; the managerial theory examines CSR through internal perspective of the firm, and the relational theory views CSR through firm's relationship with the environment (Secchi 2007), as explained below:

\section{A. Utilitarian theory}

Utilitarian theory views organization as a tool to generate wealth and maximize profits. The company is considered to be an economic entity with a defined function. Utilitarian theory is considered similar to the instrumental theory (Garriga \& Melé 2004) where the organization is treated as an investment entity for the purpose of creating wealth for the stakeholders and partners. The components of utilitarian theory include theory on social cost and functionalism.

(i) Theory on social cost

CSR involves an amount of social costs and this social cost has a direct relation with social performance.

(ii) Functionalism

The functionalists view firm as a part of the economic system whose goal derives from its definite function in the society (Secchi 2017). Friedman (1962, 1970) gives a narrow meaning to corporate social responsibility, treating it as a form of philanthropy. According to Friedman (1962, 133), "social responsibility and everything that goes beyond shareholders' interest is a 'fundamental misconception' of the character and nature of free economy." The shareholders believed the firm to be an investment, and therefore, investment has to be eligible and fruitful to the investors (Chamberlain 1973). 


\section{B. Managerial theory}

Managerial theory considers social responsibility within the organization. The managerialists believe in an organization centered view and consider organizational decision making as the basis of any action outside the firm. Managerial theory may be classified into social responsibility of multinational operations, theories on social accountability auditing and reporting; and corporate social performance.

(i) Social responsibility in international operations

Social responsibility among multinational corporations is gaining importance since the number of transnational companies is increasing, most of the firms based in the west expanded their reach to the developing and less developed countries. The international managers are practicing managers and when individual managers make a decision, the organization has responsibilities, going beyond the logic of profit (Donaldson 1996).

(ii) Social accounting, auditing and reporting (SAAR)

Social accounting, social auditing and social reporting are three separate managerial activities that occur in succession grouped together to form social accounting, auditing and reporting (SAAR). The emergence of social reporting was in the late 1960s, whereas social accounting and auditing began during the early 1970s (Bauer \& Fenn 1973). SAAR is sub-grouped into two categories - the first category to analyze the process and recommend suggestions and the second category to find the evidence of socially responsible behavior. The three general approaches followed are the sustainable model based on the United Nations Global Reporting Initiative 2000 , the SA8000 model for labor safety based on International Labor Office Declaration 2000, and the soft encouragement (European Commission 2001). 
(iii) Corporate social performance

Corporate social performance (CSP) is the managerial analysis of translating the social performance to economic value. CSP refers to "doing good." Corporate social performance enables an organization to determine the extent to which an organization is socially responsible. According to Wood (1991), Corporate social performance is defined as "the configuration of principles of social responsibility, social processes of social responsiveness along with programmes, policies and other observable outcomes of an organization in relation to the society" (Wood 1991). The outcome of corporate behavior refer to the principles and processes in an organization (Wood 1991).

Burke and Logsdon believe that "linking all the factors - corporate, social, economic and financial performance is a difficult task" (Burke \& Logsdon 1996). There is a need to elaborate on the relationship between these areas through a link. Strategy is the link that connects to social responsibility. "When policies, programmes, or processes of an organization are linked to CSR, it becomes strategic in nature"(Burke \& Logsdon 1996). Strategic CSR encourages business activities by 'supporting and helping the organization achieve its mission' (Burke \& Logsdon 1996).

\section{Relational theory}

Relational theory refers to an understanding of the organization, its environmental complexities and addresses issues based on their interactions. The relational theory places relationship as a foundation of analysis; and may be categorized into four types- stakeholder approach, business \& society, social contract theory, and global corporate citizenship (Secchi 2007). 
(i) Stakeholder approach

Stakeholder approach is a model for understanding relationships among various interest groups or individuals who has an interest in the business. According to Freeman, "a stakeholder is an organization or a group or an individual who can affect an achievement of an organization or is affected by the achievement of an organization's objectives" (Freeman \& Reed 1983).

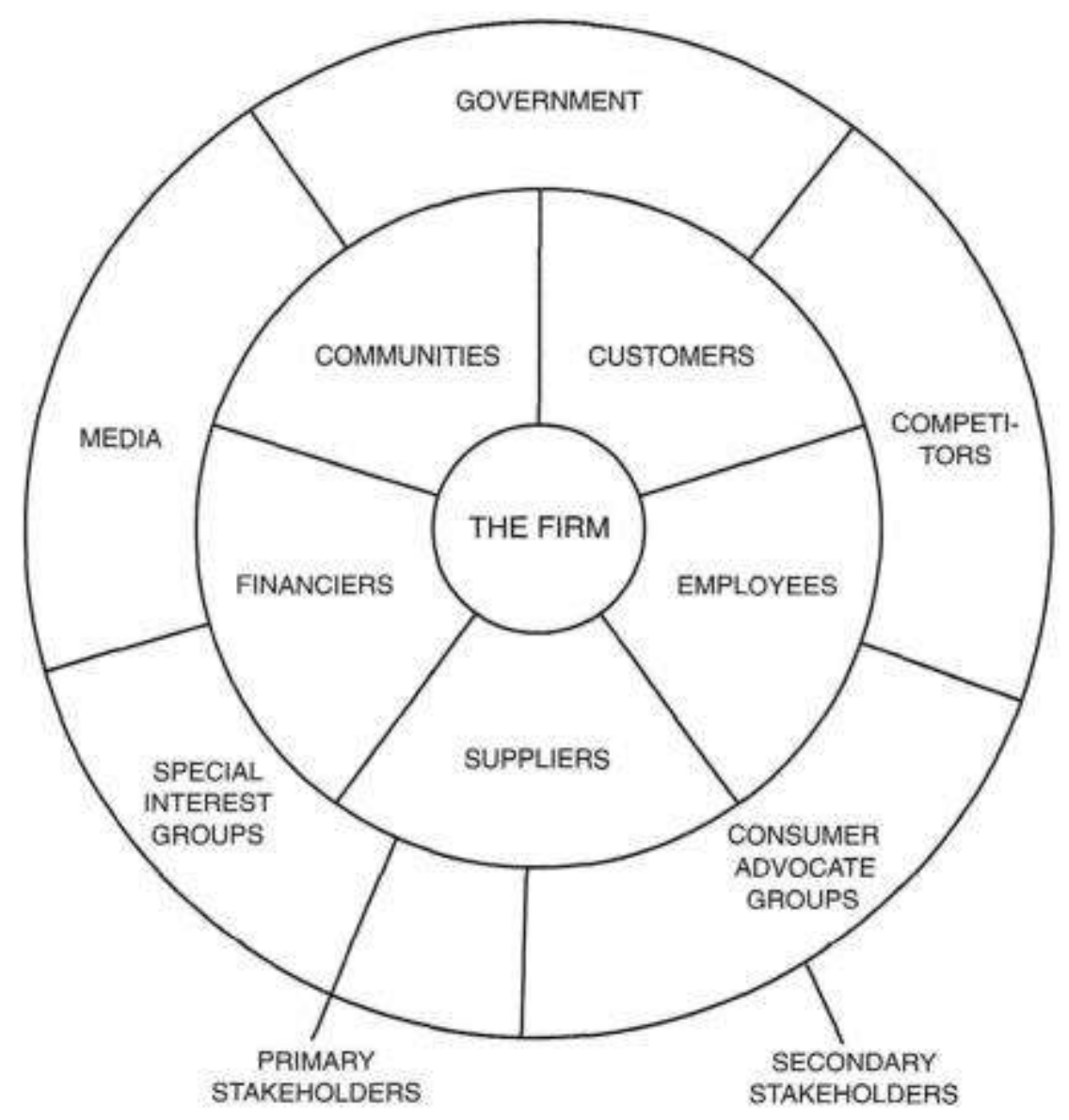

Figure 6: Stakeholder view of a firm (Source: Freeman et al. 2007)

Researchers Donaldson \& Preston proposed 'stakeholder theories that are descriptive, instrumental and normative' (Donaldson \& Preston 1995). The descriptive approach describes the behavior and characteristics of organizations such as the attitude of corporate board of directors, 
management approaches, the nature of organization, and the behavior of managers. The instrument approach links the management of stakeholders and corporate results in terms of measurements. The normative approach is concerned with 'analyzing organizational function and identifies ethical guidelines for managing the enterprise' (Donaldson \& Preston 1995).

According to Donaldson \& Preston, stakeholders are "persons or groups with legitimate interests in procedural and/or substantive aspects of a corporate activity"(Donaldson \& Preston 1995, 85). Stakeholder salience has assumed an important role. "The firm devises appropriate strategies in dealing with salient stakeholders"(Freeman 1984, Blair \& Whitehead 1989, Kimery \& Rinehart 1998, Polonsky 1996). Agle (1999) suggests that "organizations that address the interests of salient stakeholders will somehow perform better than the firms that do not address the needs of the groups"(Agle et al. 1999, Berman et al. 1999, Post et al. 2002, Wood \& Jones 1995). The way stakeholders are identified is the starting point for the conceptualization of stakeholder theory (Kaler 2003).

According to Milton Friedman, "there is only one social responsibility of business" (Friedman 1970), which he referred to as "using the resources of the company, and engaging in activities that are designed to increase the profits so long as it stays within the rules of the game" (Friedman 1970). This is to state that "a company engages in open and free competition without deception or fraud" (Friedman 1970). There are numerous stakeholders influencing the organization directly or indirectly. The managers of corporations shall remain ethical and continue to remain responsible towards all stakeholders involved while making decisions, even if these decisions affect profitability of the corporation. "Stakeholder theory is about creating value for stakeholders" (Freeman 1988). Stakeholders are identified through different ways. Mitchell and colleagues offered a popular and widely used set 
of non-normative criteria for identifying the stakeholders (Mitchell et al. 1997, 858). Mitchell, Agle \& Wood (1997) developed the concept of stakeholder salience based upon the work of Freeman, "Who or what really counts" (Freeman 1994). According to this theory, the attributes of stakeholders may be classified into three: power, legitimacy and urgency (Mitchell et al. 1997).

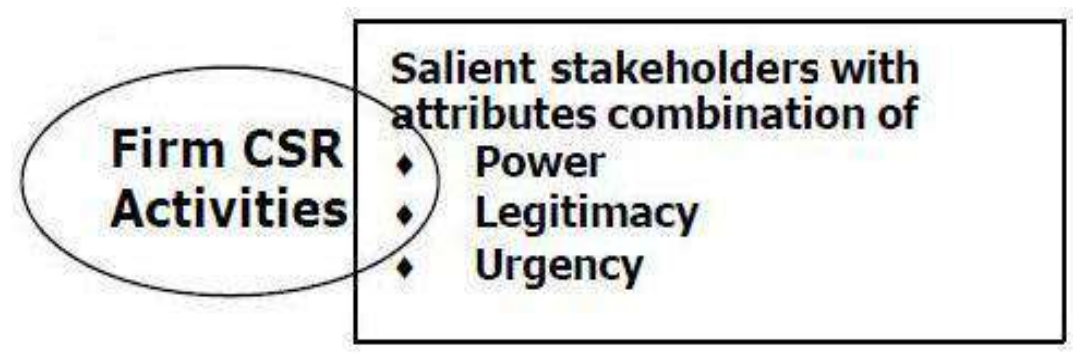

Figure 7: CSR activities with salient stakeholders (Source: Mitchell et al. 1997)

(a) Power: Power is "the ability of an individual to influence upon the other based on resources such as coercion, utility and financial capability, and on symbolic resources. These could be termed as cohesive power, utilitarian power and normative power and is used by stakeholders to impose their 'freedom and authority' in relationship to the organization" (Etzioni 1964). CSR can be performed with stakeholders holding differential power characteristics (Mitchell et al. 1997).

(b) Legitimacy: A stakeholder has legitimacy if he/she has legal right, moral right or is at risk of being harmed or benefitted by the actions of the company. "Legitimacy arises when a stakeholder is being harmed by the value chain activities of the firm" (Porter \& Kramer 2006). It is based on "a socially constructed system of norms, values, beliefs, and definitions" (Suchman 1995). A business organization has to undertake its value chain activities to produce goods or services it is meant to produce, but during this process if a 
stakeholder is harmed or hurt, then the stakeholder has a legitimate claim to be taken care of by the firm (Mitchell et al. 1997). Morally, the firm should attempt to internally minimize the negative externalities of its value chain (by means of certain CSR activities) and /or compensate through CSR activities to support the stakeholder. But a legitimate stakeholder may not have the power or urgency. As a result, they may not be able to influence the managers of the firm (Mitchell et al. 1997).

(c) Urgency: Urgency is stated as "a degree where the situation is critical and requires immediate action. Urgency has a component of criticality and sensitivity" (Jones 1993). While implementing a CSR programme, managers take decisions based on priority, need-based with a sense of urgency of the situation with the aim of minimizing or avoiding inconvenience or harm and maximizing benefits to the stakeholders. Mitchell and colleagues proposed that stakeholder salience has a relationship that combines stakeholder attributes of 'power, legitimacy, and urgency' (Mitchell et al. 1997, 873). "The salience of stakeholders could vary depending on the degree of attributes and the category of stakeholders"(Agle et al. 1999).

Strategic CSR is undertaken only when the CSR activity includes salient stakeholders. The CSR programme undertaken with "salient stakeholders are helpful in achieving strategic gains for the firm"(Burke \& Logsdon 1996). When a firm undertakes CSR with salient stakeholders (Mitchell et al., 1997), as represented in figure 7, then this CSR activity has to satisfy their needs and aspirations. In a situation where the CSR activity with a salient stakeholder goes wrong, then the salient stakeholder might cause damage to the firm. Therefore, any CSR activity undertaken with focus on salient stakeholder becomes strategic CSR activity for the firm. 
Four stakeholder groups emerge as powerful activists for CSR in emerging economies. These are development agencies (Jenkins 2005), trade union (Kaufman et al. 2004), international NGOs (Christian Aid 2004), and business associations (WBCSD 2000). These four groups of stakeholders assist the local NGOs and offer the necessary guidance in terms of implementing CSR activities.

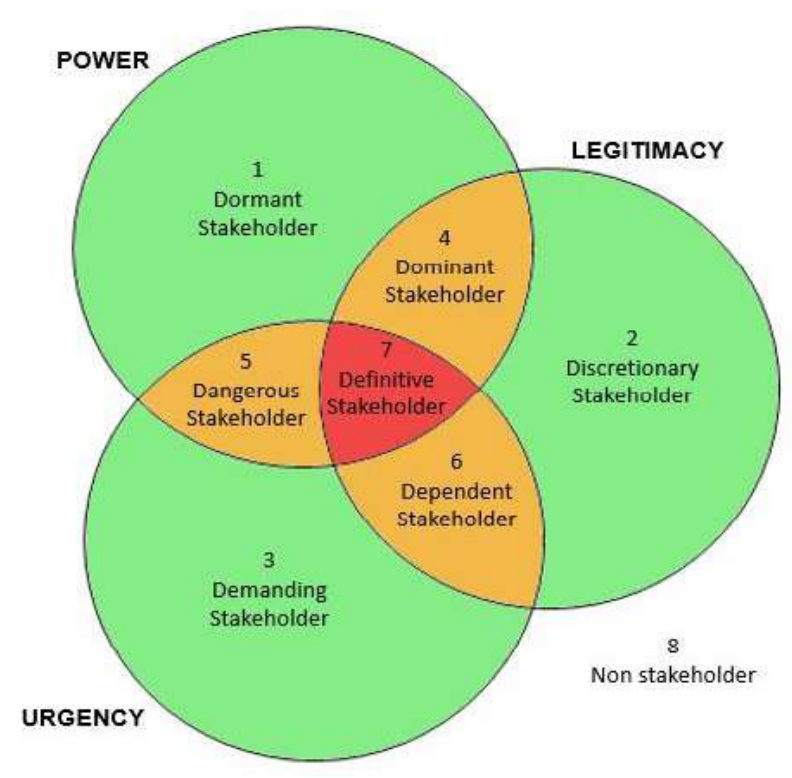

Figure 8: Classification of stakeholders (Source: Morphy 2015)

Stakeholder engagement: Stakeholder engagement is one of the important requirements in ISO and GRI procedures and it aligns the business practices with the needs and expectations of the society. According to Association of Project Management (2016), the ten important principles of stakeholder engagement are:

(a) "Communicating with a stakeholder to understand if the intended message on CSR is clear and simple 
(b) Consultation with the stakeholder asking the right questions to gain useful information or ideas on CSR processes \& policies

(c) Remembering to operate with an awareness of human feelings

(d) Careful planning \& deliberate approach so that the time and effort invested pays off

(e) Building relationships through mutual trust and seeking out networking opportunities

(f) Application of subtle skills such as empathy, interaction and listening to reflect an attitude of care and understanding

(g) Treating stakeholder as part of risk and opportunity with probabilities and impact

(h) Finding a compromise along diverging priorities of stakeholder and assessing their relative importance through a weighted hierarchy

(i) Examining the value of CSR project to the stakeholder and clarifying expectations and perceptions regarding success

(j) Taking responsibility of ongoing dialogue with the stakeholder"(IPMA 2016).

(ii) Business and society

Business and society refer to the analysis of the society and understanding the role played by organizations in the society and their interactions. Corporate social responsibility is the outcome of interactions of the organizations with the society. Business is defined as "development and 
processing of economic value in a society" (Davis \& Blomstrom 1966) resulting in interaction between company and other productive organizations. Thus, a person is obliged to take into account the effect of decision on the social system (Davis \& Blomstrom 1966), which builds up powerresponsibility equation of the manager or the owner of the company over society.

(iii) Social contract theory

Social contract theory is a new approach that brings together society, corporations, industries and economic system into a social contract. Donaldson \& Dunfee (1999) developed the social contract theory to establish moral constraints on relationship between the organization and the society. The social contract theory helps understand what is right and what is not right in a society. The 'moral norms' and 'moral free space' are the result of a social contract (Donaldson \& Dunfee 1999). Therefore, social responsibility is the outcome of corporation - stakeholder relationships, and is the basis on which the organization stands.

\section{(iv) Corporate global citizenship}

Corporate citizenship is the position occupied by the corporation in the community and the society. The corporate citizenship encourages 'interconnection and proactive engagement among members of the society, business organization and stakeholders leading to the transformation of the society and business' (Altman \& Vidaver-Cohen 2000). Corporate global citizenship and social responsibility are "voluntary in nature and goes beyond economic, social and legal duties" (Waddock \& Smith 2000). Through this process, the corporation aims to become a 'good citizen' and continue to maintain successful relationship with the society (Waddock \& Smith 2000, 48). 


\subsection{Importance of viewpoints on CSR}

The viewpoints of CSR discussed above enables a scholar or an industry practitioner to develop deeper understanding on the subject. The viewpoints of Garriga \& Melé (2004) and Secchi (2007) are based on recent developments on CSR. The dimensions of strategic CSR (Burke \& Logsdon 1996) links strategy to CSR and Carroll's pyramid of responsibility (1999) is the foundation of an organization's CSR activities and classifies organizations based on the level of CSR responsibilities.

Charity goes beyond philanthropy and stewardship is an essential trait of managers in implementing organizational strategies related to CSR. Based on industry experience in India, researcher believes that there is a requirement for corporations in developing countries to contribute significantly towards development of the society and the environment.

\subsection{Guidelines related to CSR}

Several CSR related codes, guidelines and initiatives were evolved and adopted by companies to prove that they were socially responsible in the countries they operate. The international conference on social responsibility (June 2004) hosted by the International Organization for Standardization (ISO) attracted stakeholders from 66 countries confirming consensus among the participants in favor of ISO's organized effort on CSR activities.

The guideline ISO26000:2010 is the process of social responsibility. ISO26000:2010 encourages organizations to go beyond legal compliance, assists organizations develop principles and undertake activities related to social responsibility and share best practices. The ISO guidelines are comprehensive and based on the principle of transparency; the value of public reporting on social responsibility and its performance towards internal and external stakeholders (ISO 2014). The ISO26000 standard identifies seven core principles for CSR. These principles are: 
'accountability, transparency, ethical behavior, respect for the interests of the stakeholders, respect for the rule of the law, respect for international norms of behavior and respect for human rights' (ISO 2014). ISO26000 (2010), points out the seven areas of social responsibility as: organizational governance, human rights, labor practices, the environment, fair operating practices, consumer issues, and community involvement \& development, as depicted in figure 9.

ISO14000 addresses environmental concerns, and provides a tool for companies and organizations looking to identify and control their environmental impacts. ISO14000 helps an organization constantly improve their environmental performance. ISO9001 assists an organization to develop its products and service that consistently ensures customer satisfaction and continuous improvement through Plan, Do, Check and Act (PDCA) approach (ISO 2010).

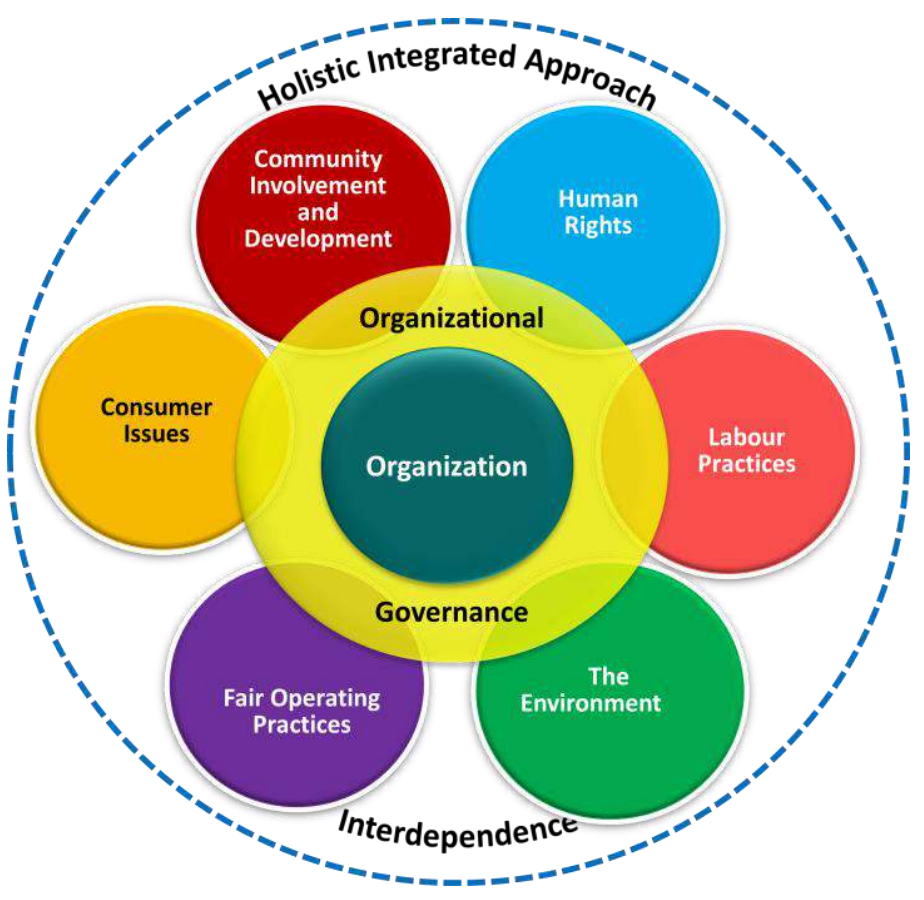

Figure 9: Seven areas of social responsibility (Source: ISO26000 Social Responsibility) CSR is mostly driven by standards adopted by multinational companies, persuading the subsidiaries in following procedures and systems implemented in conducting 
businesses worldwide. As reported by Chapple \& Moon (2005) in the study of multinational companies, it was observed that "multinational corporations are more likely to adopt CSR standards in their operations than those companies operating solely in their home country." It is important for the multinational companies that "the CSR practiced in a country of business operation meets the profile of the country of operation rather than the country of origin" (Chapple \& Moon 2005).

Other guidelines of CSR are AA1000 standards of AccountAbility. Guideline AA1000 assists an organization to achieve accountable, responsible and sustainable status. The AA1000 standard focus on issues related to governance, business models, organizational strategy, stakeholder engagement, green economy, carbon reduction and operational guidance of sustainability assurance (AccountAbility 2015). The "Sustainability Guidelines" developed by Global Reporting Initiatives (GRI) for reporting on social, economic and environmental dimensions of an organization, its products and services are an example. SA8000 developed by Social Accountability International for workplace condition based on international human rights norms. 'Business Principles for Countering Bribery' was jointly organized by 'Transparency International' and 'Social Accountability International'.

CSR has become a legitimate issue in the international diplomatic agenda. Several intergovernmental agreements on CSR, such as the International Labor Organization (ILO) convention have been in place for years. At the meeting of the World Economic Summit in 1999, UN secretary-general Kofi Annan announced the official launch of Global Compact on July 2000 in an attempt to get corporations around the world to voluntarily incorporate CSR into their operations. The objective of the Global Compact is to streamline and incorporate the ten principles of the United Nations in the areas of human rights, labor, environment and anticorruption to the business activities. This could initiate actions and achieve support for the 'Millennium Development Goals' for sustainable development (United Nations 2004). 
The UN Global Compact is one of the world's largest voluntary organizations for corporate sustainability initiative. UN Global Compact has an enrollment of over 12,000 signatories from business and key stakeholder groups from 145 countries. The Executive Director of the UN Global Compact stated that, "while corporate leaders recognize the importance of global sustainability issues, there are a lot more challenges to be met. Companies must put words into action. This is done through management efforts which include implementing policies, framework, measuring their effectiveness and reporting on their progress publicly."

Supply chains are a roadblock to progress. It has been reported that $54 \%$ of companies rank "extending sustainability through the supply chain" as the biggest barrier to advancement. Suppliers are increasingly expected to perform at the same level as the parent company demands, but in reality, it is difficult to ensure that the highest levels are practiced (Kristen, Coco 2013). Although business organizations in the United States are capitalistic, the USA was one of the first countries to acknowledge CSR to be a legitimate business concern as early as 1971 (Eilbirt \& Parket 1973). This suggests that CSR and firm performance are not mutually exclusive for businesses but may be complementary.

\subsection{CSR as a catalyst}

CSR fosters innovation. Unilever was able to bring innovation to a new hair conditioner that consumes less water. This effort was possible due to focus of the research and development team towards sustainability. Implementing CSR has helped companies reduce costs. According to the CSR report of General Mills in 2011, the company was able to save $\$ 600,000$ in terms of energy by installing energy monitoring meters on several pieces of equipment at its plant. CSR has been used by several organizations for brand differentiation. For example, in the cola wars, both Coke and Pepsi adopted innovative strategies such as zero net water usage, sustainable packaging, etc. (James, Epstein-Reeves 2012). 
Globalization has also played a significant role in catalyzing corporate social responsibility. It is not surprising that multinational corporations are the main proponents of CSR due to the high stakes involved (Commission of the European Communities 2001). Most leading MNCs headquartered in the west were pressured by the government regulators, the mass media, and the citizen groups (NGOs) to become socially responsible. The MNCs have presence in almost all world markets, with supply chains and manufacturing facilities located in several countries. With the advancement of modern information and communication technologies (social media), business operations have become more transparent. This heightened visibility ensures that the corporations are kept under scrutiny of the public if they behave unethically or irresponsibly.

The research highlights below a few cases of corporate wrong doings that happened during the last few years. The sweatshop labor scandal of mid-1990 by Nike, the footwear leader is an example (Nike answers Critics 2002). The pressure from the activists forced Nike to implement corporate social responsibility as a strategy in its business operation. Nike launched 'Transparency 101' programme to monitor facilities and ensure that its code of conduct was practiced across all locations. This programme was designed to make the public aware of everything that the company is doing. Nike made effort at all levels in its supply chain to ensure safe products and services to its customers. The success of Nike in CSR activities has been recognized by various groups; and the company has achieved recognition amongst 'America's Most Admired Companies' in the apparel industry. Moreover, Nike has been able to save over $\$ 100,000$ which is more than two million kilowatt hours of electricity and over two thousand therms of natural gas by improving energy efficiency, certifying all of its buildings in Oregon with 'Earth Advantage' (International Institute of Sustainable Development 2013).

The British Petroleum oil spill (April 2010) at the Gulf of Mexico, is considered one of the largest accidental oil spill in the petroleum industry. The volume of oil leaked is 
estimated at 4.9 million barrels impacting 68,000 square miles of ocean. British Petroleum faced about $\$ 42.4$ billion in civil and criminal charges since the disaster (BBC News 2013). The Mexico gulf residents and clean-up workers suffered serious health problems from the disaster. The complete clean-up took three years.

Violation of labor practices at Foxconn Company in China is another example. In a ten-page report entitled "New iPhone, Old Abuses," the social organization SACOM (Students and Scholars Against Corporate Misbehaviour) reported that workers at the Foxconn factory in Zhengzhou, China were forced to work overtime and were experiencing numerous work violations; such as excessive overtime between 80 to 100 hours per month (some of which were not paid). The workers were subjected to cramped and unpleasant living conditions. The report stated that 20 to 30 workers share a three-bedroom apartment stocked with bunk beds. The uses of high energy appliances were prohibited. On the contrary, the Foxconn representative stated that their employees are the greatest asset and that they are fully committed to ensuring a safe, satisfactory and healthy working environment. After the New York Times published the conditions of workers and the death of a worker who died due to an explosion at a factory that makes iPads, the Apple CEO Tim Cook defended stating that "the company cares about every worker in their worldwide supply chain" (Lowensohn 2012). Ellen Hertz, Professor of CSR pointed out that 'the Chinese electronics industry is lagging behind in implementing CSR. Although Foxconn had attracted public attention due to the Apple episode, it has since then promoted development of CSR in the Chinese electronics industry' (Syntao 2013).

Some of the well known corporate scandals are related to companies Enron, Compass Group, Arthur Anderson, Parmalat, Fannie Mae, WorldCom and Tyco International. The financial scandals that hit several large companies have tarnished their reputation and image, a valuable asset that made consumers sensitive. The abovementioned issues have resulted in catalyzing CSR across countries. 


\section{CHAPTER 3}

IMPORTANCE OF STRATEGIC CSR IN CREATING STAKEHOLDER VALUE

\subsection{Introduction}

The global scenario of business is highly competitive and has made it difficult for companies to survive. The competition, along with limitation of resources makes companies vulnerable. Hillman \& Keim (2001) considers CSR as a strategy to differentiate a company from its competition. Differentiation generates competitive advantage. Barney (1991) suggested that "corporate reputation could be considered as a source of sustained competitive advantage. The relationships between company and its stakeholders are socially complex and therefore imperfectly imitable" (Barney 1991). McWilliams \& Siegel (2001) created a structured framework for analyzing investments made by the companies in their CSR programmes through cost-benefit relationship. According to this framework, it was argued that the corporation will invest resources in CSR to a limit where the consumers and stakeholders appreciate the 'social attribute' in relation to the products and services delivered. This 'social attribute could be understood as the differentiating parameter for the company' (McWilliams \& Siegel 2001). The key stakeholders of business such as investors, employees, community appreciate the CSR efforts and intangible benefits offered to the society. The consumers support a company that engages in CSR activity and associates CSR with intangible values of reliability, quality and reputation.

\subsection{CSR \& organizational performance}

Research has found varying degrees of relationships between CSR and organizational performance. These are "positive, negative and neutral relationships among them and the inconsistencies could be due to improperly defining the issues, incorrect research design or sampling methodologies" (McWilliams et al. 2006). A firm entails the risk of being labeled as irresponsible by not engaging in and not displaying social responsibility and accountability. Companies might be willing to start investing in 
corporate social responsibility based on expectation of the indirect benefits they will receive. Studies relating to CSR activities and financial performance of corporations have shown that "there exists a distinction between the effectiveness of CSR activities that are altruistic and strategic" (Hillman \& Keim 2001). According to scholars Hillman \& Keim (2001), "strategic CSR has a positive influence on the financial performance and a negative relationship with altruistic CSR." A competitive advantage is created through stakeholder management and investment plans which develop resources and capabilities for the organization to compete. These could not be easily copied by the competing organizations. The companies are thus able to "expand, develop capacity and exchange value with all stakeholders through long term interactions that are more relational rather than transactional" (Hillman \& Keim 2001).

Social issue participation does not generate a competitive advantage because it is largely a transactional investment which can easily be duplicated by competing firms (Hillman \& Keim 2001). Research suggests that many altruistic types of CSR practices, such as triple bottom line reporting or local social issues participation, are relatively easily duplicated by numerous organizations. The relationship management that supports organization seems more valuable than that of the symbolic management in meeting stakeholder expectations. The literature on CSR offers little explanation on how those organizational practices are related to social and environmental concerns in delivering competitive advantage.

\subsection{CSR, value chain and context of competitiveness}

Porter \& Kramer (2006) proposed a framework for performing certain CSR functions on a company's value chain, suggesting that CSR function supported either the primary activity or the supporting activity in an organization. The CSR programmes help secure inputs, control cost, maintain flow of goods and services through inbound/outbound. This would contribute to the value chain activities in an 
organization (Porter \& Kramer 2006). Similarly, "CSR activities, if incorporated in support function (procurement, manpower development, technology development, firm infrastructure, etc.) of the firm's value chain, would lead to organization's competitiveness" (Porter \& Kramer 2006). This has been pictorially represented in figure 10 below.

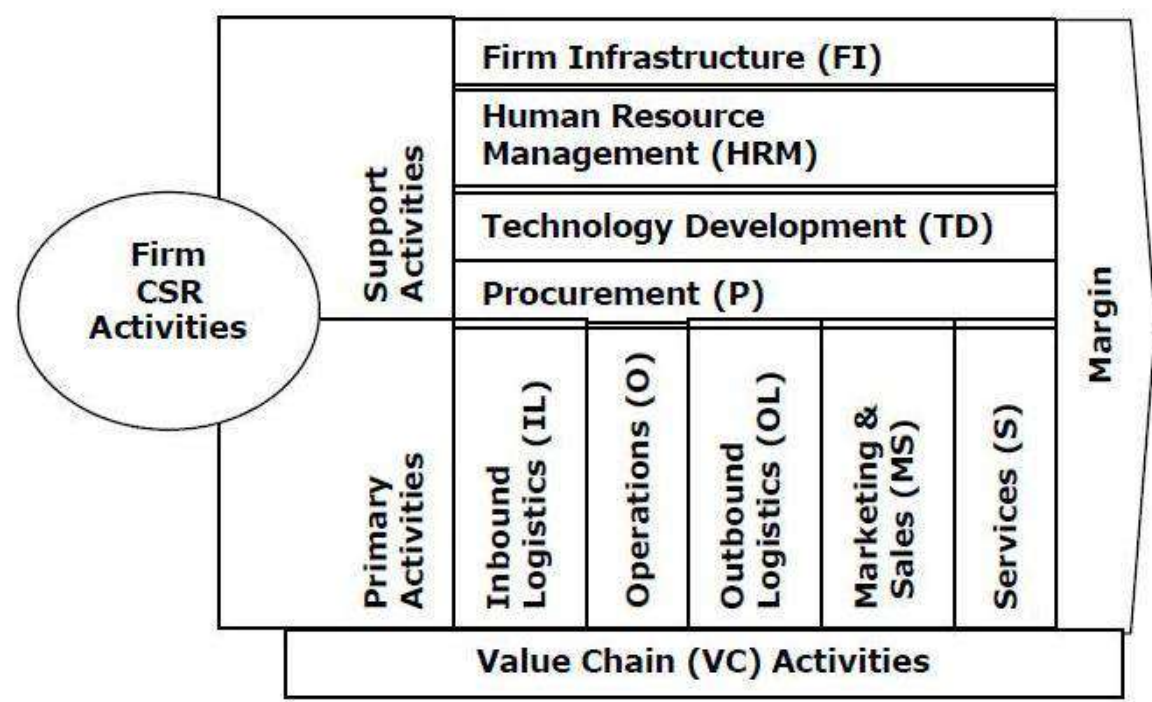

Figure 10: CSR activities contributing to value chain of the firm (Source: Porter \& Kramer 2006)

Porter \& Kramer suggested that CSR becomes strategic when it enhances the competitiveness of an organization (figure 11 below). Undertaking CSR activities could improve factors of infrastructure, skilled labor, demand for goods and services, production, environment friendly products and thus maintain higher standards of quality, safety and reliability. These factors are necessary for competing in an industry. The demand for products and services in the local market could be enhanced through an effective CSR strategy. The initiatives of CSR could help in formulating systems and frameworks, rules and regulations, protection of Intellectual Property Rights, safeguard investments, create strategy and structure in favour of the organization. CSR also plays a role in creating infrastructure by building and supporting related industries. Therefore, organizations benefit from implementing 
CSR initiatives. Thus, CSR function has strategic significance when focused towards the competitive context of a firm.

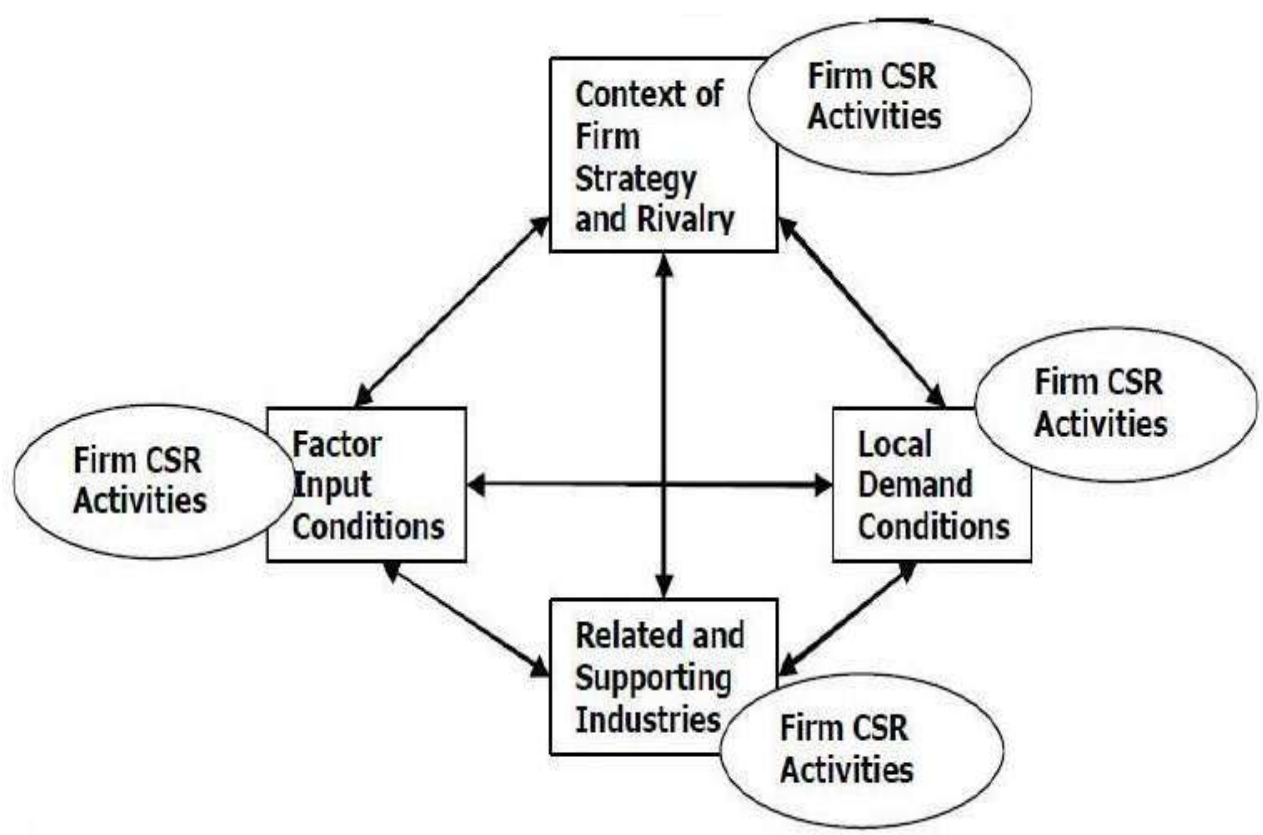

Figure 11: CSR activities improving the context of competitiveness of the firm (Source: Porter \& Kramer 2006)

\subsection{Benefits of CSR to the corporation}

The CSR can be used as a differentiation strategy to satisfy relevant stakeholders, and to achieve product differentiation (McWilliams \& Siegel 2001). However, the ability to differentiate from competitors in the industry is one of the several advantages of engaging in corporate social responsibility. A well-designed CSR programme can lead to direct and indirect benefits for a firm. The direct benefits include appreciation in market value of the firm (Lo \& Shue 2007), and improved financial performance due to increase in sales effort (Garriga \& Melé 2004) brought about by the marketing activity or due to an image created by the firm. This leads to an increase in sales revenue, thus generating increased cash flow into the company. 'All these efforts could be perceived by the company as a predecessor of behavioural loyalty' (Chaudhuri \& Holbrook 2001). 
Van den Brink, Odekerken-Schröder \& Pauwels (2006) identified that long-term marketing campaigns based on CSR can increase brand loyalty. CSR campaigns have the ability to build brand equity through "building brand awareness, usage and image, establish brand credibility, evoke emotional appeal, create a community of brand loyalists, and support brand engagement" (Hoeffler \& Keller 2002). Associating a brand to a specific good-cause or a specific project involves emotional connection. This emotional connection leads to goodwill and enhanced corporate image. In addition to enhancing corporate image, the CSR communication has the ability to create synergy by countering the negative publicity (Varadarajan \& Menon 1988).

However, companies are not always and unconditionally rewarded for their CSR performance. Under specific circumstances, consumers' intention to purchase a certain product might even decrease due to CSR initiatives (Sen \& Bhattacharya 2001). It is essential that consumers value the type of CSR activity implemented by the company. Also, consumers should be able to perceive a coherent fit between the organization's core business and the social issues it is involved in. Furthermore, consumers are generally not willing to compensate for product, price and quality to buy socially responsible products (Bhattacharya \& Sen 2004).

In addition, Aupperle, Carroll \& Hatfield (1985) state that companies making investments in CSR will incur higher investment than that of the organizations that do not, and they find no difference in profitability between such firms. Yet, the indirect benefits a firm receives when consumers value the firm's CSR activities, which are able to compensate for the extra costs. Increased investments can also occur because the firms invest increased resources in creating awareness of their CSR efforts among the public. Generating awareness of CSR effort is a prerequisite for a favorable response (Bhattacharya \& Sen 2004, 14). The companies need to "communicate cautiously since consumers prefer brands with selfless motivation (altruism) to engage in philanthropic behavior over brands supporting a social cause with the intention to generate sales" (Barone, Miyazaki \& Taylor 2000). 
An example is the success of Ben \& Jerry's ice cream worldwide. Ben \& Jerry's used CSR as a tool in its communication. The corporate communication of Ben \& Jerry's was based on environment and animal welfare. In 1989, the company communicated their opposition to the use of genetically engineered recombinant hormone given to cows for enhancing milk production. In 2003, the company transformed all packaging materials to eco-friendly packaging. The company actively highlighted social issues in its communication. In its corporate communication, under 'current initiatives', Ben \& Jerry's (2008) highlighted 'a fair and global economy, social justice and environment' focused on fair trade practices and story about cocoa farmers who were benefited through Ben \& Jerry's fair trade practices. Under the title 'social justice,' Ben \& Jerry's (2008) have built a theme around various social topics such as 'marriage, equality, peace building and equal rights'(Ben \& Jerry 2008). Under the title 'climate justice,' Ben \& Jerry's educated students on climate change, and its efforts in reducing carbon footprint (Ben \& Jerry 2008). By communicating these values continuously, Ben \& Jerry's has been able to achieve an impressive image and brand value without investing much on the marketing front (Ben \& Jerry 2008). Nevertheless, "the true motives of a company's CSR performance do not matter to consumers since they are only influenced by perceived motives" (Morales 2005).

\subsection{Responses to CSR programmes}

Engagement in CSR programmes stems from the managers' feelings towards philanthropic responsibility, stakeholders' pressure to behave socially responsibly, the belief that it will enhance financial performance (Maignan \& Ralston 2002) or a combinations of the above. On the whole, it is expected that people will appreciate company engagements in the CSR programmes. This appreciation probably elicits feelings of gratitude among an entire spectrum of affected stakeholders. Gratitude exists as an affective trait, and can be defined as "a general tendency to recognize and respond with grateful emotion to the roles of other people's benevolence in the 
positive experiences and outcomes one obtains" (McCullough, Emmons \& Tsang 2002, 112).

In particular, gratitude is a moral affect that is similar to other well-recognized moral emotions such as guilt or remorse and compassion or empathy (McCullough et al. 2001). Gratitude in itself is an emotion that stems from the ancient concept called 'norm of reciprocity' (Gouldner 1960). A reciprocity imbalance occurs due to perceived unequal exchanges between individuals, and feelings of indebtedness arise due to intrinsic belief that mutual exchange of goods or services should balance out in the long-run. These negative feelings of being in debt with someone generate a positive feeling of gratitude and the response to reciprocate favours equally (Gouldner 1960).

Even though reciprocity essentially refers to an exchange of equivalents, the exchanged services could vary as long as it has an equal value. Since corporate philanthropy is not obliged by law or ethics as required by the society, CSR can be seen as an extra step made by companies as a good deed towards stakeholders. Yet, the theory of reciprocity implies that "for a favour to evoke feelings of gratitude it should be directly aimed at a specific person" (Gouldner 1960), whereas CSR programs are mostly directed to several customers and several stakeholders at the same time.

According to Morales (2005), those favours that have no direct benefit and do not directly evoke feelings of being in debt evokes a positive feeling of gratitude among consumers. Research in the field of psychology has found that "people are more likely to feel gratitude towards a favour that is valued by the receiver, expensive for the benefactor, offered with benevolent intentions, and given gratuitously or without specific reason" (McCullough et al. 2001, McCullough et al. 2002, Tesser et al. 1968). These specific factors seem to hold true for the concept of corporate social responsibility; thus, implying that CSR programmes have the ability to evoke feelings 
of gratitude within customers. Therefore, it may be stated that CSR refers to the responsibility undertaken by organizations to influence customers, employees, shareholders, communities and environment in its spheres of activities. This commitment of business may be defined beyond the statutory obligation of fulfilling the legal requirements and voluntarily attempting an effort to improve quality of life of the employees, their family members, the local community and the society.

The following section examines environmental and social issues with literatures related to relationship management in providing further insights into the firm's value which may play in contributing to the strategic advantage of the firm.

\subsection{CSR and corporate identity}

There are clear and identifiable benefits associated with CSR when it comes to adding value to human capital, corporate identity and products. The scale and nature of the benefits of CSR for a company may vary depending on the nature of enterprise and the CSR it undertakes. Although the business advantages gained from CSR are often difficult to quantify in an exact way, there is a large body of literature available which highlights key business advantages of CSR and urges businesses to adopt sociallyconcerned measures beyond financial gains.

\subsubsection{Brand and reputation advantage}

In competitive markets, companies strive to create a unique selling proposition that separates them from their competitors in the minds of customers (differentiation). As a result, the value created by a company depends largely on trust and confidence the customers have on the business. This trust and confidence is built through continuous commitment of the business in meeting and customers' expectations. Brand equity is built through a sustained effort over a period of time bringing about a positive change in customers' attitude towards a product or service. This perception 
of customers about a company and its products turns into value. For most companies, a brand is the core and backbone of business.

CSR plays an important role in building brand equity and company reputation based on distinctive ethical values. Several brands, for e.g.: The Body Shop, Whole Foods Market, and American Apparel have built their enterprises on ethical values such as human dignity, ecologically sustainable operations and socially responsible practices. Through their reputation in developing and delivering sustainable products and services, they have attracted socially and environmentally conscious customers. This approach, also known as "green marketing," has been employed by companies as a marketing strategy. For e.g. Home Depot developed a line of furniture produced entirely from sustainably harvested wood.

Organizations that perform well with regard to CSR practices build their reputation; whereas those that perform poorly damage brand and company value when malpractices are exposed. The cases of Foxconn, Nike and Shell mentioned earlier emphasize and illustrate this. The loss of a positive image and reputation impacting the brands is simply too high to ignore. This is particularly important for organizations with high-value consumer brands, which become a focus of the media, the activist and the consumer group. In such situations, undertaking CSR activities may reduce the impacts caused by negative publicity.

Companies in the supply chain could gain a positive image and reputation through implementing CSR. As large companies consolidate supply chains, smaller companies need to differentiate themselves to gain and retain business while competing with larger companies in a small segment. Small and medium-sized enterprises (SMEs) may benefit by improving their image and reputation as some large companies are looking to identify smaller enterprises with market standing, reputation for good quality and economically priced products produced in a way that is considered as 
socially responsible (ESCAP 2005). Brand equity and environmental responsibility are beneficial to the corporation, either large or SMEs, in a global and competitive world.

\subsubsection{Human resources value}

The ability of firms to succeed in the future is often linked to how well a firm captures value through people, process and technology. Competent human resources thus have become a key to sustained corporate success. There is growing evidence that a company's CSR practices play an increasingly important role in attracting and retaining talents, particularly within a competitive market of technical specialists. A systematic study conducted among junior- and senior-level students in the US found that firms with more numbers of CSR practices were perceived to be better attractive employers than the firms with fewer CSR practices, and that the prospective applicants' job pursuit has a positive association with CSR. Results of an employee survey by 'Good Search' indicate that " $44 \%$ of employees want to work for a company that is environmentally responsible, that has stated CSR policies (38\%), those that produce socially responsible products (37\%), and that conducts ethical sourcing and supply chain (35\%)"(CSR Wire 2008).

A survey conducted by British Telecom (BT) stated that "more than one-third of respondents indicated that working for a caring and responsible employer was more important than the salary they earned" (Vorster 2007). Almost half of the respondents suggested that 'CSR policies should be compulsory in the organization.' A quarter of the respondents believed that the influence of business is next only to the government (Vorster 2007). Good internal CSR practices (such as fair employment practices, diversity initiatives, openness, freedom, flexibility, bonus schemes, and the like) could increase the morale, reduce absenteeism, enhance commitment of workers to the organization and increase productivity; all of these subsequently contribute to retaining talented employees and performance of the organization. Good CSR practices improve communication and team building within 
the organization when the employees are involved in various activities such as fundraising or community volunteering. All these efforts bring employees together as one team and bring about positive feeling towards the company.

\subsubsection{Cost advantage}

The cost advantage of CSR appears to be related to two aspects: business operations and human resources management. There are several examples to prove that cost reductions can be achieved through good CSR practices. Many of these cost reductions are related to the environmental management of business operations. The companies that reduce pollution also attempt their efforts in reducing the usage of hazardous materials in their operations. They undertake sustainable measures such as recycling of waste, reuse of materials and operate with energy efficiency. The efficient use of resources such as electricity, fuel and water contributes to significant cost savings. DuPont, for example, has saved over $\$ 2$ billion from reductions in energy use from 1990 to 2005 . McDonald's changed the materials used to wrap its food and reduced its solid waste by $30 \%$.

The cost advantage is achieved through improved efficiencies as identified by a systematic approach to management that includes quality systems and continuous improvement. For instance, in assessing the environmental and energy aspects of an operation, a company can create opportunities through transforming waste streams into revenue streams (for e.g.: wood chips into particle board), as well as identify areas for system-wide reductions in energy use, and costs. Herman Miller Inc., an office furniture company in the US, achieved this distinction by transforming waste materials into wealth. It sells fabric scraps to the auto industry for use as car linings; leather trim to luggage makers; vinyl to the supplier to be re-extruded into new edging; and burnable solids are used in a specialized boiler that generates all the heating and cooling for the company's main complex in Michigan. Herman Miller Inc., ultimately makes money from "waste" that it previously had to pay to dispose of. 
From the human resource management aspect, the benefits of CSR can be largely considerable when recruitment costs and costs of training new staff are considered. The contribution of CSR towards staff retention was explained in the previous section. Some SMEs use good CSR practices to develop a sense of family within the organization, as opposed to a workforce divided into management and workers. The SME sector may be well suited to cooperative forms of ownership that tends to increase retention of employees, boosts loyalty, productivity and performance.

\subsubsection{Brand value}

A brand is the value offering of a company that serves a purpose/ benefit to the customer or a user. Brand management plays an important role in generating value for a company and has a strategic advantage through differentiation and positioning. A brand is created in the minds of users through segmentation, targeting and positioning strategies. The customers, users and various key stakeholder groups represent an influence on the brand through competitive advantage (Chandrasekar 2006). CSR plays an important role in creating competitive advantage and is used as a valuable tool by marketers to create a position in the minds of customers. The consumer pays much attention to the social responsibility image created by a brand. According to Harish Bijoor, "the future of marketing is full of CSR" (Bijoor 2008). CSR is a strategy used by marketers in building trust in the minds of consumers and users.

Brand value has significance and focus on developing markets since consumers look for brands that deliver sustainable value and offer products that are effective, safe, convenient, low cost and long lasting. Although technology could be a differentiating parameter of a quality brand, organizations have began to realize the intangible value appreciated by customers in developing markets. These intangible value could be a positive attitude towards a brand or towards the employees which has a direct bearing on their morale. Organizations that have gained reputation of and position as 
a good corporate citizen shall be able to leverage the intangible assets to its advantage through strategic positioning (Edenkamp 2002).

Organizations have realized that in order to gain strategic advantage and compete in the marketplace, there is a need "to shift focus from profits to responsible business etiquettes" (Raynard \& Forstater 2002). The corporate social responsibility is an important strategy which brand managers use in order to effectively communicate product offerings and value delivered to the users. There are companies that undertake numerous CSR practices, but fail to take advantage of it for boosting brand equity and sales.

In today's world, mainstream consumers look out for ethical, sustainable or responsible brands. The fact is that all business functions in the society must pay attention to the latent needs of the customers; understand social issues and environmental impacts, and direct their effort towards reducing adverse effects or neutralizing the consequences. The concepts of values are rapidly merging in the minds of consumers. People want to be associated with organizations that share a common value (Scott, Beaudoin 2009). CSR is a tool that helps companies to leverage and sustain competitive advantage by using their "social contribution to link the brand with the purpose at subconscious level of advertising" (Fry et al. 1986). CSR is one of the important promotional tools for popularizing a product or service. CSR creates brand awareness, brand recall and makes a brand stay longer in the minds of consumers through creating an emotional attachment to the brand. The awareness, image, usage and equity of the brand increases if CSR is used as a part of brand strategy.

An example is Amul, a brand built through farmers' cooperative body- Gujarat Cooperative Milk Marketing Federation (GCMMF), which began in 1946 as a dairy cooperative movement. Amul was created with the aim of helping rural farmers in the state of Gujarat in India. Today, Amul has a membership of 3.37 million farmers 
from 18,536 village societies. During the year 2014-2015, Amul cooperative collected 5.42 billion liters of milk from the farmers. Today, when food security is of prime importance for India, Amul played a significant role in delivering value added milk and dairy products and helped India achieve recognition of becoming the largest milk producer in the world. "India's milk production has more than trebled from 21 million tonnes in 1968 to 80 million tonnes in 2001 (Gupta 2000) and to 132.4 million tonnes in 2012-2013; and this has become an important secondary source of income to 70 million rural households" (Whitehead 2014).

The story of 'Lijjat papad' reflects the determination of women cooperative in integrating structure and systems to support a strategy in delivering value to the society. 'Lijjat' is a common household name for crispy and spicy bread in India. With a humble beginning in 1959, Shri Mahila Griha Udyog Lijjat Pappad, the cooperative organization currently empowers more than 40,000 women members following the philosophy of self-reliance and trusteeship. The organization is managed by a committee of 21 members who decides on the functioning of the organization. The profits are shared among all members of the cooperative based on their contribution.

The driving force behind the success of Lijjat organization is 'sarvodaya philosophy' wherein every sister member of the organization contributed and shared this common vision. Sarvodaya was Gandhi's important socio-political movement referring to 'welfare for all' (Gandhi Foundation 2016). “The 'Sarvodaya Samaj' was founded in March 1948 with the objective of building a social order based on truth and nonviolence. Such a social order is free from all caste differences and exploitation, and would offer development for the individual and the society. The Sarvodaya Samaj followed a decentralized pattern, free from domination, immorality and injustice" (Dharmadhikari 2014). 
Any quality conscious woman willing to come forward, adopt the vision and values, and contribute to the team can become a co-owner of the Lijjat cooperative. Equality is respected in Lijjat pappad. "Lijjat pappad has a policy of electing the highest office bearer from the lowest ranks" (Chaki 2013). Today, Lijjat pappad is a brand that has crossed \$200 million in sales value, with presence across several countries. "The Lijjat's current workforce comes from the poorest sections of the society for whom a life of dignity would otherwise seem difficult" (Chaki 2013).

Investments in corporate social responsibility generate value to the stakeholders and organizations in several ways. "Marketing of corporate social responsibility is one such area of creating value" (Van de Ven 2008). "Marketing tools may be used to promote a good cause in an effective way" (Kotler \& Lee 2005). In a competitive market scenario, corporate social responsibility is positioned as an initiative that has strategic importance to several companies. CSR has a positive influence in creating value for the organization. Investments in CSR help managers reap financial benefits involving important stakeholders and customers who are socially centered (Luo \& Bhattacharya 2006). CSR is reported to influence consumer responses directly or indirectly through several ways, such as identifying and appreciating the company, offering donations to not-for-profit organizations and in forming a favourable opinion towards the company's products (Brown 2001).

Brand building is a gradual process with sustained efforts and investments in resources and intellectual capital. The business model is an important criterion to be considered for creation of a sustainable and responsible corporation. The business plan must communicate an idea and purpose for developing a responsible brand or company. It must not reflect exploitation of stakeholders but must address concerns of the society. In a crowded marketplace, companies strive for a unique selling proposition that distinguish them from the competition, CSR plays a role in building customer loyalty based on distinct ethical values. 
The CSR activities should be able to bring about positive developments to the people who are poor, and enhance their livelihood by creating new markets at the base of the socioeconomic pyramid. A focused effort will be able to meet the needs of untapped market of 4 billion people, but also convert them to brand loyal customers of products and services (Prahalad \& Hammond 2002, London \& Hart 2004, Rangan et al. 2007). This could result in companies being seen as creators of new markets for their products and services, and at the same time meeting the social requirements through various CSR programmes. Therefore, CSR is a source of competitive advantage for the companies (Baskin 2006) in the emerging markets.

\subsection{Catalyzing CSR in emerging markets}

CSR in developing countries has either been generalized (e.g. Frynas 2006) or focused on a national scale. According to Pedersen \& Huniche (2006), "the following three journals - 'Journal of Corporate Citizenship' (Issue 24, 2006), 'International Affairs' (81(3), 2005) and 'Development' (47(3), 2004) point out CSR activities across emerging markets. Most of the articles on CSR were published from countries: China, India, Malaysia, Pakistan, South Africa and Thailand" (Pederson \& Huniche 2006). Although CSR has been a topic of discussion among researchers and academicians, less research has been done with reference to CSR in developing countries.

In a study conducted by Baskin (2006) evaluating CSR activities undertaken by 127 major organizations from emerging markets with that of 1700 companies that are leaders from the Organization for Economic Cooperation \& Development (OECD) countries, it was found that "across 21 developing countries in Asia, Africa, Central and Eastern Europe, and Latin America demonstrated a pattern of CSR" (Baskin 2006) reflecting similarities in CSR among developing countries.

Baskin (2006) found that the companies from emerging markets have a presence in the Dow Jones Sustainability Index. These companies also have "an increasing acceptance of Global Reporting Initiatives' Guidelines and ISO14001 standards" 
(Baskin 2006). It has also been observed that more than two-thirds of the companies from emerging markets in the study sample either had a sustainability report or a section on their website or in their annual report highlighting CSR initiatives undertaken by them. On analyzing environmental reporting of all the companies under study, it was observed that all the companies from emerging markets and OECD followed a similar pattern.

Moreso, the companies sampled from emerging markets published a detailed report on corporate social investment activities compared to that of the OECD counterparts (Baskin 2006). Baskin (2006) also found that the companies from emerging markets lagged behind the companies from OECD countries with respect to reporting on two areas. These are reporting on 'business ethics' and 'equal opportunities.' South Africa is an exception when it comes to reporting on 'equal opportunities'. On analysis of women members on board of the company, it was found that Norway and South Africa reported a larger number of women on board compared to a fewer women on board in Japan and Latin America. With regard to training, occupational health and safety, South Africa and Western Europe had a higher focus compared to those of North America and Asia.

Although it is interesting to note the similarities in CSR activities among developing and developed countries, the sample of African countries selected by Baskin (2006) were only two out of fifty-three countries. Thus, it may be concluded from the Baskin's (2006) study that there may not be much differences in the CSR activities undertaken by the companies under study among the OECD countries and emerging markets.

\subsubsection{CSR in Asia}

The awareness level and adoption of CSR practices are generally low in Asia compared to that of the developed countries in the west. It appears that globalization of markets has contributed to the increasing spread of CSR in Asia 
(Chambers et al. 2003). It was reported that after the establishment of a non-profit Centre for CSR in Singapore in 2003, there was an "increased attention to CSR from the mass media, the academia, the government agencies, and the corporations, although the overall awareness level was still considered low" (Hung \& Ramasamy 2004).

As mentioned in the previous section, the Asian countries predominantly highlighted in the literature on CSR are China, India, Indonesia, Malaysia, Pakistan, and Thailand (Visser 2008). Other Asian countries mentioned in the literature are Bangladesh, the Pacific Forum Islands, Sri Lanka \& Vietnam (Visser 2008). Birch \& Moon (2004) observed that CSR performance among the Asian countries varies with regard to CSR issues. The most common issues of CSR were in the fields of employee welfare, education, livelihood; and those CSR activities related to meeting basic needs were undertaken through foundations, volunteering, and partnership through nongovernmental organizations.

Chapple \& Moon (2005) analyzed the variance in CSR among Asian countries and reported that "nearly $75 \%$ of all large companies in India were found to have CSR policies and practices compared to that of only $25 \%$ in Indonesia." Chapple \& Moon (2005) also recorded that the CSR initiatives undertaken by companies in Thailand, Malaysian and Philippines were in the range $42 \%, 32 \%$ and $30 \%$ respectively. The research concluded that CSR initiatives evolved in Asia in three waves. The most established form of CSR initiatives being community involvement, followed in succession by socially responsible production process and employee relationship (Chapple \& Moon 2005).

Welford (2005) compared CSR initiatives of 15 countries across Europe, North America, and Asia and reported that the CSR from countries Hong Kong, Malaysia, Mexico, and Thailand recorded a low response. Upon comparing 20 areas of CSR among developing countries with that of the developed countries, it has been 
reported that developing countries consistently underperformed in CSR activities (Welford 2005). In terms of CSR performance, Thailand scores high in terms of external issues such as child labor and business ethics. Hong Kong performed better in terms of internal parameters such as equal opportunities and non-discrimination. Malaysia is considered the weakest amongst all (Welford 2005).

\subsubsection{CSR in Africa}

CSR is imperative across African continent due to widespread poverty and colonization. Only a little research has been done on CSR in Africa, except for South Africa and Nigeria. Environmental degradation by large mining companies is another major issue in Africa. The early years of 2000s saw large scale mining activities in Africa. The rise of extractive industry and increase in income from natural resources have not contributed to a significant poverty reduction. For example, despite doubling the economic output during 2000-2010, the poverty remained unchanged in Zambia, a major producer of copper (Chuhan-Pole et al. 2017).

South Africa has an important role among African nations in implementing CSR (Visser 2005), while opportunities for further research exists in other parts of Africa such as the Ivory Coast, Kenya, Nigeria, Tanzania, Mali and Zambia. The journal 'Corporate Citizenship in Africa' (Visser et al. 2006) highlights articles on CSR in Africa (Issue 18, Summer 2005). Visser has also reported that "the academic institutions and researchers undertaking research specifically on corporate citizenship in Africa remain a few" (Visser et al. 2005, 19). On a detailed review of the literature on CSR in Africa during the period 1995 and 2005, Visser (2005) found that only 12 out of 53 countries in Africa have published research in core CSR journals. Visser (2005) also observed that " $57 \%$ of all articles published were focused on South Africa and $16 \%$ on Nigeria" (Visser 2006a). The CSR reported in Nigeria were focused towards Shell and its policies adopted in Nigeria, and its impacts on the Ogoni people (Ite 2004). 
Visser (2005) stated that " $42 \%$ of all articles on CSR in Africa during the past decade were focused on business ethics." This could be due to the historical reasons of colonialism, apartheid, corruption and fraud prevalent in Africa. The literature review of early 1990s reflected issues related to apartheid, whereas it was only after 1994 that the focus shifted towards business ethics of South African managers (Visser 2005). "Areas such as health, social responsibility and stakeholder engagement will gain importance as CSR increasingly addresses these issues in an African context. It is likely that economic and philanthropic areas of CSR (rather than legal and ethical responsibilities) will continue to dominate CSR practice in Africa" (Visser 2007).

\subsubsection{CSR in Latin America}

Chile and Peru account for half of world's largest copper mines. According to Economic Commission for Latin America \& Caribbean (CEPAL), 13 countries from Latin America and the Caribbean are among the 15 major suppliers of mining resources in the world. The region possesses the second largest oil reserve, and is the third largest producer of bio-ethanol in the world (Martin \& Hanni 2013). The development of extractive industry has an important role in the economic activity and has a major impact on the social, cultural and environmental areas. Therefore, Economic Commission for Latin America demands that the mining sector faces the challenges of protecting the environment, ethnic minorities and sustainable development (López- Morales et al. 2017).

Among the Latin American countries, Argentina (Newell \& Muro 2006), Brazil (Vivarta \& Canela 2006), Mexico (Weyzig2006), Nicaragua (Prieto-Carron 2006a) and Venezuela (Peindado-Vara 2006) were the countries reported in the literature 'Journal of Corporate Citizenship' (Issue 21, Spring 2006). According to De Oliveira (2006), the CSR in Latin America has been influenced by socioeconomic and political conditions. Schmidheiny suggests that "CSR could bring about a major change in terms of improving social welfare, reducing harm to the environmental degradation, 
preventing corruption, and improving the economy" (Schmidheiny 2006). There are more than 1,000 Latin American companies which are members of EMPRESA, the CSR network of Latin America. Of these, 300 companies were members of the World Business Council for Sustainable Development (WBCSD). It is reported that 1,400 companies in Latin America were ISO14001 certified and 118 were members of the UN Global Compact.

Moreover, the Brazilian Academy of Management (ENANPAD) published a large number of articles (De Oliveira 2006) on CSR during the year 2005. The CSR study conducted by Araya (2006) in Latin America highlights that $34 \%$ of the 250 companies surveyed published the sustainability report in a separate section of the annual report of the company. Araya also observed that " $43 \%$ of the Brazilian companies reported their sustainability activities in the annual reports while $22 \%$ of them reported their sustainability activities in sustainability reports, as compared with that of the Mexican companies (33\% and 25\%) and Chilean companies ( $22 \%$ and $16 \%$ ) respectively" (Araya 2006).

Newell (2005) observed that 'the economic crisis in Argentina during 2001-02 marked a significant turning point in implementing CSR, prompting debate on the role of business in poverty alleviation.' Vives (2006) studied 1,300 small and medium enterprises (SMEs) of Chilean and Argentina origin. It was reported that "the companies in Chile and Argentina have undertaken an increased number of CSR activities compared to that of those SMEs in Brazil and EI Salvador. The CSR focus of the SMEs was on internal activities directed at employee welfare compared to that of the environment or the philanthropy" (Vives 2006). 


\subsection{Factors contributing to CSR in emerging markets}

\subsubsection{Influence of culture}

In the modern context, CSR is believed to have originated in the western countries. However, this is not correct. CSR has a deep-rooted tradition in the ancient cultures where business ethics and conducting business honestly and sincerely were part of ancient culture. The 'Arthashastra' (also called the science of politics) is an ancient Indian treatise on policy, strategy, economic policy and state craft. Authored by Kautilya, also known as 'Chanakya or Vishnugupta,' between 2nd and 3rd Century BC. The Arthashastra includes governance, statecraft, diplomacy, civil and criminal court system, ethics, market, economics and trade, methods of screening ministers, culture and social welfare. The Arthashastra contains actions to be taken by rulers during the times of calamity, epidemic, famine, acts of nature and war; and it includes protection of forest and wildlife. It states that the king should initiate public projects such as construction of dams, irrigation canals, fortification and exempt tax from those affected (Olivelle 2013).

Frynas (2006) pointed out the moral principles of business advocated by Kautilya in the ancient India. Visser \& Macintosh (1998) pointed out the condemnation of business practices in the ancient civilization. This includes prohibiting exorbitant interest rates charged in regions where hinduism, buddhism, islam and christianity were practiced. Nelson (2004) suggested that 'the beliefs in buddhism were the reasons for Asian way of life aligned to the CSR'. Chapple \& Moon (2005) stated that "CSR in Asia vary considerably among nations, and that the variation is a result of the national business system followed in the Asian countries."

\subsubsection{Socioeconomic transformation}

CSR in emerging markets has a direct relationship with the society and the social transformation process, and contributes to ethics and values. Researchers have 
argued the link between social transformation and political reform. De Oliveira (2006) points out the changes brought about in Latin America due to political and socioeconomic transformation during the 1980s. These changes were brought about through a process of transformation that include liberalization and privatization.

Similarly, it has been reported in South Africa that political changes have brought about freedom, democracy, equality and justice. These efforts contributed to improved corporate governance through corporate social responsibility (Roussouw et al. 2002), a collective business action for social upliftment (Fourie \& Eloff 2005), empowerment of the black and economic freedom (Fig 2005), and business ethics (Malan 2005). Visser (2005) lists several examples of factors influencing economic, social, environmental, and labor laws that have contributed to a direct influence on CSR in South Africa during the period 1994 and 2004. Moreover, several countries in the Eastern Europe initiated focus on implementing CSR to align with the good CSR practices undertaken by the European Union (Baskin 2006).

\subsubsection{Socioeconomic environment}

CSR has a direct influence on the socioeconomic environment in a developing economy. Companies in emerging countries support the government in undertaking developmental activities such as infrastructure development, education, healthcare, poverty alleviation, etc. Amaeshi et al. (2006) argue that CSR in Nigeria is directed towards supporting the social issues and economic challenges of the country. The role of CSR is much different in a developing country or least developed nation compared to that of the CSR undertaken in a developed country. The challenges of CSR in a developed country are green marketing, protecting the environment, consumer protection, fair trade, climate change issues and socially responsible investments. In a similar way, Schmidheiny (2006) quoted cases from Latin America where the role of CSR should be directed towards supporting local issues which are social and economic in nature, such as eradicating poverty, solving unemployment, 
environmental protection, preventing crime and bringing about economic development (De Oliveira 2006).

\subsubsection{Corporate governance}

Governance is an issue in most developing and least developed nations. A weak institution with poor governance transfers responsibility to the private institutions. Blowfield \& Frynas (2005) observe it as 'an alternative to government' which is 'frequently advocated as a means of filling gaps in governance that have arisen with the acceleration of liberal economic globalization' (p. 508). Moon (2002a) argues that the governments share responsibility with the corporate through a public-private partnership.

Matten \& Crane (2005) suggest that corporations enter the arena of governance wherein the government has not been able to fulfill the rights of the citizens such as improving living conditions, working conditions in sweatshops, ensuring employees a living wage, and financing the schooling of child laborers. Hamann et al. (2005) argues that "a proactive role is required in moving local governance towards accountability and inclusiveness and that CSR is an inadequate response to these governance gaps." When the communities become dependent on corporations for meeting their social needs through CSR activities, there could be issues with regard to dependence of the company on its shareholders. An example is given below, about how a company got involved in social administration of a village in India.

Kizhakkambalam village, located in Ernakulam district of Kerala has a population of 23,186 people. Kizhakkambalam was traditionally a farming village transformed into an industrial village. The manufacturing sector in the village includes Kitex Garments, Anna Aluminium, Sevana Packaging Machines, Polyguards Equipment and Tools, Waves Electronics, and a few others (Digparty 2016). Kitex Limited employs about 12,500 people. It is reported that the village administration denied a permanent pollution control license to the company for causing pollution beyond the permissible 
levels (Kumar, Sunil 2015). The company set up a charitable trust 'Twenty20' in May 2013. It issued four types of cards - blue, green, yellow and red cards based on income to the members of the village. Of the 8000 families, 6700 have registered with the Twenty20 trust. It was observed that 4627 families (approximately 71\%) were categorized as red (low income) and yellow (below poverty line).

The company spent an amount of rupees 340 million (\$5.616 million) on social developmental activities since the inception of Twenty20. The initiatives were undertaken in the areas of providing clean drinking water to the villagers, electrification, sanitation, regulating the public distribution system, health care, farming, subsidized provision in the night market, loans for marriage, etc. (Ittyipe 2015). The company contested the October 2015 village panchayat election in 19 wards, of which it won mandate in 17 wards. Subsequently, the company took initiatives in transforming Kizhakkambalam into a model village. The company supported the industry in complying with regulations; and provided wireless internet access to everyone in the village. The information presented above is an example of how corporate responsibility and corporate accountability along with stakeholder involvement could lead to social development (Damodar 2016).

The requirements put forward by the multinational companies on the small and medium supply chain partners in developing countries could be a driving force for implementing CSR. Allegations of child labour, improper working conditions, inadequate safety of workers, human rights abuses, mostly in the garments and textile industries paved way for CSR initiatives in these supply chain (Hussain-Khaliq 2004, Kaufman et al. 2004, Nielsen 2005). Ethical trading initiatives (Blowfield 2003, 2004) resulted in 'fair trade auditing and labeling certification for agricultural products sourced from developing countries' (Dolan \& Opondo 2005, Schrage \& Ewing 2005). 


\subsection{Categories of CSR activities}

The commercial organizations undertake diverse CSR activities in order to fulfill their social obligations. Welford (2003) classified these social activities under four categories -internal, external, accountability and citizenship dimensions (Welford 2003; Williamson et.al 2006). The first category is the internal dimension, and it includes anti-discrimination policies, equal pay, health, and safety. For example, in the contemporary times where only 12 of the Fortune 500 companies are led by women, many companies attempt to raise the number of females in their topmanagement functions to increase corporate diversity in terms of gender (CNN Money 2008).

The second category is the external dimension which entails acts such as environmental protection, prohibiting corruption, fair-trade practices, and respect for human rights (Williamson et al. 2006). For example: 'Fair-trade', wherein suppliers who are paid fair prices are promoted among companies around the world by the non-profit organization 'Fair-trade Labelling Organizations International' which certifies Fair-trade products with a well-recognized label (FLO International 2008). At the moment, Starbucks is the largest buyer of fair-trade certified coffee around the world (Fair Trade Certified 2008).

Thirdly, Welford (2003) mentions about the accountability dimension which includes a commitment to communicate results, and incorporate a wide range of stakeholders. Several multinational companies are committed to socially responsible business practices and are eager to share this with their customers. For example, the German company SAP launched its first sustainability report in 2008, stating the key measures of its corporate, environmental and social, and governance performance (CSR Wire 2008).

Finally, support for social, educational and sustainable development programmes fall under the citizenship dimension. Recently, the globally recognized Coca-Cola 
Company partnered with WWF and promised to provide major funding to improve water efficiency and reduce carbon emission within its system-wide operations (CSR Europe 2008). The latter dimension most strongly resembles the philanthropic view of Carroll (1991), and as such, this report focuses on CSR activities described by the citizenship dimension. This recent classification considerably adds to the development of a widely accepted definition of corporate social responsibility. The diverse CSR activities undertaken by different companies may be categorized in these dimensions, making it easier to recognize the stage a corporation is in, and to define its level of corporate social responsibility.

\subsection{Issues related to CSR}

The issues that represent an organization's CSR focus vary by size (small, medium and large), depending on the industry sector in which the organization competes, and to a certain extent by the geographic region. The CSR issues may broadly be classified to include issues related to products and services, environmental management, standardization, philanthropy, legal compliance, code of conduct, supply chain, human resources and health, all of which are classified under three categoriesenvironmental issues, social issues and economic issues.

These three categories have four influencing factors - marketplace (related to economic issues), society and work place (related to social issues) and environment (related to environmental issues). In order to develop an effective CSR, the issues are linked to corresponding stakeholders who have an influence in the system.

\subsection{Gaps in literature}

Based on literature review, following research gaps have been identified:

(i) In spite of the presence of literature on the role of corporate social responsibility in the areas of the environment and the society, there 
exists a gap on how corporate social responsibility can create value for the corporations and the society.

(ii) Some studies pay importance to the linkage among corporate social responsibility, the corporation and company size. However, it is necessary to pay importance to the seven elements: strategy, structure, systems, style, skill, staff and shared vision (McKinsey's 7S framework).

(iii) Although Carroll's pyramid is a good model for explaining the responsibilities of an organization, there seems to be a lack of holistic framework that exhibits the process of value creation for the organizations and the society.

(iv) There is no evidence depicting relationship between corporate social responsibility and organizational performance that include financial and nonfinancial parameters.

\subsection{Hypotheses \& its rationale}

The following hypotheses are examined in this research:

H1: The five dimensions of strategic CSR (centrality, specificity, proactivity, voluntarism and visibility) create value for the firms.

H2: The four categories of corporate responsibilities (economic, legal, ethical and philanthropy) create value for the firms.

H3: The three components of CSR (charity, stewardship and environmental friendliness) create value for the firms. 
Rationale

A. The five dimensions of strategic CSR (centrality, specificity, proactivity, voluntarism and visibility) create value for the firms:

Burke \& Logsdon (1996) argue that CSR helps create strategic benefits for the firms. For example, the organizations involved in CSR activities could generate an outcome in a positive long-term financial impact (Murray \&Vogel 1997). Kotler \& Lee (2005) highlights on how CSR engagements could help companies achieve an increase in market share and sales turnover, strengthen brand image, improve corporate image, brand value, attract, motivate and retain talent; thus reduce operating costs, influence investors and financial analysts.

According to Barney (2001), economic value is created (for a company) when the company is able to achieve an increased revenue for the products and/or services than the cost incurred for the production and selling them. In the CSR realm, creating value may be defined as "identifiable and measurable economic benefits that a company anticipates" (Burke \& Logsdon 1996, 497). Value generation is achieved when an organization combines resources, applying newer methods such that the potential and productivity of those resources are achieved (Moran \& Ghoshal 1999; Schumpeter 1934). Value creation is regarded as tangible or intangible aspects of an organization, not exclusively about innovation (Schrage 2007, Jacobides et al. 2006, and Edwards et al. 2004).

Studies have revealed that CSR innovation creates economic value for firms under a specific set of circumstances (Burke \& Logsdon 1996, Kanter 1999) whereas all the tangible and intangible aspects may not create economic value for an organization (Margolis \& Walsh 2001). It has been observed by stakeholders that social initiatives may increase cost to the company and stockholders may consider this as a decline in shareholder value even though CSR programmes may create value for different stakeholder groups. In order to demonstrate awareness among 
shareholders that CSR create economic value, the model of five dimensions of strategic CSR developed by Burke \& Logsdon (1996) was incorporated in the study.

B. Influence of pyramid of CSR (Carroll 1991, 1999) on value creation:

According to Carroll (1970, 1991, 2016), the four categories of responsibilities (economic, legal, ethical, philanthropy) are the foundation that helps to delineate and frame the nature of responsibilities of companies towards the society.

Economic responsibility

The economic contribution of business organizations has been appreciated by the governments and the society in developing countries. The developing countries possess resources in terms of manpower and materials to attract foreign direct investments. The economic and social contributions of business organizations in eradicating hunger and poverty, enhancing quality of life, education and well-being of citizens have a positive bearing on the companies. Fox (2004) argues that "this should be viewed as a developmental efforts of CSR that focuses on creating an environment for responsible business in developing countries, and efforts to bring about economic freedom, equality and sustainable development." Crane \& Matten perceive this effort as "an approach adopted by European companies compared to the profitability focus adopted by the American multinational companies" (Crane \& Matten 2007a).

The aims of CSR in developing countries are capacity development, economic development, income generation, investment in resources, creating jobs, livelihood, supporting infrastructure, technology, building human capital and institutional networks (Nelson 2003). The companies operating in developing countries have increasingly reported on their economic responsibility by constructing 'economic value added' statements. Economic responsibility has a contribution and dependence factor. There could be a factor of risk involved if the government, community and 
other stakeholders overly depend on the multinational enterprises. These could be compromised on social, ethical or environmental fronts which could lead to various consequences when the companies, due to its dominant position could use its sphere of influence (Visser 2008).

Legal responsibility

Most often, in the developing countries, legal responsibility occupies a lower priority compared to that of the economic responsibility. Several developing nations have inadequate legislation to protect their resources. Moreover, the developing nations are often deficient in resource utilization. These factors could result in inefficient administration (Visser 2008). Most developing countries do not have standard policies on human rights and other framework relevant to CSR in their legislation (Mwaura 2004). In recent times, some of the developing countries have made progress in improving their social and environmental legislations (Visser 2005b). There are also limitations on enforcing CSR in most developing countries due to irresponsible business behavior such as tax avoidance by the companies (Christensen \& Murphy 2004).

\section{Ethical responsibility}

Visser (2008), in his book 'Corporate Social Responsibility in developing countries', refers to Crane \& Matten suggesting that Europe pays higher importance to the ethical responsibility compared to that of the USA. With regard to developing countries, although there is an improvement in governance, ethical responsibility has not been given much importance in the CSR programmes (Visser 2008). Visser (2008) suggests that the '1992 King Report' focused on the importance given to business accountability beyond the interest of shareholders (IOD 1992). The 'Revised King Report of 2002' contained a separate section highlighting ethics, health, safety, social transformation and environmental management under a chapter 'Integrated Sustainable Reporting' (IOD 2002). One of the common ethical issues reported among 
all the developing countries is that of corruption among officials holding positions in the government (Visser 2008).

Philanthropic responsibility

The philanthropy in the western countries tends more often to be "compulsory through legal framework than discretionary effort of successful companies or rich capitalists" (Crane \& Matten 2007a). The developing countries have an indigenous tradition of philanthropy and the same is expected of the business. The domestic companies in developing countries generally perceive philanthropy to be the best way in which they could contribute to the development of the society. According to Visser (2005), several developing countries were under the influence of foreign assistance during the second part of the last century. Therefore, there is a culture of philanthropy built into the business of developing countries. Philanthropy is an early stage of maturity in the CSR and most developing countries consider CSR to be same as that of philanthropy. The unmet needs and demands of the society in developing countries make philanthropy an expected norm and it is considered to be the right thing undertaken by the business (Visser 2005). "Carroll's CSR pyramid is, probably the most known model of CSR" (Visser 2006).

The pyramid of corporate social responsibility (Carroll 1979, 1991) identifies a wide range of commitments that the companies have toward the society. It serves as a framework, which primarily focuses on the economic value generation, but also asserts legal, ethical and philanthropic behavior of firms. Carroll terms it as 'the four faces of corporate citizenship' (Carroll 1998). The pyramid of CSR is a comprehensive, though general framework. Carroll's CSR pyramid possesses key research constructs to develop an instrument for undertaking empirical studies, which are still nascent. Surveys using questionnaires as an instrument was undertaken to establish the applicability and validity of CSR pyramid. The purpose is to understand the 
perceptions of respondents in the corporate India to the four broad responsibilities stated above.

C. Influence of Lawrence, Weber \& Post's (2005) charity and stewardship; and environmental friendliness on value creation:

Another area of current research is to analyze the principles of charity and stewardship developed by Lawrence, Weber \& Post (2005); and environmental friendliness among companies operating in India.

Principle of charity

Charity is the art of raising money and offering help for the needy with the purpose of providing benefits to the community by way of support in education, religion, relief from poverty and community betterment. The effort of charity is directed towards the society or community and not just towards an individual, group or organization. Charity has been an important component of strategic CSR among the corporations. Social enterprises and charitable organizations need not be the same. Social enterprises tend to have worth goals such as social wellbeing or environmental sustainability (Atawhai 2017) as shown in figure 12 below. The current research identifies the role of business organizations in India in generating value in supporting a social cause by means of contributing to charity.

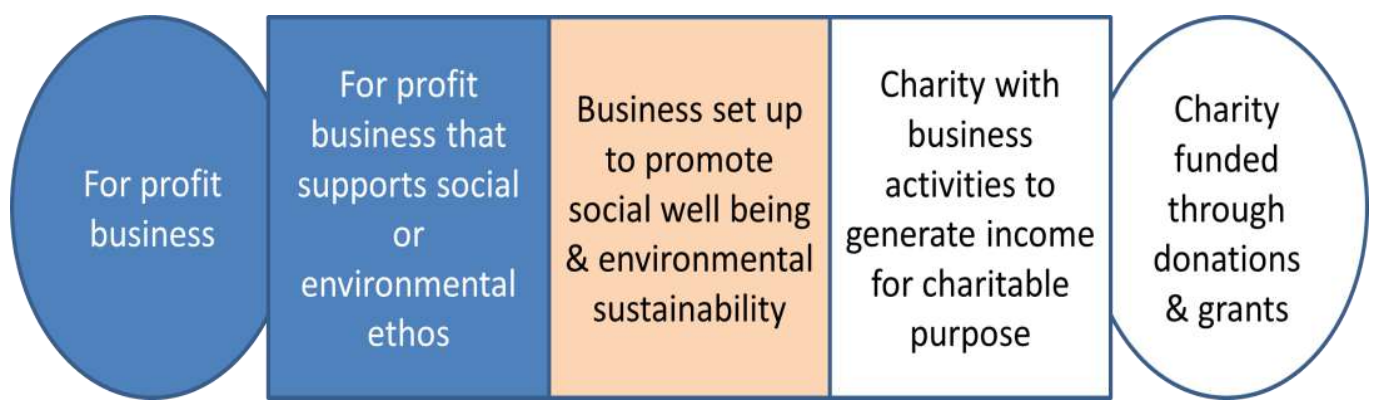

Figure 12: Social enterprise combining social good and commercial goals (Source: Atawhai 2017) 
Principle of stewardship

There are four theories of corporate governance - agency theory, stewardship theory, stakeholder theory and sociology theory. Stewardship is the practice of actively safeguarding and enhancing an organization's ability to create over time. Stewardship involves taking pride in duties and responsibilities of an organization (Hwee 2016). Stewardship plays an important role in the long term success of an organization. Everyone in an organization should adopt a stewardship role in an organization. According to Hwee (2016), "good stewardship practices are - learning, following and upholding the policies of the corporation. Supporting and enhancing mission of the corporation and safeguarding the assets (human, physical, financial and reputational) of the corporation."

The stewardship principle expects companies to be keepers or stewards in the interest of the society. The companies must make sure that the society benefits from the decisions and actions of the corporation. The stewardship principle highlights interdependence between the corporation and the society (Tan et al. 2006). Although the organizations act with a motive of self-interest, their efforts would be focused towards balancing the interests of various stakeholders, supporting them for purposes such as environmental activity or social welfare. Corporations play an important role by providing job opportunities, income, equality, health and equal wealth distribution; thereby play an important role in sustainable development, considering the future of all people. Corporations such as Unilever, Novo Nordisk design their production, human resources practices and management processes to optimize positive and mitigate negative impacts on the communities, and stakeholders (Lawler 2017). Low employee involvement is a challenge to stewardship. Several employees, particularly the younger generation are less inclined towards ownership of the job. A reason could be shift towards contract or part time job, leading to frequent job changes. An organization has to make additional efforts 
in order to develop a culture of stewardship (Hwee 2016). The research identifies the components of stewardship that create value for the corporation.

Environmental friendliness

Hart (1995) proposed the concept of natural resource-based-view, also called RBV framework. He explained the reason for companies to engage in environmental responsibility. Through the RBV framework, companies are able to undertake environmental responsibility programmes and create a sustainable competitive advantage (Hart 1995). The important strategies identified in the environmental programme include 'pollution prevention, product stewardship, and sustainable development' (Hart 1995). Sustainable development, in the RBV framework, is defined as "mitigating the impact of negative link between economic development in developed countries and resultant environmental degradation in the developing world" (Hart 1995). Although the concept of RBV framework aligns with the concept of CSR, the scope of CSR has grown beyond the issues of the environment, focused towards corporate sustainability (Branco \& Rodrigues 2006). Therefore, the CSR activities should generate resources for the firm and create competitive advantage through a corporate strategy. 


\section{CHAPTER 4}

\section{RESEARCH METHODOLOGY}

\subsection{Research approach}

There are two general research approaches, which are qualitative and quantitative research methods. This study employs both qualitative and quantitative approaches. Qualitative research methods are less structured and more intense than questionnaire based interviews. There is longer and more flexible relationship with the respondents and the data obtained provides an insight and perspectives about the problem (Saunders et al. 2009). Quantitative research method is a formal and structured method. It generalizes and studies research problem in a broader perspective. The sample identified is large with fewer variables so that the problem can be evaluated statistically.

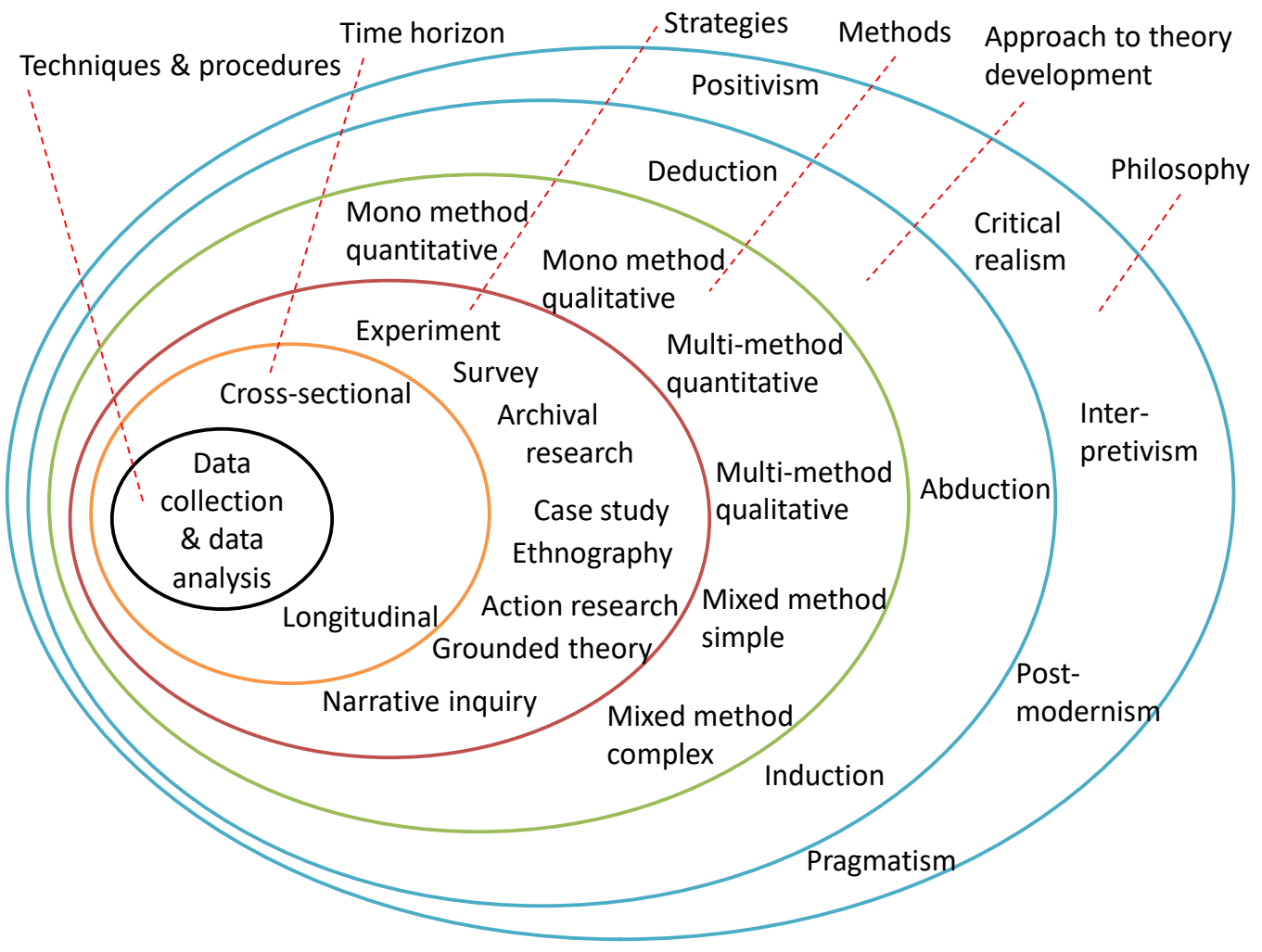

Figure 13: The research onion diagram (Source: Saunders 2015) 


\subsection{Research design}

The research design employed in this study is 'mixed sequential exploratory model design' for theory development and theory testing (Tashakkori \& Teddlie 2003). In this mixed sequential exploratory model design, the first exploratory (qualitative) phase enables the development of theory, whereas the second (quantitative) phase tests and generalizes the theory developed in the first phase. Mixed methods approach is one in which the researcher tends to base knowledge claims on pragmatic ground (consequence oriented, problem centred, and pluralistic). The mixed sequential exploratory model design employs strategies of inquiry that involve collecting data either simultaneously or sequentially to best understand the research problem. Data collection involves 'gathering both numeric information (e.g.: questionnaire) as well as text information (or interviews using open ended questions) so that the final database represents both quantitative and qualitative information' (Creswell 2003).

\subsection{Research strategy}

Keeping the research problem and hypotheses in mind, the researcher determines following strategy: CSR activities are driven by the needs of organizations in creating market value or business value for firms. The companies identified are multinational companies (MNCs), Indian private sector companies (Indian private) and Indian public sector enterprises (PSEs) undertaking CS (corporate sustainability) and/or CSR activities. These companies may also be undertaking activities towards Sustainable Development Goals or both CSR and SDGs as a part of corporate strategy in India.

(a) Qualitative study

The qualitative study focuses on corporate sustainability and CSR initiatives undertaken by multinational companies, private sector and public sector enterprises in the Indian corporate sector. 
(b) Quantitative study

The quantitative study evaluates dimensions of strategic CSR developed by Burke \& Logsdon (1996), Carroll's pyramid of CSR (1991), principle of charity and stewardship developed by Lawrence, Weber and Post (2005); and environmental responsibility in creating value among public sector, private sector and multinational companies operating in India.

Since the government of India was planning to implement CSR (refer chapter 1, page 8 on Company Bill 2012), and CSR being a new concept in India, several large corporations, especially the public sector enterprises assigned responsibility of strategic CSR and Sustainable Development Goals under a Senior Manager/ Manager depending on the degree of involvement and budget allocated.

\subsection{Method of data collection and tools}

The study is both conceptual and empirical. The conceptual part of the study involve gathering information from secondary sources such as company reports, published annual reports, CSR reports, sustainability reports, websites, publications, newspapers, films and journals about various organizations, research papers and studying the CSR and sustainable development initiatives undertaken by the companies.

The study is empirical because it involves gathering of primary data from sample of companies selected for investigation with reference to strategic CSR. The research involves identifying respondents, gathering and recording information from respondents through interviews and questionnaires.

(a) Qualitative study

The research tools applied in qualitative study are: 
(i) Interview scheduling and one to one discussion with senior managers/managers responsible for CS/CSR and sustainable development initiatives using questionnaire 1 . The companies selected for personal interview were located in Delhi.

(ii) Observation and noting down information while discussing with the managers responsible for CS/CSR and sustainable development initiatives.

Through interaction, observation and in depth study of reading materials, researcher was able to obtain information and make an inference.

(b) Quantitative study

The research tools applied are:

Questionnaire 2 on strategic CSR based on Burke \& Logsdon's (1996) model, questionnaire 3 on responsibilities of companies with respect to Carroll's pyramid of CSR (1999) and the three components of CSR (charity, stewardship and environmental friendliness) were used. These questionnaires were already tested and validated in previously conducted studies. Questionnaires 2 and 3 were administered to 520 member companies of ASSOCHAM. The senior managers responsible for CS/CSR activities of these companies located far and wide were contacted by email.

The senior managers responsible for CS and CSR of those corporations located in Delhi were personally contacted by the researcher, and questionnaires administered. Almost all the Indian public sector enterprises have corporate office located in Delhi. The questionnaires are included in Annexure I.

\subsection{Sampling}

The current research adopted cluster sampling method to choose and group companies. In this study, the samples of companies were drawn from a list containing 
more than 300,000 member companies of Associated Chamber of Commerce and Industry of India (ASSOCHAM), the Indian chamber of commerce. These companies were classified under several clusters. Only those clusters of public sector enterprises, private sector and multinational companies undertaking some kind of CSRs and sustainable development initiatives were identified and selected in the sample.

Convenience sampling is applied to the three groups of clusters selected for the qualitative study.

Probability sampling (simple random sampling) method is applied to the selected three groups of clusters for quantitative study. In probability sampling, each company from the cluster group has equal chances of being selected, and the sample selected is a true representation of the cluster group. Probability sampling is used because the companies in the cluster groups are large and diverse; therefore, researcher believes that the samples selected are the unbiased representation of the cluster of companies (Bhat 2019).

(a) Samples for qualitative study

The qualitative study includes 43 companies for analyzing the case. The samples were drawn from New Delhi and surrounding areas (refer previous section). The tables 5, 6 and 7 given below provide sector-wise information on the 43 companies under qualitative CS and CSR study.

(b) Samples for quantitative study

The quantitative study includes 93 companies. The corporate headquarters of large business organizations are located in the cities of Mumbai and Delhi. The tables 8, 9 and 10 given below provide sector-wise information on the 93 companies under quantitative CSR study. 
Table 5: Qualitative study - Consolidated statement of global operations of multinational corporations (MNCs)

\begin{tabular}{|l|l|l|l|l|}
\hline Industry segment & $\begin{array}{l}\text { No. of } \\
\text { companies }\end{array}$ & $\begin{array}{l}\text { Revenue } \\
\text { (\$ Million) }\end{array}$ & $\begin{array}{l}\text { Net profit } \\
\text { (\$ Million) }\end{array}$ & $\begin{array}{l}\text { No. of } \\
\text { employees }\end{array}$ \\
\hline Manufacturing industry: & \multicolumn{5}{|l|}{} \\
\hline Chemical \& industrial products & 2 & 61047.477 & 4848 & 604000 \\
\hline Consumer products, food \& beverages, textiles, paper & 5 & 303789.303 & 39393.423 & 779981 \\
\hline Energy, power, oil \& gas, and capital goods & 5 & 276038.558 & 19813.588 & 752838 \\
\hline Precision tools \& engineering & 2 & 70364.340 & 2603.060 & 242893 \\
\hline Automobiles \& heavy vehicles & 1 & 146917 & 7155 & 181000 \\
\hline Pharmaceuticals & 1 & 40293.25 & 8648.275 & 99451 \\
\hline Computer, telecom hardware & 1 & 183609.762 & 27208 & 718163 \\
\hline Services industry: & 4 & & \\
\hline Warehousing, container \& transportation & \multicolumn{3}{|l|}{} & 435520 \\
\hline Hospitality & 1 & 70632.741 & 2861.185 & 30000 \\
\hline Computer software & 1 & 354.565 & 50.954 & 165572 \\
\hline Total & 2 & 99457.598 & 26132.892 \\
\hline
\end{tabular}

(Source: Annual Report 2012-2013, currency value as on 31 ${ }^{\text {st }}$ March 2013: INR1= $\$ 0.01842, € 1=\$ 1.2822, £ 1=\$ 1.5206, C H f 1=1.0538, ¥ 1=0.0106$, SEK1 $=\$ 0.1532)$

Consolidated statement on global operations of MNCs were used in the above table 5 since several MNCs did not publish a separate annual report on India or the Indian performance statements were merged with the Asian or regional reports. This could be due to low contribution from the Indian operations 
Table 6: Qualitative study - Consolidated statement of operations of Indian private companies (Indian private)

\begin{tabular}{|c|c|c|c|c|}
\hline Industry segment & $\begin{array}{l}\text { No. of } \\
\text { companies }\end{array}$ & $\begin{array}{l}\text { Revenue } \\
\text { (\$ Million) }\end{array}$ & $\begin{array}{l}\text { Net profit } \\
\text { (\$ Million) }\end{array}$ & $\begin{array}{l}\text { No. of } \\
\text { employees }\end{array}$ \\
\hline \multicolumn{5}{|l|}{ Manufacturing industry: } \\
\hline Chemical \& industrial products & 3 & 6558.775 & 295.607 & 145516 \\
\hline Real estate, construction, cement \& infrastructure & 2 & 2737.3967 & 201.894 & 11558 \\
\hline Consumer products, food \& beverages, textiles, paper & 1 & 8090.6431 & 1366.541 & 31000 \\
\hline Automobiles \& heavy vehicles & 2 & 6901.3457 & 470.05 & 20468 \\
\hline Steel & 1 & 7659.053 & 177.414 & 21000 \\
\hline Pharmaceuticals & 1 & 2141.7359 & 309.030 & 16500 \\
\hline \multicolumn{5}{|l|}{ Services industry: } \\
\hline Telecom \& internet & 1 & 14754 & 418 & 15563 \\
\hline Total & 11 & 48842.9494 & 2820.536 & 261605 \\
\hline
\end{tabular}

(Source: Annual Report 2012-2013, currency value as on 31 ${ }^{\text {st }}$ March 2013: \$1=INR54.29)

Table 7: Qualitative study - Consolidated statement of operations of Indian public sector enterprises (PSEs)

\begin{tabular}{|l|l|l|l|l|}
\hline Industry segment & $\begin{array}{l}\text { No. of } \\
\text { companies }\end{array}$ & $\begin{array}{l}\text { Revenue } \\
\text { (\$ Million) }\end{array}$ & $\begin{array}{l}\text { Net profit } \\
\text { (\$ Million) }\end{array}$ & $\begin{array}{l}\text { No. of } \\
\text { employees }\end{array}$ \\
\hline Manufacturing industry: & \multicolumn{5}{|l|}{} \\
\hline Real estate, construction, cement \& infrastructure & 1 & 538.49 & 129.0501 & 800 \\
\hline Energy, power, oil \& gas, and capital goods & 7 & 129418.55 & 8164.6695 & 459849 \\
\hline Total & 8 & 129957.04 & 8293.7196 & 460649 \\
\hline
\end{tabular}

(Source: Annual Report 2012-2013, currency value as on 31 ${ }^{\text {st }}$ March 2013: \$1=INR54.29)

The list containing names of companies are presented in Annexure III. 
Table 8: Quantitative study- Consolidated statement of global operations of multinational corporations (MNCs)

\begin{tabular}{|c|c|c|c|c|}
\hline Industry segment & $\begin{array}{l}\text { No. of } \\
\text { companies }\end{array}$ & $\begin{array}{l}\text { Revenue } \\
\text { (\$ Million) }\end{array}$ & $\begin{array}{l}\text { Net profit } \\
\text { (\$ Million) }\end{array}$ & $\begin{array}{l}\text { No. of } \\
\text { employees }\end{array}$ \\
\hline \multicolumn{5}{|l|}{ Manufacturing industry: } \\
\hline Chemical \& industrial products & 3 & 57267.15 & 5977 & 117600 \\
\hline Consumer products, food \& beverages & 3 & 228590.2 & 30497.8 & 587600 \\
\hline Energy, power, oil \& gas, and capital goods & 7 & 287619.2 & 19740.71 & 779959 \\
\hline Precision tools \& engineering & 1 & 9754 & 160.05 & 45220 \\
\hline Automobiles \& heavy vehicles & 3 & 415887.3 & 20477.4 & 560000 \\
\hline Steel & 1 & 24828 & $(1357)$ & 35905 \\
\hline Computer, telecom hardware & 6 & 290965 & 32377 & 959774 \\
\hline \multicolumn{5}{|l|}{ Services industry: } \\
\hline Banking, insurance \& finance & 1 & 9397 & 1488.3 & 19000 \\
\hline Warehousing, container $\&$ transportation & 1 & 70674 & 2683 & 435520 \\
\hline Hospitality & 1 & 356 & $(51)$ & 22066 \\
\hline Computer software & 1 & 11603 & 2565 & 276196 \\
\hline Telecom \& internet & 2 & 68296 & 901.9 & 96272 \\
\hline Total & 30 & 1475236.85 & 115460.16 & 3935112 \\
\hline
\end{tabular}

(Source: Annual Report 2012-2013, currency value as on 31 ${ }^{\text {st }}$ March 2013: \$1=INR54.29)

Consolidated statement on global operations of MNCs were used in the above table 8 since several MNCs did not publish a separate annual report on India or the Indian performance statements were merged with the Asian or regional reports. This could be due to low contribution from the Indian operations 
Table 9: Quantitative study - Consolidated statement of operations of Indian private companies (Indian private)

\begin{tabular}{|c|c|c|c|c|}
\hline Industry segment & $\begin{array}{l}\text { No. of } \\
\text { companies }\end{array}$ & $\begin{array}{l}\text { Revenue } \\
\text { (\$ Million) }\end{array}$ & $\begin{array}{l}\text { Net profit } \\
\text { (\$ Million) }\end{array}$ & $\begin{array}{l}\text { No. of } \\
\text { employees }\end{array}$ \\
\hline \multicolumn{5}{|l|}{ Manufacturing industry: } \\
\hline Chemical \& industrial products & 4 & 7240.11 & 947.38 & 157358 \\
\hline Real estate, construction, cement \& infrastructure & 3 & 4413 & 348.3 & 23395 \\
\hline Consumer products, food \& beverages, textiles, paper & 3 & 9590 & 1477.53 & 36759 \\
\hline Energy, power, oil \& gas, and capital goods & 3 & 17976 & 1198 & 31710 \\
\hline Precision tools \& engineering & 1 & 577 & 7.40 & 710 \\
\hline Automobiles \& heavy vehicles & 3 & 14989.5 & 1088 & 59786 \\
\hline Mining \& minerals trading & 1 & 4670 & 647 & 60000 \\
\hline Steel & 3 & 10482 & 364 & 17400 \\
\hline Pharmaceuticals & 2 & 2794.4 & 386.52 & 54720 \\
\hline \multicolumn{5}{|l|}{ Services industry: } \\
\hline Banking, insurance \& finance & 2 & 493.5 & 40.18 & 3500 \\
\hline Telecom \& internet & 1 & 14793 & 418 & 25400 \\
\hline Total & 26 & 88018.51 & 6922.31 & 470738 \\
\hline
\end{tabular}

(Source: Annual Report 2012-2013, currency value as on 31 ${ }^{\text {st }}$ March 2013: \$1=INR54.29) 
Table 10: Quantitative study - Consolidated statement of operations of Indian public sector enterprises (PSEs)

\begin{tabular}{|c|c|c|c|c|}
\hline Industry segment & $\begin{array}{l}\text { No. of } \\
\text { companies }\end{array}$ & $\begin{array}{l}\text { Revenue } \\
\text { (\$ Million) }\end{array}$ & $\begin{array}{l}\text { Net profit } \\
\text { (\$ Million) }\end{array}$ & $\begin{array}{l}\text { No. of } \\
\text { employees }\end{array}$ \\
\hline \multicolumn{5}{|l|}{ Manufacturing industry: } \\
\hline Chemical \& industrial products & 5 & 15974 & 2200 & 43934 \\
\hline Real estate, construction, cement \& infrastructure & 2 & 548 & 133 & 1144 \\
\hline Consumer products, food \& beverages, textiles, paper & 3 & 548 & 21.23 & 12628 \\
\hline Energy, power, oil \& gas, and capital goods & 9 & 209512 & 9229 & 167449 \\
\hline Mining \& minerals trading & 5 & 24945 & 4503.23 & 19477 \\
\hline Steel & 1 & 9090 & 400 & 101878 \\
\hline \multicolumn{5}{|l|}{ Services industry: } \\
\hline Banking, insurance $\&$ finance & 6 & 354591 & 3979 & 127378 \\
\hline Warehousing, container \& transportation & 3 & 1961 & 199 & 6657 \\
\hline Trade \& exhibitions & 2 & 5639 & 52.5 & 1606 \\
\hline Engineering project consultancy & 1 & 462 & 116 & 77 \\
\hline Total & 37 & 623269.48 & 20832.68 & 482228 \\
\hline
\end{tabular}

(Source: Annual Report 2012-2013, currency value as on 31 ${ }^{\text {st }}$ March 2013: \$1=INR54.29)

The list containing names of companies are presented in Annexure III. 


\subsection{Methods of analyses}

The methods of analyses of qualitative and quantitative studies are given below:

(a) Qualitative study

Qualitative research may be classified as "ethnography, case studies, life history, narrative inquiry, field studies, grounded theory, document studies, naturalistic inquiry, observational studies, interview studies and descriptive studies. Qualitative research design in the social sciences stem from traditions in anthropology, sociology, in which the philosophy emphasizes the phenomenological basis of the study, the elaborate description of the 'meaning' of phenomena from the perspectives of people or culture under examination" (Ridenour \& Newman 2008).

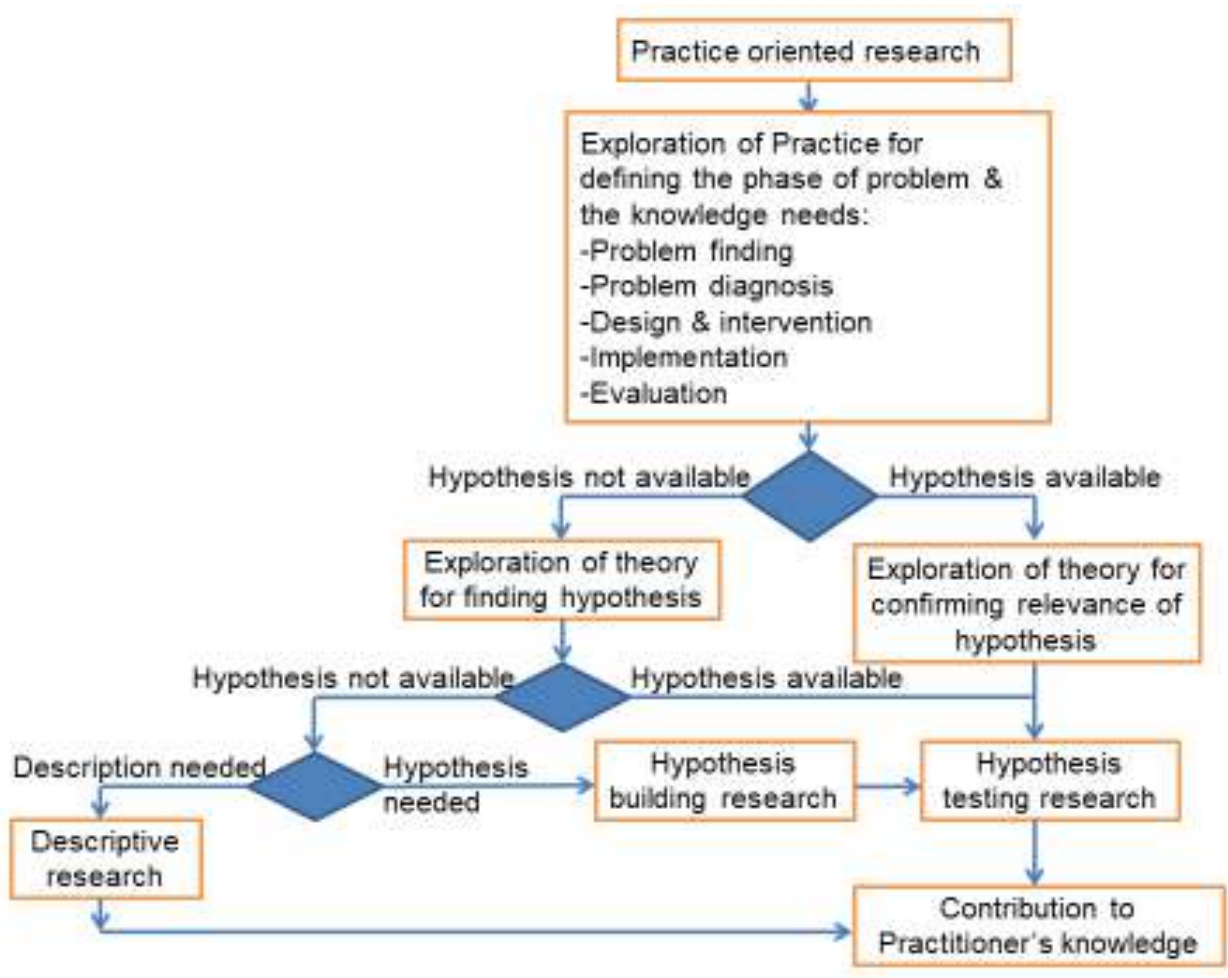

Figure 14: Deciding on type of practice-oriented research (Source: Dul \& Hak 2008) 
Practice-oriented research is used in this qualitative study. This is because practice-oriented research aims at contributing to knowledge of specific practitioner responsible for a specific practice. A practice is the real life situation wherein practitioner has a responsibility - formal or informal, for a specific practice (Dul \& Hak 2008). Practice oriented research is based on management practice; and is a "systematic, methodologically correct, collection and evaluation of observable facts in the organization by which it is proven that success occurs as a result of an intervention. The criterion for success of practice oriented research is whether an empirically correct conclusion about a practical object of study is reached" (Dul \& Hak 2008).

The qualitative study consists of descriptive practice oriented research related to:

- Researcher's experience of working in the industry, and

- $\quad$ Literature review on areas related to CS \& CSR initiatives among companies operating in India

- Interviewing, observing and recording information on sustainable development \& CS/CSR initiatives from practising managers of companies.

Researcher's experience in the industry:

Researcher undertook several discretionary CSR programmes at local level while employed in the marketing department of the Indian pharmaceutical industry during the late 1980 s and 1990s. These socially responsible programmes were undertaken in leading pharmaceuticals companiesAlembic, Pfizer and Astra Zeneca in India. Major activities were related to organizing health camps along with the medical professionals, supporting patients in rural and remote areas by means of donating free samples of medicines. Whenever patients from poor socio-economic background were referred to the researcher with prescriptions from the medical professionals, 
the researcher obliged them with free samples, irrespective of the cost of the medicines. These could be expensive anti-infective therapy for short term treatment or chronic therapy medications. These events were recorded in the memory of researcher while working in the healthcare and pharmaceuticals industry for two decades.

Interviewing CS \& CSR managers:

Managers undertaking sustainable development and CS/CSR initiatives were identified and interviewed using questionnaire 1 wherein specific information on sustainable development and CSR initiatives were gathered, compared and contrasted with the information obtained from other interviews. The questions asked were specific and related to sustainable development and CSR initiatives of the company. The same sets of questions were asked to corporate sustainability/CSR managers in order to ensure continuity. Open ended questions also were used as a part of qualitative study.

The information gathered were analyzed, verified with company documents such as annual reports, CSR and sustainability reports of the organizations. Data analysis in qualitative study is also called 'pattern matching,' wherein two or more pattern are compared through observation or visual inspection in order to determine if the patterns match (Dul \& Hak 2008).

The steps in qualitative data analysis are:

(i) Preparation and organization of collected data

(ii) Data reduction by identifying themes and creating categories, and

(iii) Presenting qualitative data in narrative form, tables or diagrams.

Riessman (1993, p.10) suggests five "phases" of qualitative research as follows: Attending, telling, transcribing, analyzing, and communicating (table 11). 
Table 11: Phases of qualitative research (Source: Cropley 2019, Riessman 1993)

\begin{tabular}{|c|c|c|}
\hline Focus & Phase & Content \\
\hline \multirow{3}{*}{ Respondents } & Attending & $\begin{array}{l}\text { Respondents organize and order their own } \\
\text { experience and store a record in their minds }\end{array}$ \\
\hline & Telling & $\begin{array}{l}\text { Respondents select relevant aspects of their } \\
\text { experience to narrate to the interviewer }\end{array}$ \\
\hline & $\begin{array}{l}\text { Transcribing } \\
\text { (first step) }\end{array}$ & $\begin{array}{l}\text { Respondents narrate their experiences to the } \\
\text { researcher }\end{array}$ \\
\hline \multirow{3}{*}{ Researcher } & $\begin{array}{l}\text { Transcribing } \\
\text { (second step) }\end{array}$ & $\begin{array}{l}\text { The researcher records narratives of each one of } \\
\text { the respondents }\end{array}$ \\
\hline & Analyzing & $\begin{array}{l}\text { The researcher "makes sense" out of each } \\
\text { narrative and discerns the general picture }\end{array}$ \\
\hline & $\begin{array}{l}\text { Communication } \\
\text { (first step) }\end{array}$ & $\begin{array}{l}\text { The researcher writes a report and makes it } \\
\text { available to knowledgeable readers }\end{array}$ \\
\hline \multirow[t]{2}{*}{ Readers } & $\begin{array}{l}\text { Communication } \\
\text { (second step) }\end{array}$ & The report is read by knowledgeable readers \\
\hline & Validation & $\begin{array}{l}\text { Readers form an impression of the report's } \\
\text { contents and assess its usefulness }\end{array}$ \\
\hline
\end{tabular}

(b) Quantitative study

Before carrying out the research work, pilot questionnaires were carefully drafted and distributed among professionals for the purpose of correcting possible errors and allowing further insight into the contents of the questionnaires. These professionals identified were tutors of management schools and professional managers from the industry who have practical and academic experience related to CSR.

Likert scale type questionnaires were used in obtaining responses from respondents. The questionnaires consisted of both open ended and close 
ended questions. One set of questionnaires (questionnaire 2) to measure dimensions of strategic CSR developed and validated by Burke \& Logsdon (1996). These dimensions centrality, specificity, proactivity, visibility and voluntarism were evaluated against value creation on a 5-point scale measuring $0 \%, 25 \%, 50 \%, 75 \%$ and $100 \%$ agreement. The second set of questionnaires (questionnaire 3) measuring Corporate responsibilities of companies were evaluated through Carroll's (1991) pyramid; Lawrence, Weber \& Post's (2005) principles of charity and stewardship and environmental responsibility. These were evaluated against value creation on a 5 -point scale measuring $0 \%, 25 \%, 50 \%, 75 \%$ and $100 \%$ agreement (given in Annexure I).

These above questionnaires were tested among multinational companies, private sector companies and public sector enterprises operating in India.

\subsection{Variables}

The independent variables described under dimensions of strategic CSR are: centrality, specificity, proactivity, visibility and voluntarism. The independent variables described under corporate responsibilities are: economic responsibility, legal responsibility, ethical responsibility, philanthropy, charity, stewardship and environmental friendliness. The dependent variable is value creation among corporations operating in India.

The independent variables, dependent variables and control variables in relation to CSR dimensions, corporate responsibilities are give below in tables 12,13 and 14 respectively. 
Table 12: Independent variables

\begin{tabular}{|c|c|}
\hline \multicolumn{2}{|c|}{ Dimensions of strategic CSR } \\
\hline \multirow{3}{*}{$\begin{array}{l}\text { Centrality } \\
\text { (discussed under } \\
\text { section } 2.3 \text { and } \\
\text { tables 2,3 \& 4) }\end{array}$} & $\begin{array}{l}\text { Collaborating with community projects as a part of corporate } \\
\text { policy }\end{array}$ \\
\hline & Environmental protection as a mission of the company \\
\hline & $\begin{array}{l}\text { Support by the top management towards solving societal } \\
\text { issues as a part of mission }\end{array}$ \\
\hline $\begin{array}{l}\text { Specificity } \\
\text { (discussed under } \\
\text { section } 2.3 \text { and } \\
\text { tables } 2,3 \text { \& 4) }\end{array}$ & Fulfilling social objectives as a part of mission statement \\
\hline \multirow{3}{*}{$\begin{array}{l}\text { Proactivity } \\
\text { (discussed under } \\
\text { section } 2.3 \text { and } \\
\text { tables 2, } 3 \text { \& 4) }\end{array}$} & $\begin{array}{l}\text { Scanning social environment to evaluate the compliance of } \\
\text { firm with expectations of the society }\end{array}$ \\
\hline & Proactively developing corporate compliance mechanisms \\
\hline & Proactively adopting policies meeting social expectations \\
\hline \multirow{2}{*}{$\begin{array}{l}\text { Visibility (discussed } \\
\text { under section } 2.3 \\
\text { and tables } 2,3 \& 4 \text { ) }\end{array}$} & Improving image of the organization \\
\hline & To be visible in the media \\
\hline \multirow{3}{*}{$\begin{array}{l}\text { Voluntarism } \\
\text { (discussed under } \\
\text { section } 2.3 \text { and } \\
\text { tables 2, } 3 \text { \& 4) }\end{array}$} & $\begin{array}{l}\text { The company participates in social action programmes to } \\
\text { voluntarily fulfil legal obligations }\end{array}$ \\
\hline & The company does not focus on obtaining tax benefits \\
\hline & The company supports social cause \\
\hline \multicolumn{2}{|c|}{ Corporate responsibilities } \\
\hline \multirow{4}{*}{$\begin{array}{l}\text { Economic } \\
\text { responsibility } \\
\text { (discussed under } \\
\text { section } 2.4 \text { ) }\end{array}$} & Goal of organization in terms of generating profits \\
\hline & Social responsibility of the company by keeping the costs low \\
\hline & Focusing on maximizing returns to shareholders \\
\hline & $\begin{array}{l}\text { Ability of the company to manage economic function without } \\
\text { compromising on social contributions }\end{array}$ \\
\hline
\end{tabular}




\begin{tabular}{|c|c|}
\hline \multirow{3}{*}{$\begin{array}{l}\text { Legal responsibility } \\
\text { (discussed under } \\
\text { section } 2.4 \text { ) }\end{array}$} & Complying with all rules and regulations \\
\hline & $\begin{array}{l}\text { Willingness to operate within the legal framework of the } \\
\text { society }\end{array}$ \\
\hline & $\begin{array}{l}\text { Commitment of the companies in adhering to rules \& } \\
\text { regulations }\end{array}$ \\
\hline \multirow{4}{*}{$\begin{array}{l}\text { Ethical } \\
\text { responsibility } \\
\text { (discussed under } \\
\text { section } 2.4 \text { ) }\end{array}$} & Commitment of the organization in adhering to ethical norms \\
\hline & Company being right, fair and just in its actions \\
\hline & Avoid doing harm to the citizen and society \\
\hline & Does not compromise ethics for economic gains \\
\hline \multirow{3}{*}{$\begin{array}{l}\text { Philanthropy } \\
\text { (discussed under } \\
\text { section 2.4) }\end{array}$} & Contributing resources to the community \\
\hline & Aiming for community betterment \\
\hline & Company actively promoting voluntarism \\
\hline \multirow{4}{*}{$\begin{array}{l}\text { Charity principle } \\
\text { (discussed under } \\
\text { section } 2.5 \text { ) }\end{array}$} & Obligation of the company to the needy persons in the society \\
\hline & Charity initiatives of the company \\
\hline & Volunteering efforts of the company towards the society \\
\hline & Contributions of the company towards charity \\
\hline \multirow{4}{*}{$\begin{array}{l}\text { Stewardship } \\
\text { (discussed under } \\
\text { section } 2.5 \text { ) }\end{array}$} & Obligation of the company towards the society \\
\hline & $\begin{array}{l}\text { Concern of the company towards those affected by the } \\
\text { decisions and actions of the company }\end{array}$ \\
\hline & $\begin{array}{l}\text { Ability of the company to manage the interest of various } \\
\text { society groups }\end{array}$ \\
\hline & Interdependence of business and society \\
\hline \multirow{3}{*}{$\begin{array}{l}\text { Environmental } \\
\text { friendliness } \\
\text { (discussed under } \\
\text { section 2.6) }\end{array}$} & Ability of the company to take care of the natural environment \\
\hline & $\begin{array}{l}\text { Ability of the company to contribute to maintaining and up- } \\
\text { keeping the natural environment }\end{array}$ \\
\hline & $\begin{array}{l}\text { Effort of the company in minimizing waste and initiating } \\
\text { recycling of waste }\end{array}$ \\
\hline
\end{tabular}


Table 13: Dependent variable

\begin{tabular}{|l|l|}
\hline \multicolumn{2}{|l|}{ Value creation } \\
\hline Creating value for & Ability of the company to influence decisions of its customers \\
\cline { 2 - 2 } the firm & Ability of the company to create new customers \\
\cline { 2 - 2 } $\begin{array}{l}\text { (discussed in } 2.3 \\
\text { and Tables } 3 \& 4)\end{array}$ & Ability of the company to develop new products \& services \\
\cline { 2 - 2 } & Ability of the company to enter into new markets \\
\hline
\end{tabular}

Table 14: Control variables

\begin{tabular}{|c|c|}
\hline Companies & Definitions and grouping of companies \\
\hline $\begin{array}{l}\text { Multinational } \\
\text { companies } \\
\text { operating in India }\end{array}$ & $\begin{array}{l}\text { All companies operating in India, with at least } 51 \% \text { of business } \\
\text { generated from overseas markets, undertaking some kind of } \\
\text { CSR and sustainable development activities related to } \\
\text { development of economic, social and environment in India }\end{array}$ \\
\hline $\begin{array}{l}\text { Private sector } \\
\text { companies of } \\
\text { Indian origin }\end{array}$ & $\begin{array}{l}\text { All types of Indian companies originated and registered in India, } \\
\text { held by Indian entrepreneurs or with majority Indian equity } \\
\text { holding. There companies undertake some kind of CSR activities } \\
\text { or sustainable development initiatives towards economic, social } \\
\text { and environment in India }\end{array}$ \\
\hline $\begin{array}{l}\text { Public Sector } \\
\text { Enterprises owned } \\
\text { by Government of } \\
\text { India }\end{array}$ & $\begin{array}{l}\text { All enterprises established by the Government of India with the } \\
\text { government held equity holding of more than } 50 \% \text {. These } \\
\text { companies are regulated under 'Department of Public } \\
\text { Enterprises', undertaking CSR and sustainable initiatives in India }\end{array}$ \\
\hline
\end{tabular}

The control variables influence factors that are associated with strategic CSR. The control variables are types of firms based on industry, origin, size, business operations, revenue generated and profitability of firms, number of employees, etc. 
In order to assess an association between dependent and independent variables, (tables 12 \& 13) regression analysis was undertaken. Linear multiple regression analysis was applied to evaluate the outcome (dependent) variable - value creation with multiple predictors of dimensions of strategic CSR (centrality, specificity, proactivity, voluntarism and visibility) the four categories of corporate responsibilities (economical, legal, ethical and philanthropy) and the three components of CSR (charity, stewardship and environmental friendliness) among the three groups of companies - the MNCs, the Indian private sector and the public sector enterprises.

The regression model 1 (tables 26, 28 \& 30 under Chapter 6) is tested for normality, linearity, to detect heteroscedasticity, autocorrelation and multicollinearity. Factor analysis, a statistical application of reducing the number of unobserved variables called factors is undertaken. Factor analysis has application in several areas of research where large amounts of data are involved in the analysis (figure 20 in Chapter 6). Factor analysis allows estimating the population level (i.e., unobserved) structure underlying the variations of observed variables and their interrelationships (Gorsuch 1983; Kim \& Mueller 1978). The factor analysis intimately involves the questions of validity; and it is at the heart of measurements of psychological constructs" (Nunnally 1978, p112-113). Factor analysis was undertaken to bring down the Variance Inflation Factor to the required value $(\mathrm{VIF}<10)$, increase Tolerance greater than 0.5 and Condition Index $<15$. Regression model 2 (tables 44, 46 and 48 under Chapter 6) was undertaken and analysis done. 


\subsection{Validity and reliability}

Qualitative study

Validity is the extent to which the data and interpretation of data are credible.

According to Creswell (2007), the eight strategies to ensure validity or accuracy of qualitative data are:

- $\quad$ "Prolong engagement and persistent observation in order to build trust and to interpret misinformation or distortions in communication;

- $\quad$ Detailed description ensures that the phenomena studied is included so that others can draw similar conclusions;

- $\quad$ Triangulation refers to use of multiple data sources in order to build a complete picture of the phenomena;

- Member checking permits the researcher to present conclusions and findings to the original participant in order to check and verify that their beliefs are depicted correctly;

- Clarifying researcher's biases by acknowledging preconceptions or assumptions that could influence the conclusions of the study;

- $\quad$ Peer reviewing in order to check the research process;

- $\quad$ An external auditor may review the research and confirm overall logic, coherence and consistency of research;

- $\quad$ Researcher refines the initial hypotheses until all cases fit in inorder to eliminate exceptions and outliers" (Creswell 2003).

\section{Quantitative study}

According to Knight (2002), in order to achieve the requirements of validity, a number of procedures were carried out in this research. Firstly, the research involved undertaking an extensive review of literature, reviewing and investigating multiple sources of information in order to identify and discuss all aspects or issues related to 
the research. Data collection method using questionnaires, supported by structured interviews were undertaken in this research. Secondly, the questionnaires used in this research was piloted and pre-tested before it was used for data collection.

Reliability of data collection method

In relation to the data collection methods used in this research (i.e., intervieweradministered questionnaires and structured interviews), a number of factors that are likely to threaten reliability. These are: subject error, subject bias, observer-caused effects and observer bias (Saunders et al. 2000; McKinnon 1988).

Subject error refers to tendency of the respondents to provide responses that differ from true facts. This is most likely to happen if the researcher does not choose an appropriate time during the day to collect data (Saunders et al. 2000). As an illustration, if the data is collected early at the beginning of a working day, respondents may be keen to respond. Whereas, collecting data at the end of a working day is likely to drive respondents to provide irrational responses because they suffer fatigue resulting from work load which subsequently would affect the reliability of the data collected. To overcome this threat, the researcher identified 'neutral' times for data collection when respondents were believed to be neutral in their feelings (e.g. during mid day).

Subject bias refers to tendency of respondents in providing responses that differ from true facts because they are obliged to do so or due to the firm's policy which restricts publishing sensitive or confidential information (Saunders et al. 2000). To overcome this threat, researcher assured the respondents that the data collected from the questionnaires and the interviews shall be kept confidential and anonymous; and shall not be used for any purposes other than this research. Subject bias could also be reduced if the researcher has good background knowledge on the selected topic. 
Observer-caused effects are those effects which result from the observer's (i.e., the researcher's) presence in the phenomenon under study; and these are likely to influence respondent's behavior, conversation, and data which he/she provides. This type of threat occours when a role attributed to the researcher by the respondents is such that it drives them to change their normal behavior (McKinnon 1988). To overcome this threat, the questionnaires and interviews were preceded by opening statements and clarification of the role of the researcher in order to build confidence and trust between the researcher and the respondents (Saunders et al. 2000).

Observer bias is "the tendency to observe a phenomenon in a manner that differs from true observation in some consistent fashion" (Simon \& Burstein 1985). This may be due to the fact that researcher sees, hears or understands and then records answers of the respondent based on researcher's own interpretation and perception of the phenomenon. In order to overcome this reliability threat, the research involved meticulously recording answers from the respondents by note-taking the exact answers during an interview (McKinnon 1988). Accordingly, the benefit of notetaking during interviews is that the factual data, the researcher's perception and interpretation are reproduced exactly as it is. This is likely to reduce threat of observer bias on the data collection method resulting in reliability of information.

Reliability of data in the quantitative study was tested using Cronbach alpha (table 49 under Chapter 6). The Cronbach alpha test reported in the study was above 0.70 which is in the acceptable range for analysis. The data were analyzed using SPSS 20 software.

\subsection{Comparison of current methodology with that of prior studies}

A comparison of methodologies used in all the three studies - the present study with that of the studies conducted by Aupperele (1983) and Husted \& Allen (2007) is given in table 15 below 
Table 15: Comparison of present methodology with that of previous similar studies

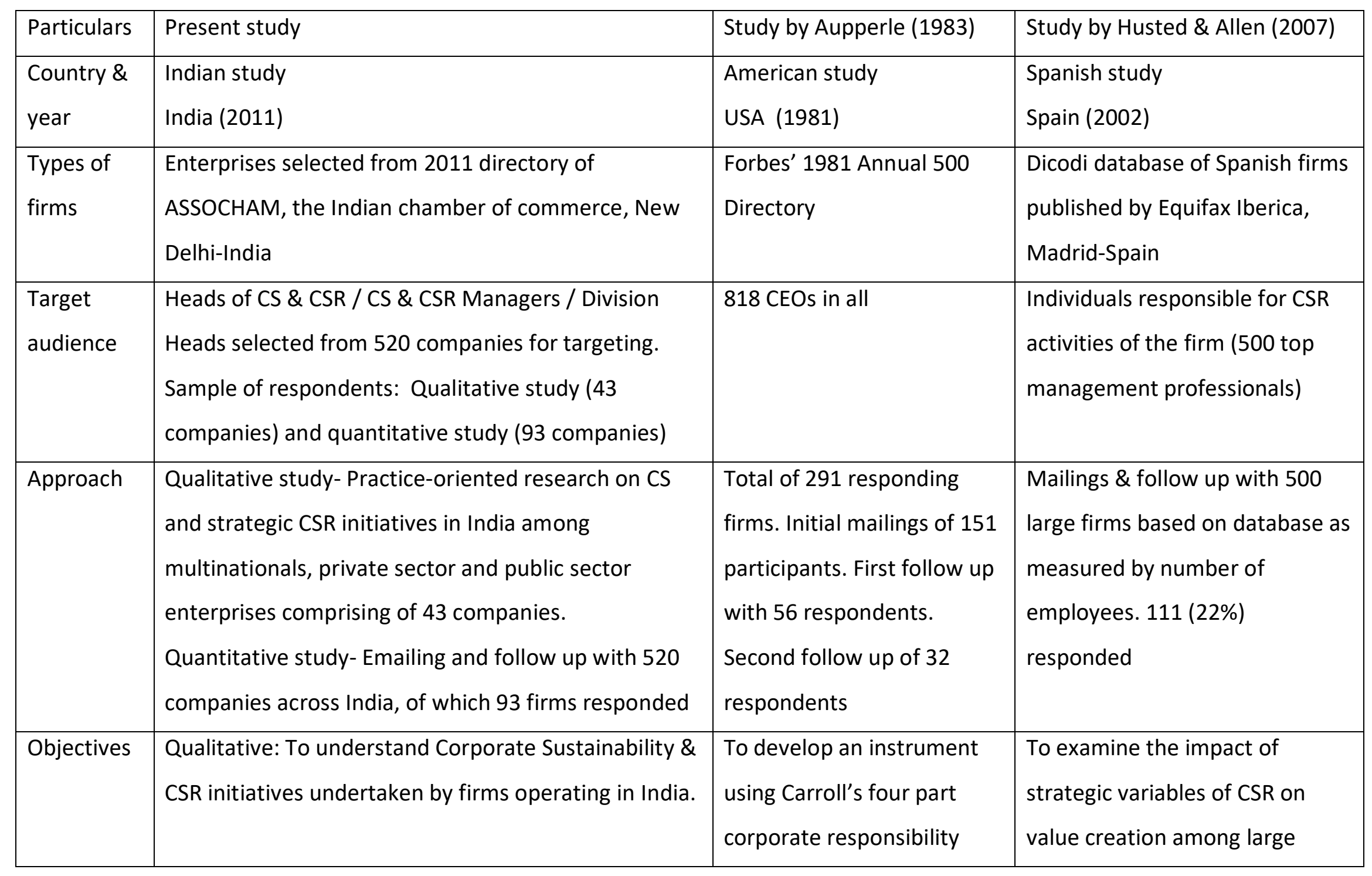




\begin{tabular}{|c|c|c|c|}
\hline & $\begin{array}{l}\text { Quantitative: To examine dimensions of strategic CSR, } \\
\text { Carroll's four corporate responsibilities and three } \\
\text { components of CSR on value creation among MNCs, } \\
\text { private \& public sector companies in India }\end{array}$ & $\begin{array}{l}\text { model. Test the model } \\
\text { among firms }\end{array}$ & Spanish firms \\
\hline Method & $\begin{array}{l}\text { Mixed sequential exploratory model (Qualitative } \\
\text { study followed by quantitative study) } \\
\text { Qualitative: Interview technique, observation \& } \\
\text { recording of information. Study undertaken through } \\
\text { practice-oriented research. Thematic analysis } \\
\text { undertaken on CS/CSR activities of the firms. } \\
\text { Quantitative: Likert scale instrument was used to } \\
\text { measure the variables under study. Dependent } \\
\text { variable- value creation. Independent variables- } \\
\text { dimensions of strategic CSR, Carroll's four corporate } \\
\text { responsibilities and the three components of CSR. } \\
\text { Types of organizations were control variables. } \\
\text { Multiple linear regression1 was performed. Factor } \\
\text { analysis was performed with varimax rotation. } \\
\text { Multiple linear regression2 was performed. }\end{array}$ & $\begin{array}{l}117 \text { CSR statements were } \\
\text { classified into } 2 \text { categories - } \\
\text { concern for society and } \\
\text { concern for economic } \\
\text { performance. } \\
\text { Questionnaire used were } \\
\text { general and avoided } \\
\text { questions that gave non } \\
\text { response or inappropriate } \\
\text { response from firms. } \\
\text { Factor analysis was } \\
\text { performed. First analysis } \\
\text { was N-factor, principal } \\
\text { factor analysis with varimax } \\
\text { rotation }\end{array}$ & $\begin{array}{l}\text { Likert scale instrument to } \\
\text { measure variables of value } \\
\text { creation-centrality, proactivity, } \\
\text { visibility, appropriability and } \\
\text { voluntarism. } \\
\text { Ordinary Least Square } \\
\text { regression analysis. Dependent } \\
\text { variable-value creation. } \\
\text { Independent variable-centrality, } \\
\text { proactivity, visibility, } \\
\text { appropriability \& voluntarism. } \\
\text { Firm size, risk and industry were } \\
\text { controls. }\end{array}$ \\
\hline
\end{tabular}




\begin{tabular}{|c|c|c|c|}
\hline Results & $\begin{array}{l}\text { Qualitative: Practice oriented research among } 43 \\
\text { companies were recorded and analyzed on the type } \\
\text { of CS and/or CSR initiatives undertaken by firms. The } \\
\text { overall relative performance of CS/CSR among the } \\
\text { firms were in the order PSEs > Indian private > MNCs. } \\
\text { Quantitative: Among MNCs operating in India, } \\
\text { centrality, proactivity, visibility, legal responsibility, } \\
\text { philanthropy and environmental friendliness were } \\
\text { significant in creating value. } \\
\text { In the Indian private sector, all the independent } \\
\text { variables (centrality, specificity, proactivity, visibility, } \\
\text { voluntarism, economic, legal, ethical, philanthropy, } \\
\text { charity, stewardship and environmental friendliness) } \\
\text { were significant in creating value. } \\
\text { Among the PSEs, proactivity, visibility, voluntarism, } \\
\text { economic, legal, ethical and philanthropy were } \\
\text { significant in creating value. }\end{array}$ & $\begin{array}{l}\text { Factor loading of } 80 \\
\text { statements confirm that } 59 \\
\text { of the } 80 \text { statements had } \\
\text { loading greater than } 0.40 \\
\text { on one of the three factors. }\end{array}$ & $\begin{array}{l}\text { Only three of the five variables } \\
\text { (visibility, appropriability and } \\
\text { voluntarism) are related to value } \\
\text { creation whereas centrality and } \\
\text { proactivity were not perceived } \\
\text { by Spanish firms in creating } \\
\text { value. }\end{array}$ \\
\hline
\end{tabular}




\section{CHAPTER 5}

CORPORATE SUSTAINABILITY \& CSR INITIATIVES IN THE INDIAN CORPORATE SECTOR (QUALITATIVE STUDY)

\subsection{Introduction to Corporate sustainability}

(i) Definitions

Corporate sustainability (CS) is the ability of corporations to respond to their short term needs without compromising the ability to meet the long term needs (Bansal \& DesJardine 2015). Corporate sustainability is defined as "corporate response with a profit motive responding to social and environmental issues created by primary and secondary activities in an organization" (Salzmann et al. 2005). Corporate sustainability is "a business activity that creates long-term shareholder value by appreciating opportunities and containing risks caused by social, economic and environmental developments" (Dow Jones Sustainability Index 2009).
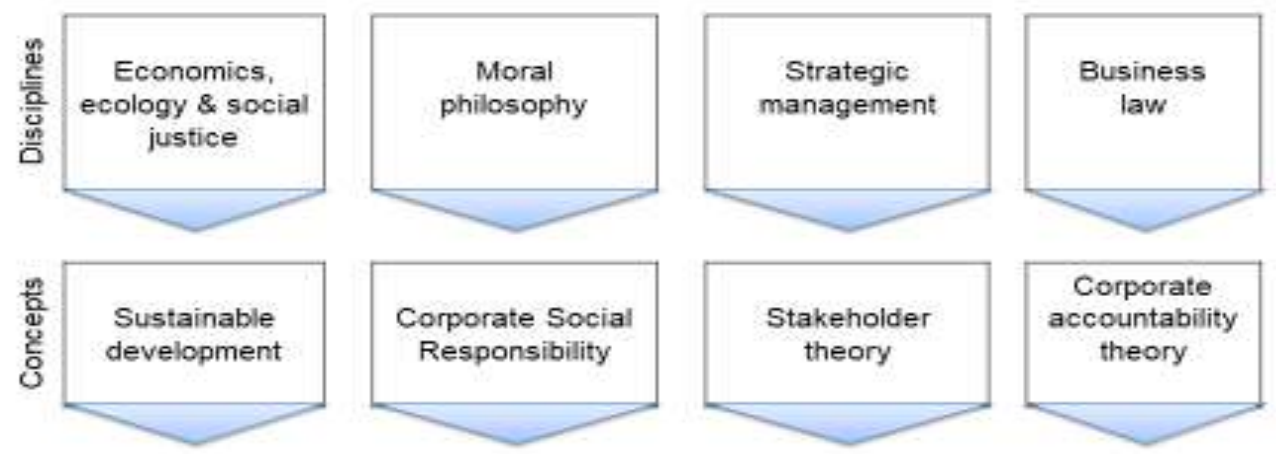

Corporate accountability theory
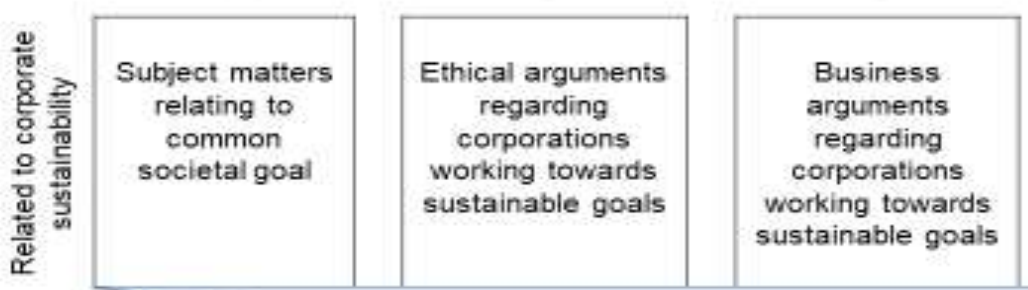

Ethical arguments regarding sustainability reporting by companies

Corporate Sustainability

Figure 15: Evolution of Corporate sustainability (Source: Wilson 2003) 
Sustainable corporations are expected to contribute to economic development, environmental protection and societal development, in addition to making profits for the organization. "Corporate sustainability has evolved from the four concepts of management- sustainable development, corporate social responsibility, stakeholder theory and corporate accountability. Corporate sustainability recognizes corporate growth and profitability along with social responsibility and sustainability" (Wilson 2003) as depicted in figure 15 above.

(ii) Dimensions of Corporate sustainability

The four dimensions of sustainable development are economic, social, environmental and cultural (UNESCO 2019) which are balanced and linked to each other with a goal of pursuing an enhanced quality of life. The four dimensions of corporate sustainability are economic, social, environmental and corporate identity (Chow \& Chen 2012, Lee \& Saen 2012, Simoes \& Sebastiani 2017).

Economic dimension refers to creation of competitiveness, wealth creation and sustainment over a period of time

Social dimension refers to the social value towards employees and society with regard to social equality, work opportunity, service to community and quality of wellbeing of all stakeholders.

Environmental dimension refers to safeguarding the environment, reducing the environmental impacts through business operations or processes and focusing on efficient environment friendly methods and strategies.

Corporate identity refers to the values of the organization, goals, objectives, vision, mission, key result areas, positive corporate image, activities and beliefs of the organization both short term and long term. 


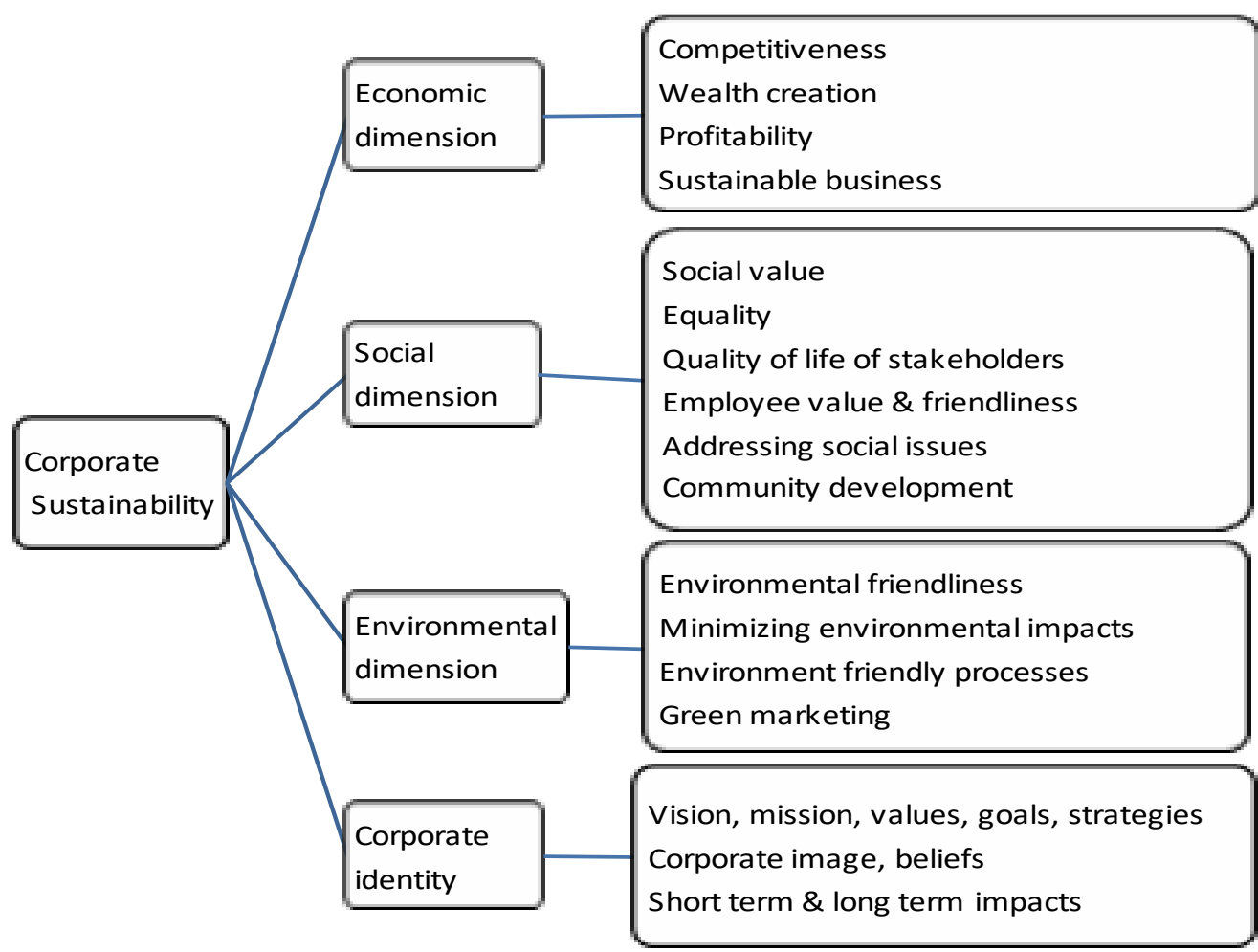

Figure 16: Dimensions of corporate sustainability

(Source: Adapted from Chow \& Chen 2012, Lee \& Saen 2012)

(iii) Integrating sustainability in business operations

Integration of sustainability into core business operation is the most important challenge of business today, as confirmed by $62 \%$ respondents and reported in the GlobeScan Sustainable Business Survey 2013 undertaken among 700 corporate executives. It has also been reported that only one out of five companies has completely integrated sustainability into its business operations. $21 \%$ of the respondents reported that their company is in close to full integration, whereas $51 \%$ of the respondents stated that their company is halfway to integrate and $22 \%$ reported as getting started for integration. The engagement between the sustainability functions and corporate functions in an organization such as investor relations, human resources, R\&D, marketing and finance remains low and is a concern (37\% engaged with investor relations, $34 \%$ of engaging with human resources, $32 \%$ engaged in the R\&D, $28 \%$ engaged in the marketing and $16 \%$ with the 
finance). High level of engagement has been observed amongst the sustainability function with the corporate communication function (75\%), public affairs (66\%), supply chain (64\%) and the CEO office (59\%) (BSR Media Center 2013).

The corporate sustainability professionals frequently collaborated with the NGOs (76\%), industry associations (75\%) and other companies (70\%). Only $46 \%$ of the corporate sustainability professionals collaborated with the government and $27 \%$ collaborated with the media (BSR Media Centre 2013). The World Business Council for Sustainable Development (WBCSD) was formed in 1995 with the goals of capacity building, promoting transparency and information sharing and managing change towards sustainable development. In 2009, Vision 2050 was created wherein WBCSD highlights its goal of "setting a pathway towards a world in which everyone can live well considering the resources available in the planet"(WBCSD 2000).

Action 2020 was developed in order to scale the efforts of business to deliver on social, economic and environmental commitments. Action 2020 includes three components - societal / planetary goal to be accomplished by 2020 in order to achieve Vision 2050. It has identified nine programme areas. These are: business decision-making, climate, energy, external disclosure, food and land use, investor decision-making, social impact, sustainable cities, sustainable development goals, sustainable lifestyles, transforming mobility and water (WBCSD 2019). The business solutions are the impact scalable and measurable to achieve one or more societal goals by 2020. Environmental sustainability has an influence on the quality of habitat, biodiversity and thus affects living conditions of human beings.

The Global Reporting Initiative (GRI) introduced a standard guideline, the 'G4 Sustainability Reporting Guidelines'. This guideline enables sustainability reporting by organizations. The GRI along with Prince of Wales' Accounting for Sustainability project (A4S) and the International Federation of Accountants (IFAC) founded the International Integrated Reporting Council (IIRC) in 2010 with the purpose of 
developing an integrated reporting (GRI 2012). According to the Boston College Centre for Corporate Citizenship, the corporate citizenship value proposition is the implicit promise a company makes to the society to minimize harm, maximize benefits, build accountability and responsiveness, support and drive financial results.

\subsection{Researcher's experience in CS/CSR as a part of marketing strategy}

A few decades ago, CS \& CSR were considered to be a formality for most organizations in India. CSR used to be a dormant function then, and did not contribute much to the social welfare or development of the society. The effort created by environmentalists, scientific community and social organizations during the early 2000 has resulted in awareness on CSR among the members of the society. The competition among companies in the market place has also played an important role in spreading concepts on CS and CSR. The managers of organizations felt that the best way to create differentiation is to talk about the value offerings of the company. Thus CS and CSR became a part of strategic brand marketing.

During the 1990s, several multinational pharmaceutical companies in India implemented CSR as a part of marketing strategy. These were organized through 'medical camps' aimed at creating goodwill for the company among the members of the medical profession and the patients. At the end of the programme, the company representative presented corporate film of the company to promote publicity/ corporate identity through displaying banners and posters on the company with the intention of business gain. For example, during the late 1980s and early 1990s, Pfizer India undertook 'mass deworming programmes' aimed at promoting health to school children as a part of 'Combantrin marketing campaign'. In the 'Combantrin marketing campaign', the Pfizer representatives identified schools to promote its anthelmintic brand 'Combantrin'. This was organized with the support of medical professionals and the company sales team. 'Combantrin' was promoted as an anthelmintic that eradicates the most prevalent intestinal parasites. The company Pfizer provided 
adequate samples free of cost to the school children, alongwith literatures on the efficacy \& safety of 'Combantrin' together with explaining the benefits of periodic deworming.

During the late 1980s, Pfizer undertook a large scale deworming campaign across India, involving school children and published reports on the efficacy and safety of 'Combantrin' on school children. The response to 'Combantrin mass deworming campaign across India' was a major gain for Pfizer. The competitor SmithKline and French, also known as Eskayef, was compelled to initiate similar campaigns for its anthelmintic brand Zentel. In the Indian pharmaceuticals industry, the success of one company has always been duplicated by competitors from the industry. As a result, similar marketing strategies directed at the end user were initiated by brand managers across the industry. Although pharmaceutical marketers primarily targeted their marketing efforts at the medical professionals, during the 1990s, the intense competition paved way for marketing campaigns targeted at the end users- patients and customers.

Other examples of marketing strategies undertaken by Pfizer were 'Dolonex patient care programmes' to promote anti-arthritic product Dolonex (also called Feldene in the International market) to the chronic osteoarthritis, rheumatoid arthritis and patients suffering from acute musculoskeletal disorders by influencing them through the medical profession. As the competition intensifies, the managers adopt strategies and different methods of winning customers by creating a 'distinct position' in the minds of customers who are influencers and end users.

Incidentally, in the pharmaceutical marketing, companies that undertake long term marketing campaigns target the end user, with a focus mainly in the chronic therapy segments. This is because the companies found chronic therapy patient potential and profitable in the long term. For example, the multinational pharmaceutical company Astra-IDL (Astra Zeneca) undertook several marketing campaigns for its antihypertensive 
brand 'Plendil', targeted at the elderly hypertensive patients. The 'Plendil in Elderly Patients' or the 'PEP' campaign of Astra was an intense campaign focused on promoting Plendil (brand of Felodipine, a calcium channel blocker). The pharmaceutical marketing manager paid keen attention to chronic therapy segments since the patients suffering from chronic diseases consumed the medication for a life time. As a result, cardiovascular therapy segment contributed significant and sustained revenue to the companies. Similar is the case with psychiatric therapy drugs.

Socially responsible brands did exist during the 1990s. For example, 'Diabinese,' the brand of Chlorpropamide in the Pfizer's diabetic therapy basket did not generate profit for the company. So were the brands Betacortyl (Betamethasone) and Deltacortyl (Prednisolone) for immunosuppressed patients; Isonex, the brand of Isoniacid for the treatment of tuberculosis; Marax, the brand containing combinations of Ephedrine, Hydroxyzine and Theophylline for the treatment of asthma. The above brands were made available to patients with the aim of meeting demands from 'existing users' who continue to consume the medication over prolonged periods. These brands did not generate profits for the company during the 1980s and 1990s (could be mainly due to the Drug Prices \& Control Order which restricted price ceiling on essential and life saving pharmaceutical formulations under the Essential Commodities Act 1955 by the Government of India). Pfizer India continued manufacturing these brands despite low sales and called them 'service brands' since these brands served the needs of the society.

Social service initiatives by pharmaceutical companies were predominantly undertaken at the local level at the discretion of Medical Representatives who contributed samples of medicines to the poor and the needy patients through medical professionals. Large amounts of medicines were mobilized as free service to be used in medical camps and for the poor patients from rural areas. The samples donation for camps helped the Medical Representatives build relationship with doctors and thus contributed to incremental business from the territory. The pharmaceutical companies, particularly in the chronic therapy segments, supported 
doctors to a great extent through medico-marketing efforts, relationship marketing and personalized services from the field managers. The marketing communication shifted from benefit offering to value offering.

As competition intensified, the companies started expanding the target group from influencers to the end users and to the social groups. By influencing the doctors, retailers, patients and the social groups, the companies believed that they could create a significant impact and sustain their position in the market place. This enables "marketers to enter into the CSR brand wagon and brand their products and services linking with CSR programmes" (Krish 2010). Adam Lindgreen suggested that 'CSR practices are prevalent in organizations that employ relationship marketing practices' (Lindgreen et al. 2009). CSR practices helps in building networks, connections with various stakeholder groups, and win over their support and loyalty. CSR is an important arsenal in the tool of a marketer since it delivers an 'enhanced value' for the companies.

A survey was conducted in India in 2001 by the market research organization ORGMARG for TERI-Europe to understand the 'perceptions and expectations of the society towards CSR efforts'. The results of this survey highlight as follows: a majority of the respondents felt that companies should be held fully responsible for the roles for which they have direct control. These include providing good products at cheaper prices, ensuring that the company operates using environment friendly methods and policies, and good human resources practices, policy of non-discrimination towards gender, race and religion, and implementing labour standards globally. Moreover, general public felt that the companies should involve in solving issues, reduce the disparity between the rich and the poor, appreciate human rights and bring about economic stability. 
A company's CSR initiatives influence the attitude and intention in making a buying decision. Individuals who were aware of the CSR initiatives had more positive company-related associations, displayed a sense of association, identity and indicated an intention to purchase products, seek employment, and invest in the company than the respondents who were unaware of the CSR initiatives. Therefore, CSR activity has the potential to increase not only associations, attitudes, and identification but also the intent of stakeholders in committing personal resources (e.g.: labour, methods, etc.) for the benefit of the company. A key implication is to reap the positive benefits of CSR; the companies are required to put in efforts at 'raising awareness levels' (Sen, Bhattacharya \& Korschun 2006). The responses of consumers towards CSR reveal their attitude towards the company's CSR policies and their ability to accurately identify the CSR activities of the firms are quite low.

'The awareness of CSR initiative is related to internal behavioural outcomes in terms of beliefs, attitude, and identification of the customer to the concept' (Bhattacharya \& Sen 2003). Venu Srinivasan (2007) highlighted that corporate social responsibility is 'more than philanthropy' and does not refer to 'giving and receiving' (Srinivasan 2007). An effective CSR initiative engages the less privileged in a partnership with the company.

Although a large number of development measures were undertaken by the government, experience shows that these efforts often do not reach the needy and deserving ones. Industries have expertise in human resources management, financial management and business planning. Involving the corporate sector in implementing the efforts of the government establish the missing link in the public demand and supply distribution system. The companies possess leadership, managerial skill and are able to deliver resources efficiently in order to establish the 'missing link' and reach the services to deserving people. Industry must act as a catalyst for social development. They must work with the government in providing leadership, training 
and skill development through establishing skill development centers, vocational and educational institutions.

Angshuman Paul (2007) pointed out that 'CSR does not promote brand equity and its effects are not visible in the profit \& loss statement of a company'. CSR plays a role in overall corporate objectives, and as a result, a better society contributes to better quality of life.

There is a rise in public demand for socially responsible behavior by industry and social action programmes help create a favourable public image. It is in the long run interest of the company to get directly involved in social issues where the industry has necessary resources and talent pool to engage in social action programmes. In 2002, Confederation of Indian Industry, along with UNDP, British Council and PricewaterhouseCoopers (PwC) organized a survey in order to ascertain the views on CSR in India and the role that companies define for themselves in the society. The results show that 'desire to be a good corporate citizen' and 'brand value' were considered to be the two main areas of CSR that the companies aim for.

Ilan Alon and colleagues examined the intensity of corporate social responsibility communications of 105 companies with respect to motives, processes and stakeholders in Brazil, Russia, India, and China (BRIC) nations. Ilan Alon identified that 'economic factors alone are not adequate to explain the CSR behavior' (Alon et al. 2010). Although China has a higher per capita GDP, it is least communicative on CSR initiatives whereas India with a low per capita GDP, communicates the CSR initiatives better. Ilan Alon highlighted the importance of rule based governance and relation based governance, citing this example. 'In a rule based society, companies are accountable to the public, with high trust and transparency with independent courts whereas the relation based societies are less transparent, with less trust on law and public information' (Alon et al. 2010). 
The role of business in society has undergone significant changes. The business has begun to realize the need for contribution to the society and the environment. The companies are under constant audit by the regulatory authorities. According to Cannon, 'the purpose of business is to sustain its activities, maintain competitiveness and contribute to the community it serves. This is achieved by meeting the demands and producing surplus goods in sufficient amounts, creating jobs and employing people, doing innovative methods of management to generate wealth (Cannon 1994). It is expected from companies not only employ people, generate profits and pay taxes but also to be a responsible corporate citizen and also be accountable to the society' (Brown 2001). 'Business cannot be isolated from the society and society cannot exist without business' (Davis \& Frederick 1985). Thus, there is a two-way relationship between the business and the society.

\subsection{CS and CSR practices in the Indian corporate sector}

Leading corporate houses in India launched CSR initiatives since the 1990s. These companies include the Birla group, the Tata group, Balmer-Lawrie, Bharti enterprises, Bharat Heavy Electricals Limited, Bharat Petroleum Corporation, Coal India, Gas Authority of India, Hindustan Petroleum Corporation, Infosys, ITC, Indian Oil Corporation, National Thermal Power Corporation, Oil and Natural Gas Commission, Steel Authority of India and a few other several organizations. India has been recognized among the Asian countries for its importance towards corporate social responsibility disclosure norms. Tata group, an India-based multinational enterprise with a history of 140-years of commitment to the community, pioneered the CSR activities among the corporate in India. The Tata group topped the economic value creation despite the economic crisis of 2008-2009. In the year 2008-2009, the Tata group had grossed US\$70.8 billion in revenues. $64.7 \%$ of the Tata group's revenues were now coming from foreign countries. 'It is an example of value-creation, leadership, ethics and sustainable development on the backdrop of rapid 
internationalization and shifting stakeholders' expectations for corporate social responsibility' (Branzei 2010).

In 2009, the government of India made it mandatory for all public sector oil companies to spend $2 \%$ of their net profits on corporate social responsibility. The government of India has established 'Institute of Corporate Affairs' under Ministry of Corporate Affairs in order to implement programmes and policies, undertake research in the area of CSR. Today, CSR in India has grown from charity and donations to become a part of the corporate strategy. Companies have CSR teams that devise specific policies, strategies and goals for their CSR programmes and set aside budgets to support them. For example, public sector enterprises like Oil and Natural Gas Commission, Bharat Petroleum Corporation Limited, Steel Authority of India Limited, Balmer-Lawrie adopt villages with a focus on developing them. They provide education infrastructure, medical and sanitation facilities and houses. This helps villagers to become self-reliant through training on vocational and business skills. The corporate possess expertise, strategic thinking, resources and financial capabilities to facilitate social development. 'Effective partnerships between corporate, the NGOs and the government will place India's social development on a faster track' (Sathish, Ramya 2010). The corporate has demonstrated their ability to make a significant stride in the society by improving the quality of life of the people.

\subsubsection{CS \& CSR practices of multinational companies}

\subsubsection{Amway}

Amway is a direct sales organizations operating in more than 80 countries. It consists of over 3 million independent business owners (IBOs) and is a family-owned business with focus on family values. The company holds relationship ties with children. The families associated with the company are happy to partner with Amway. Amway works with the UNICEF in undertaking immunization campaign and projects supporting children. As a family company, Amway is committed to playing a part in 
improving the lives of children in need across the globe. In this way, the company is able to commit to a cause through corporate social responsibility. Amway defines CSR as a global cause and 'a social issue affecting many people around the world engaged in a struggle or plight that warrants a charitable response' (Charantimath 2011). Amway's vision is to help people lead better lives. It helps its distributors by selling quality products. This is an example of low-cost low-risk business.

\subsubsection{Bharat Forge}

A billion-dollar worth Indian multinational company based in Pune district of Maharashtra State, has transformed itself from a supplier of automotive components to a preferred engineering, design and technology company. The company Bharat Forge positions itself in the five high growth verticals- oil and gas, construction and mining equipment, railways, marine engines and components, and aerospace. The sustainability statement of Bharat Forge is stated as follows: "As a technology-driven manufacturing company, we are extremely focused on people capabilities and are working towards creating a 'global talent pool'. It has been our endeavor to create more brain power in our company by bringing education into our system and by providing opportunities for higher learning" (Bharat Forge 2013).

In order to realize its ambitions, the company Bharat Forge has tied up with leading institutions such as Birla Institute of Technology and Sciences (BITS) Pilani for Bachelor's in Manufacturing Engineering, Warwick University in UK for Masters in Engineering and Business Management; and Indian Institute of Technology Mumbai. As its CSR initiative, Bharat Forge supports 150,000 children through its PPEF (Pratham Pune Education Foundation). The primary goal of PPEF is to impart primary education, bridge courses and outreach programmes to the underprivileged children in the age group 3 to 14 years. The company Bharat Forge set up Industrial Training Institute (ITI) in 2007 at Khed, in Pune to impart technical training to the rural youth. Bharat Forge ITI was recommended by KRDWG (Knowledge Resource Development 
and Welfare Group) expert panel for Educational Excellence Award 2012. The company set up three more of it is in the state of Maharashtra.

In the field of sports, Bharat Forge identifies and nurtures talented tennis players helping their training abroad and participation in events by supporting them through 'Lakshya' (Looking at knowledge in sports and help youth achieve). 'The CSR activities organized by the employees of Bharat Forge are in the areas of environment, adopting schools and old age homes around Pune wherein each department of the company adopts an institution as a part of the CSR programme (Bharat Forge 2013).

\subsubsection{Canon}

Canon originated in Japan in 1933 with the establishment of Precision Optical Instrument Laboratory for research on cameras. The company is focussed mainly in the optical instruments and has produced 'serenar' lens and Japan's first indirect Xray camera. During the 1940s, Canon achieved several accolades for innovations in imaging technology (Canon 2013).

The corporate philosophy of Canon is based on 'kyosei'. 'Kyosei refers to the belief that all people, regardless of custom, language, religion, race or color harmoniously live and work together towards a common future. Canon feels that the current economic factors, limited resources and environment make it difficult to realize 'kyosei' (Canon 2013). Canon attempts every effort to overcome these limitations and propagate 'kyosei' through corporate initiatives. According to the philosophy of Canon, true global companies must develop good relationship with customers, communities, government, region and environment to achieve 'kyosei'. The goal of Canon is to achieve prosperity and wellbeing of humanity across the globe with an effort to achieving 'kyosei' (Canon 2013).

The guiding principle of Canon is based on the ' 3 selfs' which are 'self-motivation', 'self-awareness' and 'self-management' (Canon 2016). 'Self-motivation refers to 
taking initiative and being proactive in every activity. Self-awareness refers to conducting with accountability and responsibility. Self-awareness refers to understanding one's situation and role' (Canon 2013).

\subsubsection{Coca-Cola}

Coca-Cola India strived hard towards water conservation and community development and has been awarded 'The Golden Peacock Global Award 2008' for contribution towards CSR. The award has been conferred for its efforts in water conservation and management and community development initiatives. The soft drink major now has 320 rainwater harvesting implements across 17 states in India, and it has also been successful in implementing water conservation programme. The company is also promoting the 'elixir of life' project that provides drinking water to about 30,000 children in 100 primary and panchayat schools in around Chennai. Coca-Cola undertakes several initiatives across India under the CSR banner wherein the company implements a range of activities for the social development and conservation (Kaul 2007).

\subsubsection{Crompton Greaves India}

Crompton Greaves (CG) has incorporated CSR council involving all business heads in order to create new initiatives and review progress of various projects by the units. The CSR statement defines the activities to be implemented in the business, workplace, community and environment. The CSR programmes of Crompton Greaves India include the academia-industry interface, affirmative action, community services, environment, fundraising and combating HIV/AIDS. The affirmative action refers to sustainable development through teamwork and includes promoting social equality and supporting marginalized communities.

Crompton Greaves together with Confederation of Indian Industries (CII) signed CGCll Code of Conduct in November 2006 to provide social justice to the outstanding 
students among the scheduled caste and scheduled tribe by means of educational sponsorship, book sponsorship for mentoring outstanding girl students. Crompton Greaves is organizing CG-CII finishing school projects, prepares students for entrance examination for professional courses, provides education to physically challenged and deprived categories of students, delivering vocational programmes and working with universities.

During the period 2007-2009, Crompton Greaves India collaborated with seven educational institutions in five locations (Ahmednagar, Nashik, Bhopal, Indore and Goa) supporting 567 scheduled caste / scheduled tribe students. During the academic year 2008-2009, Crompton Greaves extended tuition fee scholarships to meritorious students with scheduled caste / scheduled tribe background, who are the top three rank holders in the field of electrical, mechanical, electronic, and metallurgical branches from all sixteen National Institute of Technology (NITs). Crompton Greaves collaborated with a local organization 'Chetna' for the community development of the Kanjur and Gurari villages where the majority of the 'bottom of the pyramid' population lives. These villages are adjacent to the CG facilities. CG employees contributed 3055 man days for the CSR programmes during the period 2007 to 2009.

\subsubsection{DHL India}

The CSR motto of DHL India is called 'living responsibility'. The focus areas are environmental protection (GoGreen), disaster management (GoHelp), education (GoTech) and support employee volunteerism (Go Volunteer). The CSR strategy of $\mathrm{DHL}$ is central to the corporate mission of the company. Being a logistics service provider, the company is committed to a strong social commitment, connecting people and making their lives easier through its service. The shared value of DHL is environmental protection (GoGreen), and the corporate citizenship programmes are GoTeach and GoHelp. Caring the environment is vital for the DHL because the shared value proposition GoGreen enables the $\mathrm{DHL}$ organization to be an eco-friendly 
company. Innovative solutions enable DHL to enhance productivity and reduce dependence on fossil fuel and thus reduce cost.

\subsubsection{DuPont India}

The sustainability journey of DuPont has evolved over the last few decades. Sustainability is the core focus of DuPont's business strategies. The focus of DuPont is in the area of food security, agriculture, nutrition, advanced materials and bio-based industrials. The company has achieved its sustainability goals of 2012 well ahead of the close of the financial year. In the 2020 sustainability goals, DuPont has set a target on food security and energy. The core values of the company are in the areas of health and safety, environmental stewardship, ethical behavior and respect for people.

\subsubsection{Ford India Private Limited}

Ford India has a modern plant at Chennai and 304 sales and service network across 164 locations in India. Ford employs 11,500 people in India and expects to add another 5,000 people to its new state-of-the-art integrated manufacturing facility. The corporate philosophy of Ford is termed 'Better World' with a focus on improving the quality of life and empowering future generations. 'Operation Better World' addresses issues related to education, sustainability, auto safety and community welfare. The sustainable policy of Ford stated in the Policy Letter 17, dated August 28,1996 , highlights that Ford is committed to meeting regulatory requirements that apply to its business such as protecting health and environment based on the following principles: 'Protection of health and environment is an important consideration in the business decision. The products, services, processes and facilities are planned and operated to incorporate objectives and targets which are periodically reviewed in order to enhance the efficiency of operations, minimize waste, reduce pollution and minimize any adverse impact on health and environment'. 
At Ford India, 'protection of health and environment is a company-wide responsibility. Management of each activity is expected to accept this responsibility as an important priority and to commit the necessary resources. Employees at all levels are expected to carry out this responsibility within the context of their particular assignments and to cooperate in Company assignment' (Ford India 2014). As a recognition to its contribution to the society as a responsible corporate citizen, and for adopting high standards of corporate governance, Ford India has been nominated for 'the US Secretary of State Award for Corporate Excellence 2005' (Ford India 2014).

Ford India undertakes efforts towards positive engagement in the community. According to a report published in the Ford India web page in the year 2006, the company has been able to bring about a reduction in power consumption to an extent of $35 \%$. During the past four years, Ford India made efforts to reduce fuel consumption. The diesel consumption per car was reduced by $18 \%$ and water consumption per car was reduced by $25 \%$ (Ford India 2014). "The company has been able to reduce the volatile organic compound (VOC) emissions from $115 \mathrm{~g} / \mathrm{sqm}$ area of car body painted in the 2003 to $59.1 \mathrm{gm} / \mathrm{sqm}$ in the year 2006. The qualities of air at the facilities were monitored through an ambient air quality monitoring and stack emission monitoring. The company initiated various measures for the reduction in greenhouse gas emission. Ford India management used Energy Utility Waste Metrics (EUWM) to track corporate citizenship efforts and supports metrics for the Safety Quality Delivery Cost Morale (SQDCM) scorecard" (Ford India 2014).

Ford India undertakes annual environment compliance assurance audits in the beginning of every year by the internal audit team. The assessment includes environmental legal compliance to be adhered such as air and water pollution, hazardous waste disposal, etc. Ford India is ISO14001 compliant. The CSR initiatives undertaken by Ford India are in the areas of community welfare, education, healthcare, environment and safety. The CSR initiatives include establishment of the 
Sanjeevi Health Centre, The Henry Ford Chair for Vehicle Emission Research and The Henry Ford Chair for Biomechanics and Transportation Safety at Indian Institute of Technology at Chennai and New Delhi respectively. Ford India also supports the 'Automobile Research Association of India'. As a part of the community initiative, Ford India collaborated with Confederation of Indian Industry (CII) in providing livelihood, community infrastructure and capacity building of tsunami affected victims of 2004.

\subsubsection{GE India Limited}

GE India is a diversified company in the areas of healthcare, energy, innovation, locomotives and diesel engines for railways, fuel-efficient jet engines and financial services. GE has been operational in India since 1902 and employs 15,000 people across 13 manufacturing and services locations in India.

GE Volunteers is a community service organization involving 3,500 retired members of GE across seven major cities in India. The goal of GE Volunteer is to improve community and lives through leadership, volunteerism and comradeship. GE Volunteers in India, during the past five years, have contributed over 125,000 volunteer hours in partnership with non-profit and government-run organizations. GE Volunteers have been associated with NASSCOM foundation, police department, National Association of Blind, several major eye hospitals in the city of Hyderabad, Rotary International, Jet Airways and several other organizations. GE Volunteers were involved in planting trees in over 300 acres of land during the last three years. GE Volunteers in India is a testimony of 'good people doing great things'.

GE Foundation is a philanthropic foundation of GE that invests in improving access to quality education as well as strengthening the community. GE Foundation scholarships are awarded to science, engineering and management students with leadership potential. GE provides GE Star awards to eligible children and wards of GE employees and retirees. GE runs scholarship at Cummins College of Engineering for 
Women, where it sponsors the education of five students annually. GE's Global Research Centre in Bangalore, John F Welch Technology Centre (JFWTC) offers Early Identification Programme (EIP) wherein undergraduates and graduate engineers work on real-time technology challenges, gain hands-on experience and share workspace with inventors and scientists. Close to 100 leadership programmes is available to GE employees in India. GE reimburses $85 \%$ of tuition costs and has welldefined flexibility policies to help employees balance their deliverables at work while pursuing their education. GE offers Crotonville Leadership courses to help accelerate leadership development of its employees. The company has also initiated 'RESTART' programme for women scientists and engineers who wish to return to work after a career break.

Through its 'healthymagination' strategy, GE India is focused on developing technologies for in the therapeutic segments of cardiology, oncology, maternal healthcare, hospital management systems and improving health care processes for lowering healthcare cost while enhancing quality and access to healthcare. Through its 'ecomagination' strategy GE India is committed to developing innovative solutions and services to address environmental challenges. The innovative solutions are gas engines with high efficiency, renewable energy solution based on biomass and wind turbines for low wind regions in the rural areas.

The company also developed Value CT, a scan designed for smaller cities in India. GE India has developed 'Lullaby LED, an efficient phototherapy system for neonatal jaundice. The phototherapy lamp using LED technology breaks down bilirubin $28 \%$ faster than conventional phototherapy and lasts 50 times longer and consumes less power than CFL. GE Technology Centre in Bangalore, during the last 12 years has contributed to filing more than 1850 patents for the parent General Electric Company. 


\subsubsection{Glaxo SmithKline Beecham Pharmaceuticals}

The CSR programme of Glaxo SmithKline primarily focuses on health and healthy living. The company works in tribal and rural areas of the country in making medicines accessible to the people. The company undertakes health camps and health awareness programmes. The company works with not-for-profit organizations towards delivering the healthcare services to the communities that are under served. The company organizes free health camps in rural areas.

\subsubsection{Hindustan Unilever}

Hindustan Unilever, the subsidiary of Unilever Group is involved in a number of CSR initiatives in India. The main objective of project 'Shakti' of Unilever is creating rural entrepreneurs. Hindustan Unilever has trained 13,000 underprivileged Indian women to distribute the company's products in the rural areas, enabling the company to have access to additional 70 million rural consumers. The company engages in women's self-help groups with the objectives of training them on selling skills, imparting knowledge on basic accounting and commerce. These programmes help the participants improve their living. Thus the participants, by and large, are able to double their household income.

According to an article published in the Business Line newspaper, "Project Shakti has also extended the market penetration of Unilever. Unilever has been able to increase its reach to $30 \%$ more of India's rural population since its inception in 2000 . The company is supported by about 300 groups, NGOs, banks and various government organizations enabling it to take part in strategic public-private partnerships" (Vackayil 2007).

\subsubsection{IBM India}

IBM has set up IBM School of enterprise wide computing at the educational institutions in India. At 'Indian Institute of Information Technology' (IIIT), IBM offers 
short term courses to the public. IBM also offers courses to the students and graduates to enable them obtain 'credit' for the courses they have undertaken at IBM. IBM also set up a research laboratory at the Indian Institute of Technology (IIT) in New Delhi. IBM invested $\$ 100$ million in India for the development of software labs.

The CSR activity of IBM is called CSCs (Corporate Service Corps) and employees of IBM (IBMers) publish their activities towards the society in the website www.desicorps.com. IBM works in partnership with several non-governmental organizations. In the Alwar district of Rajasthan, IBM implemented IBM Kidsmart early learning programme in 12 government primary schools during the year 2011. This has benefitted 2,000 students. IBM works through STEM Foundation (an NGO) teaching children during the weekends through innovative robotics training platforms.

\subsubsection{Indian Hotels Company Limited}

The Indian Hotels Company Limited (IHCL) is a global hospitality property chain and a part of the Taj group; include the Taj hotels, resorts and palaces with over 75 properties in 60 locations. The IHCL is committed to social responsibility since its inception in 1903. The company is committed to serving local communities by furthering education and skill training, particularly among the rural population, preserving art and culture, promoting sustainability. The company initiated EARTH (Environment awareness and renewal at Taj Hotels) strategy in order to initiate environmental management, sustainable tourism in the business operations. The IHCL has received environmental certification for travel and tourism from EarthCheck, an agency for environmental certification of travel and tourism. 


\subsubsection{Intel India}

Intel has created value for stakeholders and reduced costs through energy conservation, minimized risk by working proactively with the communities and supply chain, building trusted relationships worldwide. Intel is a member of UN Global Compact and has published Intel human rights principles re-dedicating its commitment to CSR. At Intel India, the CSR is about innovation and meeting challenges in the area of education, environment and healthcare.

The Intel code of conduct serves as a cornerstone of Intel culture, directing the employees and the managers to consider long term and short term impact on environment and community in business decisions. Intel India, through its open and direct communication, rewards and recognizes its employees for performance. Intel India's investment in employees through career development and leadership makes Intel a 'great place to work'. Intel India maintains sustainability in its operations by designing facilities that conserve water and energy. Intel India has conferred two national awards for excellence in energy management. Between 2005 and 2009, the annual sales volumes of Intel CPUs (computer processing units) sold in India increased by $42 \%$, whereas their aggregate annual energy consumption reduced by 82\% (Intel India 2010).

Making use of harvested rainwater for cooling tower helped Intel India save an additional 14 million liters of rainwater per annum. This eliminates municipal water use equivalent to water consumption of approximately 100 households in Bangalore every year. Intel India executed 15 energy conservation projects with a saving of 750,000 kwh (kilowatt hour) of electricity. The above examples are efforts of energy efficiency measures adopted by Intel India in its energy conservation efforts.

The 'Intel Teach' programme helps teachers integrate technology and 'real-life' active learning into the classroom. Intel Foundation has extended learning beyond the classroom to more than 100,000 young people. Every year Intel organizes "Initiative 
for Research and Innovation in Science" (IRIS) jointly coordinated by Intel India, Department of Science and Technology (DST) and Confederation of Indian Industry (CII) to identify brilliant young minds, which is the single largest science initiative in India. The Intel higher education programmes in India supports university faculty and students to advance research and education in mathematics, science and engineering and collaborates to create technology entrepreneurship programmes. This programme has reached out to more than 20,000 students and 1,500 faculties in leading scientific and technological institutions across India. Through research grants, technology entrepreneurship forums and mentoring, Intel helps reach technology from the laboratory to the community. The winners of India Innovation Pioneers Challenge (IIPC) developed innovative solutions to solve various social issues in the areas of healthcare technology and rehabilitation of spastic children.

Intel India collaborated with several organizations, including UNESCO to advocate for educational excellence and access. Intel India expanded its efforts to the underprivileged and remote areas of north eastern states of India. Intel together with a nongovernmental organization Amba, developed a distinct training methodology to offer training to the intellectually challenged thus providing livelihood to the differently abled community. Intel supported this programme through offering hardware technology, certification and funds, and spread the initiative to 22 centers across India training and rehabilitating $\mathbf{4 5 0}$ members of this marginalized society. Intel India launched rehabilitation programme aimed at small and marginalized farmers, women through market linked micro enterprises. This scheme has helped more than 4,000 people in the Bagalkot district of Karnataka state (Intel India 2010).

\subsubsection{Microsoft India}

Microsoft India addresses the needs of semi-urban, rural, non-English speaking people in the country. Apart from the funds that it has provided, to the tune of more than $\$ 1.15$ million in the country, Microsoft is continuously introducing software to 
address the needs of the society. Recently, as part of its effort at bringing an affordable local language computing solution for India the company launched Windows XP starter edition exclusively developed for India (Raman 2006).

\subsubsection{Mitsubishi Heavy Industries}

Mitsubishi Heavy Industries (MHI) formulated its group supply chain CSR guidelines based on five points which are:

(i) Compliance and corporate ethics,

(ii) Safety, cost, quality and innovation,

(iii) Human rights, health and safety,

(iv) Respect for the environment, and

(v) Contribution to the region and the society.

$\mathrm{MHI}$ believes that the basis of CSR is 'to engage is business activities that take into consideration the interests of diverse stakeholders, optimally return profits to them, provide excellent technology and products to realize a sustainable society and secure future for people and planet' (MHI Global 2015). The corporate identity statement of MHI is "our technologies, your tomorrow". MHI has been a participant of UN Global Compact since 2004 and supports "the 'ten principles' in the areas of human rights, labour, environment and anti-corruption" (UN Global Compact 2016). MHI complies with the ISO26000 guidelines for its CSR activities (MHI Global 2015). In India, MHI set up India scientific laboratory support project in collaboration with Plan Japan, a Japanese NGO during the period March 2013 to February 2014 with a focus on improving quality of education and training next generation technicians in India. As a part of its environmental vision 2021, MHI strives to create a low carbon recyclingbased society. 


\subsubsection{Motorola India}

Motorola believes in creating innovative products and solutions with a focus on exceeding customer expectations. The corporate responsibility business principle at Motorola is about value of doing the right thing at all times. Motorola operates with a high level of ethics, transparency and foster sustainable use of resources in products and operations. Motorola creates and engages a workforce that can contribute its full potential and an inclusive work environment. Motorola cooperates with its employees in maintaining a safe and healthy workplace and support employees' 'work-life balance'.

In addition, Motorola works to create wealth, economic opportunity and growth in business through products, operations and relationships. Motorola ensures that its suppliers comply with the laws and accepted standards of human decency and fairness. Motorola supports community, environment, and education needs of the community where it operates and strives to achieve strong financial results through sustainable planning. In India, the CSR activities of Motorola India initiated 'technology barrier reduction programme' wherein Motorola focused on mitigating the issue of rural student dropout. The employees of Motorola India served as volunteers for this programme. This enabled rural students to uplift themselves in their capacity of education.

The EFY Times reported on October 24, 2011, that Motorola Mobility Inc. volunteered over 200 employees in India during the first global community service programme organized by the company. Other community projects initiated by Motorola India are its efforts to keep the Bangalore Doddenkuundi lake green by cleaning the weeds in the lake, leveling the area and planting saplings. Motorola employees across India spread the 'green knowledge' amongst children. The employees were also involved in 'greening' an old age home by way of gardening, removing weeds, lawn mowing and watering plants. Motorola India also cooperated 
with volunteer organizations like Concern India Foundation, Literacy India, Little Sisters of the Poor and Restless Development in order to build awareness on social issues, health and environment (EFY Times 2011).

\subsubsection{Nestle India}

Nestle India is the market leader in almost all the segments and enjoys a high market standing and brand value. The CSR philosophy of Nestle incorporates compliance, sustainability and creating shareholder value. In the district of Moga in Punjab, Nestle India created dairy farming by providing farmers with technology producing milk hygienically with reduced wastages. Nestle believes in creating shared value by helping communities (CNBC News 2010).

Due to the sustained efforts of Nestle India, the farmers in Moga village own a larger numbers of cows, earning money by selling milk to Nestle, which empowers them to get credit from banks in order to invest in property extensions. In addition to this, acquiring know-how on soil irrigation and improved farming techniques, the farmers became literate with over $70 \%$ literacy rates (Census 2011). The encouraging success of community development in Moga helped Nestle replicate the success in several other regions across India and also in countries such as Brazil, Thailand and China (Porter \& Kramer 2006, 11).

\subsubsection{Nokia India}

The goal of Nokia is to manufacture and deliver sustainable mobile products and devices that incorporate best environmental and social practices and enable people to improve their lives. Nokia's firm commitment to sustainability is reflected when it laid-off 10,000 workers. Nokia did not say goodbye just like the other organizations did. Instead, it created a 'bridge programme' aimed at supporting the employees who were laid off, thus creating new businesses. 
According to United Nations Environment Programme, approximately 50 million tonnes of electronic waste is generated every year. Nokia accepts all types of mobile phones which are sent to recyclers and recycled. Nokia has more than 6,000 collection points across 100 countries for the voluntary take-back programme for the old mobile devices. Nokia set up a small bio-fuel station at its Chennai facility in India. Nokia works closely with its suppliers and logistics service providers to reduce the environmental impact of its devices. Nokia expects its suppliers to comply with ISO14001. Nokia Asha 200 and 201 are the first eco-hero devices available at the low price segment.

Nokia sustainability leadership team develops the group-wide sustainability framework containing strategy, targets and priorities. Nokia's sustainable related policies and management systems include the following: Nokia code of conduct, Nokia global employment guidelines, Nokia labour conditions standard, occupational health and safety policy, environmental policy, Nokia supplier requirements, Nokia policy against illegal trade of natural resources, Nokia human rights approach, Nokia privacy policy, environmental management systems, and risk and opportunity management process (Nokia Sustainability Report 2011).

\subsubsection{Procter \& Gamble India}

Procter \& Gamble (P\&G) India has a presence in home care segment, beauty \& grooming segment, and health \& wellness segment. Technological innovation and value added products enabled the company to achieve the market leadership position in the respective segments. Sustainability is integrated into the core values of P\&G touching and improving lives of millions of consumers for generations to come. P\&G commits itself to this responsibility through environmental sustainability and social sustainability. To fulfill its environmental sustainability vision, P\&G focuses on

(i) Powering the plants using renewable energy. 
(ii) Using $100 \%$ recycled or renewable material for all products and packaging.

(iii) Ensure that the zero consumers' and manufacturing waste go to landfills, and

(iv) Designing products that delight consumers while maximizing company's efforts on conserving resources.

As a part of its social responsibility, P\&G India focuses on helping India through 'Live, Learn and Thrive' campaign with a purpose of access to education and skill development. Under its social initiatives 'Siksha' and 'Parivartan-Whisper school programme', P\&G India has improved the lives of over 315 million children from the lesser privileged background through providing access to education and health.

The P\&G India plants in Baddi, Himachal Pradesh have achieved a reduction in carbon footprint by $40 \%$ during the last three years. P\&G India's 'Parivarthan' programme enabled girls to embrace womanhood in a positive way by adopting the right hygiene practices. The company also helped the society in the disaster relief during flood and tsunami. The Gillette plant at Bhiwandi has saved 500 gigajoules of energy during the period 2009-2011, which is equivalent to the energy required to serve the needs of more than 12,000 people in India. In order to make sustainable decisions, P\&G undertakes life cycle assessment of its products to determine the entire environmental footprint of the product from procurement to disposal.

As a part of its environmental sustainability initiatives in India, the company finds ways to deliver sustainable improvement without asking consumers to make tradeoffs in performance or value. Some of these examples are: 'Ariel Antibac' and 'Tide Plus' compact detergents introduced in India using less raw materials and packaging materials while ensuring superior consumer value. The company has redesigned the packaging of 'Whisper Ultraclean' and 'Pampers' to reduce thickness, thus resulting in a reduction of raw material usage and saving of paper. The redesigned pump 
packaging of 'Olay' reduces plastic consumption and makes it $25 \%$ lighter. This has saved the company over 400 tonnes of packaging per year (P\&G India 2014).

\subsubsection{SAP India}

SAP has focus in the areas of education, developing talent, creating technology and entrepreneurship. SAP offers the youth with skills in order to tackle problems of the society in the digital economy. SAP partners with NGO for contributing to the development of the community. SAP employees undertake voluntary work to meet the needs of the poor. "The SAP Labs Center of HOPE in Bangalore is a home for street children, establish by SAP in collaboration with a nongovernmental organization HOPE. This home provides basic necessities, education and shelter to the street children" (Sathish, Ramya 2010).

\subsubsection{Siemens Limited}

Siemens Limited is the market leader with business activities in areas of energy, healthcare, heavy engineering, automation and locomotives. In Siemens, corporate citizenship is an integral part of overall sustainability strategy. Siemens Business Conduct Guidelines (BCG) is an instrument for all internal stakeholders in promoting ethical, transparent, accountable behavior. Siemens have developed code of conduct for channel partners with the aim of promoting ethical and sustainable practices along the supply chain.

Siemens India has collaborated with several partners- AROEHAN, local government authorities, Smile Foundation (Delhi), Medicity Hospital, Welfare society for destitute children, Oxfam India and ACTION Aid. In addition, the employees of Siemens undertake Siemens volunteering programme for community development. During the year 2011, the company spent INR6.4 million $(\$ 128,000.00)$ towards social development projects. Siemens India spent $0.3 \%$ of its net profit as a contribution towards CSR. Through its project Asha, Siemens India helped the villagers manage 
and maintain the water purification system and solar power station. The Sanjeevan mobile clinics improved the public health delivery system in the rural areas. The company also organized drought relief activities in the Jalna district of Maharashtra with a focus on training villagers in the rural areas on the public distribution system and watershed management programme (Siemens India 2013).

\subsubsection{SKF Bearings Limited}

SKF India has received the Dun and Bradstreet Rolta Corporate Award for the year 2012, consecutively for six years for being the 'top Indian company' in the bearings sector. SKF is dedicated to sustainable development through business care, environmental care, employee care, and community care. SKF has technology expertise in the manufacture of systems such as seals, bearings and units, mechatronics, lubrication systems and their services. The focus of SKF is aimed at minimizing damages to the environment caused by its products during its life cycle (both at the manufacturing stages and utilization stages). An example is an effort of SKF towards 'BeyondZero' product portfolio reducing the environmental impact from its business.

Business Care: The essence of business care at SKF is offering better products and solutions to customers, which in turn help improve their operational or product performances. SKF believes in ensuring responsibility and accountability in its business practices. SKF aligns its business operations and strategies with its values and principles as well as environmental challenges facing the company. The business care responsibility includes responsible sourcing, business ethics and anticounterfeiting.

Environmental care: Environmental care includes environmental life cycle management, the businesses and core processes. SKF adopted sustainability reporting guideline in 2001 in line with the GRI requirements. SKF life cycle management aims at optimizing equipment design and operations over its entire 
service life cycle. SKF India complies with ISO14001 Environmental Management Systems, ISO50001 Energy Management Systems.

Through its SKF 'BeyondZero' strategy, SKF India has been able to reduce the energy requirements for manufacturing operations by $14 \%$, the $\mathrm{CO}_{2}$ greenhouse gas emission level by $16 \%$ between 2006 and 2012 while the business grew by over $20 \%$ during this period. The facilities of SKF at Ahmedabad, Pune and Mysore are certified LEED (Leadership in Energy and Environmental Design) by the US Green Building Council (USGBC).

Employee care: Employee care includes respecting and protecting the rights of employees, offering safe and good working conditions through its 'Code of Conduct'. SKF undertakes group-wide employee survey every year, called 'Working Climate Analysis' (WCA). The survey is related to feedback company performance by the employees related to values, key focus areas, sustainability, knowledge sharing and business operations. This helps the managers and their teams to develop plans for improvement.

Community care: SKF India together with Pimpri Chinchwad Municipal Corporation (PMPC) and NAVAM, an NGO set up SKF sports academy for the underprivileged in Pune in 2005, with the objective of providing children with physical and mental growth and development through sports activities. The SKF sports academy provides football, cricket and hockey coaching sessions to both boys and girls. The senior management in SKF India volunteered to mentor programme to children through career planning, health and social issues.

Adjacent to the SKF facility at Pune, 'The Udyogdham' leprosy centre was established in 1975 to rehabilitate the afflicted patients and their children. Donations in terms of office stationary, providing bicycles, desks, electrical wiring at the institute were provided by SKF, thus integrating these children into the society. SKF India along with 
Samrathanam trust, an NGO enhanced the individual abilities of less fortunate people through project 'Tech-Vision' in Bangalore (SKF India 2014).

\subsubsection{Tata Group}

Tata group comprises of over one hundred companies, has presence in seven core business sectors- chemicals, consumer products, engineering, energy, information technology, materials and services. Tata group, during 2012-2013, reported a revenue of $\$ 96.79$ billion of which $62.70 \%$ of this business comes from outside India. The Tata Council for Community Initiatives (TCCI) assists the Tata companies and employees to engage in the community development and assists in the community reporting as per the guidelines set by GRI. 42 Tata companies are signatories to the UN Global Compact. Tata Index for Sustainable Development was crafted by the Tata group in collaboration with United Nations Development Programme (India). The aim of this initiative is to influence the lives of common people by making improvements through the business processes.

The Tata Index for Sustainable Development comprises of processes and outcomes at three levels namely: Level 1- System response, Level 2- People response, and Level 3Programme response. There are 17 sub levels and 46 parameters under each level, cumulating to a score of 1000-point value. In the Tata Index for Sustainable Human Development, a point of $0-250$ is categorized as human consideration, value points $251-450$ is categorized under human concern. The point value range $451-650$ is categorized as human achievement wherein companies and people collectively accomplish goals. The point value 651-875 range is categorized as human development wherein the realization that community building is the core to human survival and growth. Point value $876-1000$ is categorized as human excellence

At $\mathrm{TCCl}$, the important belief is that the purpose of business is to enhance the wellbeing of all stakeholders. The stakeholders gradually become long-term owners of the enterprise through assuming leadership and co-creating sustainable values for 
the society and themselves. Tata believes that building a community of stakeholders on "relationships with trust" is important to promote inclusive and sustainable growth.

Co-creating sustainable value has been practiced in the Tata group for several years through stakeholder engagement. Tata group endorses the view that business should be profitable and the companies are leaders in the segments they compete.

However, the financial goals are 'means to multiple aspirations or non-financial goals of businesses. "The sustainable value creation generates lasting benefits, considers future needs and ultimately serves a larger purpose. It is about building collective and multiple forms of capital - human capital, social/cultural capital, natural capital, economic capital and financial capital" (Tata Services Limited 2012).

Human capital refers to the development of employees, healthy people, educated population, active volunteering, youth and leadership, artisan and entrepreneurship development. Social capital refers to stakeholder accountability, enhancing capacity on corporate sustainability, building community and networks, creating institutions, rehabilitation and resettlement in new projects, and encouraging supply chain at the base of the pyramid. Natural capital includes environment conservation, restoration of biodiversity, wildlife protection, management of the scarce resource, and greening the supply chain. Economic capital includes employment generation, price stabilization, improving employability, and regional development. Financial capital includes livelihood generation, income enhancement, and enhancing shareholder value.

Tata Affirmative Action Programme (TAAP), implemented in 2007, is focused on four areas of development such as employment, employability, entrepreneurship and education to address social inequalities prevailing in India and to encourage positive discrimination of scheduled caste /scheduled tribe communities (SC/ST). The 24 of Tata group companies, through the AA (Affirmative Action) policy, have spent close 
to INR70 million ( $\$ 1.156$ million) on more than 13,000 scholarships for students from marginalized communities.

In addition, in partnership with Foundation for Academic Access and Excellence, the 25 of Tata group companies have spent INR7 million $(\$ 115,626)$ per annum on more than 140 scholarships to meritorious poor students enrolled in professional colleges. 34 Tata companies were involved in skill development programmes benefitting more than 16,000 youth among the SC/ST community during 2011-2012. Several of the Tata companies provided development programmes to encourage vendorentrepreneurs from the marginalized communities. The value of business outsources to vendors under Tata Affirmative Action Programme has grown from INR400 million (\$8 million) in 2010-11 to INR900 million (\$18 million) in 2011-12. The Tata group has made considerable progress towards estimating carbon footprint of 50 largest of the Tata companies and attempting to bring down carbon emission by $10 \%$ to $15 \%$ without influencing the business. The company is evolving knowledge on climate science through involvement in sustainability projects and exploring technical solutions for a low carbon economy.

\subsubsection{CS \& CSR practices of Indian private companies}

\subsubsection{1 $\quad$ ACC Limited}

ACC Limited is India's leading manufacturer of cement and concrete. It has 17 manufacturing facilities, more than 40 ready mix concrete employing more than 9,000 people and a distribution network of 9,000 outlets throughout the country. ACC began its operation in 1936 and is the forerunner of implementing environmental policies. ACC installed pollution control equipment long before pollution control laws came into force in India. ACC has been able to reduce its carbon footprints by $32 \%$ since 1990 and this will further reduce by $20 \%$ by 2040 . ACC uses industrial, municipal and agricultural waste for its manufacturing operations thus contributing to sustainability. 
The CSR initiatives of ACC began as early as 1944 with activities largely classified as philanthropy. Since 1952, ACC has incorporated community development initiatives to the needs of its areas around its operations in order to add greater value. ACC has created Community Advisory Panel (CAP) as a platform to implement projects in coordination with the community, district administration, NGOs and other opinion groups. During the year 2013, the community development initiatives were focused on 132 villages with a population of 0.6 million located around the 17 plants of the company.

The CSR expenditure of ACC during the financial year 2013 was INR227.6 million (\$3.759 million) which is $1.94 \%$ of the PAT average (ACC News 2013). ACC revisited its CSR policies and constituted CSR committee and focused on community development, enhancing literacy, education, health, sanitation, livelihood, employability, income generation, women empowerment and augmentation of the community infrastructure. The Community Advisory Panel conducted baseline studies, need assessment surveys before initiating a development programme. Stakeholder engagement survey (SES) was performed every year in order to obtain feedback on the progress and outcome of the projects undertaken.

The efforts of ACC benefitted 18,380 children in the neighborhood communities. ACC established schools near its facilities providing quality education to the children of employees and those from surrounding communities. ACC outsources reputed educationalists like the DAV or the best locally available institution ensuring high standards of education. ACC supported the schools with initial infrastructure construction and providing funds towards a part of teachers' salary and for upgradation. In the year 2013, ACC supported 666 meritorious students from the weaker section of the community through a grant of scholarships for continuing education. 
ACC implemented educational initiatives such as kiosks and smart classes benefitting 12,695 school children. 851 dropout girl children were provided specific educational support. Under public private partnership (PPP) scheme, ACC supported seven government-run Industrial Training Institutes (ITIS) with a focus on enhancing skills and employability. The Sumant Moolgaokar Technical Institute (SMTI) at Kymore was set up in 1957 to train technicians. ACC Cement Technology Institute (ACTI) at Jamul offers the course on operation and maintenance of cement plants. ACC initiated 'bridge schools' facilitating tuition in subjects Mathematics, Science and English to students from grade 1 to 10 in the villages of Amheta, Kharkhari, Kalhera, Amuwari and Khalwara, surrounding the plant ACC Kymore. This has resulted in high success rates with the majority of students scoring marks in the first or second division. ACC has set up 'Arogya Daan' to support the healthcare initiatives of the company.

The sustainable community development programmes have directly benefited more than 109,000 individuals through various health and nutrition-related initiatives. ACC extended support to ACC hospitals, various government primary and community health centers in the locality. ACC initiated Integrated Child Development Scheme (ICDS) called Angawadi in the rural areas for overall development of children, pregnant and lactating mothers. ACC supported 132 angawadi centers. ACC established two anti-retroviral treatment centers in the states of Karnataka and Tamil Nadu for the treatment of HIV/AIDS. ACC established ACC Ayushman Trust in Karnataka and ACC CMC Trust for infectious diseases in Vellore, Tamil Nadu in association with Christian Medical College.

\subsubsection{Aditya Birla Group}

Aditya Birla group is a $\$ 40$ billion Indian conglomerate employing 120,000 people belonging to 40 different nationalities. The Aditya Birla group is ranked No. 4 among the top companies for leaders' survey and ranked No. 1 in Asia Pacific for 2011, according to Aon Hewitt, Fortune Magazine and RBL, a strategic HR and leadership 
advisory firm. About $50 \%$ of the company's revenue flows from its overseas operations in 36 countries. Hindalco-Novelis is a flagship company of the Aditya Birla group, manufacturing cost efficient aluminium and copper products. Hindalco is one of the three largest producers of aluminium in Asia. Grasim is the No.1 producer of viscose staple fibre and Birla Carbon is the largest producer of carbon black.

The Birla corporate social responsibility was initiated in the Aditya Birla group company in 1940 by its founder Shri GD Birla through trusteeship management concept wherein the wealth is held in a trust by multiple stakeholders. Mr Aditya Birla extended this concept from trusteeship to sustainable livelihood. Aditya Birla group reaches out to 7 million people across 3,000 villages through Aditya Birla centre for community initiatives and rural development with a focus on livelihood, education, social reforms, infrastructure and sustainability. The Aditya Birla group runs 42 schools in India aimed at providing quality education to 45,000 children of which 18,000 belong to the underprivileged. In addition, 8500 children from the rural areas receive merit scholarships from the company. The Aditya Birla group runs 18 hospitals in the rural areas.

The Aditya Birla group spends in excess of INR1,300 million ( $\$ 21.473$ million) towards developmental efforts. Aditya Birla group supports Habitat Humanity India through donor-ship and thus helped them build over 3,000 houses for the homeless. However, the requirement is over 50 million houses of which 25 million in the urban areas in India. The efforts of Habitat India are to mobilize resources in building 1 million homes for the homeless by 2015 (Aditya Birla Management Corporation 2014).

\subsubsection{Ashok Leyland}

Ashok Leyland is the 2nd largest manufacturer of commercial vehicles in India, headquartered at Chennai (Madras) having an annual revenue of US $\$ 2.3$ billion (2012-2013) with operations in more than 50 countries. Ashok Leyland is also the 4th 
largest manufacturer of buses and 16th largest manufacturer of trucks globally. Ashok Leyland has a fully integrated manufacturing facility in India catering to the needs of more than 70 million passengers with 700,000 trucks plying every day across India.

The CSR initiatives of Ashok Leyland are largely in the areas of environment, ecosensitive manufacturing systems and processes, energy conservation and green initiatives. The company attempts to develop eco-friendly engine technology with reduced emission. Ashok Leyland introduced the first CNG powered bus in India in 1997 and today it has about 6,500 CNG powered buses. Ashok Leyland developed the first hybrid electric vehicle in 2002 and CNG hybrid plug-in bus powered by CNG and electricity in 2010. The company also developed the country's first Hythane engine in 2009 , powered by hydrogen and CNG thus reducing the emission of the CNG engine.

The Ashok Leyland Driving Training Institutes at Namakkal, Tamil Nadu state and Burari near Delhi have trained more than 350,000 drivers. Several such institutes are being planned to meet the demand for trained drivers. Ashok Leyland is the first commercial vehicle manufacturer awarded with ISO14001 and the first to achieve zero water balance. The Ashok Leyland facility at Ennore, near Chennai, redeems 1.28 million liters of water from the sewage every day in an effort to conserve water. The company has planted more than 250,000 saplings and contains 162,000 meters of green grassland across various facilities.

In the year 1995, the company invested in wind farm, and today it has 240 windmills of capacities ranging from $225 \mathrm{~kW}$ to $1250 \mathrm{~kW}$ producing $63.5 \mathrm{MW}$ of energy. More than $60 \%$ of the power requirements of the facilities are met through wind energy. The company also has set up a separate company Ashok Leyland Wind Energy Limited to harness the wind energy business. The Ashok Leyland corporate office has been awarded the LEED certification by the India Green Building Council (Ashok Leyland 2014). 
The company also undertakes community services by way of donating buses to schools, providing desks and benches, free meals, charity services and relief operations during a disaster. As a part of its driver engagement programme, the company, in association with TVS dealer has instituted "All The Best" scholarship scheme for the children of drivers in 2010. Ashok Leyland, in association with the Department of International Development and the British High Commission, organized the Truckers Interim Coordination Unit (TICU) focused on HIV/AIDS awareness.

\subsubsection{Bharti Airtel Limited}

Bharti Airtel Limited is a leading mobile service provider in India ranked number 4 globally on the customer base, with operations in 20 countries, catering to 465,482 towns and villages with 188.22 million mobile subscribers in India and 71.62 mobile subscribers internationally. Bharti Foundation focuses on realizing the vision of Bharti Airtel in social responsibility. Bharti Foundation, through its initiative Satya-Bharti programme, helps children and young people of India realize their potential. There are 254 Satya Bharti schools with 39,535 students enrolled in the programme. The objectives of Satya-Bharti school are as follows:

(i) To provide free and quality education to rural, underprivileged children, with a focus on girls.

(ii) Help students emerge as educated, confident, responsible and selfreliant employable citizens who are deeply committed to the society.

(iii) Encourage active involvement with the community, parents and likeminded community.

(iv) Making lasting and sustainable impact on the community, where schools are present. 
(v) Find innovative solutions through its primary, elementary and senior secondary schools to create replicate and scalable components in the programme to impart quality education.

In collaboration with an NGO 'lamGurgaon', the Bharti Airtel employees planted 2,000 saplings in the Gurgaon Biodiversity Park. In Rajasthan, the Airtel employees along with local NGO 'Paaniram' planted 2500 saplings. The employees of Airtel organized disaster relief, distributing food and clothes to the affected persons in the Assam valley. The company also regularly organized blood donation camps across various regions in India. Airtel also launched various SMS campaigns to drive social welfare and drive awareness (Bharti Airtel Annual Report 2013).

\subsubsection{Coromandel International}

Coromandel International competes in the plant nutrition solutions segment and is India's second largest manufacturer of phosphate fertilizers. The company has a presence in the following areas - fertilizers, specialty nutrients, crop protection and retail. The annual turnover of Coromandel International during the financial year 2013-14 is INR93,810 million (\$1.549 billion). Coromandel International was ranked among the best twenty companies to work for (Business Today) and voted as one of the best ten green companies in India (The Murugappa Group 2014).

The CSR initiative of Coromandel International towards community development is construction of St Ann's Jubilee Memorial super specialty hospital adjacent to its facility at Visakhapatnam. This hospital caters to the underprivileged section of the society. In addition, the company donated medical equipment for diagnosis. Other areas of CSR are donation towards flood relief, education of rural girl child, organizing medical camps and environment clean-up activities. Launched in the year 2005, the rural girl child education initiative helped more than 4,300 rural girls back to school. In the year 1975, the company instituted gold medal for the 'best outgoing chemical engineering student' from Andhra University, Vishakhapatnam. 


\subsubsection{Dr Reddy's Laboratories}

Dr Reddy's Laboratory is Indian pharmaceutical company with global operations, committed to providing affordable and innovative medication to patients. The corporate values of Dr Reddy's Laboratories are integrity and transparency, safety, quality, productivity, sustainability, respect for individual, collaboration and teamwork. Dr Reddy's is the first Indian pharmaceutical company to be registered under the GRI and reports sustainability as per the GRI guidelines. Dr Reddy's Laboratories was awarded 'Asia Best CSR Practices for 2013' by CMO Asia and World CSR Day. The company has not published its 2012-13 sustainability reports due to multiple fatalities in its manufacturing operations between October 2010 and September 2011 (Two fire accidents involving death of three workers as reported in 'The Hindu Business Line' dated March 19, 2011).

The company has identified eight other pillars of sustainable operations which are people, quality, availability, environment, community, engineering excellence, productivity and continuous Improvement. Some of the key initiatives of the company include 'quality by design', 'self-managed teams', applying the concept of 'theory of constraints' and focus on 'programme to achieve cost and capabilities excellence.'

As a part of its environmental management strategy, Dr Reddy's implemented initiatives green chemistry, solvent recovery, waste reduction at source, water and energy audits, water harvesting and recycling. Dr Reddy's chemical manufacturing facility at Nalgonda, Andhra Pradesh state meets $30 \%$ of its requirements through the recycled water. During $2011-12,7 \%$ of the energy requirements were met using renewable resources (coal is being replaced with agricultural waste briquettes for boilers at its Hyderabad plant). The company is attempting to recreate a process of energy efficiency. Dr Reddy's corporate office at Hyderabad is a certified LEED building. 
Dr Reddy's Foundation (DRF) is a non-profit arm of the company for executing its social projects- supporting education, employee volunteering, organizing health camps, disaster relief and infrastructure development. Key healthcare focus of the company is in the areas of cancer care -awareness campaigns, preliminary screening and providing subsidized mammography.

DRF initiated Livelihood Advancement Business School (LABS) for skill development of youth through 112 LABS across 21 states in India. 'Labs for Farmers' (FLABS), a programme directed towards marginalized farmers in adopting sustainable farming methods is another effort of DRF. Under the Skilling Rural India (SRI) programme, DRF has been able to provide technical training to 5,598 rural youth from the underprivileged section of the society in Andhra Pradesh during the year 2012.

DRF organized 853 'Abhilasha" training programmes directed towards enhancing efficiency and effectiveness benefitting 22,058 nurses. In addition, DRF organized 238 'sarathi' training programmes benefiting 6,083 physicians. Both these training programmes for the medical professionals were organized in collaboration with Osmania University.

During the financial year ending March 2011, the company reported a total of 254 incidents of which 18 resulted in 20 Lost Time Injuries (LTIS) including 6 fatalities. During the financial year ending March 2012, the company reported 397 incidents of which 14 resulted in Lost Time Injuries (LTIS) including 3 fatalities. In partnership with DuPont safety management, Dr Reddy's embarked upon project 'parivarthan' towards a safety culture transformation during the month August 2011 (Dr Reddy's 2012).

\subsubsection{Godrej Industries Limited (GIL)}

Godrej Industries (formerly Godrej Soaps Limited) is a leading manufacturer of industrial chemicals used in the manufacture of cosmetics, tyres, pharmaceuticals, 
consumer products, etc. GIL is a part of $\$ 1.87$ billion Godrej group, establish in 1897. The strategic CSR initiatives of Godrej are to work towards a 'Good \& Green' goal and maintain the position as one of the most socially and environmentally responsible companies in India. The Good and Green goals of Godrej for 2020 are:

- Organize training programmes to 1 million urban and rural youth in skill and enhance their earning potential.

Achieve zero waste to landfill, carbon neutrality, a positive water balance, $30 \%$ reduction in specific energy consumption, increase utilization of renewable energy consumption through 'green India' projects.

- The revenue generated from the portfolio should contain one-third good/green products that are environment-friendly and addresses critical social issues for the consumers at the bottom of the income pyramid (Godrej Industries 2014).

\subsubsection{Hero Motor Corp Limited}

Hero Motors Corp Limited is the world's largest two-wheeler manufacturer, a flagship company of $\$ 3.2$ billion Hero group started in Ludhiana, Punjab in 1947 with the objective of providing the basic transport (bicycles) to the common man. Three decades later, as the nation evolved, the company started manufacturing mopeds catering to the needs of the middle-class Indians. During the 1980s, the company collaborated with Honda Motors to produce high fuel efficient $100 \mathrm{cc}$ four stroke engine Hero Honda motorcycles. The Hero Motor Corp has set up several educational institutions in Ludhiana. The Dayanand Medical College \& Hospital at Ludhiana, one of the best and not-for-profit medical colleges in India is run by Hero Motor group. The Raman Kant Munjal Foundation is the philanthropic organization set up by the founder Shri Brij Mohan Munjal, which runs a higher secondary school and a modern equipped 100-bedded hospital at Dharuhera, near the facility of Hero Motors. The 
Hero Motor Corp has adopted several villages and provided basic amenities such as roads, street lights, drinking water and sewerages (Hero Motor Corp 2014).

The vision of Hero Motor Corp is in sustainable development- balancing the nature, business and mankind. The company has adopted "green initiatives" and is the most environment-friendly company in India. Hero Motor Corp plans to adopt green initiatives along its supply chain and operations as well. The company has invested in 'clean processes' to reduce the impact on the environment by obtaining 'green quotations' for the inputs and raw materials that go into the processes. To reduce carbon footprint, the company has eliminated harmful substances such as asbestos, hexavalent chromium and phenolic substances.

The Hero Motor Corp has adopted 'green roof' in an area of 45,000 sq.km, an effort to conserve energy by moderating the temperature on the roof, and the surrounding areas. The company has also adopted treating and recycling of water used in the cooling towers and efficient effluent treatment. Through its organic waste converter, the company has been able to dispose-off the municipal waste hygienically. The company recycles 150 tonnes of paint sludge and additives annually and converts them to paint primer. The solvent recovery machine prevents $59 \mathrm{kl}$ of volatile organic compounds from getting released into the atmosphere annually.

The energy conservation projects initiated by Hero Motor Corp are heat recovery from incineration. During 2011, these projects helped the company save 1,258 tonnes of $\mathrm{CO}_{2}$ emission and 1,622,400 units of energy. The $100 \mathrm{~kW}$ solar power project helped the company save 156,000 units of energy annually, 121 tonnes of $\mathrm{CO}_{2}$ emission and 36.96 tonnes of furnace oil. In order to further reduce $\mathrm{CO}_{2}$ emission, the company replaced the 400-tonne air conditioner with a VAM chiller which produces chilled water through heat generated from power generator sources.

The company has been able to recover 56 liters of oil per day per plant through the installation of chip wringer. In addition, the online hydraulic filtration system has 
saved 1,200 liters of oil annually. Hero Corp has undertaken a major initiative in the area of water conservation through rainwater harvesting and waste water recycling through effluent treatment plants. The catchment area in the plant measuring 260,000 sq.m has a potential recharge capacity of 132,600 cu.m (cubic meters) rainwater annually. The effluent treatment plant recycles 1,400 kld (kilolitres per day) of effluent every day using reverse osmosis and ultra-filtration techniques. Hero Motor Corp has been certified ISO14001, OHSAS18001 and ISO9001.

\subsubsection{Hindustan Construction Company Limited (HCC)}

Hindustan Construction Company $(\mathrm{HCC})$ is an engineering and construction services company, pioneer in the infrastructure sector in India. The HCC group has a presence in the infrastructure, real estate, urban development and management and is known for precision in engineering design, high return on investment, on time delivery and quality. HCC was awarded the 2014 Global Sustainability Leadership Award for 'Best Community Action for the 'Ujjivana' community development project and 2013 Award for Social Investment Strategy by World CSR Congress.

The HCC corporate stewardship is implemented through three main areas:

(i) Beyond Bread (sustainability, disaster relief, water management, community initiative and HIV/AIDS awareness).

(ii) Gulabchand Foundation (development initiatives on health and education for the underprivileged), and

(iii) Thought Leadership (skill development).

HCC has adopted GRI standards in its reports. The first, second and fourth sustainability reports of HCC were categorized as A+ by the GRI, reflecting the progress made by HCC in terms of achieving its sustainability goals of water neutrality, minimizing construction waste, community development and zero 
reportable injuries for employee health and safety. HCC is a member of GRI's Working group on construction and real estate sector supplement (HCC 2010).

$\mathrm{HCC}$ has the expertise in reinstating critical infrastructure required for managing supply chains and reconstruction of the health and educational infrastructure. HCC has undertaken disaster relief operations in the Uttarakhand flash flood (2013), Leh flash floods, Bihar flood of 2008 and Bangladesh cyclone of 2007, emergency relief in West Bengal train accident in 2011, earthquake relief in Sikkim (2011) and Jammu and Kashmir (2005). The community initiatives undertaken by HCC are in the areas of education, water, disaster management and HIV/AIDS awareness through public private partnership.

The Gulabchand Foundation was established in 2003 to carry out developmental initiatives in health and education for the underprivileged section of the society in both rural and urban areas. In the area of healthcare, the Gulabchand Foundation supported five cochlear implant surgeries in children from 2005 to 2012 at PD Hinduja hospital, Mumbai. The foundation also supported two municipal hospitals in Mumbai by donating pressure garments for post burn scar management and physiotherapy for the victims of burns from the underprivileged section of the society during 2007 and 2008.

In the drought-hit Kutchi village of Sangli district in Maharashtra, the company set up a health centre in association with Bharatiya Vidyapeeth hospital and the village authority in 2007, and supported this health centre till 2009. In association with Impact India Foundation, the company acquired a Lifeline Express, a mobile diagnostic clinic for early detection and treatment of sight and hearing impaired in the rural district of Thane, Maharashtra.

The educational initiatives undertaken by Gulabchand Foundation include providing primary education to 3,650 children during the year 2007-08 in Northern Mumbai along with Pratham, a non-governmental organization. Gulabchand Foundation 
supported eighteen special schools for mentally challenged children by appointing a speech therapist and facilitated training and integrating these children into the mainstream. The company has undertaken adoption of animals and supported People for Animals (PFA).

\subsubsection{ITC Limited}

ITC Limited occupies a dominant position among the private sector companies in India. It has a presence in FMCG, hotels, paperboards and specialty papers, packaging, agri-business and information technology. ITC has a business turnover of US\$7 billion and is regarded as one of the top ten valuable brands in India and offers direct employment to over 31,000 people. ITC is carbon positive, water positive and waste recycles positive. ITC meets $38 \%$ of its energy requirements from renewable resources. All ITC premium luxury hotels confirm to the LEEDS (Leadership in Energy and Environmental Design) standards (ITC Limited 2014). The watershed development initiatives of ITC conserve soil and moisture to 149,000 hectares of land. The soil and farm forestry initiatives of ITC has greened 163,000 hectares of land.

The sustainable policies of ITC include "life cycle sustainability, stakeholder engagement, responsible advocacy, product responsibility, responsible sourcing, freedom of association, diverse and equal opportunity, prohibition of child labor and prevention of forced labor at the workplace, human rights consideration of stakeholders beyond the workplace, and environment health and safety" (ITC Limited 2014). In the area of social responsibility, ITC has created around 6 million sustainable livelihoods, created a community asset by strengthening production base of nearly 400,000 farmers. The e-Choupal initiative of ITC is the world's largest rural digital infrastructure enabling access to cost effective quality goods for enhancing productivity and has benefitted over 4 million farmers. The women empowerment initiatives of ITC helped 40,000 women in the rural areas. The livestock initiative of 
ITC has provided animal husbandry services to over 1 million milch animals. The sustainability reports of ITC have been confirmed to GRI guidelines since the last ten years (ITC Limited 2014).

\subsubsection{JSW Group}

JSW Steel is one of India's leading integrated steel producers with a capacity of 14.3 MTPA. The company is a part of US\$11 billion conglomerate JSW Group. JSW has a presence in innovative and sustainable areas such as steel, energy, cement and infrastructure. JSW Foundation is the sustainability and corporate responsibility arm of the organization focused on community development in the areas of education, healthcare, livelihood, sports, art and culture. The aims of JSW Foundation are to undertake periodic studies and research on various marginalized groups, women, biodiversity, health and local agriculture. The objectives are to provide primary education, health, facilitate access to water and sanitation, skill development through vocational training and education. JSW collaborates with the government organization, civil society for poverty alleviation and implementation of sustainable models so as to reach the community.

The JSW Foundation, in collaboration with non-governmental organizations, has planned and developed water supply system at Vijayanagar. JSW Foundation established remedial education centers in Vasind, and an information technology project in Salem. Some of the projects of JSW are Integrated watershed management project established in association with research organizations 'International Crop Research Institute for Semi-Arid Tropic' (ICRISAT), 'Centre for Consultative Group for the International Agricultural Research' and the Government of Karnataka for undertaking feasibility of undertaking soil and moisture conservation and agriculture productivity enhancement spread over four villages covering 5,000 hectares of land (JSW 2013). In collaboration with Krishi Vigyan Kendra (KVK) at Barmer in Rajasthan State, JSW Foundation has been able to help the farmers enhance productivity of 
crops by $50 \%$ through technical collaboration in the areas of crop management, horticulture, silvi pasture, livestock management and vermin compost. This has benefitted 40 families.

The OPJ Centers at Vijayanagar and Vasind have trained 4,142 students, mostly school dropouts, in technical trades. JSW Foundation collaborated with NTTF (Nettur Technical Training Foundation) offering one year NTTF-OPJ Certificate in Plant operation and maintenance with $100 \%$ job guarantee. 2,594 students have been trained so far. JSW has set up a training centre for girls in apparel and textile. The OP Jindal study centre set up at Indira Gandhi National Open University (IGNOU) assists students from the underprivileged section in the management programme. In collaboration with the Government of Karnataka, JSW set up Rajiv Gandhi Institute for Steel Technology (RGIST) to provide Post Diploma in Industrial Safety and Diploma in Metallurgical Engineering. JSW partnered with Birla Institute of Technology \& Science (BITS) Pilani offering BS degree in process engineering.

\subsubsection{CS \& CSR practices of public sector enterprises}

\subsubsection{Balmer-Lawrie \& Company Limited}

Balmer-Lawrie is classified as Miniratna-I public sector enterprise under Ministry of Petroleum and Natural Gas. Balmer-Lawrie has a presence in industrial packaging, grease \& lubricants, performance chemicals, tours \& travels, logistics infrastructure, logistics services, refinery \& oilfield services. The company has integrated the interest of business with the society in its vision and mission statements and is attempting to align the CSR projects with the business operations of the company (Balmer-Lawrie 2013). Balmer-Lawrie Initiative for Self-Sustenance (BLISS) and Samaj Mein BalmerLawrie (SAMBAL) are directed towards long-term activities in the area of social welfare. BLISS is focused towards upliftment of the under-privileged section of the society and SAMBAL is focused towards improving the life of the community around the facilities/locations of the company. During the year 2012-13, the company spent 
in excess of $2 \%$ of the budgeted post-tax profit, amounting to INR303 lakhs $(\$ 500,496)$ towards implementing CSR (Balmer-Lawrie 2013).

The company partnered with several nongovernmental organizations in the areas of child care and sustenance, education, healthcare, sanitation, drinking water (reverse osmosis lift pump), income generation, skill building and environmental protection. In the area of education, Balmer-Lawrie provided financial support in improving the infrastructure in Dara Adarsh Vidya Mandir School in Dara village, Sundarbans, remote area of Bengal, benefitting 2,500 students from the underprivileged section of the society. The company awarded scholarships to students from the weaker section of the society for pursuing higher education. The company supported 100 children under the Community Education and Empowerment Programme (CEEP) along with Tomorrow's Foundation. These children living in the slum areas have never been to school, from the marginalized society were rehabilitated to the mainstream. Balmer-Lawrie, in association with Helpage India, supported mobile medical unit providing medical care to 12,000 patients in and around Manali, Chennai. The company also provided pre-natal and post-natal care to 220 pregnant women every week through its Child in Need Institute (CNI) clinic at Pailan, 24 Parganas in West Bengal.

The company also constructed 128 modern toilets in the Khandoli village at Silvassa. Reverse Osmosis plants for safe drinking water were set up at Aganbadi in Sayali, Silvassa. In addition, the company has commissioned 64 modern toilets, 7 tube wells and undertook the repair of tube wells in various villages in the Sundarbans district of West Bengal. The company imparted skill training to 105 girls in collaboration with IATA Training \& Development Institute and Trade Wing Institute for Management. The company also offered financial support to the local Industrial Training Institutes at Silvassa. 
In the area of child sustenance, the company sponsored three family homes comprising of 30 destitute orphan children of SOS Children's Village. The company also sponsored two classes for 28 physically challenged students at the Indian Institute of Cerebral Palsy (IICP), Kolkata towards rehabilitation. The company sponsored 25 differently gifted children belonging to the Backward Community at the 'Institute for Backward and Handicapped People' at Bahala, West Bengal. The company encouraged art and culture by promoting 'Swaryatra' along with Sundarban Rural Development Training Centre through a revival of classical poetry. In addition, Balmer-Lawrie sponsored mid-day meals to school children, carried out computer training courses and livelihood projects in the rural areas.

\subsubsection{Bharat Heavy Electricals Limited}

Bharat Heavy Electricals Limited (BHEL) is a maharatna public sector enterprise. "BHEL is engaged in the design, engineering, manufacture, construction, testing, commissioning and servicing of a wide range of products, systems and services for the core sectors of the economy, and is categorized as the largest engineering and manufacturing company (BHEL 2013). BHEL is a leader in the power sector in India with $72 \%$ market share and employs 48,399 people (BHEL 2013).

To address the growing demand for energy, the company has established the capacity to deliver 20,000MW energy annually. The company has high-quality standards and reliability adopting world class technology from leaders in the industry. The manufacturing facilities of BHEL match with that of the international standards with ISO certifications: Quality Management Systems (ISO9001:2008), Environmental Management Systems (ISO14001:2004) and Occupational Health and Safety Management Systems (OHSAS18001:2007; BHEL 2013).

The mission statement of BHEL is 'delivering sustainable business solutions to the country in the fields of energy, industry and infrastructure' (BHEL 2013). BHEL follows guidelines on CSR and sustainability issued by Department of Public 
Enterprises (DPE). The three CSR committees are sub-committee, level I committee and board level committee for social responsibility and sustainable development (BLC for CSR \& SD). According to Government of India DPE guidelines for sustainable development in 2011, the Board of Directors (BoD) mandated that the committee will also oversee the sustainable development activities. BLC consists of two functional directors and at least one independent director. BoD decides the reconstitution or change in BLC.

Level I Committee includes head of HSE and CSR (chairperson), head of corporate finance- member, in-charge corporate communication- member, in-charge corporate HR -member, in-charge corporate HSE \& CSR (member) and in-charge (HSE) member. The sub-committee on CSR \& SD includes the committee constituted by the level I committee to assist in the evaluation of CSR \& SD proposals. The level I committee consists of corporate HSE \& CSR, corporate communication and corporate finance. The above three committees are responsible for undertaking to screen, reviewing, recommendation and approval of CSR \& SD projects undertaken by BHEL (BHEL 2013).

The sustainable development projects undertaken by BHEL are water management, rain water harvesting, energy management (conservation and energy efficiency projects), waste management, installation of solar photovoltaic based system (Gridconnected and standalone), installation of renewable energy based system (other than solar photovoltaic), protection, conservation and restoration of ecosystem, pollution prevention and others (capacity building, reporting, etc.).

BHEL has identified six categories of stakeholders (society, employees, shareholders, customers, suppliers and government) and prepared engagement modes and activities for the stakeholders. The method of stakeholder engagement towards the society is through CSR programmes, CSR surveys and identifying the needs of the 
society. The activities undertaken are through implementing CSR projects (BHEL 2013).

\subsubsection{Bharat Petroleum Corporation Limited}

Bharat Petroleum Corporation Limited (BPCL) is a leading public sector enterprise categorized as 'Navratna' under Ministry of Petroleum and Natural Gas, Government of India. BPCL has achieved gross revenue of INR253,268 crores (\$41.834 billion) from operations with the production of 22.55 MMT of crude oil during the year 20122013. BPCL is one of the few Indian companies listed in the Fortune 500 and Forbes 2000. BPCL has undertaken initiative in green fuel by setting up a biodiesel value chain through its joint venture company Bharat Renewable Energy Limited (BREL) which cultivates biofuel plants on wasteland to produce biodiesel. The company cultivates 8987 acres (3637 hectares) of jatropha and pongamia plants in wastelands of Uttar Pradesh. BPCL also plans to set up a $10 \mathrm{MW}$ capacity wind farm in Maharashtra state and 5MW to $10 \mathrm{MW}$ capacity solar farm in India.

The CSR efforts of BPCL are in the areas of education and water conservation. During 2012-13, in collaboration with 'Agastya International Foundation', a nongovernmental organization, BPCL initiated science education programme to 10,000 children living in near the LPG facility located at Solur in Bangalore. In partnership with an NGO 'Pratham', BPCL reached out to 25,000 children across 40 municipal schools in the low-income group in Mumbai. These children were completely unaware of computers.

The 'Read India' project implemented by BPCL reaching out to 50,000 children in Nandurbar and Sagar reached its third year. The computer assisted learning programme targeted at government schools in the low-income areas across eleven schools entered its third year. This programme was initiated at the LPG bottling plant at Uran, Raigad district in Maharashtra and is scaled up to seventy-five schools. BPCL introduced a professional development programme for primary teachers of low- 
income schools delivering pedagogical education through reputed NGOs. Other initiatives are the skill based training programme for women to earn their livelihood and project 'Boond' for rainwater harvesting in 20 villages. BPCL encourages its employees to excel in their respective areas of sports (BPCL 2013).

\subsubsection{Coal India Limited}

Coal India Limited (CIL), headquartered at Kolkata, India is the one of the single largest coal producing companies in the world. Coal India employs 336,688 people worldwide (Coal India Report 2014). Coal India is categorized as 'Maharatna' under Ministry of Coal, Government of India. Coal India operates through 82 mining areas across eight provincial states in India. Coal India has 237 underground mines, 166 opencast mines and 26 mixed mines; in all totaling 429. Coal India operates 17 coal washeries and manages 200 other establishments. Coal India is a signatory to the UN Global Compact (Coal India Report 2014) and is GRI compliant in sustainability reporting.

Coal India introduced a well-defined CSR policy in 2011-2012. The CSR policy coincides with the motto of the company 'growing with surroundings,' and aligns with the interest of the community. Although mining operation affects the community, Coal India recognizes the traditional rights and values of indigenous people and no violation involving rights of indigenous people were reported. Coal India has supported the community by laying public roads, constructing community centers, check dams for the benefit of peripheral villages near the mining sites and organizing health care programmes for villagers.

The CSR policy of Coal India is "operational within the radius of $25 \mathrm{~km}$ of the project site and areas including the headquarters" (Coal India Report 2014). The annual budget for CSR is calculated "based on $5 \%$ of the retained earnings of the previous year subject to a minimum of INR5 (\$0.0826) per tonne of coal production of the previous year' (Coal India Report 2014). During the year 2012-13, the company spent 
$2.5 \%$ of retained profit towards CSR. Coal India disbursed special cash awards to the meritorious children of its employees. Holidays homes in tourist spots in the following locations Puri, Digha, Goa, Manali, Nainital and Katra were available to the employees of Coal India and its subsidiaries at subsidized rates.

During the year 2013-2014, Coal India and its subsidiary companies have planted 1.33 million tree saplings over 526 hectares under its plantation/afforestation programme. Coal India has planted more than 81 million saplings in an area 34,317 hectares of land (Coal India Report 2014) till the financial year 2014.

Dust is a major source of air pollution in the mining operations. Dust particles from zero microns to 100 microns produced through various mining activities such as mining, drilling, blasting, loading and unloading are analyzed and pollution control measures were undertaken. Monitoring of particulate matter up to 10 microns and 100 microns are undertaken in and around the mine areas, residential and village areas respectively. The coal dust is controlled through effective water spraying system. Other pollutants SOx (oxides of sulphur) and NOx (oxides of nitrogen) are monitored regularly.

The waste water from the mines is treated by installing dewatering pumps on floats. This system permits pumping of clean and settled water. The Workshop Effluent Treatment Plants (WETPs) and Domestic Effluent Treatment Plants (DETPs) and quality of discharge monitored on a fortnight basis. 'The treated water is used for water sprinkling in coal transfer points' (Coal India Report 2014), in housekeeping and plantation areas. Coal India has constructed six rainwater harvesting projects as a part of sustainable development.

The company has deployed 'Clean Mining Technology' to reduce air pollution. Electricity is a major source of energy input in the mining industry. "CIL replaced conventional mercury /sodium vapor lamps with energy efficient LED / CFL and has installed solar PV power plants of 2.0MW and 0.25MW capacities at its locations and 
have been able to improve its energy efficiency from 0.80 points to 0.97 points. Coal India was awarded 'IPE CSR Corporate Governance Award 2012' for its outstanding achievement in CSR" (Coal India Report 2014). The CSR expenses were INR8.199 million $(\$ 135,431), 14.013$ million $(\$ 231,467)$ and 40.937 million $(\$ 676,198)$ during the years 2011-12, 2012-13 and 2013-14 respectively (Coal India Sustainability Report 2014).

\subsubsection{Gas Authority of India Limited (GAIL)}

Gas Authority of India limited (GAIL) is market leader in the gas transmission segment with $10,700 \mathrm{~km}$ of the pipeline network. GAIL built "large networks of natural gas pipelines, gas processing plants for the production of liquefied petroleum gas (LPG), other liquid hydrocarbons and gas based integrated petrochemical plant" (GAIL 2013). The company has moved up the value chain and stakes in 30 exploration and production blocks. GAIL is currently focusing in the area of renewable energy (capacity $118 \mathrm{MW}$ wind energy and 5MW solar plant) as a part of its drive towards reducing carbon footprint and creating a sustainable growth. The company has seven LPG plants with a production capacity of 1.40 million MT of LPG and other liquid hydrocarbons (propane, pentane and naphtha). GAIL has achieved net sales of INR473,330 million (\$7.818 billion) during the financial year 2012-2013 with a net profit of INR40,220 million (\$664.35 million) during the same period (GAIL 2013).

The company has adopted Integrated Management Systems approach combining ISO9000, ISO14000 and OHSAS18001 accreditations and is certified with Bureau of Energy Efficiency ratings (BEE). GAIL has installed solar water heaters for domestic use at the GAIL townships and the upcoming office at Noida, near Delhi is green certified. The company has replaced Closed Cycle Vapour Turbines (CCVT) with Solar PV cells at Radio Repeater (RR) stations along its cross country pipelines. The company has replaced the electrical exhaust ventilation system with eco-ventilators employing natural draught of air ventilation. GAIL has developed greenbelt spanning 
over 17.2 million square meters (approximately $41 \%$ of the company's total land holdings).

Project 'BehetiDhara' at Vijapur is a water conservation project converting open canal to piped supply resulting in a saving of 20 million cubic meters of water per annum. Project 'Jaldhara' is a watershed management project involving water audit, contour study and rainwater harvesting spread over 500 hectares of area in Vijapur. The company undertakes treatment of sewage water at its Pata Petrochemical Complex for reuse at the sports complex and horticulture facility. Thus GAIL recycles more than $50 \%$ of its treated wastewater. GAIL continuously monitors the quality of air at all its process areas and sites and rules out suspended particulate matter (SPM) and oxides of sulphur (SOx) in the atmosphere.

The CSR initiatives of GAIL are in the areas of education, skill development and healthcare. GAIL has committed INR920 million (\$15.197 million) during the period 2012-13 towards CSR. GAIL initiated project 'Pado aur Badho' to impart formal schooling to dropouts and rag pickers in slum areas in East Delhi, West Delhi, South Delhi, Noida and Ghaziabad through 250 non-formal education (NFE) centers. More than 8,900 children have been benefitted through this process. Under its Utkarsh programme, GAIL identified 100 students from the underprivileged section of the society in Kanpur locality to undergo specialized coaching for IIT/JEE (Joint Entrance Examination to Indian Institute of Technology and National Institute of Technology) and IIST (Indian Institute of Space Technology). 30 students out of 100 have been successful in the year 2012-13.

The GAIL IL\&FS Skill School imparted employment related skill training to the disadvantaged youths in Dediapada, Narmada district in Gujarat, Guna in Madhya Pradesh and Tandur, Ranga Reddy district in Andhra Pradesh. This programme has benefitted over 2,800 youths during the year 2012-13. GAIL collaborate with Wockhardt Foundation for providing medical outreach service to 200,000 people in 
250 villages in Pata, Auraya in Uttar Pradesh State, Vijaipur, Jhabua and Khera in Madhya Pradesh state.

Project 'Anhad gram' in Jhabua, Madhya Pradesh state focuses on creating livelihood to 25 tribal villages through sustainable agriculture development, animal rearing, usage of smokeless fuel, Women's self help groups (SHG) benefitting over 2,000 people. Project 'Garima' is aimed at empowering women- mothers and sisters of children studying in non-formal education centres (NFE) under project 'Padho aur Badhao' in slums in Delhi and National Capital Region. Under this project, more than 2,000 women were provided skill training in various arts, crafts and vocations. GAIL instituted GAIL charities and education trust in 2009 to provide financial assistance and scholarships to meritorious children (GAIL 2013).

\subsubsection{Hindustan Petroleum Corporation Limited}

Hindustan Petroleum Corporation Limited (HPCL) is a public sector enterprise under Ministry of Oil and Natural Gas, Government of India. HPCL has achieved a gross sales turnover of INR2,156,750 million (\$35.625 billion) during the year 2012-13 and ranked 260 in the Fortune 500 list. HPCL commissioned the state of the art facilities across various locations in India. Major facilities of HPCL are ISO14001 certified with air emission and waste management facilities at par with the best practices in the industry. HPCL commenced sustainability reporting on triple bottom line performance from the financial year 2011-12.

At HPCL, the CSR model is built in Creating Shared Value, which states that there exists a dependency relationship between corporate success and social welfare. The company believes that in order to compete effectively, business needs a healthy and educated workforce, sustainable resources and adept government. The effort of HPCL has been to develop and implement economic, social, environmental and sustainable strategies. HPCL has been involved in CSR activities since the last three decades with a focus on community, environment, product and workplace. 
The CSR statement of purpose of HPCL is:

- $\quad$ Service to the community

- $\quad$ Sustainable business process financially, environmentally and socially

- Utilizing expertise, core competence of the business for the benefits of the common people, especially the underprivileged

- $\quad$ Capacity development in the community

- $\quad$ Enhancing human excellence and improving the quality of life.

The landmark projects at HPCL during 2010-2011 are given below in table 16 .

Table 16: Projects undertaken by HPCL during the year 2010-2011 (Source: HPCL 2013)

\begin{tabular}{|l|l|c|}
\hline Projects & \multicolumn{1}{|c|}{ Purpose } & Beneficiaries \\
\hline Unnati & $\begin{array}{l}\text { To provide time bound computer training to } \\
\text { students in semi-urban and rural area }\end{array}$ & 18,550 \\
\hline Nanhikali & $\begin{array}{l}\text { To educate girl child from poor families and } \\
\text { encourage her talent in performing arts }\end{array}$ & 11,603 \\
\hline Muskan & $\begin{array}{l}\text { To save street children from trauma and } \\
\text { transform them into dignified individuals }\end{array}$ & \\
\hline Suraksha & $\begin{array}{l}\text { To prevent spread of HIV/AIDS through } \\
\text { awareness campaign among truckers on highway } \\
\text { and distribute condoms at highway retail outlets }\end{array}$ & \\
\hline Swavalamban & $\begin{array}{l}\text { To provide free vocational training to } \\
\text { beneficiaries of low income households }\end{array}$ & 5,600 \\
\hline Navjyot & To improve health index and welfare of children & 19,060 \\
\hline \multicolumn{1}{|c|}{ Total } & & 55,613 \\
\hline
\end{tabular}


HPCL has bagged 'The Golden Peacock Award for CSR' in 2005 and won the 'National Excellence Award for Innovative Techniques' for improving access to modern fuel among rural women. Under Project 'Green Visakha', HPCL planted 86,965 saplings in the city Visakhapatnam. The Mumbai refinery of HPCL has harvested about 74TKL of rainwater during the year 2012-13. The company has undertaken Flue Gas Desulphurization (FGD) projects for removal of sulphur in its Mumbai refinery. As a part of its renewable energy strategy, HPCL has initiated 100MW Wind Farm project to exploit the vast potential of the wind in the country. The company has incorporated a subsidiary CREDA-HPCL Biofuel Limited for cultivating Jatropha plant for the production of biodiesel in 15,600 hectares of land leased from Government of Chhattisgarh (HPCL 2013).

\subsubsection{Housing and Urban Development Corporation Limited}

Housing and Urban Development Corporation Limited (HUDCO) is a public sector enterprise under Ministry of Housing and Urban Poverty Alleviation. The company was established in 1970 with the aim of providing affordable housing to the economically weaker section of the society. The company has a gross income of INR29,232 million (\$482.85 million) during the year 2012-13. The urban population in India has witnessed growth rapid growth from 286 million in 2001 to 377 million in 2011. This accounts for $31 \%$ of the country's population. This figure is expected to reach 600 million by 2030, posing a challenge to HUDCO in terms of housing for the masses and infrastructure. According to 2011 Census of India, $17.40 \%$ of urban households live in slums. This poses a challenge to HUDCO in terms of housing the urban poor.

The HUDCO has played a significant role in implementing several schemes of the government of India. Under 'Jawaharlal Nehru Urban Renewal Mission' (JNURM), HUDCO appraised a total of 1,246 projects with a project cost of INR257,370 million (\$4.251 billion) for the construction and up-gradation of 1.02 million dwelling units 
across 875 cities/ towns in India. Rajiv Awas Yojana (RAY) was launched in 2009 for creating slum-free India wherein HUDCO appraised 21 pilot projects for the construction and up-gradation of 20,000 dwelling units across various regions The CSR and sustainable initiatives are given in table 17 as follows:

Table 17: CSR initiatives undertaken by HUDCO (Source: HUDCO 2013)

\begin{tabular}{|l|c|l|l|}
\hline Year & $\begin{array}{l}\text { No. of CSR } \\
\text { initiatives }\end{array}$ & $\begin{array}{l}\text { Budget } \\
\text { INR (US\$) in Million }\end{array}$ & $\begin{array}{l}\text { Released amount } \\
\text { INR (US\$) in Million }\end{array}$ \\
\hline $2010-2011$ & 3 & $148.60(\$ 2.455)$ & $45.00(\$ 0.74)$ \\
\hline $2011-2012$ & 23 & $110.00(\$ 1.817)$ & $14.926(\$ 0.25)$ \\
\hline $2012-2013$ & 27 & $94.50(\$ 1.56)$ & $98.25 \quad(\$ 1.62)$ \\
\hline
\end{tabular}

Construction of night shelters: HUDCO along with the local bodies, constructed night shelters in several cities in India.

Community pay-and-use toilets: With the help of Indian Institute of Technology Kanpur, HUDCO fabricated zero discharge toilet systems during the 'Kumbh mela' festival (festival of yogis and saints) at Triveni Sangham, Allahabad during January to March 2013. HUDCO also supported the construction of pay and use toilets in Rajasthan, Delhi, Tamil Nadu and Karnataka states of India.

Skill up gradation centers: HUDCO helped establish skill upgradation centers in various locations in the states of Karnataka, Andhra Pradesh, Gujarat and Orissa.

Disaster rehabilitation: HUDCO contributed INR2.5 million $(\$ 50,000)$ towards flood relief in Uttarakhand and allocated INR10 million $(\$ 200,000)$ towards rehabilitation and reconstruction work in the north eastern region Uttarakhand to assist the flood and landslide victims. HUDCO supported the Government for reconstruction of 
houses at Sikkim. HUDCO constructed 133 prefabricated houses for the victims of the earthquake.

Skill development: HUDCO in association with Construction Industry Development Council and state level agency 'Kudumbashree' implemented slum development programmes for the women living in slums.

Support to differently-abled persons: HUDCO collaborated with Artificial Limb Manufacturing Corporation and National Handicapped Financial Development Council organized camps for distribution of disability toolkits in Uttar Pradesh and Rajasthan (HUDCO 2013).

\subsubsection{National Thermal Power Corporation}

National Thermal Power Corporation (NTPC) is a public sector enterprise under the Ministry of Power. NTPC is categorized as 'Maharatna' enterprise. NTPC has generated $232.028 \mathrm{BU}$ of electricity contributing to $25.27 \%$ of power generated in India during the year 2012-13. The total installation capacity of NTPC group during the year as on March 2013 was 41,184 MW of which coal contributes to 85\% of the capacity (35279 MW). NTPC is ranked 337 in the Forbes 2012 list of world's largest companies, and 3rd largest in Asia amongst Global Electricity Utilities.

NTPC has a presence across the power value chain. Fuel management is one of its main priorities. NTPC plans to meet its $20 \%$ of coal requirements from captive mines. The current coal reserve of NTPC is about 5 billion tonnes. The overall aim of the company is to promote sustainability in the power sector. Indian power sector has been under global focus in the context of climate change and GHG emission. NTPC is setting up power projects using high efficiency and low emission units of 660MW and $800 \mathrm{MW}$. Three units of power project using 660MW employing 'clean technology' have already been set up at Sipat. NTPC Energy Technology Research Alliance (NETRA) has initiated a study on carbon-di-oxide fixation at its Faridabad plant. NTPC 
is in the process of working on solar irrigation power plant to reduce GHG emission. NTPC has set up 67 ambient air quality monitoring stations (AAQMS) for monitoring air quality. NTPC has planted 19 million saplings across India as a part of its green environment drive.

NTPC follows a philosophy of $3 R^{\prime}$ 's (reduce, reuse and recycle). All operating stations of NTPC are ISO14001 certified for Environmental Management Systems. NTPC plans to balance its energy generation with a mix of conventional and alternate sources of energy and has targeted 1,000MW of renewable energy by 2017. By 2032, NTPC plans to achieve $28 \%$ of its energy requirements (out of a total of $128,000 \mathrm{MW}$ ) from non-fossil sources (hydroelectric, nuclear and renewable).

The NTPC has undertaken various initiatives in the area of healthcare, education, infrastructure development, water supply, empowerment of women and sanitation. NTPC has set up several educational institutions with a focus on skill development and employability. During the year 2012-2013, the company spent an amount of INR790 million (\$13.049 million) towards CSR and sustainable development. NTPC has set up of bio-methanation plants to generate biogas from biodegradable waste. NTPC is the winner of Golden Peacock award for 2012 in the area of CSR (NTPC 2013). 


\subsection{Thematic analyses}

Qualitative data contain non-numeric information such as text documents, interview transcripts, notes, images, audio and video recordings, etc., that may be analyzed and interpreted. According to Dawson (2007), "qualitative data can be placed on a continuum along a scale with one end a highly qualitative reflective type analysis and at the other end a quantitative may through counting and coding" (Dawson 2007).

\begin{tabular}{lll}
\hline Highly qualitative & Combination & Almost quantitative \\
$\begin{array}{l}\text { Thematic \& } \\
\text { comparative } \\
\text { analysis }\end{array}$ & $\begin{array}{l}\text { Conversational \& } \\
\text { discourse } \\
\text { analysis }\end{array}$ & Content analysis \\
\hline $\begin{array}{l}\text { Reflective } \\
\text { Intuitive }\end{array}$ & $\begin{array}{l}\text { Combination } \\
\text { of reflective \& } \\
\text { intuitive }\end{array}$ & $\begin{array}{l}\text { Code \& count } \\
\text { Mechanical }\end{array}$
\end{tabular}

Figure 17: Qualitative data analysis continuum (Source: Dawson 2007)

Thematic analyses is a technique of identifying, analyzing and interpreting patterns of meanings in a qualitative data (Braun \& Clarke 2006). This is done by coding. Coding is a process of developing themes from the data sets collected by identifying the item of analytic interest in the data and targeting them with coding labels (Boyatzis 1998). Code is a descriptor of data set that assigns meaning (Seal et al. 2007). Coding is linking, and it helps the researcher in transforming data into an idea. This is achieved through recognizing patterns. Patterns lead to theme development which are theoretical construct supported by the data. Categories are useful in identifying the patterns. Categories are conceptual and abstract than codes (Saldana 2013). Themes are theoretical constructs that reflect similarities and differences across codes. 
Theme captures and unifies the nature or basis of experience into a meaningful whole (DeSantis \& Ugarriza 200: 362).

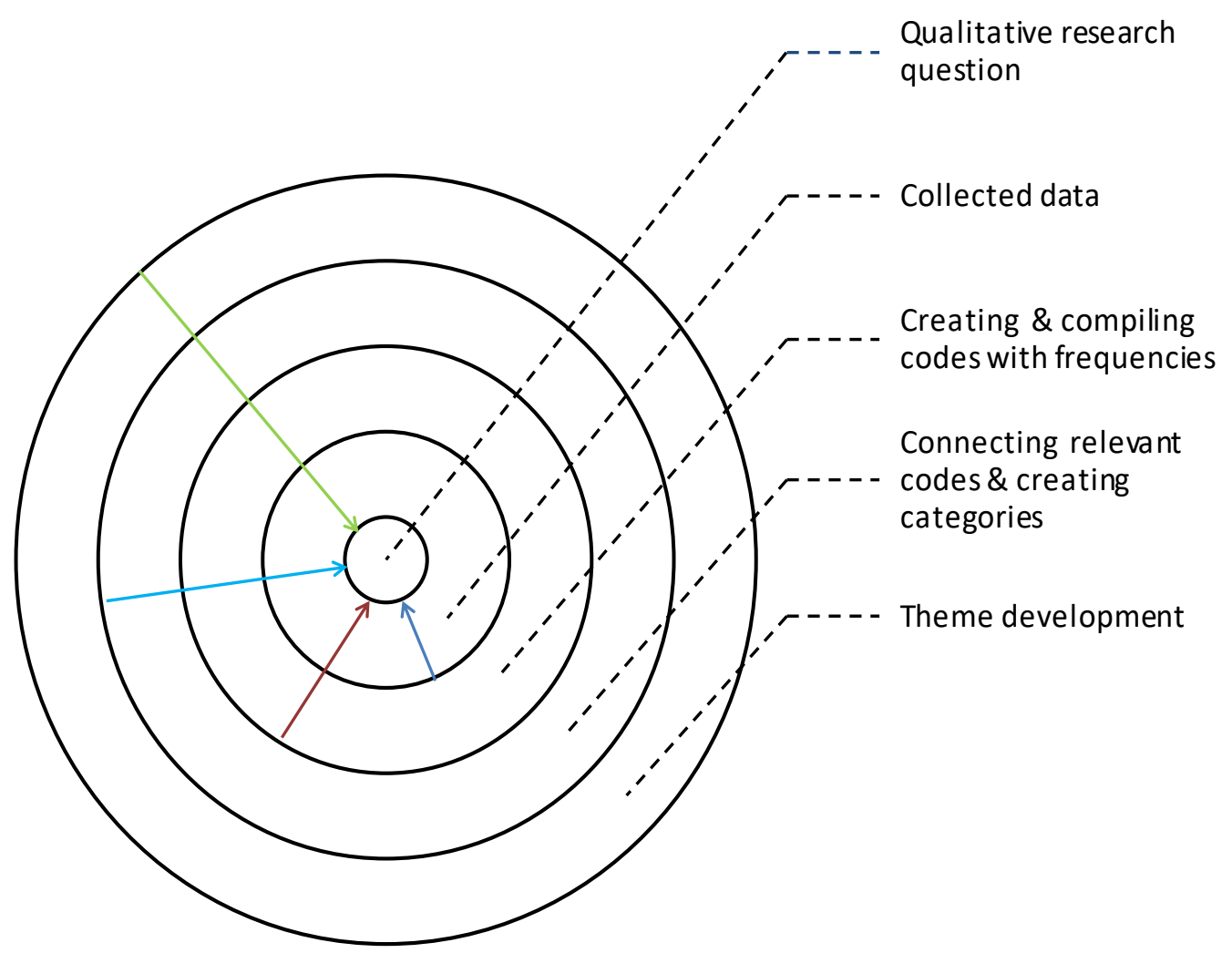

Figure 18: Theme development in qualitative research (Source: Current study)

In the current study, the researcher read and re-read several times the information collected from the three groups of companies - MNCs, Indian private and PSEs; and identified segments that are specific to the area of interest - corporate sustainainability and CSR. Codes were labeled employing the process of line by line coding. Redundant codes were identified and removed through data reduction. There were 151 codes generated from 24 MNCs, 94 codes generated from 11 Indian private companies and 92 codes generated from 8 Indian public sector enterprises selected for the study. The codes or activities representing corporate sustainability and CSR that repeated were given in the brackets as shown in the tables 18, 19 \& 20. The codes were further grouped and reduced to themes. There were 9 themes 
identified among the clusters of MNC and Indian private sector companies respectively, and 10 themes in the cluster of PSES.

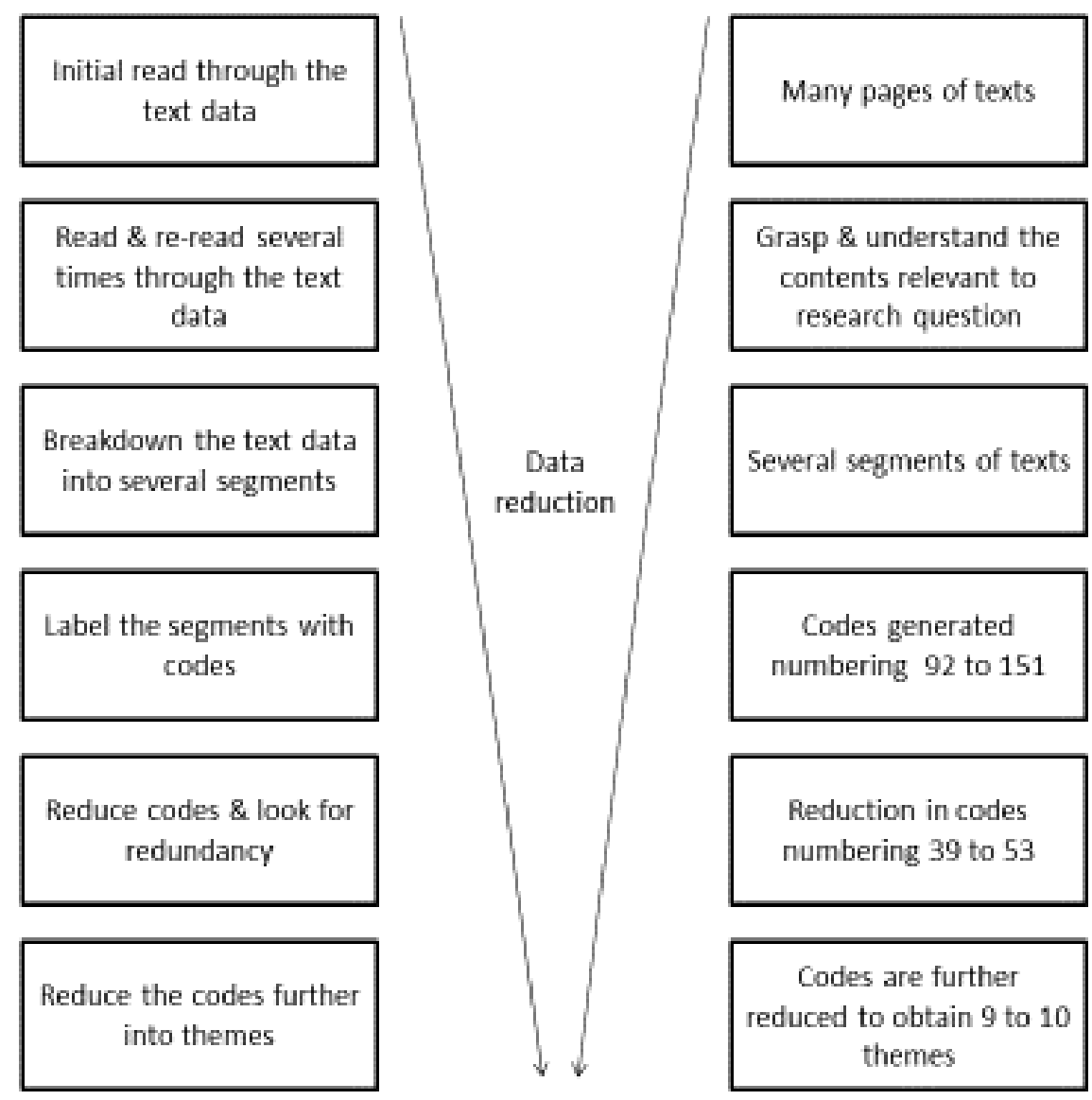

Figure 19: Generating themes through data reduction method 


\subsubsection{Thematic analysis of data from multinational companies}

The thematic analysis of Corporate sustainability and CSR initiatives of MNCs are given in table 18 below:

Table: 18 Thematic analysis of data from multinational companies

\begin{tabular}{|c|c|c|c|}
\hline $\begin{array}{l}\text { Themes derived from } \\
\text { data of MNCs }(n=24)\end{array}$ & Categories/subcategories & Frequency & $\begin{array}{l}\text { Type of } \\
\text { CS/CSR }\end{array}$ \\
\hline Social development & $\begin{array}{l}\text { community involvement (20) } \\
\text { partnership with NGOs (2) } \\
\text { rehabilitation of marginalized (2) } \\
\text { solving social issues (6) } \\
\text { supporting farmers } \\
\text { volunteering (4) }\end{array}$ & 35 & Altruistic \\
\hline $\begin{array}{l}\text { Education \& skill } \\
\text { building }\end{array}$ & $\begin{array}{l}\text { creating small entrepreneurs } \\
\text { education (10) } \\
\text { improving livelihood (4) } \\
\text { income creation (5) } \\
\text { partnership with educational } \\
\text { institutions (2) } \\
\text { skill development (10) } \\
\text { women entrepreneurship (2) }\end{array}$ & 34 & Altruistic \\
\hline $\begin{array}{l}\text { Manufacturing } \\
\text { operations }\end{array}$ & $\begin{array}{l}\text { cost reduction (2) } \\
\text { doing right at all times } \\
\text { efficiency in operations (2) } \\
\text { energy saving in operations (4) } \\
\text { exceeding customer expectations } \\
\text { leadership (3) } \\
\text { low cost products } \\
\text { market leadership } \\
\text { improved productivity (2) } \\
\text { profits } \\
\text { renewable energy use } \\
\text { sustainable use of resources (5) } \\
\text { waste reduction (2) }\end{array}$ & 26 & Strategic \\
\hline Environmental & $\begin{array}{l}\text { clean environment (8) } \\
\text { emission reduction } \\
\text { environmental auditing } \\
\text { life cycle assessment (2) } \\
\text { minimizing environmental } \\
\text { damage } \\
\text { natural capital } \\
\text { planting saplings } \\
\text { pollution control (2) }\end{array}$ & 22 & $\begin{array}{l}\text { Altruistic } \\
\& \\
\text { strategic }\end{array}$ \\
\hline
\end{tabular}




\begin{tabular}{|c|c|c|c|}
\hline & $\begin{array}{l}\text { recycling (3) } \\
\text { water conservation (2) }\end{array}$ & & \\
\hline $\begin{array}{l}\text { Stakeholder } \\
\text { engagement }\end{array}$ & $\begin{array}{l}\text { employee development (2) } \\
\text { wellbeing of all stakeholders } \\
\text { rewarding employees } \\
\text { stakeholder engagement (3) } \\
\text { supporting laid off employees } \\
\text { talent development } \\
\text { talent identification } \\
\text { university collaboration } \\
\text { work life balance }\end{array}$ & 12 & $\begin{array}{l}\text { Altruistic } \\
\& \\
\text { strategic }\end{array}$ \\
\hline Corporate governance & $\begin{array}{l}\text { compliance with regulations ( } 2 \text { ) } \\
\text { ethics and transparency (4) } \\
\text { responsibility and accountability }\end{array}$ & 7 & Strategic \\
\hline Health \& hygiene & health and hygiene (7) & 7 & Altruistic \\
\hline $\begin{array}{l}\text { Innovation \& } \\
\text { technology }\end{array}$ & $\begin{array}{l}\text { innovation (4) } \\
\text { technological innovation (2) }\end{array}$ & 6 & Strategic \\
\hline $\begin{array}{l}\text { Infrastructure } \\
\text { development }\end{array}$ & $\begin{array}{l}\text { infrastructure building } \\
\text { supporting microenterprise }\end{array}$ & 2 & Strategic \\
\hline \multicolumn{2}{|l|}{ Total } & 151 & \\
\hline
\end{tabular}

It may be noted that the MNC listed above focuses on social development, education and skill development, invested in processes for efficient manufacturing operations, care for the environment, stakeholder engagement, corporate governance, health and hygiene, technological innovation \& infrastructural development.

Key issues addressed are: community development (20) followed by education (10) and skill development (10).

The efforts of MNCs towards a clean environment (8) occupy the third place followed by health and hygiene (7) and sustainable use of resources (5).

Majority (63\%) of efforts are directed at social, education \& skill and manufacturing operations. 


\subsubsection{Thematic analysis of data from Indian private companies}

Thematic analysis of Corporate sustainability and CSR initiatives of Indian private companies are given in table 19 below:

Table 19 : Thematic analysis of data from Indian private companies

\begin{tabular}{|c|c|c|c|}
\hline $\begin{array}{l}\text { Themes derived } \\
\text { from Indian private } \\
\cos (n=11)\end{array}$ & Categories/subcategories & Frequency & $\begin{array}{l}\text { Type of } \\
\text { CS/CSR }\end{array}$ \\
\hline Social development & $\begin{array}{l}\text { caring underprivileged (2) } \\
\text { charity service } \\
\text { community development (7) } \\
\text { culture (2) } \\
\text { distributing free meals (2) } \\
\text { philanthropy } \\
\text { poverty alleviation } \\
\text { public private partnership (2) } \\
\text { rural development (2) } \\
\text { rural girl child education initiative } \\
\text { sports (2) } \\
\text { supporting farmers (6) } \\
\text { volunteering }\end{array}$ & 30 & Altruistic \\
\hline Environment & $\begin{array}{l}\text { afforestation } \\
\text { environment clean up } \\
\text { green building (2) } \\
\text { green environment ( } 2 \text { ) } \\
\text { green projects } \\
\text { pollution control } \\
\text { recycling } \\
\text { reduction in carbon footprints (2) } \\
\text { water treatment }\end{array}$ & 12 & $\begin{array}{l}\text { Altruistic } \\
\& \\
\text { strategic }\end{array}$ \\
\hline $\begin{array}{l}\text { Manufacturing } \\
\text { operations }\end{array}$ & $\begin{array}{l}\text { clean process } \\
\text { cost efficient manufacturing } \\
\text { effluent treatment } \\
\text { emission reduction } \\
\text { positive water balance } \\
\text { productivity } \\
\text { quality } \\
\text { water management (2) } \\
\text { workplace safety }(2) \\
\text { responsible sourcing }\end{array}$ & 12 & Strategic \\
\hline $\begin{array}{l}\text { Education \& skill } \\
\text { building }\end{array}$ & $\begin{array}{l}\text { education (6) } \\
\text { scholarships } \\
\text { skill development (3) }\end{array}$ & 10 & Altruistic \\
\hline
\end{tabular}




\begin{tabular}{|c|c|c|c|}
\hline Health \& hygiene & $\begin{array}{l}\text { blood donation camps } \\
\text { healthcare initiatives (5) } \\
\text { sanitation } \\
\text { water }\end{array}$ & 8 & Altruistic \\
\hline Energy conservation & $\begin{array}{l}\text { ecofriendly technology } \\
\text { energy efficient process } \\
\text { minimizing energy wastage } \\
\text { renewable energy (3) } \\
\text { wind energy }\end{array}$ & 7 & Strategic \\
\hline $\begin{array}{l}\text { Stakeholder } \\
\text { engagement }\end{array}$ & $\begin{array}{l}\text { multiple stakeholders } \\
\text { philanthropy foundation } \\
\text { stakeholder engagement (2) } \\
\text { team work } \\
\text { trusteeship management } \\
\text { transparency }\end{array}$ & 7 & $\begin{array}{l}\text { Altruistic } \\
\& \\
\text { strategic }\end{array}$ \\
\hline Disaster relief & $\begin{array}{l}\text { disaster relief ( } 3 \text { ) } \\
\text { flood relief } \\
\text { relief operations }\end{array}$ & 5 & $\begin{array}{l}\text { Altruistic } \\
\& \\
\text { strategic }\end{array}$ \\
\hline Infrastructure & $\begin{array}{l}\text { infrastructure development (2) } \\
\text { urban development }\end{array}$ & 3 & Strategic \\
\hline \multicolumn{2}{|l|}{ Total } & 94 & \\
\hline
\end{tabular}

From the table above, it may be indicated that the Indian private companies in this study prioritize on the following areas of corporate sustainability and CSR: social development, manufacturing operations, environment, education \& skill building, health \& hygiene, energy conservation, stakeholder engagement, disaster relief and infrastructure development.

Key issues addressed are: community development (7), supporting farmers (6), education (6) and healthcare (5). Majority (57\%) of efforts of Indian private companies are directed towards social development, environment and manufacturing operations. 


\subsubsection{Thematic analysis of data from Indian public sector enterprises}

Thematic analysis of Corporate sustainability and CSR initiatives of Indian public sector Enterprises are given in table 20 below:

Table 20 : Thematic analysis of data from public sector enterprises

\begin{tabular}{|c|c|c|c|}
\hline $\begin{array}{l}\text { Themes derived } \\
\text { from data of PSEs }\end{array}$ & Categories/subcategories & Frequency & $\begin{array}{l}\text { Type of } \\
\text { CS/CSR }\end{array}$ \\
\hline Environment & $\begin{array}{l}\text { afforestation (3) } \\
\text { developing greenbelt } \\
\text { environmental protection } \\
\text { pollution control (5) } \\
\text { rain water harvesting (4) } \\
\text { reducing carbon footprints } \\
\text { restoration of ecosystem } \\
\text { smokeless fuel } \\
\text { water management (3) }\end{array}$ & 20 & $\begin{array}{l}\text { Altruistic } \\
\& \\
\text { strategic }\end{array}$ \\
\hline Social development & $\begin{array}{l}\text { community development (7) } \\
\text { disability toolkits for differently } \\
\text { abled } \\
\text { farmer support (2) } \\
\text { livelihood generation } \\
\text { rights of indigenous people } \\
\text { saving street children } \\
\text { supporting physically challenged } \\
\text { supporting underprivileged (3) } \\
\text { women empowerment }\end{array}$ & 18 & Altruistic \\
\hline $\begin{array}{l}\text { Education \& skill } \\
\text { building }\end{array}$ & $\begin{array}{l}\text { education (5) } \\
\text { scholarships (2) } \\
\text { skill development (11) }\end{array}$ & 18 & Altruistic \\
\hline Energy conservation & $\begin{array}{l}\text { eco-ventilation system } \\
\text { energy conservation (3) } \\
\text { renewable energy (11) }\end{array}$ & 15 & $\begin{array}{l}\text { Altruistic } \\
\& \\
\text { strategic }\end{array}$ \\
\hline Sanitation & $\begin{array}{l}\text { clean drinking water (4) } \\
\text { construction of toilets } \\
\text { pay \& use toilet } \\
\text { sanitation }\end{array}$ & 7 & Altruistic \\
\hline Healthcare & $\begin{array}{l}\text { healthcare (4) } \\
\text { HIV AIDS awareness campaign }\end{array}$ & 5 & Altruistic \\
\hline $\begin{array}{l}\text { Manufacturing } \\
\text { operations }\end{array}$ & $\begin{array}{l}\text { low emission drive in } \\
\text { manufacturing process } \\
\text { waste to energy conversion } \\
\text { waste water treatment }\end{array}$ & 3 & Strategic \\
\hline Stakeholder & cash awards to meritorious & 2 & Strategic \\
\hline
\end{tabular}




\begin{tabular}{|c|c|c|c|}
\hline engagement & $\begin{array}{l}\text { children of employees } \\
\text { educated and healthy workforce }\end{array}$ & & \\
\hline Infrastructure & $\begin{array}{l}\text { infrastructure } \\
\text { night shelter }\end{array}$ & 2 & Strategic \\
\hline Disaster relief & $\begin{array}{l}\text { prefabricated dwelling units for } \\
\text { victims of earthquake } \\
\text { rehabilitation of disaster victims }\end{array}$ & 2 & $\begin{array}{l}\text { Altruistic } \\
\& \\
\text { strategic }\end{array}$ \\
\hline \multicolumn{2}{|l|}{ Total activities } & 92 & \\
\hline
\end{tabular}

From the table above, it may be suggested that the samples of companies in the Indian public sector enterprises direct their corporate sustainability and CSR efforts towards environment, social development, education \& skill building, energy conservation, sanitation, healthcare, manufacturing operations, stakeholder engagement, infrastructure development and disaster relief.

Key issues identified are skill development (11), renewable energy generation (11), community development (7), pollution control (5), education (5), rainwater harvesting (4), providing clean drinking water (4) and healthcare (4). Majority (61\%) of the efforts of PSEs in this study addresses issues related to environment, social development and education \& skill building.

\subsubsection{Comparison of CS \& CSR among clusters of companies}

The effectiveness ratios among clusters of companies in the study are in the order: PSEs > Indian Private > MNCs. This correlates in both absolute as well as relative values. In relative terms, the focus of clusters of companies under study are as follows:

MNCs : Social (23.17), education \& skill (22.51), manufacturing (17.21); Indian Private : Social (31.91), environment (12.76), manufacturing (12.76). PSEs : Environment (21.73), social (19.56), and education \& skill (19.56). The relative performance of CS and CSR per company is in the following order PSES > Indian private $>$ MNCs given by corresponding ratios $2.70: 2.18: 1$. 
Table 21: Comparison of CS and CSR activities among MNCs, Indian private companies and PSEs

\begin{tabular}{|c|c|c|c|c|c|c|c|c|c|c|c|}
\hline \multirow{2}{*}{$\begin{array}{l}\text { Multinational } \\
\text { companies } \\
\text { Themes }\end{array}$} & \multicolumn{3}{|c|}{ Frequency } & \multirow{2}{*}{$\begin{array}{l}\text { Indian private companies } \\
\text { Themes }\end{array}$} & \multicolumn{3}{|c|}{ Frequency } & \multirow{2}{*}{$\begin{array}{l}\text { Public sector enterprises } \\
\text { Themes }\end{array}$} & \multicolumn{3}{|c|}{ Frequency } \\
\hline & Abso & Relat & $\mathrm{Av} / \mathrm{co}$ & & Abso & Relat & $\mathrm{Av} / \mathrm{co}$ & & Abso & Relat & $\mathrm{Av} / \mathrm{co}$ \\
\hline Social development & 35 & 23.17 & 0.96 & Social development & 30 & 31.91 & 2.90 & Environment & 20 & 21.73 & 2.71 \\
\hline $\begin{array}{l}\text { Education \& skill } \\
\text { building }\end{array}$ & 34 & 22.51 & 0.93 & Environment & 12 & 12.76 & 1.16 & Social development & 18 & 19.56 & 2.44 \\
\hline $\begin{array}{l}\text { Manufacturing } \\
\text { operations }\end{array}$ & 26 & 17.21 & 0.71 & $\begin{array}{l}\text { Manufacturing } \\
\text { operations }\end{array}$ & 12 & 12.76 & 1.16 & Education \& Skill building & 18 & 19.56 & 2.44 \\
\hline Environment & 22 & 14.56 & 0.60 & Education \& skill building & 10 & 10.63 & 0.96 & Energy conservation & 15 & 16.30 & 2.03 \\
\hline $\begin{array}{l}\text { Stakeholder } \\
\text { engagement }\end{array}$ & 12 & 7.94 & 0.33 & Health \& hygiene & 8 & 8.51 & 0.77 & Sanitation & 7 & 7.60 & 0.95 \\
\hline Corporate governance & 7 & 4.63 & 0.19 & Energy conservation & 7 & 7.44 & 0.67 & Healthcare & 5 & 5.43 & 0.67 \\
\hline Health \& hygiene & 7 & 4.63 & 0.19 & Stakeholder engagement & 7 & 7.44 & 0.67 & Manufacturing operations & 3 & 3.26 & 0.40 \\
\hline $\begin{array}{l}\text { Innovation \& } \\
\text { technology }\end{array}$ & 6 & 3.97 & 0.16 & Disaster relief & 5 & 5.31 & 0.48 & Stakeholder engagement & 2 & 2.17 & 0.27 \\
\hline $\begin{array}{l}\text { Infrastructure } \\
\text { development }\end{array}$ & 2 & 1.32 & 0.05 & $\begin{array}{l}\text { Infrastructure \& urban } \\
\text { development }\end{array}$ & 3 & 3.19 & 0.29 & $\begin{array}{l}\text { Infrastructure } \\
\text { development }\end{array}$ & 2 & 2.17 & 0.27 \\
\hline- & - & - & - & - & - & - & - & Disaster relief & 2 & 2.17 & 0.27 \\
\hline No. of activities (total) & 151 & 100 & 4.16 & & 94 & 100 & 9.08 & & 92 & 100 & 12.49 \\
\hline No. of companies & 24 & 24 & 1 & & 11 & 11 & 1 & & 8 & 8 & 1 \\
\hline No. of themes & & & 9 & & & & 9 & & & & 10 \\
\hline $\begin{array}{l}\text { Average theme } \\
\text { /company }\end{array}$ & & & 0.46 & & & & 1.00 & & & & 1.24 \\
\hline Effectiveness ratio & & & 1 & & & & 2.18 & & & & 2.70 \\
\hline
\end{tabular}

(Note: Abso-Absolute scale; Relat- Relative scale; Av/co-Average/company)

The above table depicts themes obtained (after coding and categorization of the qualitative data) for MNCs, Indian private and

PSEs respectively. The themes are listed in descending order for each of the cluster group of companies. In order to compare the cluster groups of companies, the absolute values of frequencies are converted to relative value.

(The comparison among clusters in specific categories are given in section 7.2.1 under chapter 7) 


\subsection{Benefits of corporate sustainability \& CSR}

A new era of social consciousness is evolving throughout the world. Over the last 20 years, the brand management has evolved from functional centric brands to emotional centric brands, and has progressed to value-centric brands. It is the responsibility of brand manager to create brands that inspire the society. There is a need to create brands that address social issues. It is no longer enough for brands to define themselves in terms of what they are: they must make a statementenvironmentally, culturally, and socially-about what they want to be. An advantage of corporate initiatives is that unlike in the traditional brand marketing domain, a firm's intangible assets, when strategically deployed can be marketed not only to the customers who use the brand but also to other stakeholders who are involved directly or indirectly with the brand. Clearly, measures of intangible assets and their dependencies are gaining importance. Thus, several companies use CSR as a means to enhance the image, generate brand equity and employee loyalty.

Free and open market encourages competition among brands and companies, which gives rise to innovations in manufacturing processes and marketing strategies. Brand managers are compelled to differentiate their brands by bringing in intangible assets of the company or the brand and incorporate them in brand communication strategy. Incorporating these intangible assets- brand identity, reputation, goodwill or being a good corporate citizen into their marketing initiatives support an organization gain sustainable competitive advantage. The companies are encouraged to adopt and expand CSR efforts in order to satisfy customers, employees, communities, investors, activist organizations and other stakeholders, thus resulting in the growth of CSR activities. The companies have experienced a range of benefits from being engaged in CSR which includes improved financial performance, reduced operating costs and increased sales and customer loyalty.

A number of studies conducted in the past reflect a positive association between CSR and financial performance (Ruf et al. 2001). A company considered socially 
responsible gets benefited both by its enhanced reputation among the public and the business community. Social action programs create a favourable public image (Rashid \& Ibrahim 2002). Hindustan Unilever Ltd. (HUL) through its Surf Excel brand gained an immeasurable reputation in the course of its campaign of education to poor children. In a survey conducted by Confederation of Indian Industry (2002), a majority of corporate respondents perceived that CSR lead to improved brand image.

The companies implementing CSR find it comparatively easy to recruit and retain the skilled employees for a sufficiently long period of time; these are important criteria for the success of the company (Krishna 1992). This is empirically tested and proven by Turban \& Greening (1996) that "corporate social responsibility is positively related to a firm's attractiveness." In a study conducted by Luce et al. (2001), it was evident that "corporate social performance is positively related to a firm's familiarity which in turn affects organizational attractiveness as an employer. Consumers expect the firms to conduct business ethically and expressed their willingness to reward ethical behavior through purchase response."

Customers prefer to purchase products of companies that are conscious about CSR. As a result, companies are shifting their business strategy from product to value to the society. This value driven strategy enables companies to communicate to customers with transparency on their processes, and involve customers in an interaction. 'It may be observed that several companies, for example, Nike and Hewlett-Packard, have published information on their supply chain system online. This openness generates trust, which in turn is translated into value for the company (Segran 2010). Corporations, often are willingly engage in socially responsible behavior precisely because it enhances shareholder value. Moreover, management believes that such activities create goodwill among customers in excess of their price tag (Martin 2002). 
Those organizations proactively and strategically building their "Social Brand Capital" reap the benefits of CSR. Social Brand Capital (SBC) is the loyalty value that stakeholders attribute to a company's brand as a result of the company's commitment to the social/ environmental cause. As Michael Porter and Mark Kramer recently stated, "adding a social dimension to the value proposition extends a new dimension in competitive positioning" (Porter\& Kramer 2006). GE and FedEx are examples of companies in this stage of building their SBC. "FedEx introduced a delivery truck running on a hybrid electric engine that could become a standard medium duty truck segment in FedEx's fleet. This hybrid engine is environment friendly and reduces particulate emission by $90 \%$, emission due to smog by $75 \%$ and increases fuel efficiency by 50\%" (FedEx 2003). GE's 'ecoimagination' project is infusing US\$1.5 billion into developing ecologically responsible innovation that will reduce greenhouse emissions" (Simmons 2010).

CS and CSR helps in increasing market share; achieving market penetration into new markets and segments; bringing about goodwill and transforming the public perception favourable towards an organization and industry. In fact, organizations may be successful in creating customer loyalty, generating profits through higher market share if they demonstrate their CSR practices as a unique differentiator (Balasubramanian 2007). 


\section{CHAPTER 6}

DIMENSIONS OF STRATEGIC CSR AND RESPONSIBILITIES OF COMPANIES OPERATING IN INDIA (QUANTITATIVE STUDY)

\subsection{Introduction}

This chapter provides information on second part of the study (quantitative research). The completed questionnaires 2 and 3 received from respondents were collected and evaluated to identify the relationship between independent variables and dependent variable.

The study examines conditions under which strategic corporate social responsibility (CSR) is related to value creation of firms.

i. The dimensions of strategic CSR - centrality, specificity, proactivity, visibility and voluntarism among multinational companies, Indian private companies and Indian public sector enterprises were recorded.

ii. The responsibilities of companies - economic, legal, ethical, philanthropy along with charity, stewardship and environmental friendliness among MNCs, Indian private companies and PSEs were recorded in the following sections.

The views of respondents on 'dimensions of strategic CSR' and 'responsibilities of companies' are provided in tables given in Annexure IV.

Quantitative analysis is undertaken starting with descriptive statistics followed by correlation analyses to identify significant relationships among the variables under study (tables 12 and 13 under Chapter 4). Regression analysis 1, factor analysis and regression analysis 2 are undertaken and results tabulated as described in this chapter. 


\subsection{Descriptive statistics}

Information gathered from the questionnaires 2 and 3 are collected, and the data entered into SPSS software. Descriptive statistics showing mean, standard deviation, and percentiles of all the 93 companies under study as shown in table 22 below.

Table 22: Descriptive statistics- Mean, standard deviation (SD) and percentiles

\begin{tabular}{|l|l|l|l|l|l|l|l|}
\hline \multirow{2}{*}{ CSR parameters } & \multicolumn{5}{|c|}{ Total 93 companies } \\
\cline { 2 - 7 } & Mean & SD & p25 & p50 & p75 & Maximum \\
\hline Independent variables - Dimensions of strategic CSR \\
\hline Centrality & 85.12 & 18.00 & 75.00 & 91.66 & 100 & 100.00 \\
\hline Specificity & 83.06 & 20.24 & 75.00 & 100.00 & 100.00 & 100.00 \\
\hline Proactivity & 84.54 & 15.35 & 71.87 & 87.50 & 93.75 & 100.00 \\
\hline Visibility & 52.41 & 23.97 & 37.50 & 62.50 & 68.75 & 100.00 \\
\hline Voluntarism & 56.18 & 14.43 & 50.00 & 56.25 & 68.75 & 81.25 \\
\hline Independent variables - Responsibilities of companies & & \\
\hline $\begin{array}{l}\text { Economic } \\
\text { responsibility }\end{array}$ & 56.65 & 21.21 & 37.50 & 56.25 & 68.75 & 100.00 \\
\hline Legal responsibility & 71.84 & 8.57 & 68.75 & 75.00 & 75.00 & 87.50 \\
\hline Ethical responsibility & 73.31 & 8.94 & 68.75 & 75.00 & 75.00 & 87.50 \\
\hline Philanthropy & 86.42 & 15.97 & 75.00 & 93.75 & 100.00 & 100.00 \\
\hline Charity principle & 78.69 & 18.82 & 68.75 & 81.25 & 100.00 & 100.00 \\
\hline Stewardship & 88.91 & 17.34 & 87.50 & 100.00 & 100.00 & 100.00 \\
\hline $\begin{array}{l}\text { Environmental } \\
\text { friendliness }\end{array}$ & 95.76 & 9.67 & 96.87 & 100.00 & 100.00 & 100.00 \\
\hline Dependent variable & 58.60 & 26.17 & 40.62 & 62.50 & 75.00 & 100.00 \\
\hline Value creation & & & & & & \\
\hline & & & & & \\
\hline
\end{tabular}


From the above table 22, the following observations may be recorded.

Centrality

Majority of the MNCs and domestic companies agree that they collaborate with the community projects, protect the environment and support the social cause; and these coincide with the firms' mission (Mean $=85.12, S D=18.00$ ).

Specificity

Majority of the MNCs and domestic organizations agree with the statement 'fulfillment of the firm's social objectives is necessary to achieve its profit objectives' (Burke \& Logsdon 1996) $($ Mean $=83.06, S D=20.24)$.

Proactivity

Proactivity supports the forward thinking strategies that organizations undertake in order to meet the societal expectations. The survey conducted among various multinational corporations and domestic companies reflect that a significant number of organizations agree fully or agree to a great extent that they take active steps to look ahead and plan their strategies based on a future outlook (Mean $=84.54, \mathrm{SD}=$ 15.35).

Visibility

By creating favorable media attention, strategic CSR initiative should build image of the firms. Negative visibility is mitigated through CSR initiatives. CSR initiatives help in protecting reputation of firm from being tarnished and also help protect from governmental investigations and regulations. The survey revealed that there is an almost even split among various organizations that were a part of the survey, with about a quarter of the organizations disagreeing that they participate in social programmes in order to improve the image of the firm. The rest of the organizations 
admit to various degrees that they do take part in such programs in order to increase the image of the firm (Mean $=52.41, \mathrm{SD}=23.97$ ).

\section{Voluntarism}

Voluntarism is an important part of the corporate social responsibility. The survey among the organizations indicates that majority of organizations do take part in voluntary activities. However, the results of the survey confirm that these organizations take part voluntarily in order to support a social cause and they disagree that they do it so as to get tax benefit or to just fulfill their legal obligations (Mean $=56.18, \mathrm{SD}=14.43)$.

Economic responsibility

The economic responsibility is the foundation of a firm. A company needs to provide goods or services demanded by customers at a reasonable price, and at the same time create efficient processes in order to generate profits. The profits thus generated eventually ensure endurance. Therefore, the researcher probed into the organizations regarding the type of economic responsibility that they believe in. The results indicate that majority of the organizations agree that profitability for the organization and their stakeholders is a high priority (Mean $=56.65, \mathrm{SD}=21.21$ ).

Legal responsibility

Legal responsibility refers to the guidelines that organizations are supposed to adhere to in the process of their business operations. Companies are not allowed to engage in illegal practices to generate profits; they have to obey the law. The boundaries set by the government encompass the legal responsibilities of a firm, and are dependent on the country in which the firm conducts business (Matten \& Moon 2008). The survey probed the organizations on the limits of legal responsibility. The results indicate that most of organizations believe in the legal system and also stated that they follow the rules to the book (Mean $=71.84, \mathrm{SD}=8.57$ ). 
Ethical responsibility

According to Carroll (1991), the businesses have to be accountable to both the government and the society. Societies and cultures develop ethical norms and standards over a period of time, and identify the type of corporate behavior they expect or prohibit. The ethical responsibility should direct the firms to do no harm but to do what is right, just and fair although it is not obeyed by the law. This view is also shared by most of the organizations in the survey. The results indicate that ethical responsibility is important and organizations should not compromise on this front $($ Mean $=73.31, S D=8.94)$.

Philanthropy

The philanthropy refers to the generosity of an organization. In this study, a philanthropic view of CSR is also considered since these responsibilities represent true intrinsically motivated activities of the firm. Individuals generally appreciate the philanthropic actions although though they are not compulsorily required by the society. The results of survey show that most of the organizations do believe in philanthropic responsibility to the communities, promote voluntarism, thus providing for betterment of the community (Mean $=86.42, S D=15.97$ ).

Charity principle

A tendency to charity was observed among the organizations during the course of the survey. Charity is an important part of giving back to the society. This helps the company in its growth and development and in creating a favourable image.

Therefore, this aspect was also considered in the survey. The results reveal that most organizations do agree to a great extent that businesses must help the society (Mean $=78.69, \mathrm{SD}=18.82$. 


\section{Stewardship}

Stewardship refers to loyalty, responsibility, devotion and care to the society or the institution (Donaldson 1990). Stewardship principle suggests that the managers and the business owners act as stewards, investing generously in order to maximize returns to the stakeholders and the society. The survey contained questions on promoting social benefits, considering interests of all those affected by the decisions and actions of the company, balancing the needs of societal groups, and interdependence of business and society. The results reflect that majority of the organizations agree to a great extent that business should be steward to the stakeholders and the society (Mean $=88.91, \mathrm{SD}=17.34)$.

\section{Environment friendliness}

Environment friendliness is an important topic among the business sector. A global awareness towards attaining a greener economy/environment places various aspects of doing business under the spotlight. Companies are being urged to audit their business operations, reduce wastages and adopt various measures to ensure a clean and safe environment. The survey contained questions on different aspects of maintaining a green environment and the results reflect that almost all the organizations in the survey agree to a great extent that steps must be taken to ensure a green environment (Mean $=95.76, \mathrm{SD}=9.67)$.

\section{Value creation}

The survey considered the factors that influence customers' buying decisions, developing new products and services, acquiring new customers or entering into new markets, etc., into account. The results indicate that a majority of organizations do admit that they engage in social responsibilities in an effort to create value for themselves (Mean = 58.60, SD = 26.17) 


\subsection{Correlation analyses}

In this section, the research attempts to identify relationships between different variables under study, keeping in mind the format of the questionnaires 2 and 3. Correlation analyses were performed comparing the attributes of one set of the variable with another set of variable (tables 12 and 13 given under 4.7 variables in chapter 4) and to determine the significance between these two sets of attributes.

\subsubsection{Correlation analysis of variables in dimensions of strategic CSR and value creation}

Table 23 depicts correlation analysis amongst the variables centrality, specificity, proactivity, visibility, voluntarism, and value creation.

Low positive and very significant correlation has been reported between proactivity and specificity $\left(.460^{* *}\right)$, visibility and value creation $\left(.410^{* *}\right)$, proactivity and centrality $\left(.406^{* *}\right)$, specificity and centrality $\left(.395^{* *}\right)$, and visibility and proactivity $\left(.313^{* *}\right)$.

Very low positive and very significant correlation has been reported between centrality and value creation $(.290 * *)$.

Very low positive and significant correlation has been reported between specificity and value creation $\left(.207^{*}\right)$, and proactivity and value creation $\left(.222^{*}\right)$.

This shows that these four attributes- centrality, specificity, proactivity, visibility have a lot in common or are correlated with each other. However, voluntarism is not significant with respect to any other attributes. Centrality, specificity, proactivity, and visibility have a significant relationship with value creation. 
Table 23: Correlation analysis of variables in dimensions of strategic CSR \& value creation

$\begin{aligned} & \text { Table 23: Correlation analysis of variables in } \\
& \text { dimensions of strategic CSR \& value creation }\end{aligned}$
\begin{tabular}{|l|c|c|c|c|c|c|}
\hline 1. Centrality & 1 & 2 & 3 & 4 & 5 & 6 \\
\hline 2. Specificity & 1 & & & & & \\
\hline 3. Proactivity & $.395^{* *}$ & 1 & & & & \\
\hline 4. Visibility & $.406^{* *}$ & $.460^{* *}$ & 1 & & & \\
\hline 5. Voluntarism & .032 & .015 & $.313^{* *}$ & 1 & & \\
\hline 6. Value creation & -.006 & .002 & -.041 & .101 & 1 & \\
\hline
\end{tabular}
**. Correlation is significant at the 0.01 level (2-tailed)

Table 24: Correlation analysis of variables in responsibilities of companies \& value creation

\begin{tabular}{|l|c|}
\hline 1. Economic responsibility & 1 \\
\hline 2. Legal responsibility & $.362^{* *}$ \\
\hline 3. Ethical responsibility & .129 \\
\hline 4. Philanthropy & $.494^{* *}$ \\
\hline 5. Charity principle & .045 \\
\hline 6. Stewardship & $.279^{* *}$ \\
\hline 7. Environmental friendliness & $.356^{* *}$ \\
\hline 8. Value creation & .148 \\
\hline
\end{tabular}

**. Correlation is significant at the 0.01 level (2-tailed).

*. Correlation is significant at the 0.05 level (2-tailed)

\begin{tabular}{|c|c|c|c|c|c|c|c|}
\hline 1 & 2 & 3 & 4 & 5 & 6 & 7 & 8 \\
\hline \multicolumn{8}{|l|}{1} \\
\hline $.362^{* *}$ & 1 & & & & & & \\
\hline .129 & $.456^{* *}$ & 1 & & & & & \\
\hline $.494^{* *}$ & $.241^{*}$ & .121 & 1 & & & & \\
\hline .045 & .063 & .027 & $.458^{* *}$ & 1 & & & \\
\hline $.279^{* *}$ & $.233^{*}$ & .183 & $.680^{* *}$ & $.425^{* *}$ & 1 & & \\
\hline $.356^{* *}$ & $.298^{* *}$ & $.329^{* *}$ & $.602^{* *}$ & $.413^{* *}$ & $.757^{* *}$ & 1 & \\
\hline .148 & -.101 & -.130 & $.245^{*}$ & .188 & $.288^{* *}$ & $.427^{* *}$ & 1 \\
\hline
\end{tabular}

*. Correlation is significant at the 0.05 level (2-tailed). 


\subsubsection{Correlation analysis of variables in responsibilities of companies and value creation}

Table 24 depicts the correlation analysis amongst the variables of responsibilities of companies which include corporate responsibilities (economic responsibility, legal responsibility, ethical responsibility, philanthropy), components of CSR (charity principle, stewardship, environment friendliness), and value creation.

High positive and very significant correlation is achieved between environment friendliness and stewardship $\left(0.757^{* *}\right)$.

Moderate positive and very significant correlation is achieved between philanthropy and stewardship $\left(.680^{* *}\right)$, environment friendliness and philanthropy $\left(.602^{* *}\right)$. Low positive and very significant correlation is achieved between economic responsibility and philanthropy (.494), philanthropy and charity $\left(.458^{* *}\right)$, ethical responsibility and legal responsibility $\left(.456^{* *}\right)$, environmental friendliness and value creation $\left(.427^{* *}\right)$, charity and stewardship $\left(.425^{* *}\right)$, charity principle and environmental friendliness $\left(.413^{* *}\right)$, economic responsibility and legal responsibility $\left(.362^{* *}\right)$, economic responsibility and environmental friendliness $\left(.356^{* *}\right)$,and ethical responsibility and environmental friendliness $\left(.329^{* *}\right)$.

Very low positive and very significant correlation has been reported between legal responsibility and environmental friendliness $\left(.298^{* *}\right)$, stewardship and value creation $\left(.288^{* *}\right)$, and economic responsibility and stewardship $\left(.279^{* *}\right)$.

Very low positive and significant correlation has been reported between legal responsibility and philanthropy $\left(.241^{*}\right)$, philanthropy and value creation $\left(.245^{*}\right)$, and legal responsibility and stewardship $\left(.233^{*}\right)$.

It is vital to note that environmental friendliness is related to all the variables considered with a highly significant value. It has also been observed that value creation is significantly related to only three independent variables philanthropy, stewardship and environmental friendliness. 


\subsection{Regression model 1 (R1)}

\section{A. Multinational companies (MNCs)}

On examining the output of regression analysis, the F-value 13.927 is significant ( $p$ value $=0.00$ ). The $R$-square is 0.908 which means that $90.8 \%$ of variability in value creation is accounted for by the variables in the model. The adjusted R-square shows that $84.2 \%$ of variability in value creations is accounted for by the model, after taking into account the number of predictor variables. The Durbin Watson statistic of 1.602 suggests that the residuals are independent. Several independent variables are significant as shown under the regression model 1 (Annexure V)

The above regression model is tested for normality, linearity, to detect heteroscedasticity, autocorrelation and multicollinearity. On observing the plotted graph of ZPRED on $x$-axis and ZRESID on $y$-axis, it may be suggested that there is no pattern. Therefore, we presume that the graph is said to be homogeneous and has no heteroscedasticity (Annexure V). It has been observed that the model suffers from multicollinearity. The VIF is greater than 10 for several variables, as shown in table 25. Therefore, multicollinearity has to be corrected.

Rule of thumb to identify multicollinearity:

Tolerance less than 0.5 reflect that the model suffers from multicollinearity. The requirement is to make tolerance of at least 0.5

If the VIF is less than 10 , there exists no multicollinearity whereas multicollinearity is present for VIF values greater than 10.

In order to prevent multicollinearity, ensure that Eigen value should approximately be 0 . If the Condition Index is $>15$, there is a possibility that the multicollinearity is not severe. If the Condition Index is $>30$, there is possibility of severe multicollinearity. 
Table 25: Test for multicollinearity among MNCs under Regression 1

\begin{tabular}{|c|c|c|c|c|c|}
\hline S.No & Variables & Tolerance & VIF & Eigen value & Condition Index \\
\hline 1 & Constant & & & 12.636 & 1.000 \\
\hline 2 & Specificity & .015 & 64.606 & .145 & 9.320 \\
\hline 3 & Centrality & .006 & 160.342 & .098 & 11.382 \\
\hline 4 & Proactivity & .048 & 20.943 & .046 & 16.540 \\
\hline 5 & Voluntarism & .004 & 276.071 & .032 & 19.860 \\
\hline 6 & Visibility & .014 & 69.091 & .026 & 22.122 \\
\hline 7 & Economic responsibility & .104 & 9.607 & .006 & 44.284 \\
\hline 8 & Legal responsibility & .004 & 227.286 & .005 & 49.821 \\
\hline 9 & Ethical responsibility & .003 & 300.938 & .004 & 56.181 \\
\hline 10 & Philanthropy & .018 & 56.533 & .001 & 144.709 \\
\hline 11 & Charity principle & .017 & 60.519 & .000 & 222.965 \\
\hline 12 & Stewardship & .012 & 84.554 & 4.487E-005 & 530.682 \\
\hline 13 & Environmental friendliness & .008 & 126.208 & 1.303E-006 & 3113.939 \\
\hline
\end{tabular}

In the above table, the tolerance $<0.5, \mathrm{VIF}>10$, Condition Index $>15$ for almost all of the variables depicting multicollinearity 
Table 26: Regression 1 outcomes among Multinational companies (MNCs)

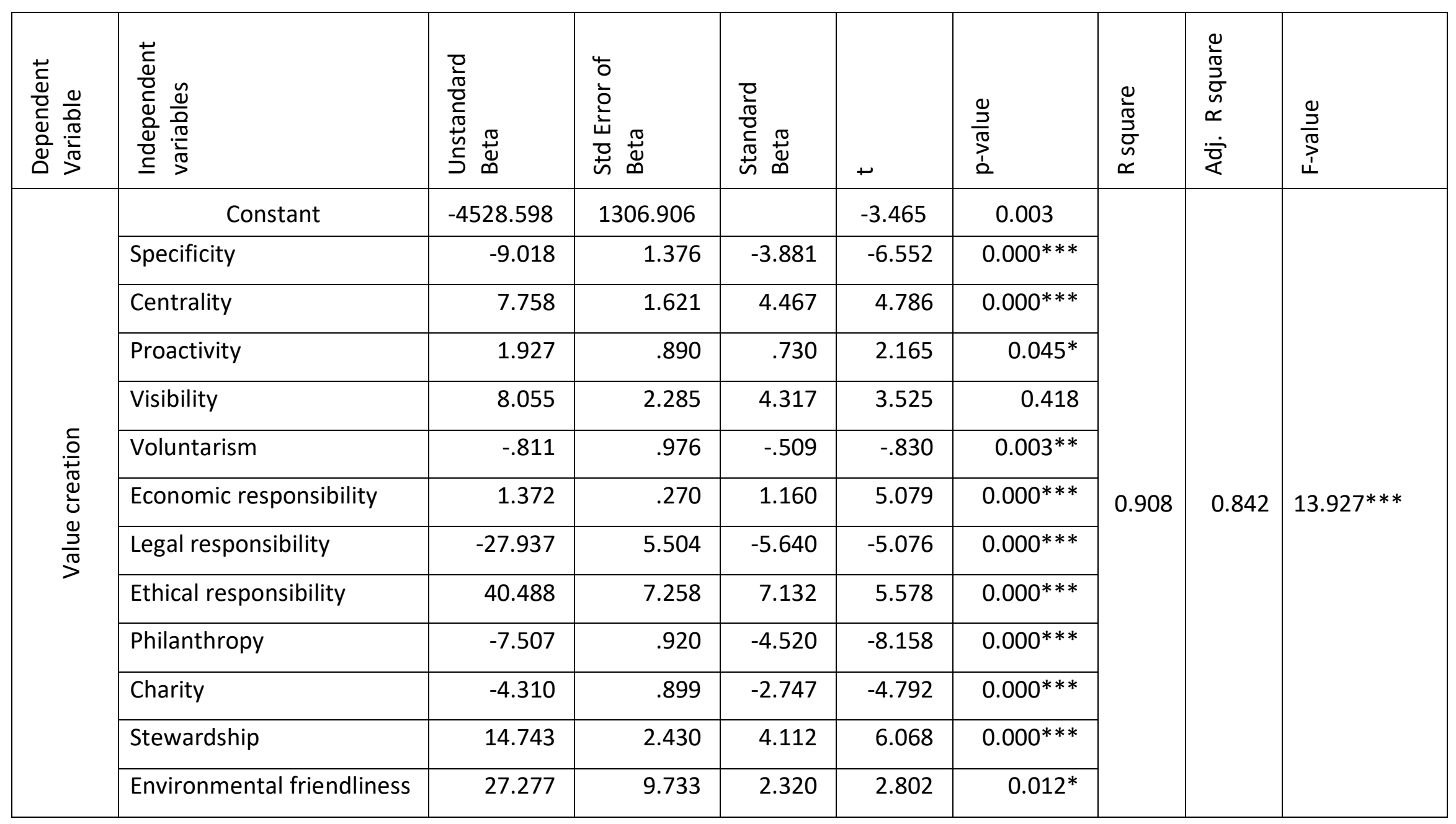

(Companies under MNCs only)

Indicators: *** Sig.<0.001, ** Sig. $<0.01, *$ Sig. $<0.05$, blank Sig. $>0.05$ 
B. Indian private companies (Indian private)

On examining the output of regression analysis, the F-value 102.532 is significant ( $p$ value $=0.00$ ). The $R$-square is 0.990 which means $99 \%$ of variability in value creation is accounted for by the variables in the model. The adjusted R-square shows that $98 \%$ of variability in value creation is accounted for by the model, after taking into account the number of predictor variables. The Durbin Watson statistic 2.024 is good indicator reflecting that the residuals are independent (Annexure V).

The above regression model is tested for normality, linearity, to detect heteroscedasticity, autocorrelation and multicollinearity and the graphs are plotted. On observing the plotted graph of ZPRED on x-axis and ZRESID on y-axis, it may be suggested that there is no pattern. Therefore, we presume that the graph has no heteroscedasticity (Annexure V).

The model suffers from multicollinearity as confirmed from table 27 below. 
Table 27: Test for multicollinearity among Indian private under Regression 1

\begin{tabular}{|l|l|c|c|c|c|}
\hline S.No & Variables & Tolerance & \multicolumn{1}{|c|}{ VIF } & Eigen value & Condition Index \\
\hline 1 & Constant & & & 12.448 & 1.000 \\
\hline 2 & Specificity & .011 & 92.491 & .256 & 6.971 \\
\hline 3 & Centrality & .023 & 42.653 & .098 & 11.284 \\
\hline 4 & Proactivity & .012 & 86.042 & .079 & 12.526 \\
\hline 5 & Voluntarism & .041 & 24.156 & .050 & 15.776 \\
\hline 6 & Visibility & .004 & 229.985 & .032 & 24.754 \\
\hline 7 & Economic responsibility & .015 & 65.503 & .020 & 41.851 \\
\hline 8 & Legal responsibility & .027 & 36.772 & .007 & 43.963 \\
\hline 9 & Ethical responsibility & .069 & 14.502 & .006 & 68.219 \\
\hline 10 & Philanthropy & .003 & 330.953 & .003 & 122.997 \\
\hline 11 & Charity principle & .028 & 35.469 & .001 & 551.874 \\
\hline 12 & Stewardship & .001 & 1098.827 & $4.087 \mathrm{E}-005$ & 866.513 \\
\hline 13 & Environmental friendliness & .005 & 216.113 & $1.658 \mathrm{E}-005$ & \\
\hline
\end{tabular}

In the above table, the tolerance $<0.5, \mathrm{VIF}>10$, Condition Index $>15$ for almost all of the variables depicting multicollinearity 
Table 28: Regression 1 outcomes among Indian private companies (Indian private)

\begin{tabular}{|c|c|c|c|c|c|c|c|c|c|}
\hline 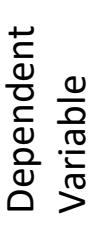 & 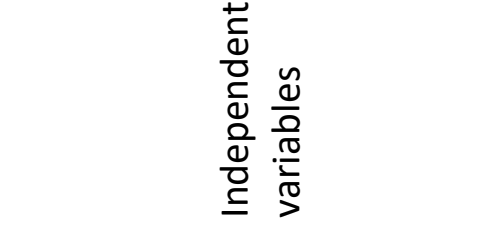 & $\begin{array}{l}\mathbb{D} \\
\stackrel{D}{D}\end{array}$ & 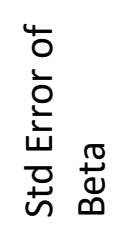 & 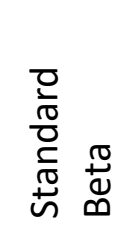 & + & $\begin{array}{l}\frac{0}{2} \\
\frac{2}{\pi} \\
\frac{1}{2} \\
2\end{array}$ & 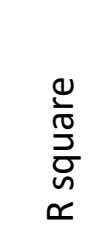 & $\begin{array}{l}\simeq \frac{0}{\frac{0}{0}} \\
\dot{\overline{0}} \frac{\overline{0}}{\overline{0}}\end{array}$ & $\frac{0}{\frac{0}{2}}$ \\
\hline \multirow{13}{*}{$\begin{array}{l}\frac{5}{0} \\
\stackrel{0}{0} \\
\frac{0}{0} \\
\frac{0}{0} \\
\frac{0}{\pi} \\
\frac{1}{7}\end{array}$} & Constant & -176.322 & 58.413 & & -3.019 & .010 & \multirow{13}{*}{0.990} & \multirow{13}{*}{0.980} & \multirow{13}{*}{$102.532 * * *$} \\
\hline & Specificity & 1.036 & .304 & .929 & 3.406 & $.005 * *$ & & & \\
\hline & Centrality & -.128 & .214 & -.111 & -.598 & .560 & & & \\
\hline & Proactivity & -.607 & .369 & -.432 & -1.643 & .124 & & & \\
\hline & Voluntarism & .194 & .179 & .150. & 1.079 & .300 & & & \\
\hline & Visibility & .315 & .358 & .379 & .880 & .395 & & & \\
\hline & Economic responsibility & -1.421 & .252 & -1.292 & -5.630 & $.000 * * *$ & & & \\
\hline & Legal responsibility & .198 & .349 & .097 & .566 & .581 & & & \\
\hline & Ethical responsibility & .256 & .209 & .132 & 1.224 & .243 & & & \\
\hline & Philanthropy & -.502 & .742 & -.349 & -.677 & .510 & & & \\
\hline & Charity & -1.573 & .185 & -1.440 & -8.525 & $.000 * * *$ & & & \\
\hline & Stewardship & -3.889 & 1.338 & -2.732 & -2.906 & $.012 *$ & & & \\
\hline & Environmental friendliness & 7.922 & .778 & 4.245 & 10.182 & $.000 * * *$ & & & \\
\hline
\end{tabular}

(Companies under Indian private only)

Indicators: $* * *$ Sig. $<0.001, * *$ Sig. $<0.01, *$ Sig. $<0.05$, blank Sig. $>0.05$ 


\section{Public sector enterprises (PSEs)}

On examining the output of regression analysis 1, the F-value 10.464 is significant ( $p$ value $=0.00$ ). The R-square is 0.840 which means $84 \%$ of variability in value creation is accounted for by the variables in the model. The adjusted R-square shows that $75.9 \%$ of variability in value creation is accounted for by the model, after taking into account the number of predictor variables. The Durbin Watson statistic 0.914 is a concern indicating that the residuals are not independent. Several independent variables are significant as shown by the regression (Annexure V).

The regression model 1 is tested for normality, linearity, to detect heteroscedasticity, autocorrelation and multicollinearity and the graphs are plotted. On observing the plotted graph of ZPRED on $x$-axis and ZRESID on y-axis, it may be suggested that there is no pattern. Therefore, we observe that the graph does not suffer from heteroscedasticity (Annexure V).

From the above, it may be suggested that the regression model 1 is linear, homogenous and has no autocorrelation. However, it suffers from multicollinearity with high values of VIF values as shown in table 29 below.

There is a need to remove high VIF values.

The next step is to standardize using $\mathrm{z}=(\mathrm{Xi}-\mathrm{X}) / \mathrm{s}$ and data reduction through factor analysis. 
Table 29: Test for multicollinearity among PSEs under Regression 1

\begin{tabular}{|c|c|c|c|c|c|}
\hline S.No & Variables & Tolerance & VIF & Eigen value & Condition Index \\
\hline 1 & Constant & & & 12.449 & 1.000 \\
\hline 2 & Specificity & .132 & 7.549 & .206 & 7.766 \\
\hline 3 & Centrality & .404 & 2.473 & .102 & 11.049 \\
\hline 4 & Proactivity & .101 & 9.916 & .098 & 11.292 \\
\hline 5 & Voluntarism & .342 & 2.924 & .057 & 14.780 \\
\hline 6 & Visibility & .208 & 4.813 & .032 & 19.757 \\
\hline 7 & Economic responsibility & .227 & 4.398 & .023 & 23.397 \\
\hline 8 & Legal responsibility & .289 & 3.465 & .014 & 30.213 \\
\hline 9 & Ethical responsibility & .229 & 4.362 & .009 & 37.349 \\
\hline 10 & Philanthropy & .025 & 40.162 & .006 & 44.029 \\
\hline 11 & Charity principle & .282 & 3.548 & .003 & 68.627 \\
\hline 12 & Stewardship & .059 & 16.854 & .002 & 88.803 \\
\hline 13 & Environmental friendliness & .098 & 10.250 & .000 & 169.168 \\
\hline
\end{tabular}

In the above table, the tolerance $<0.5$, VIF $>10$ for a few variables, Condition Index $>15$ for almost all of the variables depicting multicollinearity 
Table 30: Regression 1 outcomes among public sector enterprises (PSEs)

\begin{tabular}{|c|c|c|c|c|c|c|c|c|c|}
\hline 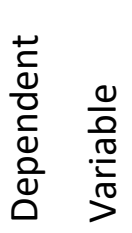 & 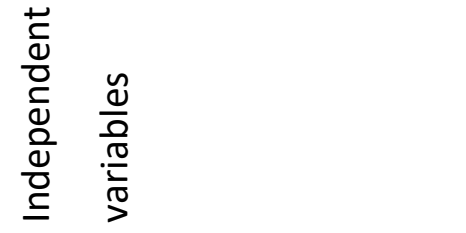 & 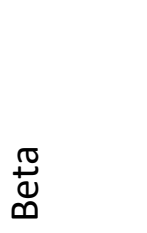 & 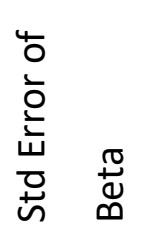 & 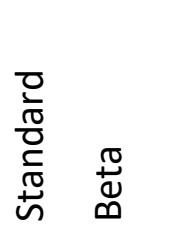 & + & $\begin{array}{l}\frac{0}{2} \\
\frac{2}{\pi} \\
\frac{1}{2}\end{array}$ & $\begin{array}{l}\frac{0}{\frac{1}{0}} \\
\frac{0}{2} \\
0 \\
0 \\
\simeq\end{array}$ & $\begin{array}{ll}\simeq & \frac{0}{2} \\
\dot{\bar{\sigma}} & \frac{0}{\sigma} \\
\end{array}$ & $\frac{0}{\frac{0}{2}}$ \\
\hline \multirow{13}{*}{ 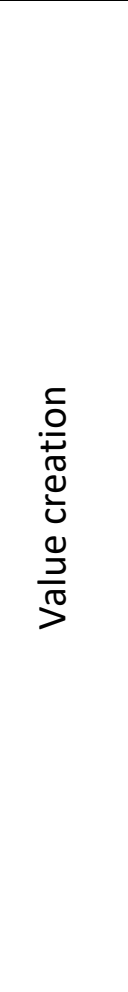 } & Constant & 1.002 & 39.239 & & .026 & 0.980 & \multirow{13}{*}{0.840} & \multirow{13}{*}{0.759} & \multirow{13}{*}{$10.464 * * *$} \\
\hline & Specificity & .008 & .241 & .008 & .034 & 0.973 & & & \\
\hline & Centrality & .458 & .174 & .338 & 2.631 & $0.015^{*}$ & & & \\
\hline & Proactivity & .624 & .392 & .410 & 1.591 & 0.125 & & & \\
\hline & Voluntarism & .758 & .303 & .350 & 2.504 & $0.019 *$ & & & \\
\hline & Visibility & -.102 & .186 & -.098 & -.548 & 0.588 & & & \\
\hline & Economic responsibility & -.305 & .236 & -.222 & -1.292 & 0.208 & & & \\
\hline & Legal responsibility & -1.162 & .463 & -.382 & -2.509 & $0.019 *$ & & & \\
\hline & Ethical responsibility & -1.604 & .502 & -.546 & -3.194 & $0.004^{* *}$ & & & \\
\hline & Philanthropy & -.189 & .839 & -.117 & -.226 & 0.823 & & & \\
\hline & Charity & .252 & .207 & .188 & 1.218 & 0.235 & & & \\
\hline & Stewardship & -.728 & .378 & -.646 & -1.925 & 0.066 & & & \\
\hline & Environmental friendliness & 2.101 & .615 & .894 & 3.413 & $0.002 * *$ & & & \\
\hline
\end{tabular}

(Companies under PSEs only)

Indicators: *** Sig. $<0.001, * *$ Sig. $<0.01, *$ Sig. $<0.05$, blank Sig. $>0.05$ 


\subsection{Factor analyses}

The term 'factor analysis' was introduced for the first time by Thurston in 1931 as a data reduction technique for the purpose of reducing the number of variables and to detect structure in the relationship among the variables. Factor analysis is an investigation process in which a number of variables of interest are linearly related to a small number of unobservable factors. Factor analysis is a correlation method used to analyse and describe underlying factors driving data values for a large set of variables (StatSoft 2013).

There are two types of factor analyses- exploratory factor analysis and confirmatory factor analysis. The exploratory factor analysis is useful in identifying complex interrelationships among items and group items that are part of unified concepts (Polit \& Beck 2012). Confirmatory factor analysis is a complex analysis to test the hypothesis that the items are associated with various factors (Polit \& Beck 2012).

\subsubsection{Factor analysis using SPSS}

Factor analysis is performed using SPSS software by selecting 'Analyse' and following the steps of 'Data reduction' and subsequently 'Factor Analysis'. The dialogue box opens and the variables to be analysed from the study are selected. There are five dialogue boxes namely - descriptive, extraction, rotation, scores and option stated alongside the dialogue box.

The descriptive button refers to the descriptive statistics and correlation matrix. Extraction button allows the researcher to select the type of analysis such as factor analysis or principal component analysis and the number of factors to extract. Selecting the rotation button helps us choose the type of rotation and the score menu 'Varimax'. The options menu enables the researcher to exclude missing values, sort coefficient displays by size and suppress factor loading in the factor/component matrix that is lower than a chosen value. 


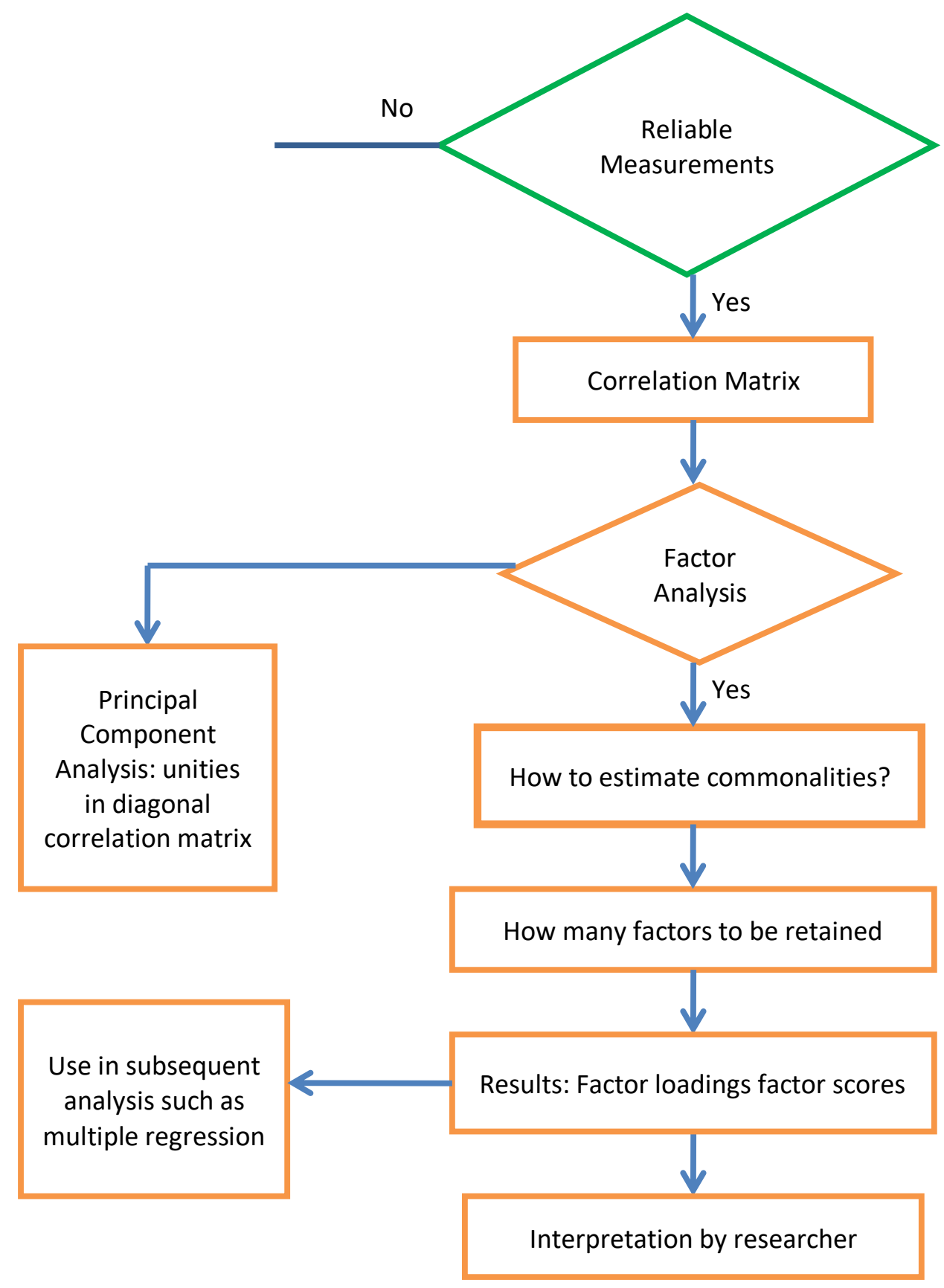

Figure 20: Flow diagram of steps in Factor analysis (Source: Rietveld \& Van Hout 1993: 291) 
Factor analysis for multinational companies

Table 31: Total variances explained for MNCs

\begin{tabular}{|c|c|c|c|c|c|c|c|c|c|}
\hline \multirow[t]{2}{*}{ Components } & \multicolumn{3}{|c|}{ Initial Eigen values } & \multicolumn{3}{|c|}{$\begin{array}{c}\text { Extraction Sums of Squared } \\
\text { Loadings }\end{array}$} & \multicolumn{3}{|c|}{$\begin{array}{c}\text { Rotation Sums of Squared } \\
\text { Loadings }\end{array}$} \\
\hline & Total & $\begin{array}{c}\text { \% of } \\
\text { Variance }\end{array}$ & $\begin{array}{c}\text { Cumulative } \\
\%\end{array}$ & Total & \begin{tabular}{|c|}
$\%$ of \\
Variance
\end{tabular} & $\begin{array}{c}\text { Cumulative } \\
\%\end{array}$ & Total & $\begin{array}{c}\text { \% of } \\
\text { Variance }\end{array}$ & $\begin{array}{c}\text { Cumulative } \\
\%\end{array}$ \\
\hline Specificity & 3.177 & 26.473 & 26.473 & 3.177 & 26.473 & 26.473 & 2.000 & 16.670 & 16.670 \\
\hline Centrality & 2.589 & 21.575 & 48.049 & 2.589 & 21.575 & 48.049 & 1.618 & 13.482 & 30.153 \\
\hline Proactivity & 2.021 & 16.842 & 64.891 & 2.021 & 16.842 & 64.891 & 1.532 & 12.763 & 42.916 \\
\hline Visibility & 1.498 & 12.481 & 77.372 & 1.498 & 12.481 & 77.372 & 1.473 & 12.277 & 55.193 \\
\hline Voluntarism & .973 & 8.109 & 85.481 & .973 & 8.109 & 85.481 & 1.216 & 10.131 & 65.324 \\
\hline Economic responsibility & .768 & 6.400 & 91.881 & .768 & 6.400 & 91.881 & 1.209 & 10.078 & 75.401 \\
\hline Legal responsibility & .527 & 4.389 & 96.270 & .527 & 4.389 & 96.270 & 1.083 & 9.024 & 84.425 \\
\hline Ethical responsibility & .327 & 2.727 & 98.997 & .327 & 2.727 & 98.997 & .949 & 7.906 & 92.332 \\
\hline Philanthropy & .104 & .867 & 99.864 & .104 & .867 & 99.864 & .891 & 7.426 & 99.758 \\
\hline Charity Principle & .011 & .092 & 99.956 & .011 & .092 & 99.956 & .019 & .157 & 99.915 \\
\hline Stewardship & .004 & .036 & 99.993 & .004 & .036 & 99.993 & .005 & .046 & 99.961 \\
\hline Environmental friendliness & .001 & .007 & 100.000 & .001 & .007 & 100.000 & .005 & .039 & 100.000 \\
\hline
\end{tabular}

Extraction Method: Principal Component Analysis.

Among MNCs, specificity has the highest Eigen value and account for $26.473 \%$ of the variance, followed by centrality accounting for $21.575 \%$ of variance, proactivity with $16.842 \%$ of variance, visibility with $12.481 \%$ variance. Remaining factors are not significant. The values given in 'Rotation Sums of Squared Loading' represent distribution of variance after Varimax rotation. After Varimax rotation, all the above four dimensions of CSR amount to $55.193 \%$ of the total variance. 
Table 32: Component matrices for MNCs

\begin{tabular}{|c|c|c|c|c|c|c|c|c|c|c|c|c|}
\hline \multirow[t]{2}{*}{ Variables } & \multicolumn{12}{|c|}{ Component } \\
\hline & 1 & 2 & 3 & 4 & 5 & 6 & 7 & 8 & 9 & 10 & 11 & 12 \\
\hline Specificity & .160 & .082 & .757 & -.475 & .321 & -.167 & .156 & .092 & .052 & .047 & .020 & -.004 \\
\hline Centrality & .875 & -.074 & .297 & -.123 & -.157 & -.233 & -.107 & -.106 & .153 & -.003 & -.032 & .009 \\
\hline Proactivity & .321 & .758 & .295 & -.073 & .190 & .061 & -.296 & .301 & -.106 & -.021 & -.017 & .000 \\
\hline Visibility & .121 & .700 & -.516 & .245 & .118 & -.350 & -.035 & .068 & .158 & -.022 & .024 & -.005 \\
\hline Voluntarism & -.471 & .699 & -.307 & .110 & .371 & .140 & .129 & -.078 & .028 & .043 & -.018 & .014 \\
\hline Economic responsibility & .595 & .089 & .216 & .538 & .118 & -.233 & .470 & -.003 & -.112 & -.019 & -.005 & .001 \\
\hline Legal responsibility & -.380 & .303 & .573 & .522 & -.197 & .319 & .081 & .017 & .121 & .004 & -.016 & -.013 \\
\hline Ethical responsibility & -.282 & -.547 & .460 & .542 & .259 & .039 & -.180 & .107 & .055 & -.016 & .020 & .015 \\
\hline Philanthropy & .659 & -.341 & -.399 & .475 & -.094 & -.001 & -.135 & .183 & -.018 & .068 & -.001 & -.004 \\
\hline Charity principle & .737 & .117 & .060 & .148 & .421 & .290 & -.196 & -.341 & -.025 & -.003 & .012 & -.006 \\
\hline Stewardship & .699 & .095 & -.196 & -.239 & -.154 & .543 & .240 & .161 & .070 & -.015 & .017 & .007 \\
\hline Environmental friendliness & .047 & .697 & .353 & .135 & -.574 & -.063 & -.104 & -.138 & -.072 & .021 & .026 & .008 \\
\hline
\end{tabular}

Extraction Method: Principal Component Analysis.
a. Types of organization = MNC
b. 12 components extracted.

The above table contains unrotated factor loading for MNCs. The values shown above ranging from -1 to +1 represents correlations between variable and factor. All loadings less than 0.4 may be neglected as these values are not important for interpretation. Since average communalities is $11.72 / 19=0.61$ and the variables are less than 30 , we may retain all factors with Eigen value greater than 1 . 
Table 33: Rotated component matrices for MNCs

\begin{tabular}{|c|c|c|c|c|c|c|c|c|c|c|c|c|}
\hline \multirow[t]{2}{*}{ Variables } & \multicolumn{12}{|c|}{ Component (Factor) } \\
\hline & 1 & 2 & 3 & 4 & 5 & 6 & 7 & 8 & 9 & 10 & 11 & 12 \\
\hline Specificity & .206 & -.016 & .936 & .048 & .107 & .062 & -.003 & .221 & -.112 & .041 & .002 & .001 \\
\hline Centrality & .819 & .097 & .181 & -.173 & .255 & .373 & .174 & .087 & .108 & .013 & .056 & .021 \\
\hline Proactivity & -.062 & .314 & .257 & -.077 & .040 & .248 & .133 & .834 & .221 & .002 & .001 & .001 \\
\hline Visibility & -.281 & .100 & -.265 & -.341 & .203 & .046 & -.080 & .272 & .775 & .002 & -.001 & -.001 \\
\hline Voluntarism & -.905 & .116 & .018 & -.109 & -.055 & .053 & -.063 & .127 & .357 & .009 & .040 & .018 \\
\hline Economic responsibility & .170 & .092 & .006 & .085 & .946 & .204 & .079 & .032 & .104 & .000 & .001 & .001 \\
\hline Legal responsibility & -.305 & .689 & .089 & .631 & .094 & -.087 & .023 & .010 & -.064 & -.019 & .024 & .058 \\
\hline Ethical responsibility & .081 & -.151 & -.021 & .891 & .084 & .011 & -.339 & -.077 & -.218 & .007 & -.009 & -.017 \\
\hline Philanthropy & .456 & -.270 & -.685 & .079 & .348 & .204 & .219 & .066 & .110 & .129 & .002 & -.002 \\
\hline Charity Principle & .133 & -.067 & -.020 & -.007 & .217 & .924 & .207 & .180 & .028 & .003 & -.001 & -.001 \\
\hline Stewardship & .172 & -.035 & -.080 & -.271 & .101 & .233 & .900 & .100 & -.062 & .003 & .001 & .000 \\
\hline Environmental friendliness & .051 & .949 & .035 & -.164 & .056 & -.027 & -.037 & .229 & .103 & .002 & -.006 & -.017 \\
\hline
\end{tabular}

Extraction Method: Principal Component Analysis.

Rotation Method: Varimax with Kaiser Normalization. a. Types of organization = MNC b. Rotation converged in 21 iterations.

The goal of rotation is to attain an optimal simple structure which attempts to have each variable load on as few factors as possible, but maximizes the number of high loadings on each variable (Rummel 1970). The columns show factors that are extracted after rotation. From table above, among the MNCs, it may be noted that centrality and voluntarism are loaded on Factor 1, legal responsibility and environmental friendliness are loaded on Factor 2, specificity and philanthropy are loaded on Factor 3, legal responsibility and ethical responsibility are loaded on Factor 4, economic responsibility on Factor 5, charity principle on Factor 6, stewardship on Factor 7, proactivity on Factor 8, and visibility on Factor 9. 
Table 34: Component transformation matrices for MNCs

\begin{tabular}{|c|c|c|c|c|c|c|c|c|c|c|c|c|}
\hline Components & 1 & 2 & 3 & 4 & 5 & 6 & 7 & 8 & 9 & 10 & 11 & 12 \\
\hline Specificity & .578 & -.073 & -.061 & -.236 & .400 & .480 & .401 & .204 & .086 & .034 & .008 & -.003 \\
\hline Centrality & -.437 & .550 & .144 & -.314 & .056 & .101 & .076 & .440 & .418 & -.015 & .012 & .010 \\
\hline Proactivity & .254 & .403 & .649 & .458 & .124 & .054 & -.119 & .140 & -.300 & -.013 & .007 & .011 \\
\hline Visibility & -.123 & .225 & -.544 & .565 & .496 & .112 & -.181 & -.034 & .162 & .024 & .002 & .011 \\
\hline Voluntarism & -.395 & -.628 & .331 & .194 & .135 & .439 & -.174 & .206 & .137 & .008 & .003 & -.003 \\
\hline Economic responsibility & -.342 & .098 & -.146 & .272 & -.295 & .301 & .669 & .002 & -.390 & -.017 & .000 & .021 \\
\hline Legal responsibility & -.295 & -.049 & .283 & -.153 & .626 & -.307 & .353 & -.436 & -.072 & -.028 & .007 & .020 \\
\hline Ethical responsibility & .080 & -.267 & -.038 & .264 & .058 & -.605 & .318 & .604 & .095 & .078 & -.023 & -.006 \\
\hline Philanthropy & .166 & .008 & .206 & .330 & -.271 & .007 & .283 & -.372 & .710 & .002 & .118 & .104 \\
\hline Charity principle & -.040 & .033 & .023 & -.035 & -.010 & .019 & -.021 & -.045 & -.042 & .978 & .172 & .067 \\
\hline Stewardship & .005 & .029 & .047 & .047 & -.031 & .022 & .051 & -.080 & .103 & .175 & -.744 & -.624 \\
\hline Environmental friendliness & -.007 & .002 & -.002 & .015 & .002 & -.010 & .016 & .001 & -.002 & -.058 & .634 & -.771 \\
\hline
\end{tabular}

Extraction Method: Principal Component Analysis. Rotation Method: Varimax with Kaiser Normalization.

a. Types of organization $=$ MNC

The above table gives optimal rotation of various components among the MNC category. The component transformation enables different view of data. 
Factor analysis for Indian private companies:

Table 35: Total variances explained for Indian private companies

\begin{tabular}{|c|c|c|c|c|c|c|c|c|c|}
\hline \multirow[t]{2}{*}{ Components } & \multicolumn{3}{|c|}{ Initial Eigen values } & \multicolumn{3}{|c|}{$\begin{array}{c}\text { Extraction Sums of Squared } \\
\text { Loadings }\end{array}$} & \multicolumn{3}{|c|}{$\begin{array}{c}\text { Rotation Sums of Squared } \\
\text { Loadings }\end{array}$} \\
\hline & Total & $\begin{array}{c}\% \text { of } \\
\text { Variance }\end{array}$ & $\begin{array}{c}\text { Cumulative } \\
\%\end{array}$ & Total & $\begin{array}{c}\% \text { of } \\
\text { Variance }\end{array}$ & $\begin{array}{c}\text { Cumulative } \\
\%\end{array}$ & Total & $\begin{array}{c}\% \text { of } \\
\text { Variance }\end{array}$ & $\begin{array}{c}\text { Cumulative } \\
\%\end{array}$ \\
\hline Specificity & 5.513 & 45.943 & 45.943 & 5.513 & 45.943 & 45.943 & 2.299 & 19.158 & 19.158 \\
\hline Centrality & 2.032 & 16.931 & 62.874 & 2.032 & 16.931 & 62.874 & 1.880 & 15.670 & 34.828 \\
\hline Proactivity & 1.443 & 12.026 & 74.899 & 1.443 & 12.026 & 74.899 & 1.450 & 12.081 & 46.909 \\
\hline Visibility & 1.246 & 10.384 & 85.283 & 1.246 & 10.384 & 85.283 & 1.410 & 11.748 & 58.658 \\
\hline Voluntarism & .705 & 5.879 & 91.162 & .705 & 5.879 & 91.162 & 1.236 & 10.301 & 68.959 \\
\hline Economic responsibility & .506 & 4.215 & 95.377 & .506 & 4.215 & 95.377 & 1.232 & 10.263 & 79.222 \\
\hline Legal responsibility & .260 & 2.170 & 97.547 & .260 & 2.170 & 97.547 & 1.182 & 9.846 & 89.069 \\
\hline Ethical responsibility & .173 & 1.443 & 98.990 & .173 & 1.443 & 98.990 & 1.130 & 9.419 & 98.488 \\
\hline Philanthropy & .096 & .797 & 99.787 & .096 & .797 & 99.787 & .093 & .773 & 99.261 \\
\hline Charity principle & .023 & .188 & 99.975 & .023 & .188 & 99.975 & .084 & .699 & 99.960 \\
\hline Stewardship & .002 & .020 & 99.995 & .002 & .020 & 99.995 & .004 & .034 & 99.994 \\
\hline Environmental friendliness & .001 & .005 & 100.000 & .001 & .005 & 100.000 & .001 & .006 & 100.000 \\
\hline
\end{tabular}

Extraction Method: Principal Component Analysis.

It is observed that among Indian private companies, specificity has highest Eigen value and account for $45.943 \%$ of variance followed by centrality with $16.931 \%$ variance, proactivity with $12.026 \%$ variance and visibility with $10.384 \%$ variance. Remaining factors are not significant. After Varimax rotation, all the above four dimensions of CSR account for $58.658 \%$ of the total variance. 
Table 36: Component matrices for Indian private companies

\begin{tabular}{|c|c|c|c|c|c|c|c|c|c|c|c|c|}
\hline \multirow[t]{2}{*}{ Variables } & \multicolumn{12}{|c|}{ Component } \\
\hline & 1 & 2 & 3 & 4 & 5 & 6 & 7 & 8 & 9 & 10 & 11 & 12 \\
\hline Specificity & .288 & .724 & .322 & -.241 & .316 & .339 & -.049 & -.105 & .022 & .047 & -.007 & .005 \\
\hline Centrality & .644 & .532 & .003 & -.041 & .181 & -.450 & .239 & -.071 & -.051 & .024 & .007 & -.003 \\
\hline Proactivity & .387 & .745 & -.123 & .275 & -.372 & .157 & .169 & .097 & -.002 & -.058 & -.009 & .004 \\
\hline Visibility & .471 & .096 & -.278 & .744 & .319 & .147 & -.041 & .103 & .046 & .024 & .009 & -.008 \\
\hline Voluntarism & .838 & -.193 & .191 & -.340 & .251 & -.013 & .057 & .062 & .183 & -.076 & .003 & -.001 \\
\hline Economic responsibility & .539 & .185 & .689 & .132 & -.357 & -.127 & -.169 & .074 & .057 & .035 & .019 & .001 \\
\hline Legal responsibility & .804 & -.216 & .448 & .063 & .199 & .001 & -.085 & .108 & -.204 & -.038 & -.013 & -.001 \\
\hline Ethical responsibility & .580 & -.648 & .250 & .017 & -.151 & .230 & .318 & .007 & .005 & .059 & -.004 & -.001 \\
\hline Philanthropy & .898 & -.015 & -.180 & -.090 & -.222 & .179 & -.077 & -.248 & -.055 & -.033 & .012 & -.010 \\
\hline Charity principle & .524 & .140 & -.513 & -.613 & -.068 & .083 & -.047 & .221 & -.052 & .038 & .011 & -.002 \\
\hline Stewardship & .863 & -.311 & -.330 & .188 & .075 & -.037 & -.037 & -.068 & -.015 & .000 & .013 & .018 \\
\hline Environmental friendliness & .918 & -.071 & -.258 & .034 & -.145 & -.180 & -.145 & -.030 & .079 & .036 & -.034 & -.002 \\
\hline
\end{tabular}

Extraction Method: Principal Component Analysis.

a. Types of organization = Indian private $\quad$ b. 12 components extracted.

The above table contains unrotated factor loading among Indian private companies. The values shown above ranging from -1 to +1 represents correlations between variable and factor. Values less than 0.4 are not important for interpretation, and therefore may be neglected. Average communalities is $10.961 / 16=0.6185$ which is fairly good, and the variables are less than 30. Therefore, all factors with Eigen value greater than 1 may be retained. 
Table 37: Rotated component matrices for Indian private companies

\begin{tabular}{|c|c|c|c|c|c|c|c|c|c|c|c|c|}
\hline \multirow[t]{2}{*}{ Variables } & \multicolumn{12}{|c|}{ Component (Factor) } \\
\hline & 1 & 2 & 3 & 4 & 5 & 6 & 7 & 8 & 9 & 10 & 11 & 12 \\
\hline Specificity & -.014 & -.063 & .156 & .011 & .943 & .100 & .189 & .189 & .011 & .009 & -.001 & -.001 \\
\hline Centrality & .234 & -.005 & .184 & .138 & .247 & .152 & .871 & .219 & .015 & .011 & .000 & .000 \\
\hline Proactivity & .146 & -.132 & .172 & .206 & .222 & .103 & .193 & .890 & -.011 & -.010 & .000 & .000 \\
\hline Visibility & .210 & .058 & -.006 & .949 & .035 & -.086 & .093 & .184 & .008 & .004 & .001 & -.002 \\
\hline Voluntarism & .370 & .578 & .274 & .088 & .269 & .367 & .322 & -.239 & -.020 & .280 & .001 & .000 \\
\hline Economic responsibility & .155 & .209 & .907 & -.047 & .153 & -.121 & .143 & .221 & -.028 & .018 & .001 & .000 \\
\hline Legal responsibility & .278 & .562 & .554 & .289 & .200 & .085 & .219 & -.198 & .286 & -.019 & -.002 & .000 \\
\hline Ethical responsibility & .282 & .924 & .170 & .042 & -.156 & .000 & -.084 & -.054 & -.020 & -.021 & .001 & .000 \\
\hline Philanthropy & .831 & .335 & .159 & .113 & .156 & .265 & .099 & .225 & .055 & -.016 & -.031 & -.010 \\
\hline Charity principle & .383 & .052 & -.132 & -.090 & .123 & .882 & .138 & .111 & .010 & .006 & -.001 & .000 \\
\hline Stewardship & .694 & .386 & .057 & .492 & -.151 & .231 & .209 & -.049 & .040 & .021 & -.008 & .024 \\
\hline Environmental friendliness & .736 & .210 & .287 & .297 & -.110 & .351 & .298 & .091 & -.066 & .057 & .056 & -.002 \\
\hline
\end{tabular}

Extraction Method: Principal Component Analysis.

Rotation Method: Varimax with Kaiser Normalization.

a. Types of organization = Indian private $b$. Rotation converged in 20 iterations.

From table, it may be noted that among Indian private companies, philanthropy, stewardship and environmental friendliness are loaded on Factor 1, voluntarism, legal responsibility and ethical responsibility are loaded on Factor 2 , economic and legal responsibilities on Factor 3, visibility on Factor 4, specificity on Factor 5, charity principle on Factor

6, centrality on Factor 7 and proactivity on Factor 8. 
Table 38: Component transformation matrices for Indian private companies

\begin{tabular}{|c|c|c|c|c|c|c|c|c|c|c|c|c|}
\hline Components & 1 & 2 & 3 & 4 & 5 & 6 & 7 & 8 & 9 & 10 & 11 & 12 \\
\hline Specificity & .599 & .434 & .340 & .304 & .160 & .301 & .331 & .119 & .041 & .052 & .003 & .002 \\
\hline Centrality & -.132 & -.525 & .081 & .011 & .535 & .066 & .323 & .551 & -.024 & -.018 & -.001 & -.004 \\
\hline Proactivity & -.328 & .311 & .655 & -.260 & .320 & -.415 & .011 & -.138 & .064 & .023 & -.004 & -.004 \\
\hline Visibility & -.037 & -.062 & .120 & .710 & -.267 & -.570 & -.065 & .264 & .012 & -.075 & .004 & .003 \\
\hline Voluntarism & -.234 & .014 & -.308 & .453 & .438 & -.009 & .286 & -.591 & .110 & .099 & -.003 & .006 \\
\hline Economic responsibility & .013 & .317 & -.235 & .137 & .503 & .056 & -.706 & .256 & .035 & -.053 & -.030 & -.006 \\
\hline Legal responsibility & -.310 & .570 & -.438 & -.137 & -.092 & -.134 & .430 & .386 & -.087 & .000 & -.018 & .001 \\
\hline Ethical responsibility & -.599 & .086 & .290 & .289 & -.235 & .612 & -.097 & .108 & .075 & .094 & .037 & .005 \\
\hline Philanthropy & .005 & -.007 & .035 & .057 & .041 & -.038 & -.072 & -.017 & -.763 & .632 & .072 & -.001 \\
\hline Charity principle & -.062 & .043 & .068 & .074 & .063 & .100 & .036 & -.131 & -.605 & -.753 & .133 & .009 \\
\hline Stewardship & -.020 & -.011 & .037 & .026 & -.014 & .034 & .008 & -.026 & -.133 & -.050 & -.982 & .102 \\
\hline Environmental friendliness & .005 & .000 & -.003 & -.010 & .007 & -.007 & -.006 & .008 & .018 & .011 & .099 & .995 \\
\hline
\end{tabular}

Extraction Method: Principal Component Analysis.

Rotation Method: Varimax with Kaiser Normalization.

a. Types of organization = Indian Private

The above table depicts an optimal rotation of various components among the Indian private companies. The component transformation maximizes scatter along the first dimension ( $\mathrm{x}$-axis), and next maximum in the second dimension and so on. The transformation enables different view of data. 
Factor analysis for public sector enterprises

Table 39: Total variances explained for PSEs

\begin{tabular}{|c|c|c|c|c|c|c|c|c|c|}
\hline \multirow[t]{2}{*}{ Components } & \multicolumn{3}{|c|}{ Initial Eigen values } & \multicolumn{3}{|c|}{$\begin{array}{c}\text { Extraction Sums of Squared } \\
\text { Loadings }\end{array}$} & \multicolumn{3}{|c|}{$\begin{array}{c}\text { Rotation Sums of Squared } \\
\text { Loadings }\end{array}$} \\
\hline & Total & $\begin{array}{c}\% \text { of } \\
\text { Variance }\end{array}$ & $\begin{array}{c}\text { Cumulative } \\
\%\end{array}$ & Total & $\begin{array}{c}\% \text { of } \\
\text { Variance }\end{array}$ & $\begin{array}{c}\text { Cumulative } \\
\%\end{array}$ & Total & $\begin{array}{c}\% \text { of } \\
\text { Variance }\end{array}$ & $\begin{array}{c}\text { Cumulative } \\
\%\end{array}$ \\
\hline Specificity & 4.177 & 34.807 & 34.807 & 4.177 & 34.807 & 34.807 & 2.580 & 21.503 & 21.503 \\
\hline Centrality & 1.735 & 14.460 & 49.267 & 1.735 & 14.460 & 49.267 & 1.246 & 10.381 & 31.885 \\
\hline Proactivity & 1.577 & 13.142 & 62.410 & 1.577 & 13.142 & 62.410 & 1.146 & 9.550 & 41.435 \\
\hline Visibility & 1.420 & 11.835 & 74.245 & 1.420 & 11.835 & 74.245 & 1.135 & 9.455 & 50.890 \\
\hline Voluntarism & 1.073 & 8.941 & 83.187 & 1.073 & 8.941 & 83.187 & 1.134 & 9.451 & 60.341 \\
\hline Economic responsibility & .798 & 6.647 & 89.834 & .798 & 6.647 & 89.834 & 1.116 & 9.300 & 69.641 \\
\hline Legal responsibility & .464 & 3.868 & 93.702 & .464 & 3.868 & 93.702 & 1.109 & 9.239 & 78.880 \\
\hline Ethical responsibility & .407 & 3.394 & 97.095 & .407 & 3.394 & 97.095 & 1.057 & 8.804 & 87.685 \\
\hline Philanthropy & .173 & 1.444 & 98.539 & .173 & 1.444 & 98.539 & .739 & 6.162 & 93.847 \\
\hline Charity principle & .103 & .861 & 99.400 & .103 & .861 & 99.400 & .629 & 5.245 & 99.092 \\
\hline Stewardship & .057 & .479 & 99.879 & .057 & .479 & 99.879 & .077 & .644 & 99.736 \\
\hline Environmental friendliness & .015 & .121 & 100.000 & .015 & .121 & 100.000 & .032 & .264 & 100.000 \\
\hline
\end{tabular}

Extraction Method: Principal Component Analysis.

In the case of PSEs, it is observed that specificity has highest Eigen value and account for $34.807 \%$ of variance, followed by centrality with $14.460 \%$ variance, proactivity with $13.142 \%$ variance, and visibility with $11.835 \%$ variance. Remaining factors are not significant. After Varimax rotation, all the above four dimensions of CSR account for $50.89 \%$ of the total variance. 
Table 40: Component matrices for PSES

\begin{tabular}{|l|r|r|r|r|r|r|r|r|r|r|r|r|}
\hline \multirow{2}{*}{ Variables } & \multicolumn{10}{|c|}{ Component (Factor) } \\
\cline { 2 - 12 } & \multicolumn{1}{|c|}{1} & \multicolumn{1}{|c|}{2} & \multicolumn{1}{c|}{3} & \multicolumn{1}{c|}{4} & \multicolumn{1}{c|}{5} & \multicolumn{1}{c|}{6} & \multicolumn{1}{c|}{7} & \multicolumn{1}{c|}{8} & 9 & 10 & 11 & 12 \\
\hline Specificity & .818 & .205 & .019 & .008 & -.268 & -.219 & .161 & .328 & .141 & .059 & -.103 & .022 \\
\hline Centrality & .510 & .039 & .648 & .095 & -.067 & .176 & -.504 & .137 & .002 & -.043 & .008 & .013 \\
\hline Proactivity & .623 & .243 & .236 & -.569 & .299 & .125 & .159 & .017 & -.128 & -.140 & -.071 & -.034 \\
\hline Visibility & -.124 & .769 & -.159 & -.228 & .256 & .464 & .024 & .121 & .053 & .114 & .064 & .018 \\
\hline Voluntarism & .078 & -.475 & -.182 & .607 & .086 & .542 & .129 & .209 & -.049 & -.028 & -.043 & -.015 \\
\hline Economic responsibility & .520 & -.523 & -.161 & -.487 & -.198 & .275 & .003 & -.105 & .252 & -.039 & .049 & -.014 \\
\hline Legal responsibility & .174 & -.539 & .400 & -.097 & .673 & -.160 & .036 & .061 & .040 & .155 & .010 & -.010 \\
\hline Ethical responsibility & .017 & .141 & .836 & .297 & -.148 & .103 & .358 & -.153 & .057 & -.032 & .057 & .021 \\
\hline Philanthropy & .895 & -.233 & -.280 & -.032 & .162 & .025 & .029 & -.122 & -.117 & -.023 & .023 & .091 \\
\hline Charity principle & .434 & .383 & -.238 & .525 & .489 & -.142 & -.070 & -.144 & .190 & -.108 & -.009 & -.012 \\
\hline Stewardship & .908 & .065 & -.151 & .156 & -.117 & -.198 & .062 & .176 & -.097 & .000 & .160 & -.042 \\
\hline Environmental friendliness & .850 & .163 & -.008 & .175 & -.201 & .150 & -.055 & -.343 & -.064 & .162 & -.063 & -.034 \\
\hline
\end{tabular}

Extraction Method: Principal Component Analysis.
a. Types of organization $=$ PSES
b. 12 components extracted.

The table contains unrotated factor loading for PSEs. The values ranging from -1 to +1 represents correlations between variable and factor. Values less than 0.4 are not important for interpretation, and therefore may be rejected. Average communalities is $11.509 / 18=0.639$ which is fairly good, and the variables are less than 30 . Therefore, all factors with Eigen value greater than 1 may be retained. 
Table 41: Rotated Component matrices for PSES

\begin{tabular}{|c|c|c|c|c|c|c|c|c|c|c|c|c|}
\hline \multirow[t]{2}{*}{ Variables } & \multicolumn{12}{|c|}{ Component } \\
\hline & 1 & 2 & 3 & 4 & 5 & 6 & 7 & 8 & 9 & 10 & 11 & 12 \\
\hline Specificity & .951 & .126 & -.055 & .006 & .080 & -.091 & .079 & .149 & .036 & .063 & -.162 & -.035 \\
\hline Centrality & .224 & .054 & .121 & -.019 & .021 & .000 & .226 & .930 & .104 & .072 & .002 & .001 \\
\hline Proactivity & .355 & .274 & .284 & .359 & .011 & -.276 & .079 & .165 & .121 & .682 & .000 & -.002 \\
\hline Visibility & -.090 & -.109 & -.191 & .953 & .109 & -.091 & -.047 & -.025 & -.017 & .106 & -.005 & -.003 \\
\hline Voluntarism & -.007 & .065 & .051 & -.087 & .074 & .986 & .011 & .003 & .031 & -.082 & .005 & .004 \\
\hline Economic responsibility & .214 & .912 & .095 & -.110 & -.198 & .071 & -.165 & .056 & .120 & .114 & -.002 & -.004 \\
\hline Legal responsibility & -.050 & .086 & .962 & -.178 & .052 & .055 & .051 & .106 & -.043 & .105 & .003 & .004 \\
\hline Ethical responsibility & .001 & -.143 & .053 & -.044 & -.045 & .012 & .964 & .205 & .033 & .025 & -.005 & -.004 \\
\hline Philanthropy & .557 & .410 & .210 & -.125 & .285 & .172 & -.241 & .040 & .406 & .300 & .091 & .170 \\
\hline Charity principle & .264 & -.175 & .059 & .125 & .924 & .086 & -.052 & .020 & .128 & .010 & .004 & .003 \\
\hline Stewardship & .889 & .110 & -.003 & -.109 & .233 & .064 & -.080 & .134 & .213 & .119 & .207 & .033 \\
\hline Environmental friendliness & .522 & .256 & -.153 & .001 & .277 & .043 & .131 & .257 & .684 & .095 & -.007 & -.019 \\
\hline
\end{tabular}

Extraction Method: Principal Component Analysis.

Rotation Method: Varimax with Kaiser Normalization. a. Types of organization = PSEs

b. Rotation converged in 10 iterations.

From table, it may be noted that in the case of PSEs, specificity, philanthropy, stewardship and environmental friendliness are loaded on Factor 1, economic responsibility on Factor 2, legal responsibility on Factor 3, visibility on Factor 4, charity principle on Factor 5 , voluntarism on Factor 6 , ethical responsibility on Factor 7, centrality on Factor 8 , environmental friendliness on Factor 9, and proactivity on Factor 10. 
Table 42: Component transformation matrices for PSEs

\begin{tabular}{|c|c|c|c|c|c|c|c|c|c|c|c|c|}
\hline Components & 1 & 2 & 3 & 4 & 5 & 6 & 7 & 8 & 9 & 10 & 11 & 12 \\
\hline Specificity & .740 & .339 & .124 & -.036 & .259 & .042 & -.006 & .272 & .338 & .247 & .032 & .033 \\
\hline Centrality & .146 & -.390 & -.416 & .622 & .280 & -.395 & .144 & .045 & .033 & .084 & -.027 & -.030 \\
\hline Proactivity & -.094 & -.138 & .322 & -.083 & -.213 & -.184 & .707 & .516 & -.062 & .093 & -.040 & -.035 \\
\hline Visibility & .067 & -.439 & -.143 & -.258 & .461 & .561 & .245 & .071 & .089 & -.339 & .023 & .002 \\
\hline Voluntarism & -.236 & -.152 & .710 & .285 & .476 & .073 & -.169 & -.075 & -.069 & .249 & .037 & .038 \\
\hline Economic responsibility & -.280 & .344 & -.175 & .538 & -.146 & .597 & .124 & .215 & .164 & .129 & -.007 & .000 \\
\hline Legal responsibility & .252 & .031 & .089 & .082 & -.121 & .159 & .523 & -.746 & -.075 & .209 & -.027 & .001 \\
\hline Ethical responsibility & .447 & -.264 & .123 & .216 & -.327 & .287 & -.231 & .180 & -.621 & -.052 & -.060 & -.046 \\
\hline Philanthropy & .011 & .521 & .033 & .123 & .368 & -.130 & .184 & -.002 & -.405 & -.491 & -.310 & -.159 \\
\hline Charity principle & .135 & -.136 & .355 & .286 & -.302 & -.053 & -.055 & -.102 & .518 & -.597 & -.128 & -.083 \\
\hline Stewardship & .043 & .137 & .043 & .127 & .013 & -.070 & .102 & -.003 & -.132 & -.282 & .892 & .232 \\
\hline Environmental friendliness & .009 & .007 & -.002 & .031 & -.012 & -.020 & .026 & .015 & -.030 & -.080 & -.288 & .953 \\
\hline
\end{tabular}

Extraction Method: Principal Component Analysis.

Rotation Method: Varimax with Kaiser Normalization.

a. Types of organization $=$ PSES

The above table depicts an optimal rotation of various components among the PSEs. The component transformation enables different view of data through maximizing scatter along the first dimension ( $\mathrm{x}$-axis), and next maximum in the second dimension and so on. 


\subsection{Regression model 2 (R2)}

\section{A. MULTINATIONAL COMPANIES}

On examining the output of second regression, the F-value 13.927 is significant ( $p$ value $=0.00$ ). The R-square is 0.908 which means $90.8 \%$ of variability in value creation is accounted for by the variables in the model. The adjusted R-square shows that $84.2 \%$ of variability in value creation is accounted for by the model, after taking into account the number of predictor variables. The Durbin Watson statistic 1.602 is a good indicator that the residuals are independent (Annexure VI).

The graphs are plotted for normality, linearity, to detect heteroscedasticity, autocorrelation and multicollinearity as shown in figures 21, 22,23 and 24 below:

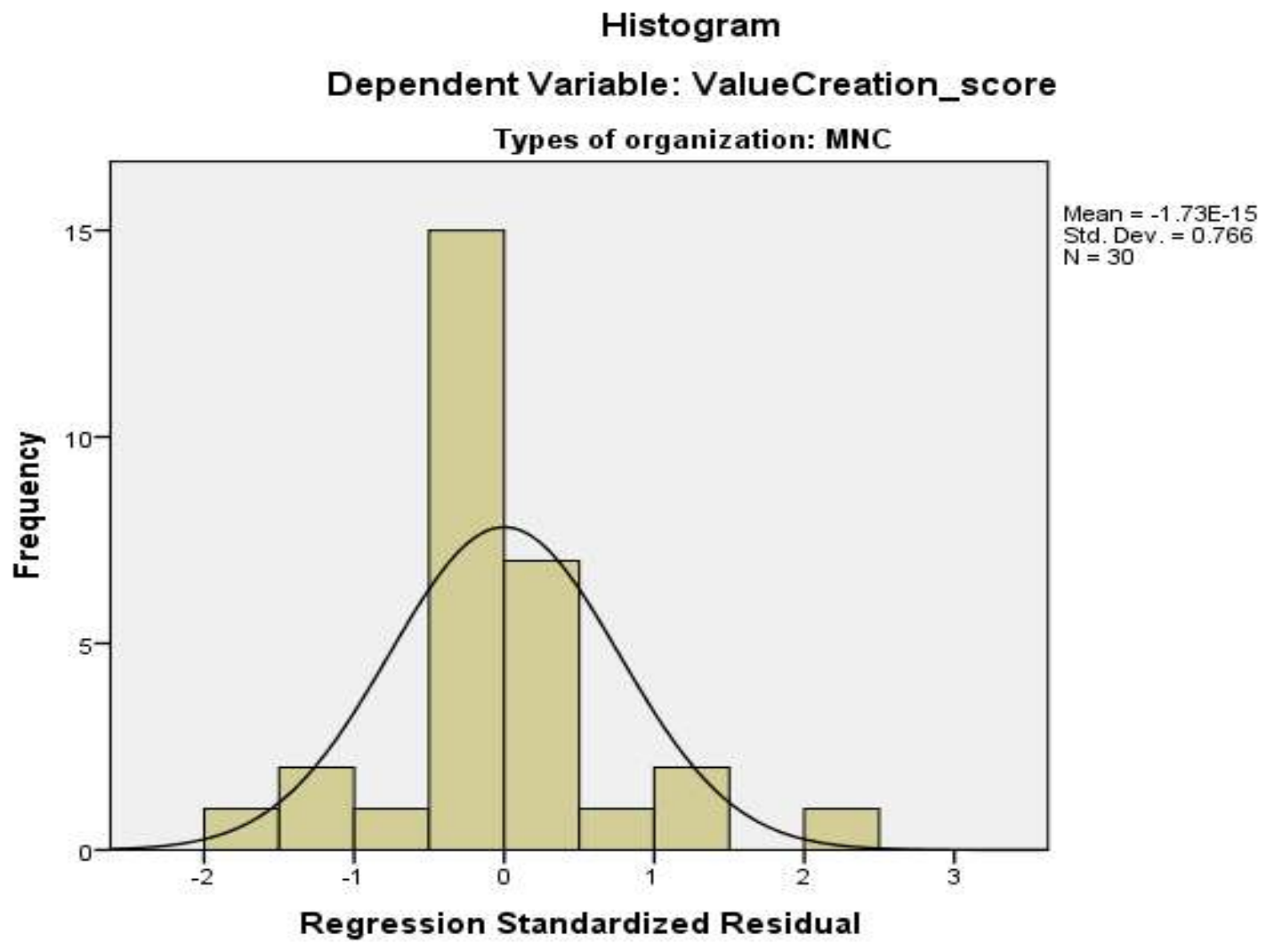

Figure 21: Test of normality for MNCs under R2 (Histogram on ZRESID versus Frequency) 


\section{Normal P-P Plot of Regression Standardized Residual} Dependent Variable: ValueCreation_score

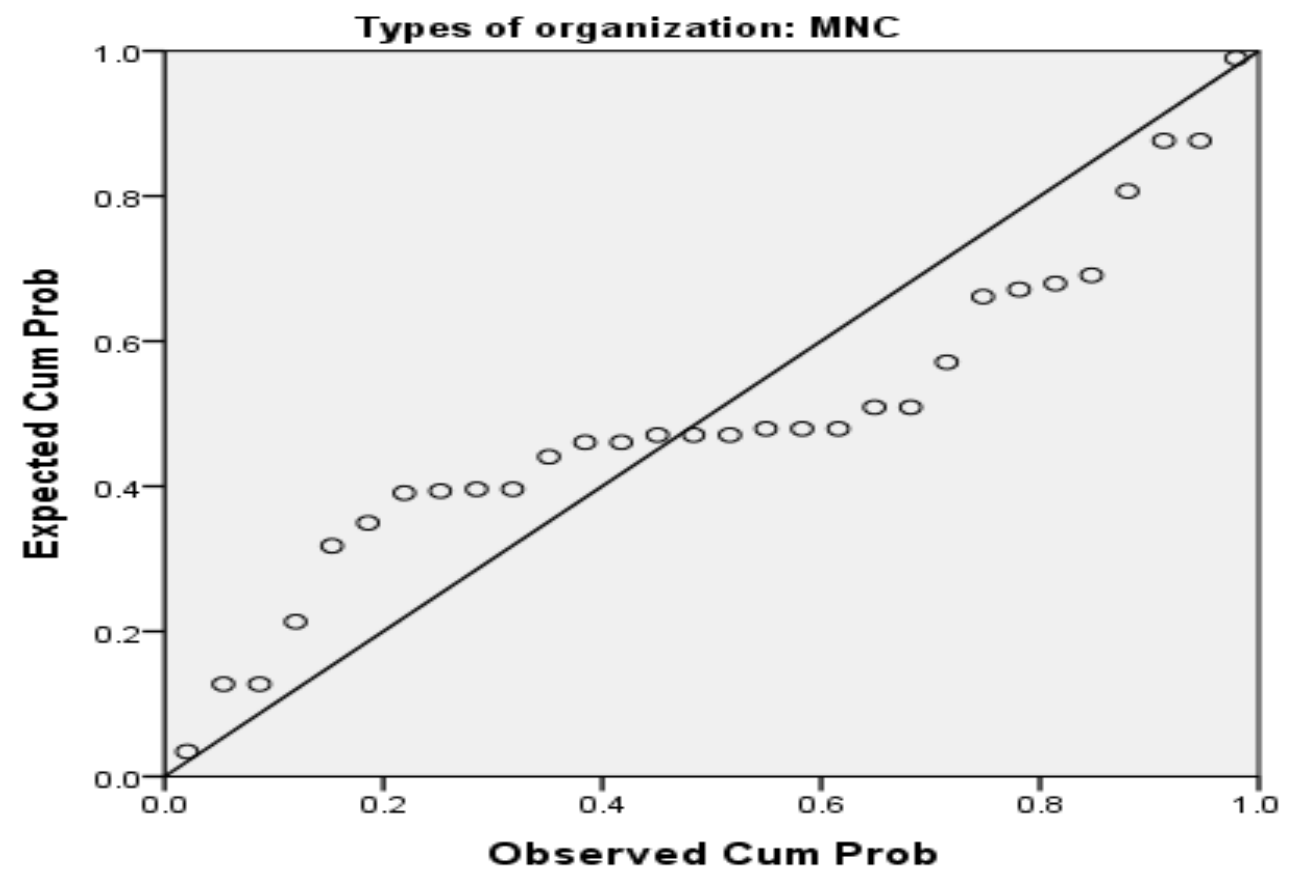

Figure 22: Test of normality for MNCs under R2 (Normal plot of ZRESID)

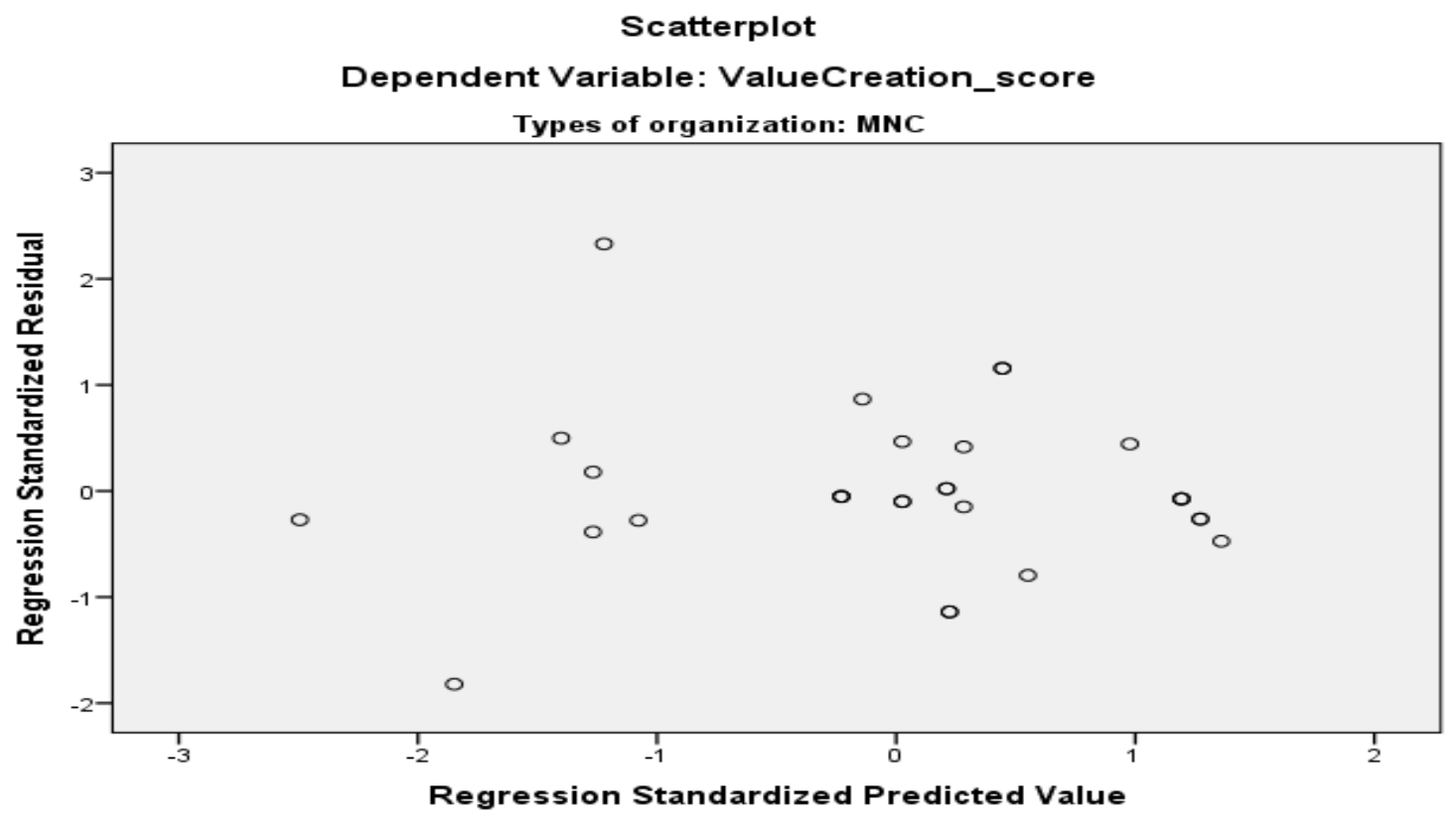

Figure 23: Test of heteroscedasticity for MNCs under R2 (ZPRED and ZRESID) 
On analyzing the above plotted graph of ZPRED on $x$-axis and ZRESID on $y$-axis, it may be suggested that there is no pattern observed. Therefore, it may be inferred that the graph does not suffer from heteroscedasticity.

In order to understand the relationship between response variable and explanatory variables, we plot value creation with ZPRED as below.

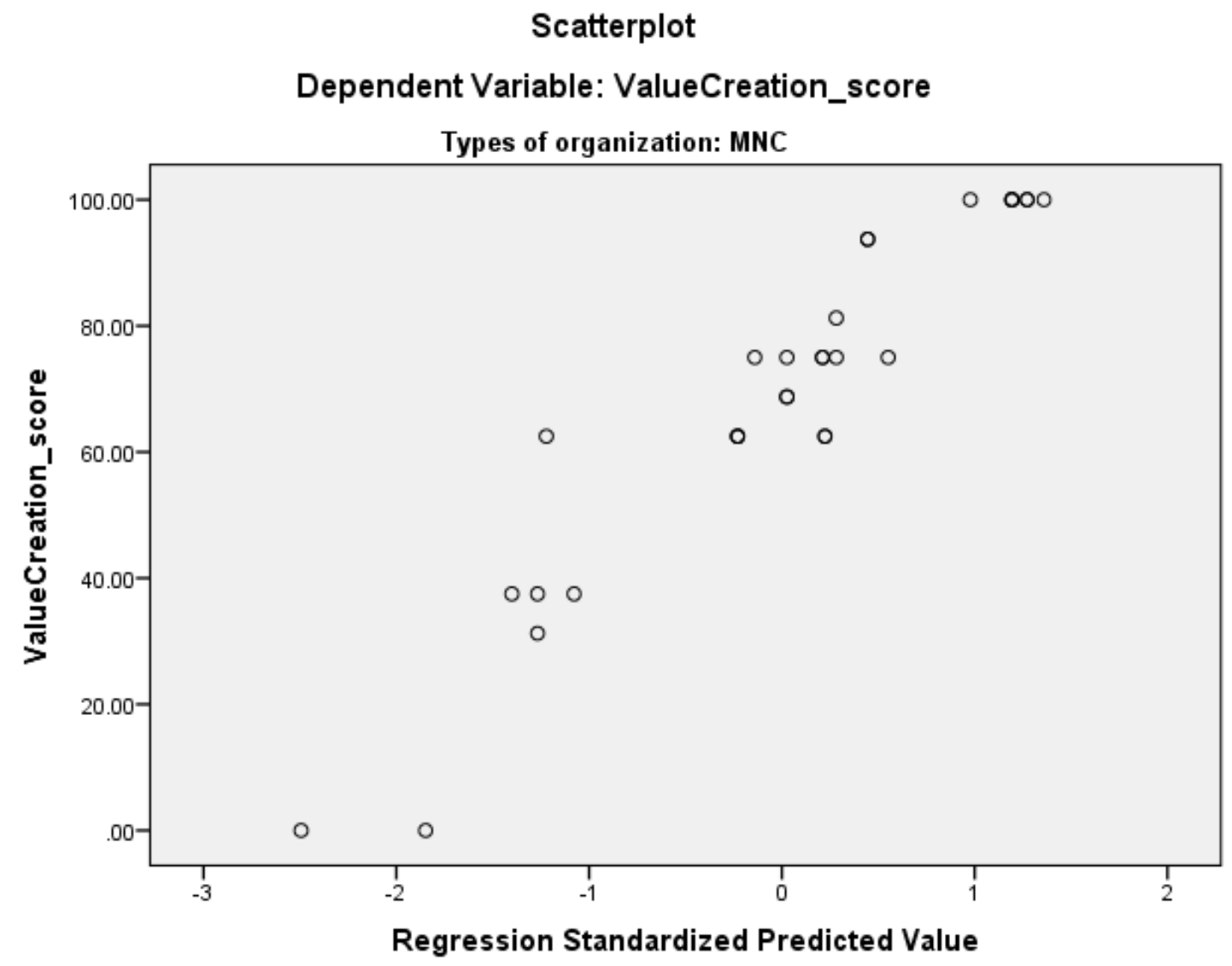

Figure 24: Test of linearity for MNCs under R2 (ZPRED versus Value creation)

The above graph in figure 24 suggests that the plot is linear 
Table 43: Test for multicollinearity for MNCs under Regression 2

\begin{tabular}{|l|r|r|r|r|}
\hline Dimensions & \multicolumn{1}{|l|}{ VIF } & \multicolumn{2}{l|}{ Eigen value } & \multicolumn{1}{l|}{ Condition Index } \\
\hline Constant & & & 1.000 & 1.000 \\
\hline Specificity & 1.000 & 1.000 & 1.000 & 1.000 \\
\hline Centrality & 1.000 & 1.000 & 1.000 & 1.000 \\
\hline Proactivity & 1.000 & 1.000 & 1.000 & 1.000 \\
\hline Visibility & 1.000 & 1.000 & 1.000 & 1.000 \\
\hline Voluntarism & 1.000 & 1.000 & 1.000 & 1.000 \\
\hline Economic responsibility & 1.000 & 1.000 & 1.000 & 1.000 \\
\hline Legal responsibility & 1.000 & 1.000 & 1.000 & 1.000 \\
\hline Ethical responsibility & 1.000 & 1.000 & 1.000 & 1.000 \\
\hline Philanthropy & 1.000 & 1.000 & 1.000 & 1.000 \\
\hline Charity principle & 1.000 & 1.000 & 1.000 & 1.000 \\
\hline Stewardship & 1.000 & 1.000 & 1.000 & 1.000 \\
\hline Environmental friendliness & 1.000 & 1.000 & 1.000 & 1.000 \\
\hline
\end{tabular}

The tolerance is 1 and the VIF is also 1 for all variables, as shown in the table above.

The model depicted above does not suffer from multicollinearity as observed in the above table . 
Table 44: Regression 2 outcomes among multinational companies (MNCs)

\begin{tabular}{|c|c|c|c|c|c|c|c|c|c|}
\hline 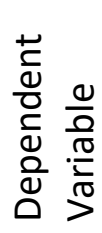 & 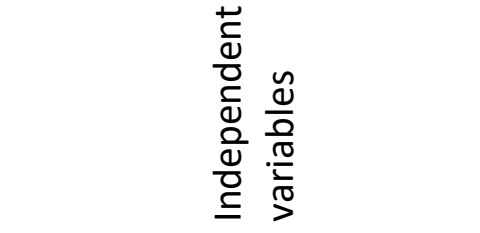 & $\begin{array}{l}\pi \\
\stackrel{D}{D}\end{array}$ & 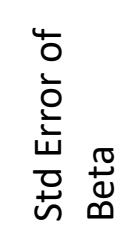 & 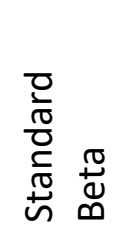 & + & $\begin{array}{l}\frac{0}{2} \\
\frac{2}{2} \\
\frac{1}{2}\end{array}$ & $\begin{array}{l}\frac{0}{0} \\
\frac{0}{0} \\
0 \\
0 \\
\simeq\end{array}$ & 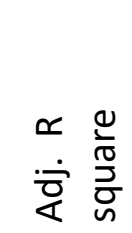 & $\frac{\frac{0}{3}}{\frac{\pi}{2}}$ \\
\hline \multirow{13}{*}{$\begin{array}{l}\frac{.}{0} \\
\frac{0}{0} \\
\frac{0}{U} \\
\frac{0}{0} \\
\frac{0}{\pi} \\
\frac{J}{J}\end{array}$} & Constant & 69.167 & 2.018 & & 34.274 & 0.000 & \multirow{13}{*}{0.908} & \multirow{13}{*}{0.842} & \multirow{13}{*}{$13.927^{* * *}$} \\
\hline & Specificity & -1.527 & 2.053 & -.055 & -.744 & 0.467 & & & \\
\hline & Centrality & -6.052 & 2.053 & -.217 & -2.948 & $0.009 * *$ & & & \\
\hline & Proactivity & -4.660 & 2.053 & -.167 & -2.270 & $0.036 *$ & & & \\
\hline & Visibility & -7.081 & 2.053 & -.254 & -3.450 & $0.003 * *$ & & & \\
\hline & Voluntarism & -1.263 & 2.053 & -.045 & -.616 & 0.546 & & & \\
\hline & Economic responsibility & 1.569 & 2.053 & .056 & .764 & 0.455 & & & \\
\hline & Legal responsibility & 7.266 & 2.053 & .261 & 3.540 & $0.003 * *$ & & & \\
\hline & Ethical responsibility & 3.756 & 2.053 & .135 & 1.830 & 0.085 & & & \\
\hline & Philanthropy & 15.636 & 2.053 & .561 & 7.618 & $0.000 * * *$ & & & \\
\hline & Charity principle & -13.270 & 2.053 & -.476 & -6.465 & $0.000 * * *$ & & & \\
\hline & Stewardship & 5.486 & 2.053 & .197 & 2.673 & $0.016^{*}$ & & & \\
\hline & Environmental friendliness & -8.463 & 2.053 & -.304 & -4.123 & $0.001 * * *$ & & & \\
\hline
\end{tabular}

(Companies under MNCs only)

Indicators: *** Sig.<0.001, ** Sig. $<0.01, *$ Sig. $<0.05$, blank Sig. $>0.05$ 
From the above table 44, following are the observations:

The absolute beta maximum value is 0.561 for philanthropy and the absolute beta minimum value is 0.045 for voluntarism.

One standard deviation increase in specificity leads to 0.055 standard deviation decrease in value creation, keeping other variables constant. One standard deviation increase in centrality leads to 0.217 standard deviation decrease in value creation, keeping other variables constant. One standard deviation increase in proactivity leads to 0.167 standard deviation decrease in value creation, keeping other variables constant.

One standard deviation increase in visibility leads to 0.254 standard deviation decrease in value creation, keeping other variables constant. One standard deviation increase in voluntarism leads to 0.045 standard deviation decrease in value creation, keeping other variables constant.

One standard deviation increase in economic responsibility leads to 0.056 standard deviation increase in value creation, keeping other variables constant. One standard deviation increase in legal responsibility leads to 0.261 standard deviation increase in value creation, keeping other variables constant. One standard deviation increase in ethical responsibility leads to 0.135 standard deviation increase in value creation, keeping other variables constant. One standard deviation increase in philanthropy leads to 0.561 standard deviation increase in value creation, keeping other variables constant.

One standard deviation increase in charity leads to 0.476 standard deviation decrease in value creation, keeping other variables constant. One standard deviation increase in stewardship leads to 0.197 standard deviation increase in value creation, keeping other variables constant. 
One standard deviation increase in environmental friendliness leads to 0.304 standard deviation decrease in value creation, keeping other variables constant

It is observed from table 44 that only three dimensions of strategic CSR (centrality, proactivity and visibility), two categories of corporate responsibilities (legal and philanthropy) and all the three components of CSR (charity, stewardship and environmental friendliness) create value for the multinational companies operating in India. It has also been observed that specificity, voluntarism, economic responsibility and ethical responsibility does not create value for the multinational companies operating in India. 


\section{B. INDIAN PRIVATE COMPANIES}

On examining the output of regression analysis, the F-value 102.532 is significant ( $p$ value $=0.00)$. The R-square is 0.990 which means $99 \%$ of variability in value creation is accounted for by the variables in the model. The adjusted R-square shows that $98 \%$ of variability in value creation is accounted for by the model, after taking into account the number of predictor variables. The Durbin Watson statistic 2.024 indicates that the residuals are independent (Annexure VI).

The regression model is tested for normality, linearity, to detect heteroscedasticity, autocorrelation and multicollinearity and the graphs are plotted below in figures 25 , 26, 27 and 28 .

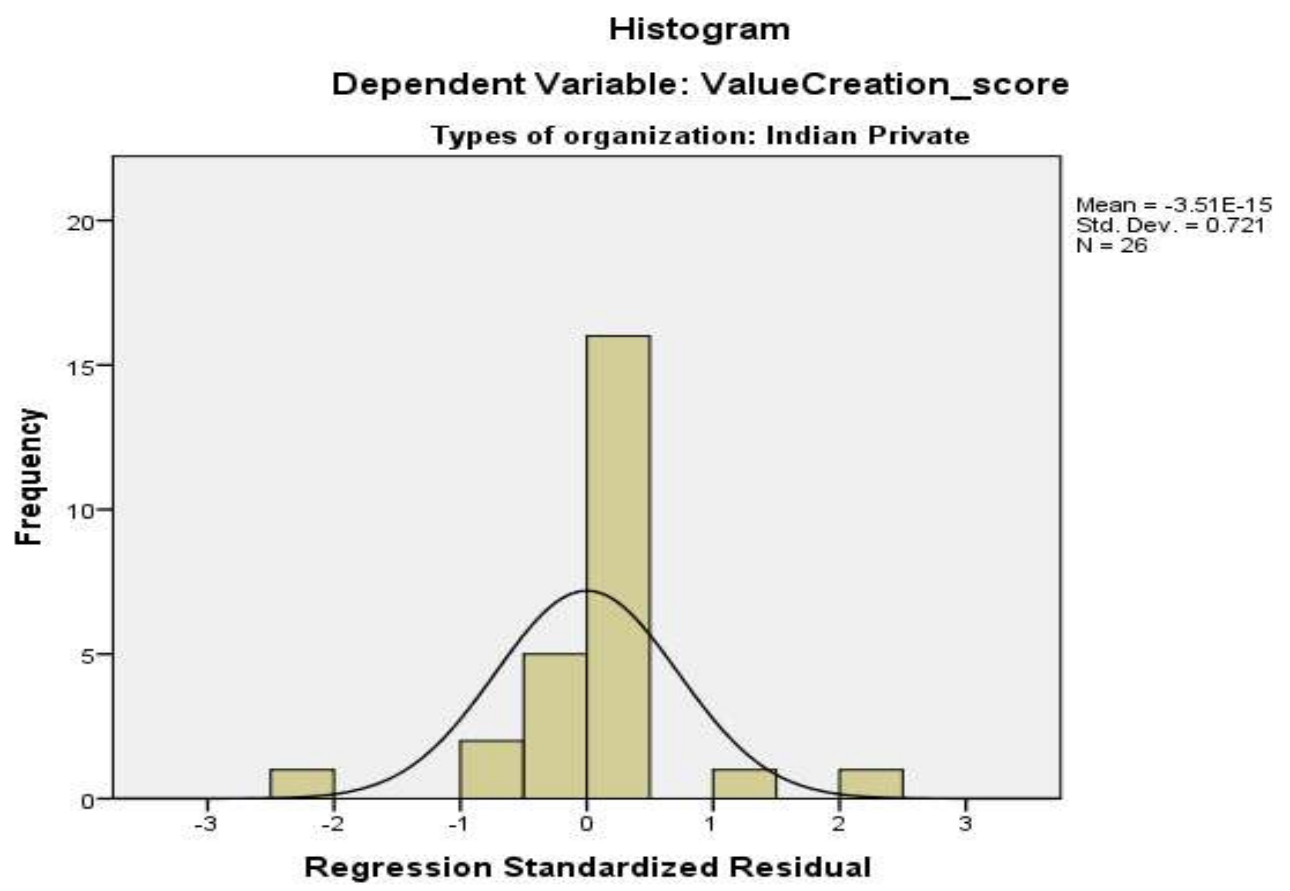

Figure 25: Test of normality for Indian private under R2 (Histogram on ZRESID versus Frequency) 


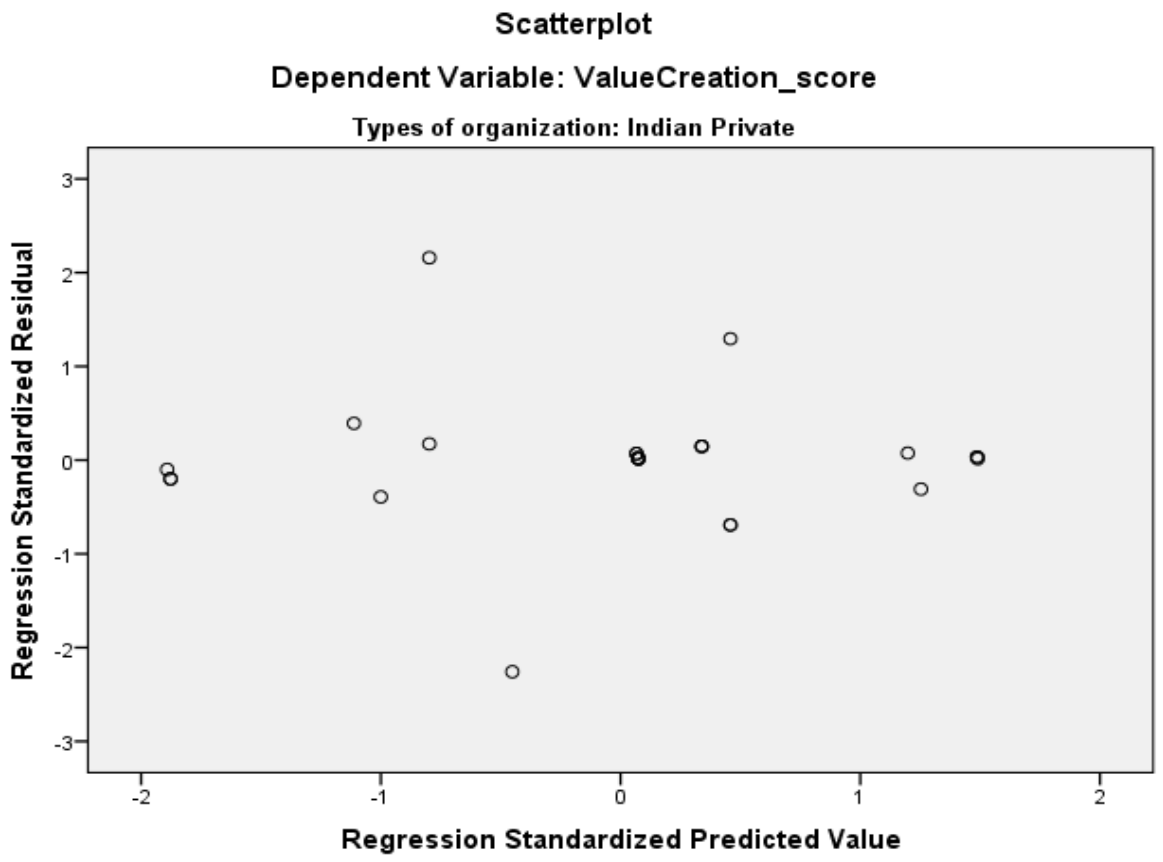

Figure 26: Test of normality for Indian private under R2 (Normal plot of ZRESID)

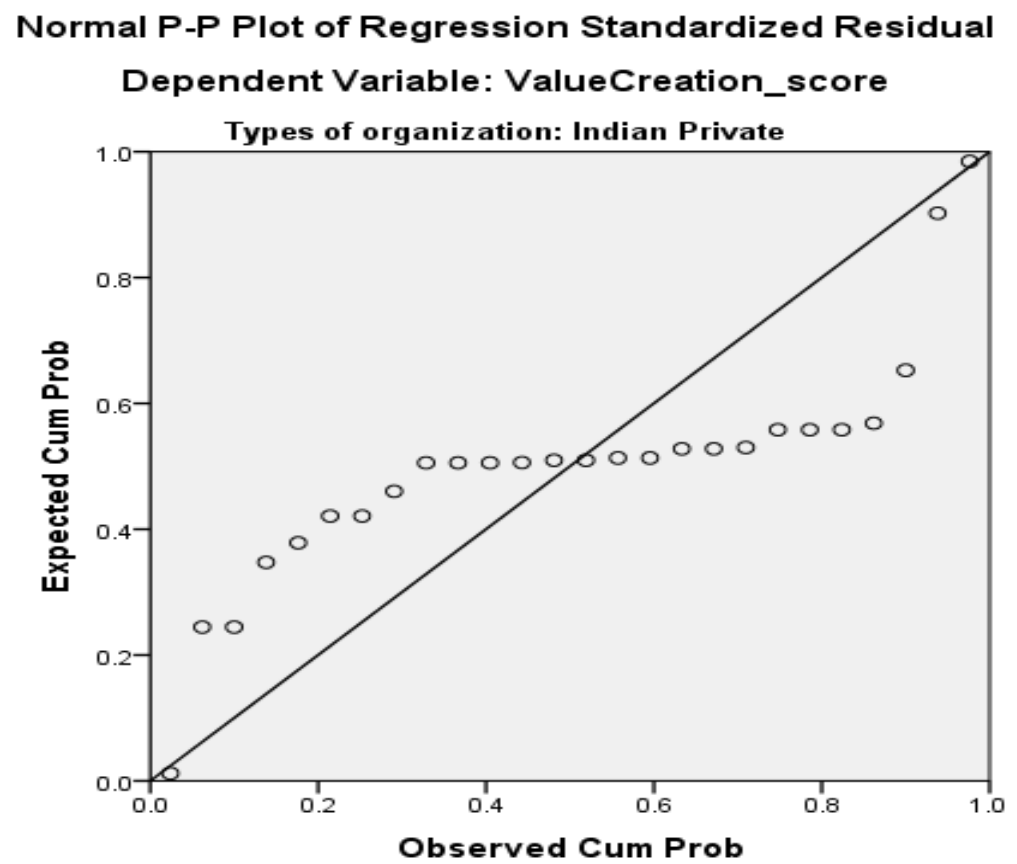

Figure 27: Test of heteroscedasticity for Indian private under R2 (ZPRED and ZRESID) 
On analyzing the plotted graph of ZPRED on $x$-axis and ZRESID on y-axis, it may be observed that there is no pattern. Therefore, it may be suggested that the regression model 2 for Indian private companies does not suffer from heteroscedasticity.

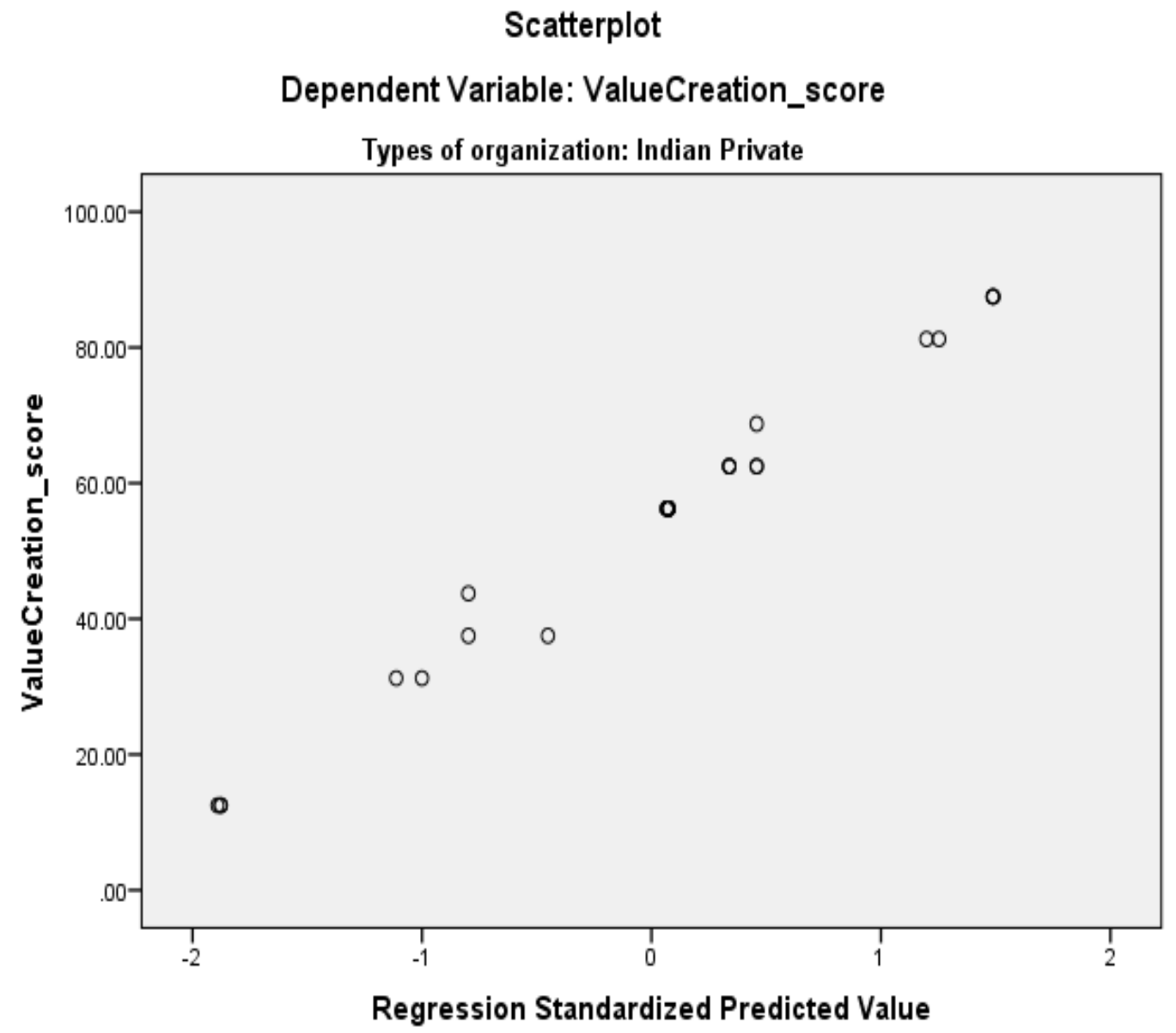

Figure 28: Test of linearity for Indian private under R2 (ZPRED versus value creation)

The above plot in figure 28 suggests that the regression model is linear. 
Table 45: Test for multicollinearity among Indian private under Regression 2

\begin{tabular}{|l|r|r|r|r|}
\hline Dimensions & Tolerance & VIF & Eigen value & Condition Index \\
\hline Constant & & & 1.000 & 1.000 \\
\hline Specificity & 1.000 & 1.000 & 1.000 & 1.000 \\
\hline Centrality & 1.000 & 1.000 & 1.000 & 1.000 \\
\hline Proactivity & 1.000 & 1.000 & 1.000 & 1.000 \\
\hline Visibility & 1.000 & 1.000 & 1.000 & 1.000 \\
\hline Voluntarism & 1.000 & 1.000 & 1.000 & 1.000 \\
\hline Economic responsibility & 1.000 & 1.000 & 1.000 & 1.000 \\
\hline Legal responsibility & 1.000 & 1.000 & 1.000 & 1.000 \\
\hline Ethical responsibility & 1.000 & 1.000 & 1.000 & 1.000 \\
\hline Philanthropy & 1.000 & 1.000 & 1.000 & 1.000 \\
\hline Charity principle & 1.000 & 1.000 & 1.000 & 1.000 \\
\hline Stewardship & 1.000 & 1.000 & 1.000 & 1.000 \\
\hline Environmental friendliness & 1.000 & 1.000 & 1.000 & 1.000 \\
\hline
\end{tabular}

The model does not suffer from multicollinearity. The tolerance is 1 and the VIF is also 1 for all variables, as depicted in the table above. 
Table 46: Regression 2 outcomes among Indian private companies (Indian private)

\begin{tabular}{|c|c|c|c|c|c|c|c|c|c|}
\hline 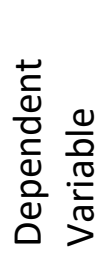 & 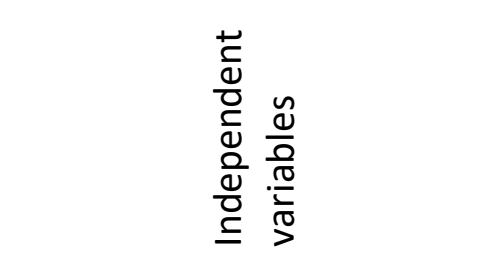 & 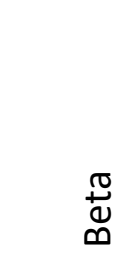 & 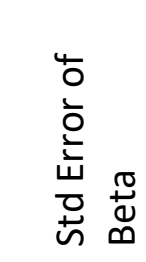 & 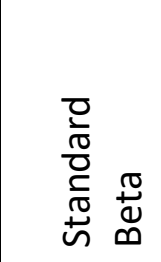 & + & $\begin{array}{l}\frac{0}{2} \\
\frac{\pi}{2} \\
\frac{1}{2}\end{array}$ & $\begin{array}{l}\frac{0}{\sigma} \\
\frac{\sigma}{\partial} \\
\tilde{\sigma} \\
\simeq \\
\propto\end{array}$ & $\begin{array}{l}\frac{0}{\frac{0}{\sigma}} \\
\frac{0}{0} \\
\frac{0}{\omega} \\
\simeq \\
\dot{0} \\
\dot{\frac{\pi}{4}}\end{array}$ & $\frac{\frac{0}{2}}{\frac{\pi}{2}}$ \\
\hline \multirow{13}{*}{ 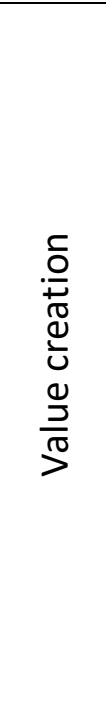 } & Constant & 54.567 & .617 & & 88.431 & 0.000 & \multirow{13}{*}{0.990} & \multirow{13}{*}{0.980} & \multirow{13}{*}{$102.532 * * *$} \\
\hline & Specificity & 6.336 & .629 & .286 & 10.069 & $0.000 * * *$ & & & \\
\hline & Centrality & -7.487 & .629 & -.337 & -11.897 & $0.000 * * *$ & & & \\
\hline & Proactivity & 4.275 & .629 & .193 & 6.794 & $0.000 * * *$ & & & \\
\hline & Visibility & 8.400 & .629 & .379 & 13.349 & $0.000 * * *$ & & & \\
\hline & Voluntarism & 7.101 & .629 & .320 & 11.284 & $0.000 * * *$ & & & \\
\hline & Economic responsibility & -6.335 & .629 & -.285 & -10.067 & $0.000 * * *$ & & & \\
\hline & Legal responsibility & 8.105 & .629 & .365 & 12.880 & $0.000 * * *$ & & & \\
\hline & Ethical responsibility & -5.168 & .629 & -.233 & -8.213 & $0.000 * * *$ & & & \\
\hline & Philanthropy & -7.721 & .629 & -.348 & -12.270 & $0.000 * * *$ & & & \\
\hline & Charity principle & 4.645 & .629 & .209 & 7.381 & $0.000 * * *$ & & & \\
\hline & Stewardship & 5.954 & .629 & .268 & 9.462 & $0.000 * * *$ & & & \\
\hline & Environmental friendliness & -1.607 & .629 & -.072 & -2.554 & $0.024^{*}$ & & & \\
\hline
\end{tabular}

(Companies under Indian private only)

Indicators: *** Sig.<0.001, ** Sig. $<0.01, *$ Sig. $<0.05$, blank Sig. $>0.05$ 
From the table 46, it may be observed that one standard deviation increase in specificity leads to 0.286 standard deviation increase in value creation, keeping other variables constant. One standard deviation increase in centrality leads to 0.337 standard deviation decrease in value creation, keeping other variables constant. One standard deviation increase in proactivity leads to 0.193 standard deviation increase in value creation, keeping other variables constant. One standard deviation increase in visibility leads to 0.379 standard deviation increase in value creation, keeping other variables constant. One standard deviation increase in voluntarism leads to 0.320 standard deviation increase in value creation, keeping other variables constant.

One standard deviation increase in economic responsibility leads to 0.285 standard deviation decrease in value creation, keeping other variables constant. One standard deviation increase in legal responsibility leads to 0.365 standard deviation increase in value creation, keeping other variables constant. One standard deviation increase in ethical responsibility leads to 0.233 standard deviation decrease in value creation, keeping other variables constant. One standard deviation increase in philanthropy leads to 0.348 standard deviation decrease in value creation, keeping other variables constant. One standard deviation increase in charity leads to 0.209 standard deviation increase in value creation, keeping other variables constant. One standard deviation increase in stewardship leads to 0.268 standard deviation increase in value creation, keeping other variables constant. One standard deviation increase in environmental friendliness leads to 0.072 standard deviation decrease in value creation, keeping other variables constant.

It may be inferred that all the five dimensions of strategic CSR (centrality, specificity, proactivity, voluntarism and visibility), four categories of corporate responsibilities (economic, legal, ethical and philanthropy) and the three components of CSR (charity, stewardship and environmental friendliness) create value for the Indian private companies operating in India. 


\section{PUBLIC SECTOR ENTERPRISES (PSES)}

On examining the output of regression analysis, the F-value 10.464 is significant ( $p$ value $=0.00$ ). The R-square is 0.84 which means $84 \%$ of variability in value creation is accounted for by the variables in the model. The adjusted R-square shows that $75.9 \%$ of variability in value creation is accounted for by the model, after taking into account the number of predictor variables. The Durbin Watson statistic is 0.914 after the second regression (Annexure VI). This value reflects autocorrelation in the above regression along the PSEs. However, the autocorrelation is not significant as confirmed by the graph in figure 33 .

The regression model 2 is tested for normality, linearity, to detect heteroscedasticity, autocorrelation and multicollinearity and the graphs are plotted below in figures 29, 30,31 and 32 .

Histogram

Dependent Variable: ValueCreation_score

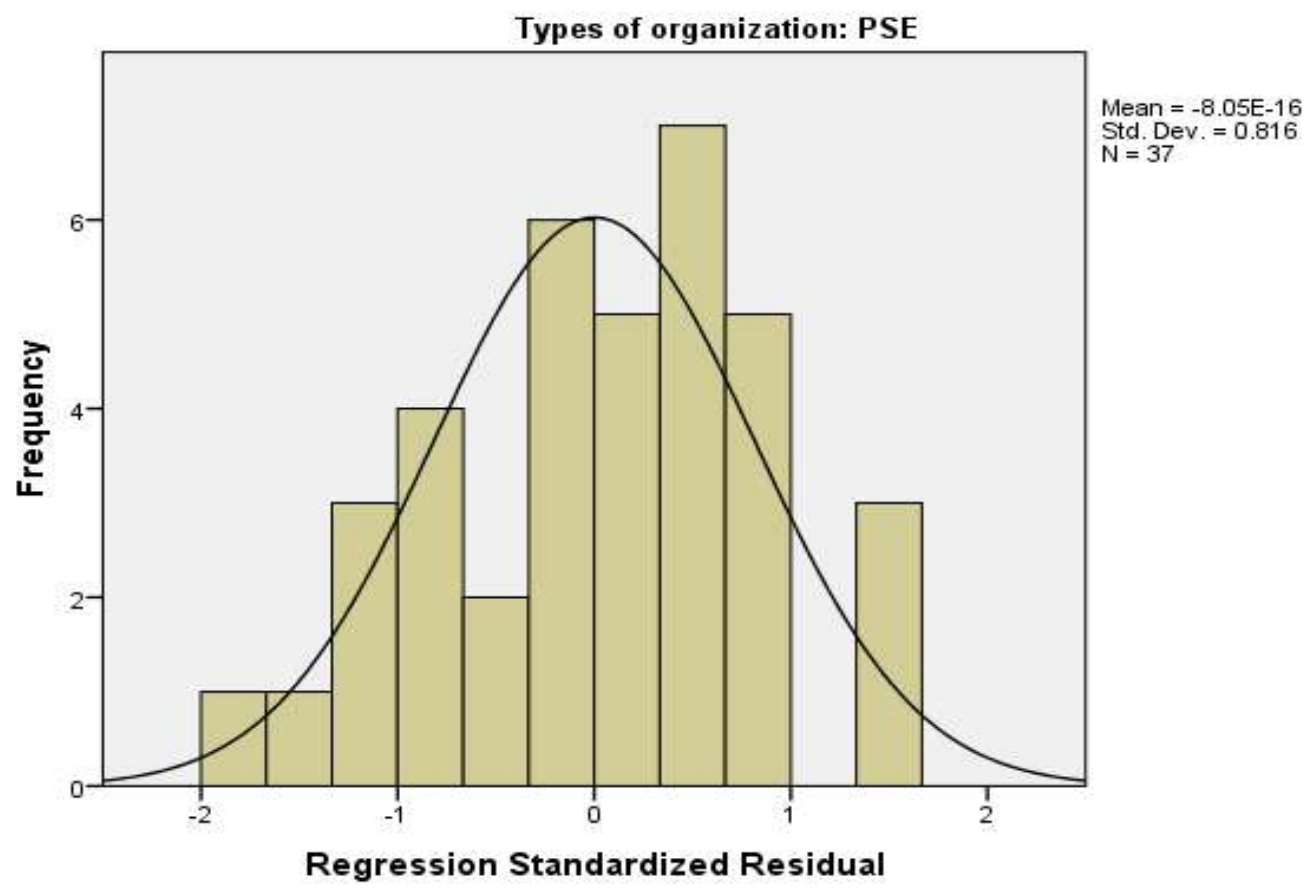

Figure 29: Test of normality for PSEs under R2 (Histogram on ZRESID versus Frequency) 
Normal P-P Plot of Regression Standardized Residual

Dependent Variable: ValueCreation_score

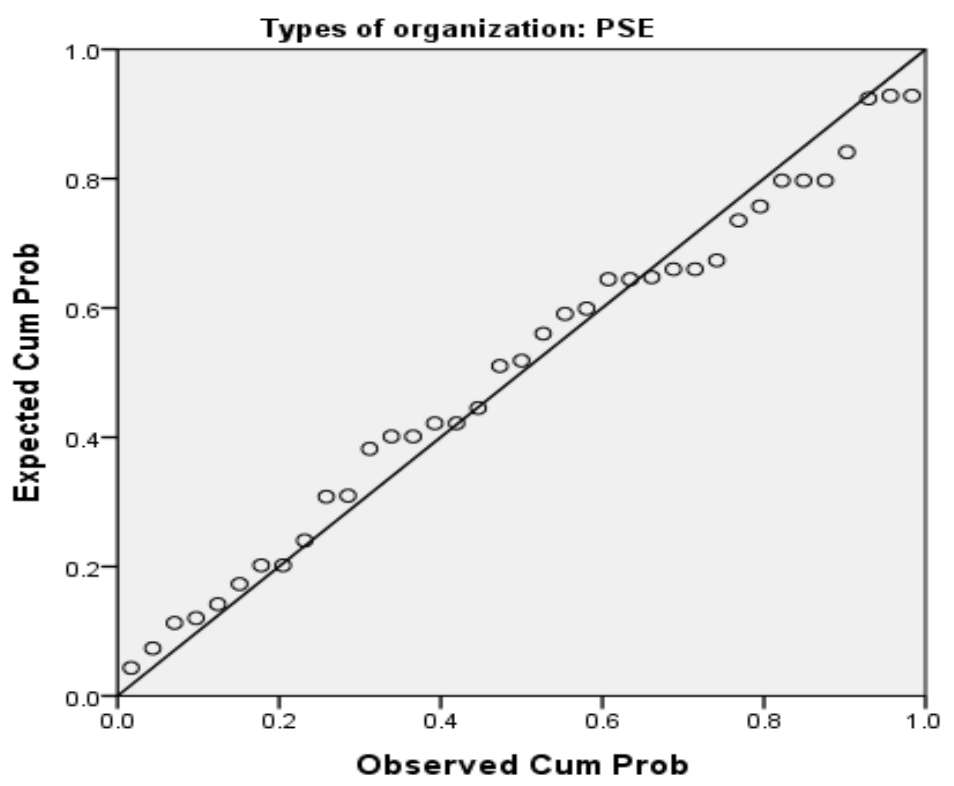

Figure 30: Test of normality for PSEs under R2 (Normal plot of ZRESID)

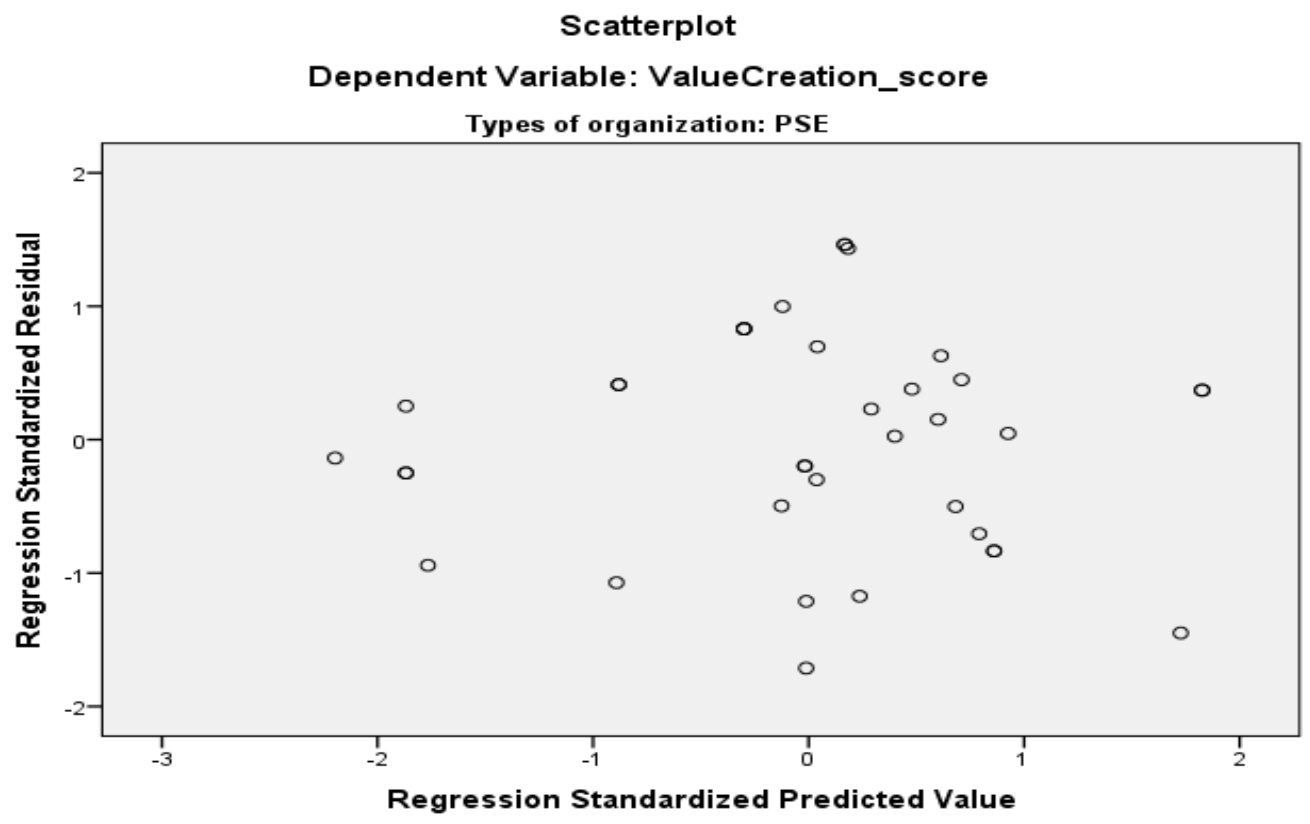

Figure 31: Test of heteroscedasticity for PSEs under R2 (ZPRED and ZRESID) 
On observing the plotted graph with ZPRED on $x$-axis and ZRESID on $y$-axis, in figure 31 above, it may be observed that there is no pattern. Therefore, we presume that the regression 2 for PSEs does not suffer from heteroscedasticity.

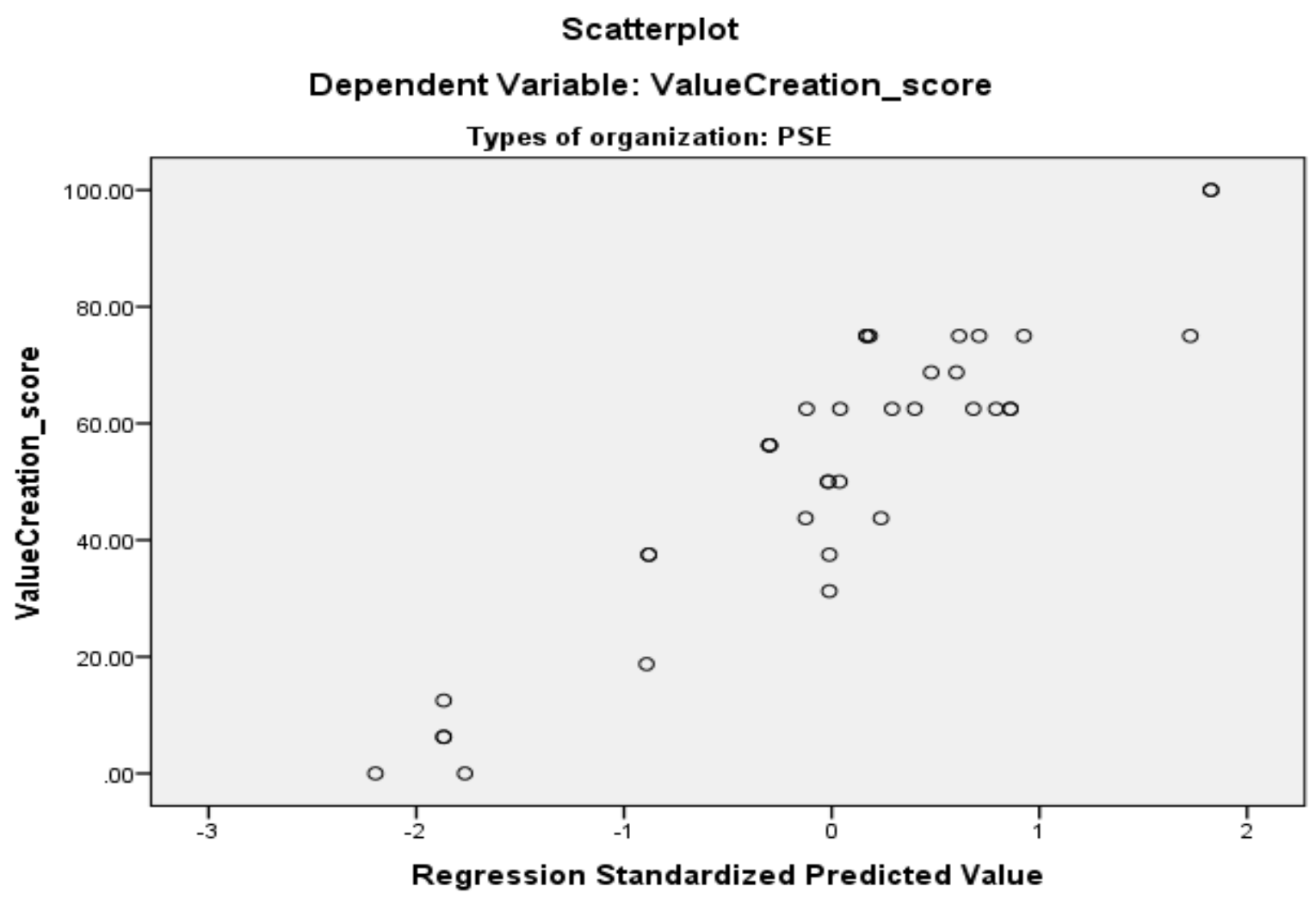

Figure 32: Test of linearity for PSEs under R2 (ZPRED versus value creation) 


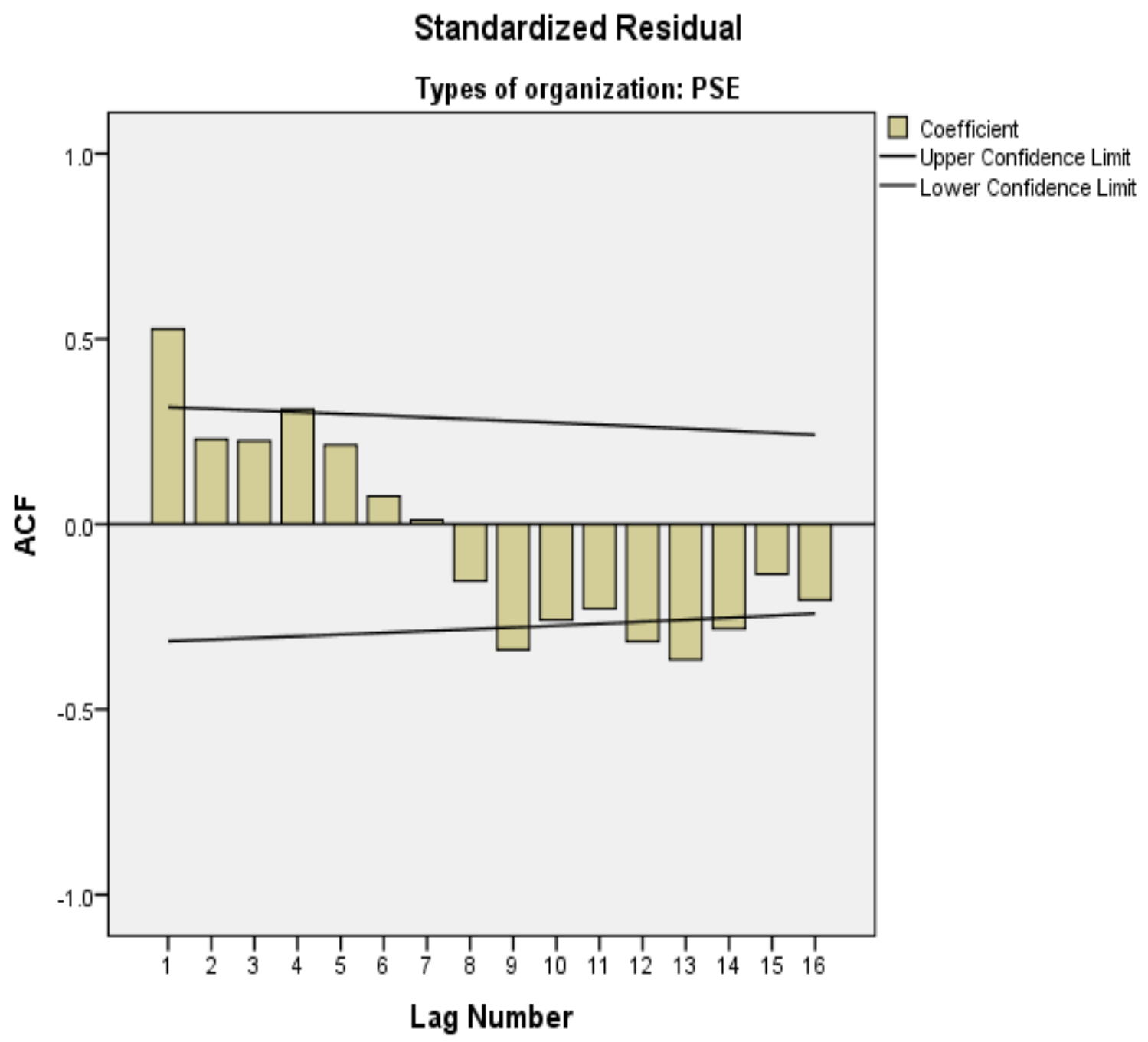

Figure 33: Test of autocorrelation among PSEs under R2

The graph in figure 33 above shows one lag outside the interval. This suggests autocorrelation. This affects beta value. Autocorrelation is treated by eliminating one component 'social support' from the variable centrality. 
Table 47: Test of multicollinearity among PSEs under Regression 2

\begin{tabular}{|l|l|l|l|l|}
\hline Dimensions & Tolerance & VIF & Eigen value & Condition Index \\
\hline Constant & & & 1.000 & 1.000 \\
\hline Specificity & 1.000 & 1.000 & 1.000 & 1.000 \\
\hline Centrality & 1.000 & 1.000 & 1.000 & 1.000 \\
\hline Proactivity & 1.000 & 1.000 & 1.000 & 1.000 \\
\hline Visibility & 1.000 & 1.000 & 1.000 & 1.000 \\
\hline Voluntarism & 1.000 & 1.000 & 1.000 & 1.000 \\
\hline Economic responsibility & 1.000 & 1.000 & 1.000 & 1.000 \\
\hline Legal responsibility & 1.000 & 1.000 & 1.000 & 1.000 \\
\hline Ethical responsibility & 1.000 & 1.000 & 1.000 & 1.000 \\
\hline Philanthropy & 1.000 & 1.000 & 1.000 & 1.000 \\
\hline Charity principle & 1.000 & 1.000 & 1.000 & 1.000 \\
\hline Stewardship & 1.000 & 1.000 & 1.000 & 1.000 \\
\hline Environmental friendliness & 1.000 & 1.000 & 1.000 & 1.000 \\
\hline
\end{tabular}

The model does not suffer from multicollinearity. The tolerance is 1 and the VIF is also 1 for all variables, as shown in the table 47 above. 
Table 48: Regression 2 outcome among public sector enterprises (PSEs)

\begin{tabular}{|c|c|c|c|c|c|c|c|c|c|}
\hline 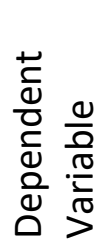 & 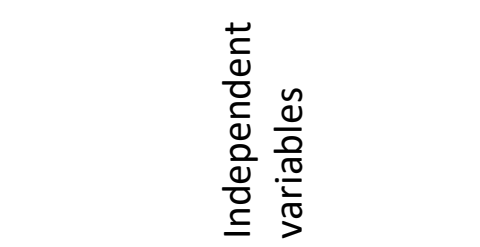 & 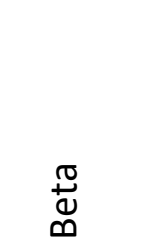 & 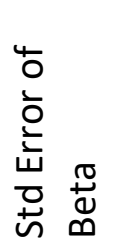 & 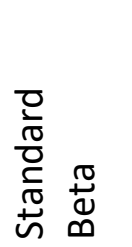 & + & $\frac{\frac{0}{2}}{\frac{\pi}{20}}$ & $\begin{array}{l}0 \\
\frac{0}{0} \\
\frac{0}{0} \\
0 \\
0 \\
\simeq\end{array}$ & 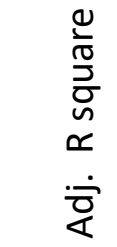 & $\frac{\frac{0}{2}}{\frac{1}{\pi}}$ \\
\hline \multirow{13}{*}{$\begin{array}{l}\frac{5}{0} \\
\frac{0}{0} \\
\frac{0}{0} \\
\frac{0}{U} \\
\frac{0}{2} \\
\frac{D}{\pi}\end{array}$} & Constant & 52.872 & 2.050 & & 25.795 & 0.000 & \multirow{13}{*}{0.840} & \multirow{13}{*}{0.759} & \multirow{13}{*}{$10.464 * * *$} \\
\hline & Specificity & 2.107 & 2.078 & .083 & 1.014 & 0.321 & & & \\
\hline & Centrality & 2.159 & 2.078 & .085 & 1.039 & 0.309 & & & \\
\hline & Proactivity & -9.451 & 2.078 & -.372 & -4.548 & $0.000 * * *$ & & & \\
\hline & Visibility & 6.150 & 2.078 & .242 & 2.960 & $0.007 * *$ & & & \\
\hline & Voluntarism & 7.959 & 2.078 & .313 & 3.830 & $0.001 * * *$ & & & \\
\hline & Economic responsibility & 4.853 & 2.078 & .191 & 2.336 & $0.028 *$ & & & \\
\hline & Legal responsibility & -5.171 & 2.078 & -.203 & -2.488 & $0.020 *$ & & & \\
\hline & Ethical responsibility & 9.244 & 2.078 & .364 & 4.448 & $0.000 * * *$ & & & \\
\hline & Philanthropy & 13.205 & 2.078 & .520 & 6.355 & $0.000 * * *$ & & & \\
\hline & Charity principle & 4.107 & 2.078 & .162 & 1.977 & 0.060 & & & \\
\hline & Stewardship & -3.692 & 2.078 & -.145 & -1.777 & 0.088 & & & \\
\hline & Environmental friendliness & -1.411 & 2.078 & -.056 & -.679 & 0.504 & & & \\
\hline
\end{tabular}

(Companies under PSEs only)

Indicators: $* * *$ Sig. $<0.001, * *$ Sig. $<0.01, *$ Sig. $<0.05$, blank Sig. $>0.05$ 
From table 48 above, it may be observed that the absolute beta maximum value is 0.520 for philanthropy and the absolute beta minimum value is 0.056 for environmental friendliness.

One standard deviation increase in specificity leads to 0.083 standard deviation increase in value creation, keeping other variables constant. One standard deviation increase in centrality leads to 0.085 standard deviation increase in value creation, keeping other variables constant. One standard deviation increase in proactivity leads to 0.372 standard deviation decrease in value creation, keeping other variables constant. One standard deviation increase in visibility leads to 0.242 standard deviation increase in value creation, keeping other variables constant. One standard deviation increase in voluntarism leads to 0.313 standard deviation increase in value creation, keeping other variables constant.

One standard deviation increase in economic responsibility leads to 0.191 standard deviation increase in value creation, keeping other variables constant. One standard deviation increase in legal responsibility leads to 0.203 standard deviation decrease in value creation, keeping other variables constant. One standard deviation increase in ethical responsibility leads to 0.364 standard deviation increase in value creation, keeping other variables constant. One standard deviation increase in philanthropy leads to 0.520 standard deviation increase in value creation, keeping other variables constant.

One standard deviation increase in charity leads to 0.162 standard deviation increase in value creation, keeping other variables constant. One standard deviation increase in stewardship leads to 0.145 standard deviation decrease in value creation, keeping other variables constant.

One standard deviation increase in environmental friendliness leads to 0.056 standard deviation decrease in value creation, keeping other variables constant 
It is observed from the table 48 that only three dimensions of strategic CSR (proactivity, visibility and voluntarism), the four categories of corporate responsibilities (economic, legal, ethical and philanthropy) create value for the public sector enterprises operating in India. It has also been observed that two dimensions of strategic CSR (centrality and specificity), along with the three components of CSR (charity, stewardship and environmental friendliness) does not create value for the public sector enterprises operating in India.

\subsection{Reliability test}

Cronbach's alpha

Table 49: Reliability statistics

\begin{tabular}{|l|r|r|}
\hline Types of organization & Cronbach's Alpha & \multicolumn{2}{|c|}{ N of Items } \\
\hline MNCs & .732 & 21 \\
\hline Indian private & .861 & 21 \\
\hline PSEs & .717 & 21 \\
\hline
\end{tabular}

Initially, the Cronbach's alpha for public sector enterprises (PSEs) reflected a value of 0.69 which is close to the minimum required value of 0.70 . In order to enhance reliability of the data, one component 'social support' from 'centrality' is removed. The final Cronbach's alpha obtained for PSEs is 0.717 , as depicted in table 49 above.

The Cronbach's alpha for MNCs, Indian private and the PSEs are above 0.70. As a result, the individual clusters of companies satisfy the reliability requirements (Cronbach's alpha for individual components are given in Annexure VII). 
On examining the formulated hypotheses and recording observations from tables 44 , 46 and 48 obtained from regression analysis 2 of MNCs, Indian private companies and PSEs, the following may be inferred for the firms operating in India:

H1: The three dimensions of strategic CSR (centrality, proactivity and visibility) create value for multinational companies. All five dimensions of strategic CSR (centrality, specificity, proactivity, voluntarism and visibility) create value for Indian private companies, and only three dimensions of strategic CSR (proactivity, voluntarism and visibility) create value for public sector enterprises.

H2: Only two categories of corporate responsibilities (legal responsibility and philanthropy) create value for multinational companies. All four categories of corporate responsibilities (economic, legal, ethical and philanthropy) create value for Indian private companies and public sector enterprises.

H3: The three components of CSR (charity, stewardship and environmental friendliness) create value for multinational companies and Indian private companies only.

And,

Two dimensions of strategic CSR (specificity and voluntarism) do not create value for multinational companies.

Similarly, two dimensions of strategic CSR (centrality and specificity) do not create value for public sector enterprises.

Only two categories of corporate responsibilities (economic and ethical responsibilities) do not create value for multinational companies.

The three components of CSR (charity, stewardship and environmental friendliness) do not create value for public sector enterprises only. 


\section{CHAPTER 7}

\section{CONCLUSIONS}

\subsection{Introduction}

This chapter contains summary of major findings, conclusions and recommendations on corporate sustainability and CSR initiatives of companies operating in India, the variables of five dimensions of strategic CSR by Burke \& Logsdon (1996) namely centrality, specificity, proactivity, visibility and voluntarism and their relationship to value creation; Carroll's (1991) pyramid of CSR namely economic responsibility, legal responsibility, ethical responsibility and philanthropic responsibility; Lawrence, Weber \& Post's (2005) principle of charity and stewardship, and environmental friendliness and their relationship to value creation for firms operating in India. This chapter discusses details of research findings and conclusions of the study.

Following are key observations from the study:

The Government of India, in 2013 enacted a law under the Section 135 of the Indian Companies Act making CSR mandatory for companies "having net worth of rupees five billion or more, or turnover of rupees ten billion or more or a net profit of rupees fifty million or more during any financial year to spent $2 \%$ of the average net profits made during the three preceding years towards CSR" (Jain \& Gopalan 2017).

All profit making public sector enterprises in India has already initiated CSR activities beginning year 2009 whereas majority of the private sector and multinational companies started initiation on CSR only after the mandatory law has been passed.

India remained on the top spot for decades among nations with people living in extreme poverty. The 2019 Global Multidimensional Poverty Index (MPI) released by the UN suggests that over 640 million people across India lived in multidimensional poverty during 2006/2007, and that fell steeply to slightly more than 365.55 million by 2016/2017, an impressive reduction of 271 million (McCarthy 2019). India has initiated 
several ambitious programmes aimed at improving living standards of its people. During 2001 , only $55.8 \%$ of the population had access to electricity, and this has increased to 92.612\% during 2017 (World Bank 2019b). During 2013, only 40\% of the population had access to household toilet. Under Clean India campaign initiated by the Prime Minister in October 2014, the basic sanitation coverage across the country is $99.45 \%$ as of July 2019 (McCarthy 2019).

The world has set a deadline 2030 to eradicate extreme poverty (World Bank 2019). The World Bank (2015) estimates that the amount of money required to lift people above the poverty line of $\$ 1.90$ a day is $\$ 60$ billion a year (Rao 2017). The cost of funding Sustainable Development Goals has gone up significantly. The estimated cost of SDG financing (2030 Agenda for Development), including extreme poverty eradication by 2030 is expected to be US\$6 trillion a year or US\$ 90 trillion over 15 years (United Nations 2017). The Addis Ababa Action Agenda (AAAA) suggests \$1 trillion to 1.5 trillion annually in developing countries to bridge the global infrastructure gap (United Nations 2015).

\subsection{Conclusions from the study}

\subsubsection{Corporate Sustainability and CSR initiatives practiced by companies}

The qualitative study on Corporate Sustainability and CSR initiatives (chapter 5) suggests that PSEs have performed better compared to that of Indian private companies and MNCs, both on individual category as well as absolute and relative terms (table 21).

In terms of social development, Indian private companies (31.31) scored higher compared to that of MNCs (23.17) and PSEs (21.73). Indian private recorded $44 \%$ higher than MNCs and 35\% higher than PSE in this important category.

On comparing the environmental category, the PSEs (19.56) have performed better than MNCs (14.56) and Indian private (12.76). In this study, the PSEs recorded 53\% higher than MNCs and $34 \%$ higher than the Indian private respectively in this important category. 
In the education \& skill building category, MNCs (22.51) and PSEs (19.56) were comparable where as the Indian private (10.63) recorded only about half of that of the MNCs. PSEs performed $84 \%$ better than Indian private and MNCs performed $15 \%$ better than PSEs in this segment.

In the manufacturing operations/processes which are internal to the companies, MNCs (17.21), Indian private companies (12.76) and PSEs (3.26) respectively. The MNCs performed 5 times higher than the PSEs in this category. The MNCs reflected 35\% higher than the Indian Private in the manufacturing operations.

In the energy conservation category, the PSEs (16.30) recorded higher compared to that of Indian private (7.44) and MNCs (almost negligible). The PSEs were twice compared to that of the Indian private.

Providing sanitation and clean drinking water is a major initiative undertaken by the PSEs (7.60) compared to that of Indian private (low) and MNCs (insignificant). In the category of health care, Indian private (8.51) and PSEs (5.43) were comparable whereas that of MNC (4.63) were lower. Indian private performed 83\% better than MNCs and $60 \%$ better than PSEs in the healthcare segment.

MNCs (7.94) and Indian private (7.44) were comparable in the category stakeholder engagement and PSEs recorded low (2.17). MNCs and Indian private were about 3.5 times higher than PSEs in stakeholder engagement.

It may also be noted that the MNCs have advantages over Indian private and PSEs in the area of corporate governance $(\mathrm{MNCs}=4.63)$ and innovation $(\mathrm{MNCs}=3.97)$. Indian private scored high in disaster relief $(5.31)$ compared to that of the PSEs $(2,17)$ whereas MNCs were not significant in this area. Indian private were 2.4 times more than that of PSEs in this area.

Among the three clusters of companies sampled in the qualitative study, overall relative performance of corporate sustainability and CSR activities per company is highest with PSEs, followed by Indian private and MNCs respectively in the decreasing order. 


\subsubsection{Dimensions of strategic CSR and market value creation}

Centrality is a relevant dimension of strategic CSR that significantly influences value creation. According to this study, the centrality focus was significant in creating value among the MNCs (p-value=0.009), Indian private ( $p$-value=0.000). However, centrality was not significant among the selected PSEs ( $p$-value=0.309). According to Kanter (1999), "the centrality may help the organization to re-allocate resources, utilize products and processes of the organization for CSR. This helps company achieve competitive advantage" (Kanter 1999). Opportunity exists for research in this area of identifying relationship between centrality and product/process innovation. However, with the implementation of mandatory CSR by the Government of India, a major change is being observed in the recent years with regard to CSR being central to the business objective of large firms in India.

Specificity is an important component of value creation since it enables an organization to capture specific benefits (Burke \& Logsdon 1996). The current study suggests that Indian private $(p$-value $=0.000)$ alone reflected a significant relationship between specificity and value creation whereas the MNCs ( $p$-value=0.467) and the PSEs ( $p$-value $=0.321$ ) did not suggest significant relationship between specificity and value creation. This may be due to the reason that CSR efforts undertaken by the selected MNCs and PSEs were not adequate, or the MNCs and PSEs did not pay much importance to these specific CSR programmes. The PSEs were undertaking some kind of CSR since 2009, aimed at contributing to social development whereas it was not the case with that of MNCs. The private sector with profit motive had a specific goal of enhancing revenue and profitability through positioning its brands in the market place.

Proactivity was significant among all the companies- the MNCs ( $p$-value=0.036), the Indian private companies $(p$-value $=0.000)$ and PSEs $(p$-value $=0.000)$ in creating value in India. The PSEs are regulated by government and are subjected to strict guidelines 
and policies in their operations. All the PSEs are required to undertake CSR activities as per the guidelines set by Department of Public Enterprises. The multinational companies are also subjected to liberal investment guidelines. The intense competition and liberal policies announced by the government encourages companies to be proactive, plan strategy and venture into the CSR arena.

The private companies in India compete in capturing market share, and meticulously chart out strategies to be a winner in the market place. For example, in the Indian pharmaceutical industry, companies Ranbaxy Laboratories, Torrent Laboratories, Dr Reddy's Laboratories, Cipla, Cadila Laboratories, Sun Pharmaceuticals, etc. were able to secure large market share through innovative approaches, employing reverse engineering, interior market penetration, reaching the target segment through low cost pricing and launching products at a faster pace through creation of successful strategic business divisions.

In the case of MNCs, as suggested by Husted and Allen, there may be a possibility that "the CSR initiatives were developed/initiated at home country headquarters and the branches or subsidiaries monitor the host-country environment to respond proactively to the needs of the local communities" (Husted \& Allen 2006). "The stakeholders in the home countries may be driving CSR activity more than stakeholders in host countries (Husted \& Allen 2006), especially when referring to the newly industrializing economies like India. The managers in the subsidiaries of multinational companies are experienced professionals and their main focus is towards developing business and sustaining them. Therefore, the managers of MNCs aim on creating competitive advantage through CSR by making it a part of the corporate strategy.

Visibility is related to value creation as confirmed by all the companies - MNCs (pvalue $=0.003)$, Indian private $(p$-value $=0.000$ ) and PSEs ( $p$-value $=0.007)$. This finding confirms to the idea that the purpose of implementing CSR programme is to create a 
favourable image, maintain and consolidate the image of company by communicating the values generated by the organization through the media. Thus, visibility develops an identity which in turn is translated into customers' positive feelings for the company. The visibility factor is an important component of value creation among all the companies.

Voluntarism is an essential element necessary for creation of value. The original work done by Burke and Logsdon (1996) suggests that voluntarism is directly proportional to value creation, reflecting a direct relationship. In this study, voluntarism creates value among Indian private ( $p$-value $=0.000)$ and PSEs ( $p$-value $=0.001)$. Although voluntary CSR activities may be altruistic (selfless), it has been observed that voluntarism did not create value among the MNCs ( $p$-value $=0.546$ ). It may be interpreted that Indian private companies and PSEs tend to be inclined towards voluntarism since these companies are domestic companies, and therefore, are responsible towards the society.

For those companies prone to scrutiny, or subjected to strict regulations, the likely chances of undertaking voluntary CSR programmes are high. An example is the transformation of ITC in India. In 1906, British American Tobacco Company (BAT) launched its operations of manufacturing and selling of tobacco products in India. BAT found it difficult to survive in a competitive tobacco business since granulated tobacco was not accepted by the Indians. Therefore, in 1912, BAT created Imperial Tobacco Company (which later became ITC in 2001), and encouraged social activities such as weaving, sports, farming, art and other activities in order to promote its products. The Imperial Tobacco Company invested heavily in India after its independence, when several foreign companies quit. It created subsidiary handloom mills generating employment to almost 1800 people (Nayak 2010); and invested in paper and hotels. The company has been able to win over the people of India and the government by focusing on marketing, diversification and social responsibility. "The shareholding pattern of ITC reflects voluntarism towards social responsibility. The 
Indian government financial institutions own $37 \%$ of ITC shares, BAT holds around $31 \%$ and remaining with the Indian public. Today, ITC is dedicated to serve the bottom of the Indian pyramid" (Dasgupta 2011).

\subsubsection{Pyramid of CSR and market value creation}

According to Novak (1996), the set of seven economic responsibilities are "achieving customer satisfaction through delivering goods and service of real value; providing a reasonable return on investment for the funds entrusted to the company by the investors; generating new wealth for non-profit institutions that owns shares in publicly held organizations, and help the poor and the needy to elevate their living standards; generating new employment opportunities; overcome envy by encouraging people on positive developments; promoting innovation; and diversifying economic interest of the people in prevent tyranny of the majority."

In this study, significant relationship has been reported between economic responsibility and value creation among Indian private $(p$-value $=0.000)$ and PSEs $(p-$ value $=0.028$ ) whereas no significant relationship has been observed between economic responsibility and value creation for MNCs ( $p$-value=0.455). It is also reported that legal responsibility was significant among all the companies-MNCs (pvalue $=0.003)$, Indian private $(p$-value $=0.000)$ and PSEs ( $p$-value $=0.020)$ suggesting that all the companies selected obeyed the law, and that adhering to legal requirements helped them create value.

According to Carroll (2001), ethical responsibilities are those policies and business practices which are expected from a company and are not coded in the law. Carroll (2001) indicated that adhering to ethical responsibility enables a company in building trust and positive attitude, which contribute to value creation. Ethical responsibility is the outcome of humane principle, moral traditions and beliefs, human rights commitment and religious conviction (Novak 1996). This study suggests that there exists a relationship between ethical responsibility and value creation among Indian 
private companies $(p$-value $=0.000)$ and PSEs $(p$-value $=0.000)$ whereas ethical responsibility was not significant in creating value among the MNCs ( $p$-value $=0.085$ ). There is a need to investigate further into identifying reasons for this relationship among the MNCs.

It is believed that philanthropy influences value creation of firms, and this is further confirmed by this study. According to this study, CSR influences the philanthropy of companies among the MNCs ( $p$-value $=0.000)$, Indian private sector ( $p$-value $=0.000$ ) and PSEs (0.000). All the companies in the study believed that contributing to philanthropy leads to value creation.

\subsubsection{Stewardship, charity principle and market value creation}

According to Lantos (2002), 'it is the duty of the manager to loyally serve the employer by contributing to profit maximization.' The stewardship of corporation's resources may be displayed with a view of serving the society' (Lantos 2002). Stewardship creates value among the MNCs ( $p$-value $=0.016)$ and Indian private ( $p$ value $=0.000$ ) whereas stewardship did not reflect value creation among the PSEs ( $p$ value $=0.088$ ). Charity reflected value creation among the MNCs ( $p$-value $=0.000)$ and Indian private sector companies ( $\mathrm{p}$-value $=0.000$ ). Charity did not show any significant value creation among the PSEs ( $p$-value $=0.060$ ). This suggests that there is no association between charity and stewardship in creating value among the PSEs sampled.

\subsubsection{Environmental friendliness and market value creation}

Environmental friendliness has reflected a positive association with promotion of an effective CSR policy, which in turn creates value among MNCs ( $p$-value $=0.001)$ and Indian private companies ( $p$-value $=0.024)$. This may due to the reason that most of the companies in the study are engaged in the manufacturing sector, especially in the chemical, energy and infrastructure industry which requires adherence to strict 
environmental standards and regulations. It is surprising to note that environmental friendliness did not create value among the PSEs ( $p$-value=0.054) and the same requires a thorough investigation. The services industry in India, especially the information technology has grown ahead of the manufacturing sector leaving the agricultural sector far behind. The information technology services sector is dominated by large Indian companies and does not require strict environment regulations as in the case of manufacturing sector.

\subsection{Approaches to social value creation}

Corporate social responsibility is a strategy that helps organizations in considering the interests of all stakeholders within the organization and the society. These are some approaches that depict the role of CSR in creating value for the organization. According to Maskrey (1989), the first step to this is the community based approach wherein the company identifies local communities in order to work together to solve a community problem. For example: Oil and Natural Gas Commission (ONGC) has a 'corporate citizen policy' for promoting community development, education, healthcare, water resource management, entrepreneurship in its project areas in Assam, India. The company distributed more than 140 computers to various educational institutions in remote areas with an aim of spreading IT education and awareness. In addition to offering scholarships to meritorious students during the year 2005-2006, the oil company ONGC is focused on uplifting weaker section of the society in the backward villages through organizing entrepreneurship schemes, medical camps, healthcare facilities and constructing schools for the villagers in the community (Das \& Halder 2011).

An approach to creating value is integrating CSR into business strategy (Baron 2001, Galbreath 2006). For example, procurement of fair trade commodities such as tea and coffee has been identified through several sources of business including KPMG (Bansal \& Roth 2000, Dentchev 2004). Shared value may be created by connecting 
commercial success and social welfare (Nohria \& Ghoshal 1994). According to this approach, 'in order to achieve a position at the top level in Carroll's pyramid (philanthropy), it is necessary to create income, wealth, revenue and opportunities through sustainable, tangible and intangible resources' (Bansal \& Roth 2000).

'Value network' refers to the tangible and intangible resources and their interaction, which are included in the value or net gain in the products or services of the company. According to a study conducted by Normann \& Ramirez (1993), 'value generation system includes several members- such as suppliers, customers, competitors, who collaborate and deliver value to the company and the society' (Normann \& Ramirez 1993). The key components of the value network are the 75 framework of McKinsey (strategy, structure, systems, style, skill, staff and shared vision). The present study examines the causes of CSR value creation through social action projects among companies operating in India. It may be stated that 'value creation appears to be related to centrality and visibility' (Burke \& Logsdon 1996). In view of the research findings, the companies are required to be proactive in taking advantage of the economic benefits resulting from the CSR initiatives. There is a need to strategically monitor business and social environment to take advantage of the CSR initiatives.

There are important issues raised by the findings of CSR research. One possible interpretation of these results may be that the CSR undertaken by MNCs in India may be less sophisticated than that practiced by MNCs in their home countries. It also may be similar to those CSR practiced by the Indian companies in India. This lack of sophistication could also be due to the fact that Indian customers may not be 'as demanding as home-country customers'. Another reason could be that the MNCs 'customize their strategies and adapt them to the markets they compete'. There is a need to analyze CSR and its purpose in the context of the Indian stakeholders. 


\subsection{Applicability of research findings}

The findings in this study support the applicability of dimensions of strategic CSR (centrality, specificity, proactivity, visibility and voluntarism) by Burke \& Logsdon (1996), Carroll's (1991) pyramid of CSR (economic, legal, ethical and philanthropy), and Lawrence, Weber \& Post's (2005) principle of charity and stewardship, and environment friendliness amongst the enterprises operating in India. For example: proactivity, visibility, legal responsibility and philanthropy scored high. Managers should be aware that even though CSR primarily suggests social and ethical concerns, many individuals give importance to legal responsibility as part of the comprehensive definition of CSR.

Generally, philanthropy is easy for an organization because it involves donations. This is not so with the case of the stewardship function which is sometimes viewed as a narrower aspect of CSR. It should be recognized that the stewardship duty has a broader agenda as it compels business to be "trustees", an obligation to function in the interest of the society. This fits with the contemporary emphasis of stakeholder management which goes beyond the shareholders to include employees, consumers, public, government and activists.

\subsection{CSR and stakeholders}

The importance of CSR and its impact on corporate conduct has been studied previously by Carroll (1999) who remarked that the best CSR programme should not only be socially supportive but also be an important tool to contribute to the values of the company by being economically profitable. The previous section examined the importance of CSR in building up the value of the firm, while this section focuses on how CSR should be identified with the stakeholders. Following issues are considered in relation to role of CSR among different stakeholders involved. 


\subsubsection{CSR influenced by employees}

It is observed that social pressure from employees forms a major part of CSR initiatives undertaken by a company. This is found to be particularly true for MNCs and private companies in India. From the results it is observed that similarities among Indian private companies, PSEs and MNCs with regard to proactivity and visibility of the CSR programme.

On analyzing the results, the researcher feels that self-motivated proactive employees identify social causes much more specifically. It has been indicated by Raj Kumar (2008) that there is a very strong increase in the number of multinational companies in India and that their entry corresponds to a significant increase in the total CSR activities of the country. Relating this view to the results of this study, it is seen that the presence of MNCs has not only increased the CSR initiatives but also has had an effect on the private sector enterprises in India. Research done by Tymon et al. (2010) showed that "qualified labour is a scarce resource in fast-growing emerging markets including India." Therefore, the Indian companies, especially in the services industry, should put in efforts in order to retain their employees.

Research conducted by Lindgreen et al. (2009) shows that CSR plays a vital role in promoting stakeholder belief and attitude towards the firm. The presence of an effective CSR programme would help build a positive attitude of employees towards a company irrespective of its origin (either Indian domestic or multinational companies). Employees or potential employees who are aware of the CSR initiatives undertaken by the companies positively associate and identify with the companies. This may prompt them to use products of the company as well as invest in these companies as shareholders. It is possible to identify that CSR activity may not only improve community relationship but also the intent of stakeholders (in this case the employees) to invest their personal resources in the company. The survey by Yang \& Rivers (2009) has shown that when a company attempts to involve in community 
development, it nurtures rapport with potential employees. The pressures from employees also make CSR initiatives undertaken by the companies to be more visible in nature.

Also, it may be identified that assistance offered by companies to initiate social projects, either Indian or MNC demonstrates a growing influence of employees in building a rapport with the community. This is likely to increase the specificity of project initiatives. From the viewpoint of the company it is observed that engagement in a community development program helps the company not only in building trust with the employees but also visibility of the company in the locality as a business partner, a good corporate citizen, and an attractive employer. In an article with headline: "Amazing story of a businessman who gifted cars, flat to staff." Rediff Business dated October 24, 2014 reports the story of "Dholakia brothers of Hari Krishna Exports based in Surat, Gujarat, a diamond export company that extended its gratitude to over 1,200 employees who helped the company grow. 491 employees received cars, 207 received cash for buying a residential apartment and 507 received jewels. Each employee received gift worth INR 400,000 (\$6607) (Rediff.com 2014)."

Dholakia brothers became a highly sought after employer overnight. The Dholakia brothers started diamond business in 1984 and achieved an export business of INR 10 million $(\$ 165,180)$ during the first year of its operations. When the diamond industry went into rough weather, many small time traders went into farming. These traders returned when the industry prospects turned brighter. Currently the company is doing an export business of INR 60,000 million (\$991.08 million). The company budgeted INR500 million (\$8.259 million) towards employee loyalty programme. The Dholakia brothers credit their business to the motivated employees. The valuable lesson learnt is the 'art of sharing prosperity' through appreciating human efforts (Rediff.com 2014). 


\subsubsection{CSR and the role of government}

Social pressure from the government reflects the ability of the local governments in influencing companies' social efforts such as good working conditions (e.g.: adequate rest hours and social security) or engagement in the local community. Historically, social regulations in several emerging markets are relatively weak compared to the standards set by the MNCs. Some emerging countries suffer from ineffective control and enforcement mechanisms (Christmann \& Taylor 2006, Sharfman et al. 2004). More recently, the governments in emerging economies have started to emphasize CSR as a part of their development objectives, and also actively involving MNCs in pursuing this strategy.

An example of this strategy is project Shakti, co-initiated by Indian government and Unilever. This project fosters empowerment of women in rural areas by training them as sales professionals, as mentioned in the review of literature. Therefore, expectations from stakeholders including the Indian government, has an influence on the operations of Unilever in India.

\subsection{Proposed framework}

The proposed framework involves application of Carroll's pyramid (1996) along with charity, stewardship and environmental friendliness considering firms of various sizes (small, medium, large and very large firms). A comparison of the responsibilities amongst small, medium and large firms and very large firms could be analyzed, as shown in figure 34 below.

The economic dimension focuses on the obligations of businesses in creating wealth and meeting consumption requirements. This dimension is the foundation upon which other dimensions sustain, maximize earning per share, assert a position of competitiveness, and hold high level of operational effectiveness. The new 
framework suggests personal savings rate, business savings rate, inflation and manufacturing lead time as indicators to measure the economic dimension.

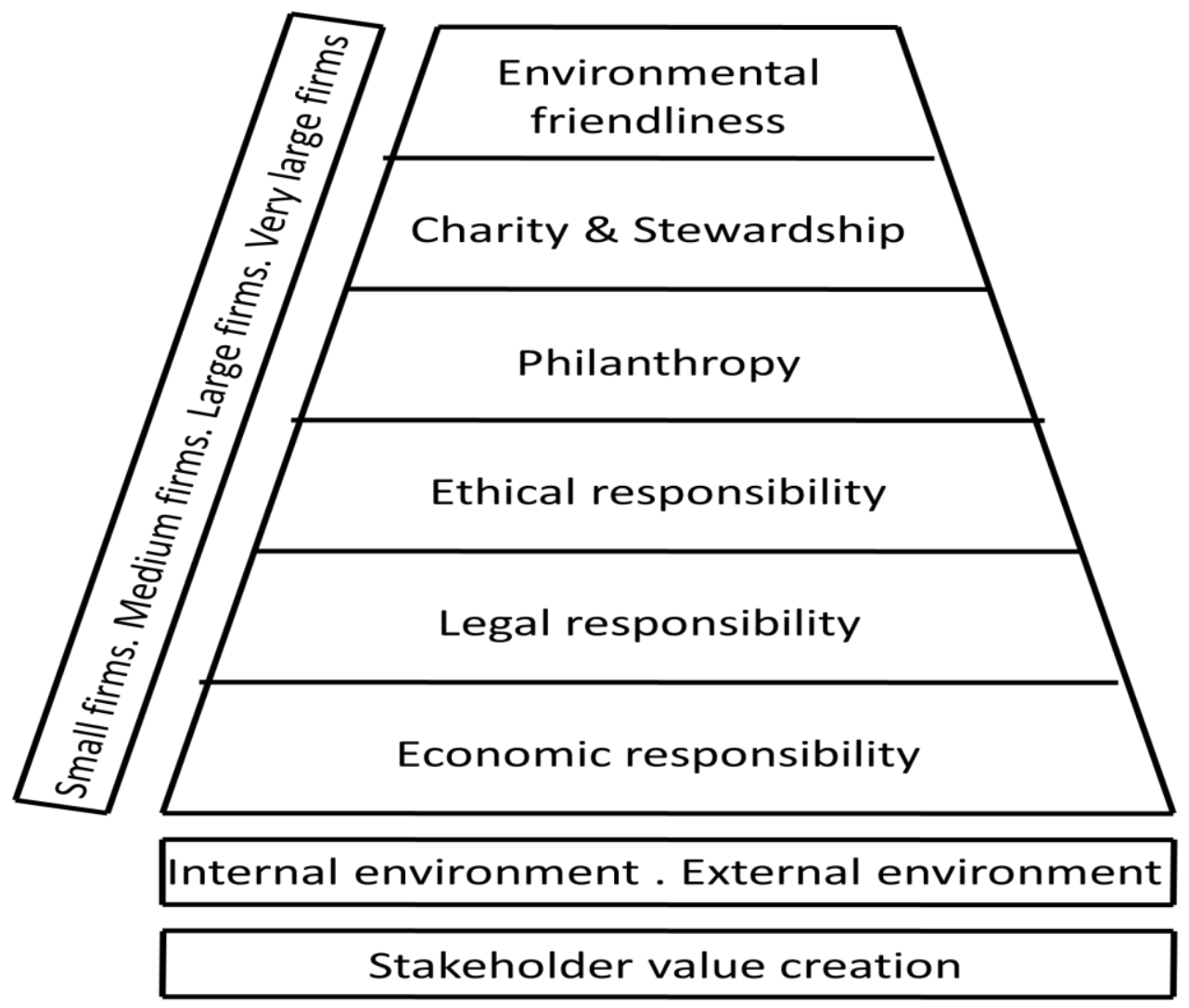

Figure 34: Proposed framework (Source: Current study)

The legal responsibility dimension lays emphasize on the business processes to execute the vision and mission of the company for the economic benefit and meeting the legal requirements. These responsibilities are important in order to carry out as required by the government and as expected by the law. Therefore, corporations must produce goods and services meeting all legal requirements. The study proposes anti-trust laws, labor laws, employee welfare laws, taxation laws, training laws and human right for measuring these responsibilities.

The ethical responsibility is the third dimension which focuses on the ability of business to do what is right, just and fair. Moral rules define suitable behaviors in the 
organizations and the society. These responsibilities meet the expectations of social morals and ethical norms accepted by the society. Some variables such as codes of conduct, prevention of corruption, and money laundering have also been suggested.

The philanthropy is the discretionary responsibility required to be a good corporate citizen. And likewise focus on contribution of resources for the community and improvement in standard of living as an indicator for community. The managers and employees of the company undertake charitable activities and provide services such as establishing educational and skill training institutions to meet the expectations of the society. Stewardship is an essential requirement of managers and employees to conduct duties with diligence. It is the responsibility of every individual to protect natural resources (biological, ecological and geological environment) and preserve biodiversity for economic growth and poverty reduction.

An account of the degrees of responsibilities along the stages of company's life cycle from conception to growth, maturity, saturation and decline would help in identifying the corporate responsibility strategy among various industries. As mentioned in the literature, the fundamental role of corporate social responsibility is to create value for the organizations and the society. Both internal and external environment are effected in the value creation cycle.

\subsection{Future recommendations}

An area of future research may be to examine the successful cases of strategic CSR by MNCs and domestic firms in a longitudinal study. The expectations set up by Burke \& Logsdon (1996) framework are only partially supported by MNCs and domestic companies in India. It would be useful to study the CSR attributes of MNCs in countries that are economically and socially similar to India. Future study should also consider different activities of the multinational enterprises along the supply chain. Other areas include examining whether MNCs from developed home countries differentially engage in CSR depending upon whether the host country is developed 
or less developed country. It would be equally useful to examine how MNCs from developing home countries understand their CSR role in developed countries. It would be important to include objective measures of value creation beyond the subjective, self-reports of the respondents. For e.g.: In the United States, financial data is much more readily available and research could take advantage of these objective measures. In order to understand the interaction of strategic variables at the firm level, a case-based examination is required.

Application of systems engineering concepts such as systems requirements engineering and systems design in the area of CSR would be useful in identifying the CSR requirements of countries based on the needs of the community. This would enable the companies to develop a need based CSR strategy focused on generating value to the stakeholders of the nation. The first step to this research would be to plot an 'onion diagram' of stakeholders (figure 35) of CSR and perform a mapping based on 'power /interest' matrix (Johnson \& Scholes 1999) as given in figure 36.

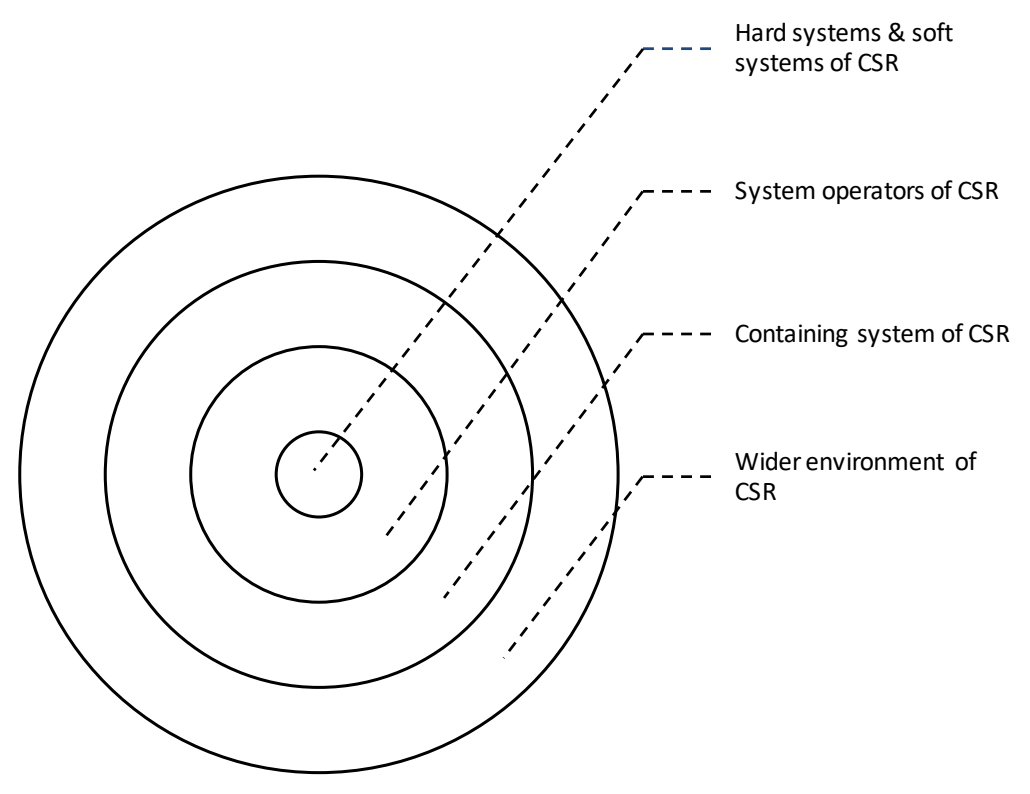

Figure 35: Onion diagram of stakeholders (Source: Systems Requirements Engineering Module 2012 UCL Centre for Systems Engineering) 


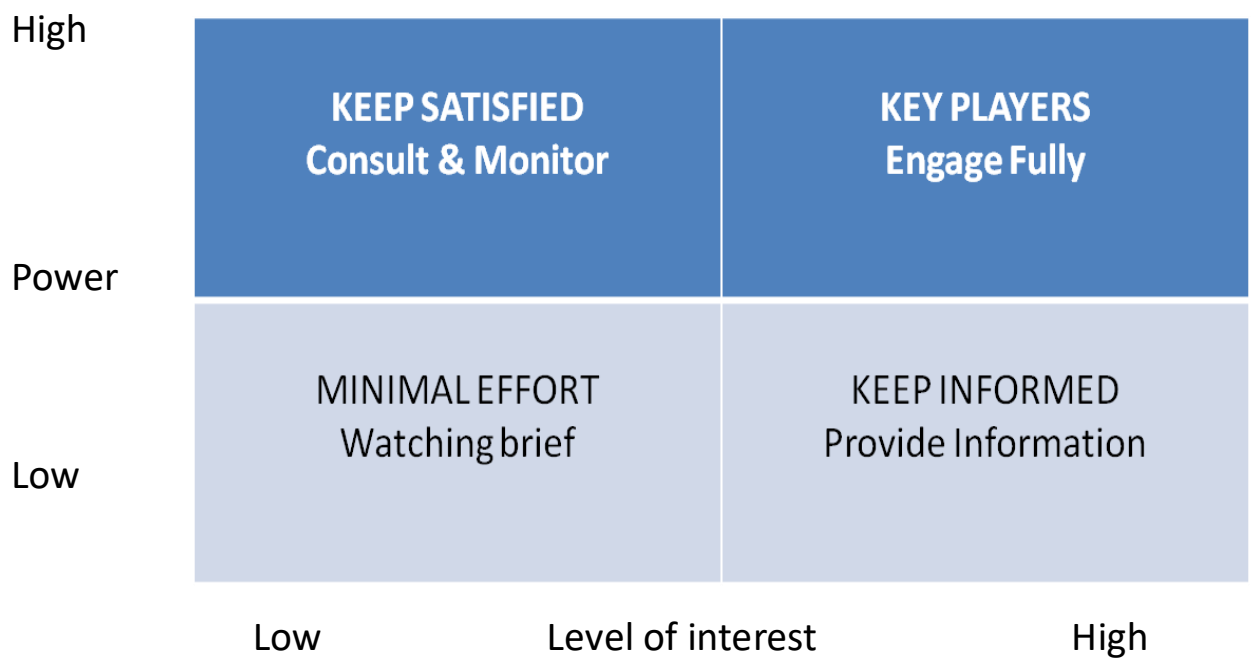

Figure 36: Power / Interest matrix (Source: Johnson \& Scholes 1999)

Once the key stakeholders are identified using the above model, the next step is to analyse the CSR requirements of key stakeholders as shown in figure 37 below.

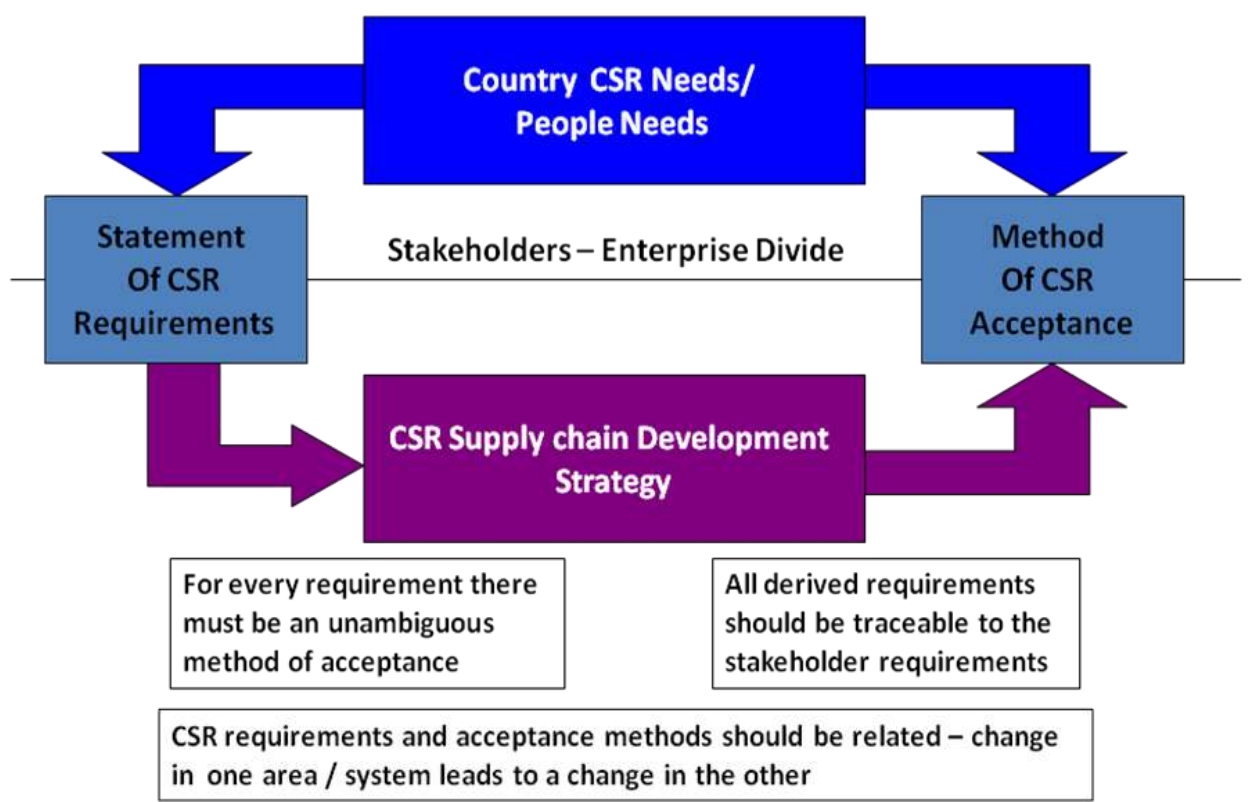

Figure 37: Designing CSR requirements and acceptance (Source: Adapted from Systems Requirements Engineering Module 2012, UCL Centre for Systems Engineering) 


\section{Sources of CSR requirements}

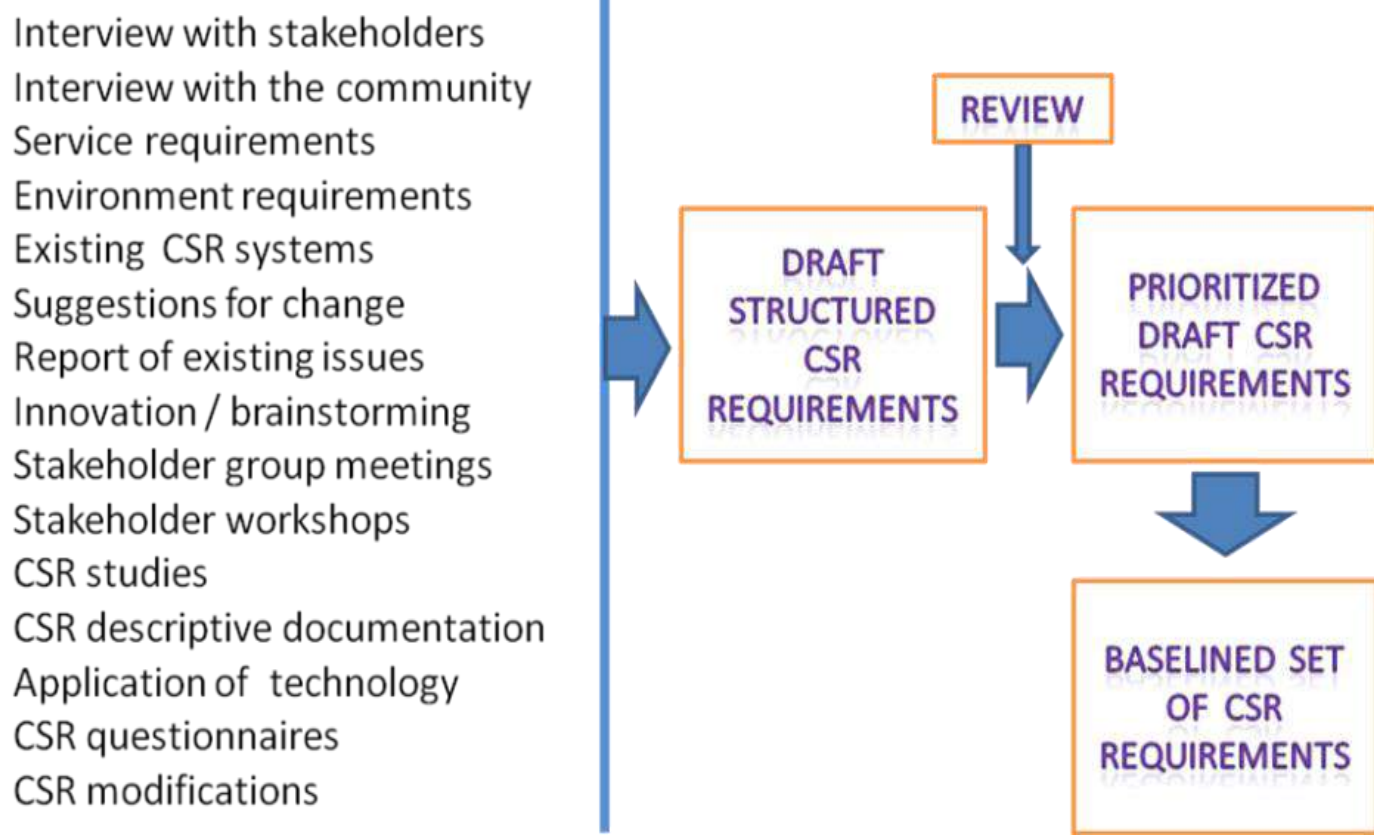

Figure 38: Eliciting CSR requirements (Source: Adapted from Stevens et al. 1998)

Eliciting CSR requirements helps bridge the gap between CSR supply and demand, making optimum use of resources (figure 38).

Another important area of research is Life Cycle Assessment (LCA) of products and processes along the supply chain in reducing environmental impact. Several large multinational companies in the manufacturing industry such as Procter and Gamble, SKF, etc. work towards achieving this goal of developing products that are environment friendly and sustainable. Although almost every company claims to possess sustainable and environment friendly policies and publish reports, there is a need to understand the degree or the extent of sustainability along the supply chain and the level of involvement in meeting those requirements. 


\subsection{Limitations}

There are certain limitations to the conducted research. The samples in the qualitative study were limited to 43 and quantitative study have been restricted to 93 firms. The only way to generalize results of this study is to extend the search to an expanded sample by including more firms. It is important to factor in certain limitations that cannot be controlled by the researcher, including the location, the time at which data was collected, exhaustion and interest of the contributor. The researcher initially emailed questionnaires 2 and 3 using personal email id to 520 company executives and there were no responses. Subsequently, researcher could contact the senior executives through Indian Chamber of Commerce (ASSOCHAM), which resulted in positive responses from several large corporations. Thus the questionnaires were completed through both personal interaction and with the support of ASSOCHAM. The senior management of large public sector enterprises was cooperative and shared their achievements on CSR and future strategies.

Moreover, collecting primary data from the multinational corporations has been challenging since the senior executives were busy personnel with limited time and some of the senior executives of the multinational corporations were not willing to meet in person and discuss on CSR. The awareness levels of CSR among the employees of firms were very low and that some of the company personnel at the receiving end (telephone operators) during a telephonic appointment were not aware of CSR, a few have not heard of the term CSR. The quantitative research data were collected during the period $2010-2011$ when the CSR was voluntary and awareness level of CSR were low. During this period, CSR was mainly undertaken mainly by large public sector corporations.

The researcher has no control on value chain activities in the organization's processes and therefore do not know the impact of several activities that might have on value creation. Most multinational firms operating in India are engaged in producing a part 
of the value chain. Some of them are involved in the assembly of parts manufactured in other countries whereas most others are engaged in marketing and distribution. A few other multinational companies that have achieved operational efficiency undertake manufacturing activity.

\subsection{Concluding remarks}

This research is one of the first studies conducted on identifying the perception of CSR in India. Some of the findings support applicability of five dimensions of CSR by Burke \& Logsdon (1996), Carroll's Pyramid of CSR (1999) constructs, and Lawrence et al. (2005) charity and stewardship principle, and environment responsibility. While there is adequate appreciation for more socially responsible business operations, future studies should refine the concept and examine the different dimensions or components that could help companies understand what they should do in order to improve their CSR efforts. It is hoped that with more research in this area, there will be greater consciousness among business leaders, employers and employees to think and act with responsibility and accountability towards the society upon which the business exists. 


\section{REFERENCES}

Published Sources

Acutt, N. J. et al. (2004). Perspectives on Corporate Social Responsibility in the Chemical Sector: A Comparative Analysis of the Mexican and South African Cases. Natural Resources Forum, Vol. 28, Issue. 4, 302-316

Adenekan S. Abiola (2007). Putting CSR into perspective. The World, San Francisco, Vol. 24, Issue. 6, 48

Agle, B. R., Mitchell, R. K. \& Sonnenfield, J. A. (1999). Who matters to CEOs? An investigation into stakeholder attributes and salience, corporate performance and CEO values. Academy of Management Journal, 42(5)

Ahmad, S. J. (2006). From Principles to Practice: Exploring Corporate Social Responsibility in Pakistan. Journal of Corporate Citizenship, Vol. 24, winter 115-29

Albareda, L. et al. (2007). Public policies on corporate social responsibility: the role if governments in Europe. Journal of Business Ethics, Vol. 74, Issue 4, pages 391-407

Alon, Ilan et al. (2010). Usage of public corporate communications of social responsibility in Brazil, Russia, India and China (BRIC). International Journal of Emerging Markets, Vol. 5, Issue 1. pages 6-22

Altman, B.W. \& Vidaver-Cohen, D. (2000). A framework for understanding corporate citizenship. Introduction to the special edition of Business and Society Review 'Corporate Citizenship for the New Millennium'. Business and Society Review, 105, 1-7

Amaeshi, K. M. et al. (2006). Corporate Social Responsibility in Nigeria: Western Mimicry or Indigenous Influences? Journal of Corporate Citizenship, Vol. 24, 83-99

Andrew, B. H., Gul, F. A., Guthrie, J. E. \& Teoh, H. Y. (1989). A note on corporate social disclosure practices in developing countries: The case of Malaysia and Singapore. British Accounting Review, Vol. 21, Issue 4, 317-376

Ansoff, H. I. (1965). Corporate Strategy, New York: McGraw-Hill, London

Ansoff, H. I. (1977). Managing surprise and discontinuity: strategic response to weak signals, In H B, Thorelli, Strategy plus Structure Equals Performance. Indiana University Press, Bloomington, IN, 53-82

Ansoff, H. I. (1983). Societal strategy for the business firm, In JAI Press: Greenwich. CT Advances in Strategic Management, Vol. 1, 3-29

Arora, B \& Puranik, R. (2004). A Review of Corporate Social Responsibility in India. Development. Vol. 47, No. 3, 93-100

Araya, M. (2006). Exploring Terra Incognita: Non-financial Reporting in Latin America. Journal of Corporate Citizenship. Vol. 21, 25-38

Asemah, E.S., Okpanachi, R.A and Olumuji, E. O. (2013a). Communicating corporate social responsibility performance of organisations: A key to winning stakeholders' goodwill. International Journal of Arts and Humanities. Vol. 2 (3)

Asemah, E.S., Okpanachi, R.A and Olumuji, E.O. (2013b). Universities and corporate social responsibility performance: An implosion of the reality. African Research Review. Vol. 7(4) 
Aupperle, K. E., Carroll, A. B. \& Hatfield, J. D. (1985). An empirical examination of the relationship between corporate social responsibility and profitability. Academy of Management Journal, Vol. 28, No. 2, 446-463

Aupperle, K., Hatfield, J.D. and Carroll, A.B. (1983). Instrument development and application in Corporate Social Responsibility. Academy of Management Proceedings. August Vol 1, pp.369-373

Balasubramanian (2007). Corporate Social Responsibility. USP AGE, July, 18-26

Balasubramanian, N. K. et al. (2005). Emerging Opportunities or Traditions Reinforced? An Analysis of the Attitudes Towards CSR, and Trends of Thinking about CSR, in India. Journal of Corporate Citizenship, Vol. 17, 79 - 92

Bapna, A. (2007). Corporate Social Responsibility. USP AGE, 18-26

Barney, J. B. 1986. Strategic Factor Markets: Expectations, Luck, and Business Strategy. Management Science, Vol. 32, No. 10, 1231-1241

Barney, J. B. (1991). Firm resources and sustained competitive advantage. Journal of Management, Vol. 17, No. 1, $99-120$

Barney, J. B. (2001). Is the Resource-Based 'View' a Useful Perspective for Strategic Management Research? Yes. Academy of Management Review, Vol. 26, No. 1, 41-56

Barney, J. B. (2001). Resource-based theories of competitive advantage: A ten-year retrospective of the resourcebased view. Journal of Management, Vol. 27, 643-650

Barone, M. J., Miyazaki, A. D. \& Taylor, K. A. (2000). The influence of cause-related marketing on consumer choice: does on good turn deserve another? Journal of the Academy of Marketing Science, Vol. 28, No. 2, 248-262

Baskin, J. (2006). Corporate Responsibility in Emerging Markets. Journal of Corporate Citizenship, Vol. 24, 29-47

Baur, R. A. \& Fenn, D. H. Jr. (1973). 'What is a Corporate Social Audit?' Harvard Business Review, January February, 37-48

Beaudoin, S. (2009). New Age of Cause Marketing. PR Newswire, New York

Becker-Olsen, K. L., Cudmore, B. A. \& Hill, R. P. (2006). The Impact of Perceived Corporate Social Responsibility on Consumer Behaviour. Journal of Business Research, Vol.59, 46-53

Bendell, J. (2000). Terms for Endearment: Business, NGOs and Sustainable Development. Sheffield: Greenleaf

Berman, S., Wicks, A., Kotha, S. \& Jones, T. (1999). Does stakeholder orientation matter? The relationship between stakeholder management models and firm financial performance. Academy of Management Journal, Vol. 42, No. 5, 488-506

Bhattacharya, B. K. (2008). GOI-UNDP Project, Strengthening State Plans for Human Development, Evaluation Report

Bhattacharya, C. B. \& Sen, S. (2003). Consumer-Company Identification: A Framework for Understanding Consumers' Relationship with Companies. Journal of Marketing, Vol. 67, 76- 88

Bhattacharya, C. B. \& Sen, S. (2004). Doing better at doing good: when, why, and how consumers respond to corporate social initiatives. California Management Review, Vol. 47, No. 1, 9-24 
Bhattacharyya, S. S. \& Sahay, A. (2007). Collective Corporate Response to Terrorism and Naxalism. Shailesh J. Mehta School of Management, SJMSOM, Indian Institute of Technology, IIT Bombay. 10th Annual Strategic Management Forum, SMF, Convention

Bijoor, H. (2008). Role of CSR in Modern Marketing. Brand Line, Business Line, 14 February

Birch, D. \& Moon, J. (2004). Introduction: Corporate Social Responsibility in Asia. Journal of Corporate Citizenship, $18-23$

Bird, R. \& Hall, A. D. et al. (2007). What Corporate Social Responsibility Activities are valued by the Market? Journal of Business Ethics, Vol. 76, 189-206

Black, B. (1999). National culture and labour-market flexibility. The International Journal of Human Resource Management. Vol. 10, no. 4, 592-605

Black, S. (1999). The right way to manage expats. Harvard Business Review, 52-62

Blair, J. D. \& Whitehead, C. J. (1989). Too Many on the Seesaw: Stakeholder Diagnosis and Management for Hospitals. Hospital \& Health Services Administration, Vol. 33, No. 2, 153- 166

Blowfield \& Frynas, J. G. (2005). Setting New Agendas: Critical Perspectives on Corporate Social Responsibility in the Developing World. International Affairs, Vol. 81, No. 3, 499-513

Blowfield, M. (2003). Ethical Supply Chains in the Cocoa, Coffee and Tea Industries. Greener Management International, Vol. 43, 15-24

Blowfield, M. (2004). Implementation Deficits of Ethical Trade Systems: Lessons from the Indonesian Cocoa and Timber Industries. Journal of Corporate Citizenship. Vol. 13, 77-90

Bonini, Sheila, M. J., Lenny, T. Mendonca, Jeremy, M. Oppenheim (2006). When Social Issues become Strategic. The McKinsey Quarterly, No. 2, 20-32

Bowen, H. R. (1953). Social responsibilities of the businessman. New York: Harper \& Row

Bowie, N. E. \& Freeman, R.E. (1992). Ethics and Agency Theory: An Introduction. Oxford University Press, Oxford, England, 3-21

Boyatzis, R. (1998). Transforming qualitative information. Thematic analysis and coding development. Thousand Oaks, CA: Sage

Bradley, A. R. (1999). Who matters to CEOs? An investigation of stakeholder attributes and salience, corporate performance and CEO values. Academy of Management Journal, Briarcliff Manor: Oct, Vol. 42, No. 5, 507-526

Branco, M. \& Rodrigues, L. (2006). Corporate social responsibility and resource-based perspectives. Journal of Business Ethics. Vol. 69, 111-132

Branzei, Onana (2010). Tata: Leadership with Trust. Richard Ivey School of Business Case Collection, London. May 11

Braun, V. \& Clarke, V. (2006). Using thematic analysis in psychology. Qualitative research in psychology 3(2): 77101 
Brennan, R. \& Baines, P. (2006). Is There a Morally Right Price for Antiretroviral Drugs in the Developing World? Business Ethics: A European Review. Vol. 15, No. 1, 29-43

Brink et al. (2006). The effect of strategic and tactical cause-related marketing on consumers' brand loyalty. Journal of Consumer Marketing. Vol. 23, No. 1, 15-25

Bronn, P. S. \& Vrioni, A. B. (2001). Corporate social responsibility and cause-related marketing: An overview. International Journal of Advertising. Vol. 20, No. 2, 207-222

Bryman, A. \& Cramer, D. (1990). Quantitative Data Analysis for Social Scientists. London: Routledge

Bryman, A. \& Cramer, D. (2001). Quantitative Data analysis with SPSS. Release 10 for Windows: A guide for social scientists, Philadelphia: Routledge

Bryman, A. \& Bell, E. (2007). Business Research Methods: Oxford. Oxford University Press

Burke, L. et al. (1986). Corporate community involvement in the San Francisco Bay Area. California Management Review. Vol. 28, No. 3, 122-141

Burke, L., Logsdon, J. (1996). How Corporate Social Responsibility Pays Off. Long Range Planning, Vol.29, No. 4, 495-502

Campbell, J. L. (2007). Why would corporations behave in socially responsible ways? An institutional theory of corporate social responsibility. Academy of Management Review. Vol. 32, No. 3, 948-967

Cannon, T. (1994). Corporate Responsibility- A Textbook of Business Ethics. Pitam Publishing, London

Carroll, A. B. (1979). A three-dimensional conceptual model of corporate social performance. Academy of Management Review, Vol. 4, 496-505

Carroll, A. B. (1991). The Pyramid of Corporate Social Responsibility: Toward the Moral Management of Organizational Stakeholders. Business Horizons, Vol. 34, 39-48

Carroll, A. B. (1993). Business \& Society: Ethics and Stakeholder Management. 2nd Ed, Cincinnati, OH: SouthWestern Publishing Co.

Carroll, A. B. (1998). The four faces of corporate citizenship, Business and Society Review, Vol. 100, 1-7

Carroll, A. B. (1999). Corporate Social Responsibility: Evolution of a Definitional Construct, Business \& Society, Vol. 38, No. 3, pp. 268-295

Carroll, A. B. \& Buchholtz, A. K. (2000). Business and Society: Ethics and Stakeholder Management, 4th edition, Cincinnati, Ohio: South-Western College Publishing

Carroll, A. B. (2016). "Carroll's pyramid of CSR: Taking another look". Carroll International Journal of Corporate Social Responsibility

Carroll, A.B. \& Buchholtz, A.K. (2014). Business and Society: Ethics, Sustainability and Stakeholder Management, $9^{\text {th }}$ edition, Stamford, Cengage Learning

Carron, M. P. (2004). Is there Anyone Listening? Women workers in factories in Central America, and Corporate Codes of Conduct, Development, Vol. 47, No. 3, 101-5 
Carron, M. P. et al. (2006). Critical perspectives on CSR and development: What we know, what we don't know, and what we need to know'. International Affairs, Vol. 82, No. 5, 977-87

Chambers, E., Chapple, W., Moon, J. \& Sullivan, M. (2003). CSR in Asia: A seven country study of CSR website reporting. ICCSR Research Paper Series, Nottingham University, Nottingham, UK

Chandrasekar, M. (2006). What's your company's signature tune? Business Line, 27 July

Charantimath, P.M. (2011). Amway / Case Study. Published in Total Quality Management, Second Edition, 117

Chapple, W. \& Moon, J. (2005). Corporate Social Responsibility in Asia: A Seven-Country Study of CSR Web Site Reporting, Business \& Society, Vol. 44, No. 4, 415-41

Choueke, M. (2009). Presentation is the lifeblood of CSR. Marketing Week, London

Chow, W.S., Chen, Y. (2012). Corporate sustainable development. Testing a new scale based on the mainland Chinese context. J. Bus. Ethics 105, 519-533

Christensen, J. \& Murphy, R. (2004). The Social Irresponsibility of Corporate Tax Avoidance: Taking CSR to the Bottom Line. Development, Vol. 47, No. 3, 37-44

Christian Aid (2004). Behind the Mask: The Real Face of Corporate Social Responsibility. London: Christian Aid

Chuhan-Pole, P., Dabalen, A.L. and Land, B.C. (2017). Mining in Africa: Are Local Communities Better Off? Africa Development Forum Series. Washington, DC: World Bank

Clarkson, M. B. E. (1995). A stakeholder framework for analysing and evaluating corporate social performance. Academy of Management Review, Vol. 20, 92-117

Connelly, J. T. \& Limpaphayom, P. (2004). Environmental Reporting and Firm Performance: Evidence from Thailand'. Journal of Corporate Citizenship, Vol. 13, 137- 49

Correa, A. J. A. (1998). Strategic Proactivity and Firm Approach to the Natural Environment. Academy of Management Journal, Vol. 41, No. 5, 556-567

Cottrill \& Melville, T. (1990). Corporate social responsibility and the marketplace. Journal of Business Ethics, Vol. 9, 723-729

Crane, A. \& Matten, D. (2004). Business Ethics: A European Perspective - Managing Corporate Citizenship and Sustainability in the Age of Globalization. Oxford, Oxford University Press

Crane, A. \& Matten, D. (2007a). Business Ethics, 2nd Edn. Oxford: Oxford University Press

Crane, A., McWilliams, A., Matten, D., Moon, J. \& Siegel, D. S. (2008). The Oxford Handbook of Corporate Social Responsibility. $1^{\text {st }}$ Edn. Oxford University Press

Creswell, J. W. (2003). Research design: Qualitative, quantitative, and mixed methods approaches (2nd ed). Thousand Oaks, CA: Sage Publications

Creswell, J.W., (2007). Qualitative inquiry and research design: Choosing among five traditions ( $2^{\text {nd }}$ ed.). Thousand Oaks, CA: Sage 
Cropley, A. J., (2019). Qualitative research methods: A practice-oriented introduction for students of psychology and education ( $2^{\text {nd }}$ ed.). Riga, Latvia: Zinātne

Crotty, M. (1998). The Foundations of Social Research. London: Sage

Dahlsrud A, (2006). How Corporate Social Responsibility is defined: An Analysis of 37 Definitions. Corporate Social Responsibility and Environmental Management, Vol. 15, No. 1, 1-13

Damodar, S.K. (2016). Lesvos Island UNESCO Global Geopark, Greece- Systems Thinking on Sustainable Value. A Master's thesis submitted to Lahti University of Applied Sciences, Finland

Damodar, S. K. \& Aarrevaara, Eeva (2016). Corporate Social Responsibility \& Sustainable Development Initiatives in the Indian Corporate Sector. Article presented in the 'Smart Cities in Smart Regions 2016 Conference, Lahti, Finland

Damodaran (2001). Utilitarian, managerial and relational theories of corporate social responsibility. International Journal of Management Reviews, Vol, 9, No. 4, 347-373

Davis, K. (1960). Can Business Afford to Ignore Social Responsibilities? California Management Review, Vol. 2, No. 3, 70-76

Davis, K. \& Blomstrom, R. L. (1966). Business and its environment. New York: McGraw-Hill

Davis, K. \& Frederick, W. C. (1985_. Business and Society. McGraw-Hill, Singapore

Dawson, C. (2007). A practical guide to research methods ( $3^{\text {rd }}$ ed.). Published by How to Content, OX:UK

Day, G. S. \& Wensley, R. (1988). Assessing Advantage: A framework for diagnosing competitive superiority. Journal of Marketing, Vol. 52, No. 45- 57

Deegan (2002). An analysis of Islamic CSR concept and the opinions of Malaysian managers. Management of Environmental Quality: An International Journal, Vol. 20, Issue 3, pp. 1477-7835

Department of Public Enterprises (2007). Mid-Year Review of Central Public Sector Enterprises for 2006-2007, New Delhi. Ministry of Heavy Industries and Public Sector Enterprises. Government of India

De Oliveira, J. A. P. (2006). Corporate Citizenship in Latin America: New Challenges to Business. Journal of Corporate Citizenship, Vol. 21, 17-20

De Santis, L., \& Ugarriza, D.N. (2000). The concept of theme as used in qualitative research. Western Journal of Nursing Research, 22(3), 351-372

Diara, M. et al. (2004). Corporate Social Responsibility and Public- Private Partnership: The Case of the Academy for Educational Development and Exxon-Mobil. Development, Vol. 47, Issue 3, pp. 69-77

Dicken, P. (2003). Global Shift: Reshaping the Global Economic Map in the 21st Century. London: Guilford Publications Inc.

Dierickx, I. \& Cool, K. (1989). Asset Stock Accumulation and Sustainability of Competitive Advantage. Management Science, Vol. 35, Issue 12, pp. 1504-1513

Dolan, C. S. \& Opondo, M. (2005). Seeking Common Ground: Multi-stakeholder Processes in Kenya's Cut Flower Industry. Journal of Corporate Citizenship, Vol. 18, pp. 87-98 
Donaldson, L. (1990). The ethereal hand: Organizational economics and management theory. Academy of Management Review 15(3):369-381

Donaldson \& Dunfee (1999). Ties that bind: A Social Contract Approach to Business Ethics. Boston: Harvard Business School

Donaldson, T. (1996). Values in tension. Ethics away from home. Harvard Business Review. September - October, 48-62

Donaldson, T. \& Preston, Lee E. (1995). The Stakeholder Theory of the Corporation: Concepts, Evidence and Implications. Academy of Management Review, Vol. 20, pp.65-91

Drucker, Peter F. (1984). The New Meaning of Corporate Social Responsibility. California Management Review, Winter, Vol. XXVI, No. 2, pp. 54-62

Dul, J. \& Hak. T. (2008). Case study methodology in business research. Published by Elsevier Limited, MA, USA

Economist (2005). The Good Company. The Economist, Vol. 374, Issue 8410, p. 11

Edenkamp, P. (2002). Insights into how consumers are thinking, how they are acting and why? Brandweek, Vol. 43, Issue 36, pp. $16-20$

Edwards, T. et al. (2004). Value Creation and the UK Economy: A Review of Strategic Options, International Journal of Management Reviews, Vol. 5/6, pp. 3/4, pp. 191-213

Egels, N. (2005). CSR in Electrification of Rural Africa: The Case of ABB in Tanzania. Journal of Corporate Citizenship, pp. $75-85$

Eilbirt, H. \& Parket, I. R. (1973). The current status of corporate social responsibility. Business Horizons, Vol. 16, No. 4, pp. 5-14

Etzoini, A. (1964). Modern Organizations. Englewood Cliffs, NJ: Prentice-Hall

Epstein, E. M. (1987). The Corporate Social Policy Process: Beyond Business Ethics, Corporate Social Responsibility, and Corporate Social Responsiveness. California Management Review, Vol. 29, pp. 99-114

European Commission (2001). Green Paper. Promoting a Europe Framework for Corporate Social Responsibility. Brussels: COM (2001) 366 final

European Commission (2002). Corporate Social Responsibility: A Business Contribution to Sustainable Development. Luxemburg: Office for Official Publications of the European Communities

Evan, W. M. \& Freeman, R.E. (1988). A Stakeholder Theory of the Modern Corporation: Kantian Capitalism, in "Ethical Theory and Business," 3rd ed., eds. T.L. Beauchamp and N.E. Bowie. Englewood Cliffs, New Jersey: Prentice-Hall, 97-106

Fernando, M. (2007). Corporate Social Responsibility in the Wake of the Asian Tsunami: A Comparative Case Study of Two Sri Lankan Companies'. European Management Journal, Vol. 25, No. 1, pp. 1-10

Fig, D. (2005). Manufacturing Amnesia: Corporate Social Responsibility in South Africa. International Affairs, Vol. 81 , No. 3, pp. 599-617 
Fombrun, C. \& Shanley, M. (1990). What's in a Name? Reputation Building and Corporate Strategy. Academy of Management Journal, Vol. 33, No. 2, pp. 233-258

Foo, S. L. \& Tan, M. S. (1988). A comparative study of social responsibility reporting in Malaysia and Singapore. Singapore Accountant, pp. 12-15

Fourie, A. \& Eloff, T. (2005). The Case for Collective Business Action to Achieve Systems Change: Exploring the Contributions Made by the Private Sector to the Social, Economic and Political Transformation Process in South Africa. Journal of Corporate Citizenship, Vol. 18, pp. 39-48

Fox, T. (2004). Corporate Social Responsibility and Development. In Quest of an Agenda Development, Vol. 47, No. 3, pp. 29-36

Freeman, R. E. (1984). Strategic Management: A Stakeholder Approach. Boston: Pitman/Ballinger

Freeman, R. E. \& Reed, D. L. (1983). Stockholders and stakeholders: A new perspective on corporate governance. California Management Review, 25 (3): 93-94

Freeman, R.E., Harrison, J. \& Wicks, A. (2007). Managing for stakeholders (New Haven: Yale University Press

Friedman, M. (1962). Capitalism and Freedom. Chicago: University of Chicago Press, 133

Friedman, M. (1967). Capitalism and Freedom. Chicago: The University of Chicago Press.

Friedman, M. (1970). The social responsibility of business is to increase its profits. New York Times Magazine, pp. 122-126. Published by The New York Times Company on September 13

Friedman, M. (1996). The Social Responsibility of Business is to increase profit, In Dusuki, A.W., What Does Islam Say About Corporate Social Responsibility?', Review of Islamic Economics, Vol. 12, No 1

Fry, L. W., Keim, G. D. \& Meiners, R. E. (1982). Corporate Contributions: Altruistic or for Profit? The Academy of Management Journal, Vol. 25, No. 1, pp. 94-106

Frynas, J. G. (2006). Corporate Social Responsibility in Emerging Economies. Journal of Corporate Citizenship, Vol. 24, pp. 16-19

Gabriel, P. P. (1972). MNCs in the Third World: Is Conflict Unavoidable? Harvard Business Review. Vol. 50, No. 4, pp. 93-102

Garriga, E. \& Melé, D. (2004). Corporate Social Responsibility Theories: Mapping the Territory. Journal of Business Ethics, Vol. 53, No. 1-2, pp. 51-71

Georges, Aoun (2007). CSR programmes in multinational companies facing a local environment: Case of the Middle East". Paper presented in ITESO (Guadalajara, Mexico) at the IAJBS 13th International Forum in June 2007

Gilbert, T., Komaran, R. (2006). Perceptions of Corporate Social Responsibility: An empirical study in Singapore. Submitted for the Thirteenth Annual International Conference on Advances in Management

Gouldner, A. W. (1960). The Norm of Reciprocity: A Preliminary Statement. American Sociological Review, Vol. 25, Vo. 2, pp. $161-178$

Goyal, A. (2006). Corporate Social Responsibility as a Signaling Device for Foreign Direct Investment. Journal of Corporate Citizenship, Vol. 13, no. 1, pp. 145-63 
Gray, R. (2001). Responsibility up the agenda. Marketing, London, pp. 39

Greenfield, W. M. (2004). In the name of Corporate Social Responsibility. Business Horizons, Vol. 47, pp. 19-28 Griffin, J. J. \& Mahon, J. F. 1997. The Corporate Social Performance and Corporate Financial Performance Debate. Business and Society, Vol. 36, No. 1, pp. 5-31

Griffin, J. J. (2000). Corporate Social Performance: Research directions for the 21st Century. Business \& Society, Vol. 39, No. 4, pp. 479-491

Gulbrandsen, L. H. (2006). Creating Markets for Eco-labelling: Are consumers insignificant?International Journal of Consumer Studies, Vol. 30, No. 5, pp. 477-489

Hart, C. (1998). Doing a literature review: Releasing the social science research imagination. London, Sage Publication

Hart, S. L. (1995). A Natural Resource Based View of the Firm. Published in the Academy of Management Review, Vol. 20, No. 4, pp. 986-1014

Haslam, P. A. (2007). The Corporate Social Responsibility System in Latin America and the Caribbean, in Crane and Matten

Hair, J. F. et al. (2003). Essentials of Business Research Methods. John Wiley and Sons, NY

Hamann, R. et al. (2005). Local Governance as a Complex System: Lessons from Mining in South Africa, Mali and Zambia. Journal of Corporate Citizenship, Vol. 18, pp. 61-73

Hardcourt, W. (2004). Editorial: Is CSR Rewriting Development? Development, Vol. 47, No. 3, pp. 1-2

Heslin, P. A. \& Ochoa, J. D. (2008). Understanding and developing strategic corporate social responsibility. Organizational Dynamics, Vol. 27, No. 2, pp. 125-144

Hillenbrand, C. \& Money, K. (2007). Corporate responsibility and corporate reputation: Two separate concepts or two sides of the same coin? Corporate Reputation Review, Vol. 10, No. 4, pp. 261-277

Hillman, A. \& Keim, G. (2001). Shareholder value, stakeholder management, and social issues: What's the bottom line? Strategic Management Journal, Vol. 22, pp.125-139

Hoeffler, S. \& Keller, K. L. (2002). Building Brand Equity through Corporate Societal Marketing. Journal of Public Policy \& Marketing, Vol. 21, No. 1, pp. 78-89

Hoffman, A. J. (2005). Climate Change Strategy: The Business Logic Behind Voluntary Greenhouse Gas Reductions. California Management Review, Vol. 47, No. 3, pp. 21-46

Henderson, D. (2001). Misguided Virtue: False Notions of Corporate Social Responsibility. Institute for Economic Affairs, London

Hrebiniak, L. G. \& Joyce, W. F. (1985). Organizational Adaptation: Strategic Choice and Environmental Determinism. Administrative Science Quarterly, Vol. 30, No. 3, pp. 336-349

Hung, W. T. \& Ramasamy, B. (2004). A comparative analysis of corporate social responsibility awareness, Malaysian and Singaporean corporations. Journal of Corporate Citizenship, Vol. 13, pp. 109-123 
Hunt, S. D. (2000). A General Theory of Competition. Sage Publications: Thousand Oaks, CA

Husted, B. W. \& Allen, D. B. (2006). Corporate Social Responsibility in the Multinational Enterprise: Strategic and Institutional Approaches. Journal of International Business Studies, Vol. 37, No. 6, pp. 838-849

Husted, B. W. \& Allen, D. B. (2007). Corporate social strategy in multinational enterprises: Antecedents and value creation. Journal of Business Ethics, Vol. 74, pp. 345-361

Husted, B. W. \& Allen, D. B. (2007). Corporate social responsibility and value creation among large firms: Lessons from the Spanish experience. Long Range Planning: International Journal of Strategic Management, Vol. 40, No. 6, pp. 594-610

Husted, B. W. \& Allen, D. B. (2009). Strategic Corporate Social Responsibility and Value Creation: A Study of Multinational Enterprises in Mexico. Management International Review Vol. 49, No. 6, pp. 781-799

Idowu, A. (2014). Corporate Social Responsibility in Nigerian Banking Industry: When will the Lip-Service Games End? Journal of Economic and Sustainable Development. Vol. 5, No. 22, pp. 21-26

IoD (1992). King Report on Corporate Governance in South Africa. Johannesburg: Institute of Directors in Southern Africa

IoD (2002). King Report on Corporate Governance in South Africa. Johannesburg: Institute of Directors in Southern Africa

Ite, U. E. (2004). Multinationals and Corporate Social Responsibility in Developing Countries: A Case Study of Nigeria. Corporate Social Responsibility and Environmental Management, Vol. 11, No. 1, pp. 1-11

Jacobides, M. G., Knudsen, T. \& Augier, M. (2006). Benefiting from Innovation: Value Creation, Value Appropriation and the role of Industry Architectures. Research Policy, Vol. 35, No. 8, pp. $1200-1221$

Jari, K. et al. (2003). Social responsibility in environmental marketing planning. European Journal of Marketing, Vol. 37, No. $5 / 6$, pp. $848-871$

Jenkins, R. (2005). Globalization, Corporate Social Responsibility and Poverty. International Affairs, Vol. 81, No. 3 , pp. $525-40$

Jensen, M. C. (2002). Value maximization, stakeholder theory, and the corporate objective function. Business Ethics Quarterly, Vol. 12, pp. $235-256$

John, K. (2003). Differentiating stakeholder theories. Journal of Business Ethics, Dordrecht, Vol. 46, No. 1, pp. 71

Johnson, G. \& Scholes, K. (2002). Exploring Corporate Strategy. Essex: Pearson Education Limited

Johnson, H. H. (2003). Does It Pay to Be Good? Social Responsibility and Financial Performance. Business Horizons, Vol. 46, pp. 34-40

Johnson, H. L. (1971). Business in contemporary society: Framework and issues. Belmont, CA: Wadsworth

Johnson, M. (2004). Marks \& Spencer Implements an Ethical Sourcing Program for its Global Supply Chain. Journal of Organizational Excellence, Vol. 23, No. 2, pp. 3-16

Joyner, B. E. \& Payne, D. (2002). Evolution and implementation: A study of Values, Business ethics and Corporate social responsibility. Journal of Business Ethics, Vol. 41, No. 4, pp. 297-311 
Juholin, E. (2004). For business or for the good of all? A Finnish approach to Corporate Social Responsibility.

Corporate Governance, Vol. 4, No. 3, pp. 20-32

Kanter, R. M. (1999). From Spare Change to Real Change. Harvard Business Review, Vol. 77, No. 3, pp. 122-132

Kapelus, P. (2002). Mining, Corporate Social Responsibility and the Case of Rio Tinto, Richards Bay Minerals and the Mbonambi. Journal of Business Ethics, Vol. 39, pp. 275-96

Kaufman, A. et al. (2004). 'Implementing Voluntary Labour Standards and Codes of Conduct in the Thai Garment Industry'. Journal of Corporate Citizenship, Vol. 13, pp. 91-9

Keeler, D. (2002). Spread the love and make it pay. Global Finance, Vol. 16, No. 5, pp. 20-25

Khaliq, H. S. (2004). Eliminating Child Labour from the Sialkot Soccer Ball Industry: Two Industry-Led Approaches. Journal of Corporate Citizenship, Vol. 13, pp. 101-7

Khanna, V. (2004a). It's everybody's business. The Business Times Singapore [Retrieved: 15.09.2011]. Available at: Factiva database

Khanna, V. (2004b). Singapore companies heeding the CSR call. The Business Times Singapore [Retrieved: 25.09.2011]. Available at: Factiva database

Khoo, H. H. \& Tan, K. C. (2002). Using the Australian Business Excellence Framework to Achieve Sustainable Business Excellence. Corporate Social Responsibility and Environmental Management, Vol. 9, No. 4, pp. 196-205

Kimery, K. M. \& Rinehart, S. M. (1998). Markets and constituencies: An alternative view of the marketing concept. Journal of Business Research, Vol. 43, No. 3, pp.117-24

King, D. A. (2004). The Scientific Impact of Nations: What Different Countries Get for Their Research Spending. Nature, Vol. 430, pp. 311-316

Knights, D. (2002). Writing Organizational Analysis into Focault. Organization, Vol. 9, No. 4, pp. 575-593

Kolk, A. \& Tulder, V. R. (2002). Child Labour and Multinational Conduct: A Comparison of International Business and Stakeholder Codes. Journal of Business Ethics, Vol. 36, pp.291-301

Korten, D. (2001). When corporations rule the world. Kumarian Press, Bloomfield, CT

Kotler, P. \& Lee, N. (2005). Corporate Social Responsibility: Doing the mostgood for your company and your cause. John Wiley \& Sons, Inc., Hoboken, New Jersey

Krishna, C. G. (1992). Corporate Social Responsibility in India. Mittal Publications, New Delhi

Krishnamurthy, S. et al. (2007). Corporate Social Responsibility and Public Relations: Perceptions and Practices in Singapore. Paper submitted to the 14th International Public Relations Symposium, Bled, Slovenia, July 3-5, 2007

Lantos, G. (2002). The Ethicality of Altruistic Corporate Social Responsibility. Journal of Consumer Marketing, Vol.19, No. 3, pp. 205-230

Lawrence, A. T., Weber, J. \& Post, J. E. (2005). Business and Society: Stakeholders, Ethics, Public Policy. McGrawHill 
Lee, B., Jeanne, M. \& Logsdon (1996). Corporate Social Responsibility Pays Off, Long Range Planning, Vol. 29, no. 4, pp. 437-596

Lee, K.H. \& Saen, R.F. (2012). Measuring corporate sustainability management: A data envelopment analysis approach. Int. J. of Prod. Econ. 140, 219-226

Lee, N. \& Lings, I. (2008). Doing Business Research, A Guide to Theory and Practice. London: Sage

Levy, D. \& Kaplan, R. (2008). Corporate Social Responsibility and Theories of Global Governance: Strategic Contestation in Global Issue Arenas, in: The Oxford Handbook of CSR, Oxford: Oxford University Press. pp. 432-451

Lindgreen, A. et al. (2009). The Supporting Function of Marketing in Corporate Social Responsibility. Corporate Reputation Review, Vol. 12, No. 2, pp.120-24

Lo, S. F. \& Shue, H. J. (2007). Is corporate sustainability a value-increasing strategy for business? Corporate Governance, Vol. 15, No. 2, pp 345-358

Logsdon, J. M. et al. (2006). Corporate Social Responsibility in Large Mexican Firms. Journal of Corporate Citizenship, Vol. 21, pp. 51-60

London, T. \& Hart, S. L. (2004). Reinventing Strategies for Emerging Markets: Beyond the Transnational Model. Journal of International Business Studies, Vol. 35, No. 5, pp. 350-70

López- Morales, J.S., Ortega- Ridaura, I. \& Ortis-Betancourt, I. (2017). Strategies of Corporate Social Responsibility in Latin America- A content analysis in the extractive industry. Published in the AD-MINISTER, No.31, July-Dec. Universidad EAFIT, Medellin, Colombia

Luce, R. A. et al. (2001). Good Deeds and Misdeeds: A Medicated Model of the Effect of Corporate Social Performance on Organizational Attractiveness. Business \& Society, Vol. 40, No. 4, pp. 97-415

Luken, R. \& Stares, R. (2005). Small Business Responsibility in Developing Countries: A Threat or an Opportunity? Business Strategy and the Environment, Vol. 14, pp. 38-53

Luo, X. \& Bhattacharya, C. B. (2006). Corporate Social Responsibility, Customer Satisfaction and Market Value. Journal of Marketing, Vol. 70, pp. 1-18

Lyles, M. A. (1985). Strategic Problems: How to Identify Them, In L. Fahey Ed, The Strategic \& Planning Management Reader, Prentice Hall: Englewood Cliffs, NJ

Macleod, S. (2001). Why worry about CSR? Strategic Communication Management, Vol. 5, No. 5, pp. 8-9

Maignan, I. \& Ferrel, O. C. (2004). Corporate Social Responsibility and Marketing: An Integrative Framework. Journal of the Academy of Marketing Science, Vol. 32, No. 1, pp. 3-19

Maignan, I. \& Ralston, D. A. (2002). Corporate Social Responsibility in Europe and the U.S.: insight from businesses self-perceptions. Journal of International Business Studies, Vol. 33, No. 3, pp. 497-514

Malan, D. (2005). Corporate Citizens, Colonialists, Tourists or Activists? Ethical Challenges facing South African Corporations in Africa. Journal of Corporate Citizenship, Vol. 18, pp. 49-60

Managi, S., Opalauch, J.J., Jin, D. \& Grigalunas, T. (2005). “Environmental regulations and technological change in the offshore oil and gas industry". Land Economics 81(2), 303-319 
Manne, H. G. \& Wallich, H. C. (1972). The Modern Corporation and Social Responsibility. Washington, DC: American Enterprise Institute for Public Policy Research

Margolis \& Walsh (2001). A corporate social performance-corporate financial performance behavioral model for consumers. The Academy of Management Review Archive, Vol. 31, No. 3, pp. 540-558

Maskrey, A. (1989). Disaster Mitigation: A Community Based Approach. Development Guidelines, no.3, Oxford: Oxfam

Maslow, A. H. (1943). A Theory of Human Motivation. Published in Psychological Review 50, 370-396

Matten, D. \& Crane, A. (2005). Corporate Citizenship: Toward an Extended Theoretical Conceptualization. Academy of Management Review, Vol. 30, No. 1, pp. 166-79

Matten, D. \& Moon, J. (2008). Implicit and Explicit CSR: A Conceptual Framework for a Comparative Understanding of Corporate Social Responsibility. Academy of Management Review, Vol. 33, No. 2, pp. 404-424

Mazur, E. (2006). Environmental Compliance and Enforcement in India: Rapid Assessment. A report produced jointly by OECD Programme for Environmental Cooperation with Asian Environmental Compliance and Enforcement Network (AECEN) and presented at AECEN Annual forum in Hanoi, Vietnam on 4-5 December.

McAlister, D. \& Ferrell, L. (2002). The role of strategic corporate philanthropy in marketing strategy. European Journal of Marketing, Vol. 36, No. 5, pp. 689-708

McCullough, M. E. et al. (2001). Is gratitude a moral affect? Psychological Bulletin, Vol. 127, No. 2, pp. 249-266

McCullough, M. E. et al. (2002). The Grateful Disposition: A Conceptual and Empirical Topography, Journal of Personality and Social Psychology, Vol. 82, No. 1, pp. 112-127

McGuire, J. W. (1963). Business and Society. New York. McGraw-Hill

McGuire, J. W. (1969). The changing nature of business responsibilities. Journal of Risk and Insurance. Vol.36, pp $55-61$

McKinnon, J. (1988). Validity and Reliability in Field Research: Some Strategies and Tactics. Accounting, Auditing and Accountability Journal, Vol. 1, No. 1, pp. 34-54

McWilliams, A. \& Siegel, D. (2001). Corporate Social Responsibility: A Theory of the Firm Perspective. The Academic Management Review, Vol. 26, No.1, pp.117-127

McWilliams, A. et al. (2001). Profit Maximizing Corporate Social Responsibility. Academy of Management Review, Vol.26, pp. 504-505

McWilliams, A. et al. (2006). Corporate Social Responsibility: Strategic Implications. Journal of Management Studies, Vol. 43, No. 1, pp. 1-18

Mehra, P. (2004). Intel outside. Praxix, Business Line, December, pp. 44-46

Meznar, M. B. \& Nigh, D. (1995). Buffer or Bridge? Environmental and Organizational Determinants of Public Affairs Activities in American Firms. Academy of Management Journal, Vol. 38, No. 4, pp. 975-996

Michael, P. E. et al. (2006). Strategy \& Society: The Link between Competitive Advantage and Corporate Social Responsibility. Harvard Business Review, December, Vol. 84, No. 12, pp-56-68 
Miles, M. P. \& Covin, J. G. (2000). Environmental marketing: A source of reputational, competitive, and financial advantage. Journal of Business Ethics, Vol. 23, pp. 299-311

Mintzberg, H. (1988). Opening up the definition of strategy, in Quinn, B., Mintzberg, H. \& James, R. M., The Strategy Process, Prentice-Hall, Englewood Cliffs, NJ

Mintzberg, H., Lampel, J. B., Quinn, J. B. \& Ghoshal, S. (2002). The Strategy Process: Concepts, Contexts and Cases, Prentice-Hall: Englewood Cliffs, NJ

Mitchell, R. K., Agle, B. R. \& Wood, D. J. (1997). Toward a theory of stakeholder identification and salience: Defining the principle of who and what really counts. Academy of Management Review, Vol. 22, No. 4, pp. 853-887

Moir, L. (2001). What do we mean by Corporate Social Responsibility? Corporate Governance: International Journal of Business in Society, Vol. 1, No. 2, pp. 16-22

Moon, Crane, A. \& Matten, D. (2005). Can Corporations be Citizens? Corporate Citizenship as a Metaphor for Business Participation in Society. Business Ethics Quarterly, Vol. 15, No. 3, pp. 427-51

Moon, J. (2002a). Business Social Responsibility and New Governance. Government and Opposition, Vol. 37, No. 3, pp. $385-408$

Morales, A. C. (2005). Giving Firms an 'E' for Effort: Consumer Responses to High-Effort Firms. Journal of Consumer Research, Vol. 31, No. 4, pp. 806-812

Moran, P. \& Ghoshal, S. (1999). Markets, Firms and the Process of Economic Development. Academy of Management Review, Vol. 24, No. 3, pp. 390-412

Murray, K. \& Vogel, C. (1997). Using a hierarchy-of-effects approach to gauge the effectiveness of corporate social responsibility to generate goodwill toward the firm: Financial versus Non-financial impacts. Journal of Business Research, Vol. 38, pp. 141-159

Mwaura, K. (2004). Corporate Citizenship: The Changing Legal Perspective in Kenya. Interdisciplinary CSR Research Conference, Nottingham, International Centre for Corporate Social Responsibility

Nelson, J. (2003). Economic Multipliers: Revisiting the Core Responsibility and Contribution of Business to Development. London: International Business Leaders Forum (IBLF)

Nelson, J. (2004). Corporate citizenship in a global world. Corporate Social Responsibility Initiative Working, Cambridge, MA: John F. Kennedy School of Government, Harvard University. pp. 13

Nielsen, M. E. (2005). The Politics of Corporate Responsibility and Child Labour in the Bangladeshi Garment Industry. International Affairs, Vol. 81, No. 3, pp. 559-80

Newell (2005). Citizenship, Accountability and Community: The Limits of the CSR Agenda. International Affairs, Vol. 81 , No. 3, pp. 541-57

Newell, P. (2001). Managing Multinationals: The Governance of Investment for the Environment. Journal of International Development, Vol. 13, pp. 907-19

Newell \& Muro, A. (2006). Corporate Social and Environmental Responsibility in Argentina: The Evolution of an Agenda. Journal of Corporate Citizenship, Vol. 24, pp. 49-68 
Normann, R. \& Ramirez, R. (1993). From value chain to value constellation: Designing interactive strategy. Harvard Business Review, Vol. 71, pp. 65-65

Norton, S. D. (2007). The natural environment as a salient stakeholder: Non-anthropocentrism, ecosystem stability and the financial market'. Business Ethics, A European Review, Vol. 16, No. 4, pp. 387-402

Novak, M. (1996). Business as a Calling: Work and the Examined Life. The Free Press, New York, NY

Olivelle (2013). King, Governance, and Law in Ancient India. Kautilya's Arthasastra. Published by Oxford University Press

Orlitzky, M. et al. (2003). Corporate Social and Financial Performance: A Meta-analysis. Organization Studies, Vol. 24, pp. 403-411

Ostlund, L. E. (1977). Attitudes of Managers towards Corporate Social Responsibility. California Management Review, Vol. 19, No. 4, pp. 35-49

Paul, A. (2007). Companies of a lesser God? 4Ps Business and Marketing, December, 58-59

Pedersen, E. R. \& Huniche, M. (2006). Corporate Citizenship in Developing Countries. Copenhagen: Copenhagen Business School Press

Pedro, O. et al. (2013). The State of the Poor: Where are The Poor? Where is Extreme Poverty Harder to End, and What is The Current Profile of the World's Poor? Published in Poverty Reduction and Economic Management Network (PREM), World Bank dated October 2013, Number 125

Perrini, F., Russo, A. \& Tencati, A. (2007). CSR Strategies of SMEs and Large firms: Evidence from Italy, Journal of Business Ethics, Vol. 74, pp. 285-300

Pikston, T. S. \& Carroll, A. (1996). A Retrospective Examination of CSR Orientations: Have they changed? Journal of Business Ethics. Vol. 13, pp. 157-169

Planken, B. et al. (2010). Corporate Social Responsibility communication in the Indian context. Journal of Indian Business Research, Vol. 2, No. 1

Polonsky, M. J. (1996). Stakeholder management and the stakeholder matrix: Potential strategic marketing tools. Journal of Marketing-Focused Management, Vol. 1, No. 1, pp. 209-29

Porter, M. E. \& Kramer, M. R. (2006). Strategy and Society: The link between Competitive Advantage and Corporate Social Responsibility. Harvard Business Review

Porter, M. E. \& Linde, C. V. (1995). Green and Competitive: Ending the Stalemate. Harvard Business Review, Vol. 9, No. 4, pp. 120-134

Porter, M. E. \& Linde, C. V. (1995). Toward a New Conception of the Environment-Competitiveness Relationship. Journal of Economic Perspectives, Vol. 9, No. 4, pp. 97-118

Post, J. E. et al. (2002). Managing the Extended Enterprise: The New Stakeholder View. California Management Review, Vol. 45, No.1, pp. 6-28

Prahalad, C. K. \& Hammond, A. (2002). Serving the World's Poor, Profitably. Harvard Business Review, Vol. 80, No. 9, pp. 48-57 
Quinn, J. B. (1980). Strategies for Change: Logical Incrementalism. Richard D. Irwin: Homewood, IL

Rangan, V. K. et al. (2007). Business Solutions for the Global Poor: Creating Social and Economic Value. John Wiley \& Sons, San Francisco

Rashid, Z. A. \& Ibrahim, S. (2002). Executive and Management Attitudes towards Corporate Social Responsibility in Malaysia. Corporate Governance, Vol. 2, No. 4, pp. 10-16

Ravallion, M., Chen, S. \& Sangraula, P. (2008). Dollar a day revisited. Policy Research Working Paper 4620. World Bank, May

Reed, D. (2002). Corporate Governance Reforms in Developing Countries. Journal of Business Ethics, Vol. 37, pp. 223-47

Ridenour, C.S. \& Newman, I. (2008). Mixed Methods Research- Exploring the interactive continuum. Southern Illinois University, Carbondale, USA

Riessman, C. K. (1993). Narrative analysis. Newbury Park, CA: Sage.

Roberts, P. W. \& Dowling, G. R. (2002). Corporate Reputation and Sustained Superior Financial Performance. Strategic Management Journal, Vol. 23, No. 12, pp. 1077-1093

Robin et al. (1987). Social Responsibility, Ethics and Marketing Strategy: Closing the Gap Between Concept and Application. Journal of Marketing, Vol. 51

Rogert, L. \& Martin (2002). The Virtue Matrix, Calculating the Return on Corporate Responsibility. Harvard Business Review, pp. 69-75

Roussouw, G. J. et al. (2002). Corporate Governance in South Africa. Journal of Business Ethics, Vol. 37, No. 3, pp. 289-302

Ruf, B. M., Muralidhar, K. \& Brown, R. M. (2001). An Empirical Investigation of the Relationship between Change in Corporate Social Performance and Financial Performance: A Stakeholder Theory Perspective. Journal of Business Ethics, Vol. 32, No. 2, pp. 143-156

Rumelt, R. P. (1980). The evaluation of business strategy, in Glueck, W. F., Business Policy and Strategic Management, 3rd Edn, McGraw-Hill: New York

Rummel, R.J. (1970). Applied factor analysis. Evanston, IL: Northwestern University Press.

Saldana, J. (2013).The coding manual for qualitative researchers. Los Angeles, CA: SAGE Publications.

Saunders, M. Lewis, P. \& Thornhill, A. (2000). Research Methods for Business Students. Pearson Education Limited

Saunders, M. Lewis, P. \& Thornhill, A. (2003). Research Methods for Business Students, 3rd ed., Prentice Hall: London

Saunders, M., Lewis, P. \& Thornhill, A. (2009). Research Methods for Business Students, 5thEd, Essex: Pearson Education Limited

Schlein \& Lisa (2008). China's Melamine Milk Crisis Creates Crisis of Confidence. Voice of America 
Schmidheiny, S. (2006). A View of Corporate Citizenship in Latin America. Journal of Corporate Citizenship, Vol. 21, pp. 21-4

Schrage, E. J. \& Ewing, A. P. (2005). The Cocoa Industry and Child Labour. Journal of Corporate Citizenship, Vol. 18, pp. 99-112

Schrage, M. (2007). The Myth of Commoditization. MIT Sloan Management Review, Vol. 48, No. 2, pp.10-14

Schumpeter, J. A. (1934). The Theory of Economic Development. Harvard University Press: Cambridge, MA

Seal, C., Gobo, G. \& Gubrium, J.F., et al. (2007). Qualitative Research Practice:Concise Paperback Edition. 1th edition, SAGE Publications, London,UK

Secchi, D. (2007). Utilitarian, Managerial and Relational Theories of Corporate Social Responsibility'. International Journal of Management Reviews, Volume 9, Issue 4, pp. 347-373

Sekaran, U. (2003). Research Methods for Business, New York, NY: John Wiley and Sons

Sen, S. (2006). The Role of Corporate Social Responsibility in Strengthening Multiple Stakeholder Relationships: A Field Experiment, Journal of the Academy of Marketing Science, Vol. 34

Sen, S. \& Bhattacharya, C. B. (2001). Does doing good always lead to doing better? Consumer reactions to corporate social responsibility. Journal of Marketing Research, Vol. 38, No. 2, pp. 225-243

Sharma, A. (2006). Bringing Good things to People. Business Standard, 21 March

Sheth, J. N. \& Mittal, B. (2004). Customer Behavior: A Managerial Perspective, 2nd Edition. Ohio: Thompson South-Western

Shocker, A. D. \& Sethi, S. P. (1974). An approach to incorporating social preference in developing corporate action strategies, in Sethi, A. D., The unstable ground: Corporate social policy in a dynamic society. Los Angeles: Melville Publishing, pp.67-80

Shrivastava, P. (1995). Industrial/Environmental Crises and Corporate Social Responsibility. Journal of SocioEconomics, Vol. 24, No. 1, pp. 211-27

Silberhorn, D. \& Warren, R. C. (2007). Defining corporate social responsibility: A view from big companies in Germany and the U.K. European Business Review, Vol. 19, No. 5, pp. 352-372

Simoes, C., Sebastiani, R. (2017). The nature of the relationahip between corporate identity and corporate sustainability: Evidence from the retail industry. Bus. Ethics. Quart. 27, 423-453

Simon, J. \& Burstein, P. (1985). Basic Research Methods in Social Science, Toronto: McGraw-Hill, Inc.

Smith, S. M., Thorpe, R. \& Jackson, P. (2008). Management Research. London, Sage

Srinivasan, S. (2007). Corporate Social Responsibility. The Financial Express. 15 June

Stanwick, P. A. \& Stanwick, S. D. (1998). The determinants of corporate social performance: An empirical examination. American Business Review, Vol. 16, No. 1, pp. 86-93

Statistical Outline of India (2009). Growth of public and private sector companies. Available at: Indian Business and Economy. Published by VK (India) Enterprises, New Delhi, p38 
Stoll, M. L. (2007). Backlash hits business ethics: Finding effective strategies for communicating the importance of corporate social responsibility. Journal of Business Ethics, Vol. 78, pp. 17-24

Stone, C. (1975). Where the Law Ends: The Social Control of Corporate Behavior. New York: Harper Collins

Stevens, et al. (1998). Systems Engineering, Coping with Complexity. Prentice Hall Europe 1998

Stevens, J.P. (1984). Outliers and Influential Datapoints in Regression analysis. Psychological Bulletin Vol.95, No.2, 334-344

Tashakkori, A. \& Teddlie, C. (2003). Handbook of Mixed Methods in Social \& Behavioral Research. Thousand Oaks, CA: Sage

Tesser, A. Gatewood, R. \& Driver, M. (1968). Some determinants of gratitude. Journal of Personality and Social Psychology, Vol. 9, No. 3, pp. 233-236

Thomas, A. S. \& Simerly, R. L. (1995). Internal Determinants of Corporate Social Performance: The Role of Top Managers. Academy of Management Best Papers Proceedings; 1995, pp. 411-415

Thompson, M. S. \& Thompson, S. (2006). Pricing in a Market without Apparent Horizontal Differentiation: Evidence from Web Listing Services. Economics of Innovation and New Technology, Vol. 15, No. 7, pp. 649-563

Thomsen, L. P. (2004). Towards a Critical Framework on Corporate Social and Environmental Responsibility in the South: The Case of Pakistan. Development, Vol. 47, No. 3, pp. 106-113

Thorelli, H. B. (1997). Musings on business game performance evaluation. Developments in Business Stimulations and Experiential Learning, Vol.24, pp.12-18

Tsang \& Eric, W. K. (1998). A longitudinal study of corporate social reporting in Singapore: The case of banking, food and beverages and hotel industries. Accounting, Auditing and Accountability Journal, Vol. 11, No. 5, pp. 624 635

Tuzzolino, F. \& Armandi, B. R. (1981). A Need-Hierarchy Framework for Assessing Corporate Social Responsibility. Academy of Management Review, Vol. 6, No. 1, pp. 21-28

UNCTAD (2007). The Universe of the Largest Transnational Corporations. UNCTAD Division on Investment, Technology and Enterprise Development, United Nations Office, Geneva

United Nations (2013). The Millennium Development Goals Report 2013. Published in United Nations, New York, June 2013

United Nations (2015). Addis Ababa Action Agenda of the Third International Conference on Financing for Development, 13-16 July. Addis Ababa, Ethiopia

United Nations Department of Public Information (2013). We can end poverty. The Millennium Development Goals Report 2013, United Nations

United Nations General Assembly (2005). 2005 World Summit Outcome, Resolution A/60/1, adopted by the General Assembly on 15 September [Retrieved: 24.11.2013].

Vackayil, J. (2007). CSR is the New Growth Mantra. Business Line 17 June 
Vara, P. E. (2006). Corporate Social Responsibility in Latin America. Journal of Corporate Citizenship, Vol. 21

Varadarajan, P. R. \& Menon, A. (1988). Cause-Related Marketing: A coalignment of marketing strategy and corporate philanthropy. Journal of Marketing, Vol. 52, pp. 58-72

Ven, B. (2008). An Ethical Framework for the Marketing of Corporate Social Responsibility. Journal of Business Ethics, Vol. 82, pp. 339-352

Visser, W. (2005). Corporate Citizenship in South Africa: A Review of Progress Since Democracy'. Journal of Corporate Citizenship, Vol. 18, pp. 29-38

Visser, W. (2006). Revisiting Carroll's CSR Pyramid: An African Perspective. In: Corporate Citizenship in a Development Perspective (pp29-56). Edited by Pedersen, Esben Rahbek \& Huniche, Mahad at Copenhagen: Copenhagen Business School Press

Visser, W. (2007b). Revisiting Carroll's CSR Pyramid, in Crane and Matten

Visser, W. \& Macintosh, A. (1998). A Short Review of the Historical Critique of Usury. Accounting, Business \& Financial History, Vol. 8, No. 2, pp. 175-89

Vivarta, V. \& Canela, G. (2006). Corporate Social Responsibility in Brazil: The Role of the Press as Watchdog. Journal of Corporate Citizenship, Vol. 21, pp. 95-106

Vives, A. (2006). Social and Environmental Responsibility in Small and Medium Enterprises in Latin America. Journal of Corporate Citizenship, Vol. 21, pp. 39-50

Von Hagen et al. (2010). Sustainable Sourcing in the Food Industry- Global Challenges and Practices. Published in Moderne Ernaehrung Heute, Official Journal of the Food Chemistry Institute of the Association of the German Confectionery Industry. Volume 4, p.1-9. October

Waddock, S. A. \& Graves, S. B. (1997). The Corporate Social Performance-Financial Performance Link. Strategic Management Journal, Vol. 18, No. 4, pp. 303-319

Waddock, S. \& Smith, N. (2000). Relationships: the real challenge of corporate global citizenship. Business and Society Review, 105, 47-62.

WBCSD (2000). Corporate Social Responsibility: Making Good Business Sense. Geneva: WBCSD

Weber, J. \& Post, J. E. (2005). Business and Society: Stakeholders, Ethics, Public Policy. 11th Edition, McGraw-Hill

Weber, R. P. (1990). Basic Content Analysis. Beverly Hills, CA: Sage

Weiner, B. (2000). Attributional thoughts about consumer behavior. Journal of Consumer Research, Vol. 27, No. 3, pp. 382-387

Welford, R. (2004). Corporate Social Responsibility in Europe and Asia: Critical elements and best practice. Journal of Corporate Citizenship, Vol. 13, pp. 31-48

Welford, R. (2005). Corporate Social Responsibility in Europe, North America and Asia. Journal of Corporate Citizenship, Vol. 17, pp. 33-52

Weyzig, F. (2006). Local and Global Dimensions of Corporate Social Responsibility in Mexico. Journal of Corporate Citizenship, Vol. 24, pp. 69-81 
Wheeler, D. et al. (2002). Paradoxes and Dilemmas for Stakeholder Responsive Firms in the Extractive Sector: Lessons from the Case of Shell and the Ogoni. Journal of Business Ethics, Vol. 39, No. 3, pp. 297-318

Wheeler, D. et al. (2003). Focusing on value: Reconciling corporate social responsibility, sustainability and a stakeholder approach in a network world. Journal of General Management, Vol. 28, No. 3, pp. 1-28

Williams, M. A. \& Siegel, D. (2000). Corporate social responsibility and financial performance: Correlation or misspecification? Strategic Management Journal, Vol. 21, No. 5, pp. 603-609

Williams, M. A. \& Siegel, D. (2001). Corporate Social Responsibility: A theory of the firm perspective. Academy of Management Review, Vol. 26, No. 1, pp. 117-127

Williamson, D. et al. (2006). Drivers of environmental behaviour in manufacturing SMEs and the implications for CSR. Journal of Business Ethics, Vol. 67, pp. 317-330

Wood, D. (1991). Corporate Social Performance Revisited. The Academy of Management Review, Vol. 16, No. 4

Wood, D. J. \& Jones, R. E. (1995). Stakeholder mismatch: A theoretical problem in empirical research on corporate social performance. International Journal of Organizational Analysis, Vol. 3, No. 3, pp. 229-67

World Bank 2012. Inclusive Green Growth: The Pathway to Sustainable Development. Washington, D.C.

World Economic Social Survey (2013). Sustainable Development Challenges. Published by Department of Economic and Social Affairs of the United Nations, New York, pp.46-48

Yilmaz, A. K. \& Flouris, T. (2010). Managing corporate sustainability: Risk management process based perspective. African Journal of Business Management Vol 4 (2), pp. 162-171

Yin, R. K. (2003). Case Study Research: Design and Methods. Thousand Oaks, CA: Sage.

Zadek, S. (2004). The Path to Corporate Responsibility. Harvard Business Review, December, pp.125-132

Zhuang, C. \& Wheale, P. (2004). Creating Sustainable Corporate Value: A Case Study of Stakeholder Relationship Management in China. Business and Society Review, Vol. 109, No. 4, pp. 507-47

Digital Sources

ACC News (2013). ACC Sustainable Development Report, 2013[Retrieved: 07.2014]. Available at: http://www.acclimited.com/newsite/pdf/ACCSustainable DevelopmentReport2013.pdf

Accounting for Sustainability (2013). Accounting for sustainability community [Retrieved: 06.2016]. Available at:https://www.accountingforsustainability.org/community/about/

AccountAbility (2015). AccountAbility I Standards [Retrieved: 03.2016]. Available at:

http://www.accountability.org/standards/index.html

Aditya Birla Management Corporation (2014). Corporate Social Responsibility - Aditya Birla Group[Retrieved: 07.2014]. Available at: http://adityabirla.com/CSR/overview/

Amul (2015). Amul spearhead 'make in rural india' with $187 \%$ growth in six years. Gujarat Cooperative Milk Marketing Federation [Retrieved: 07.2016]. Available at:http://www.amul.com/files/pdf/GCMMF-Press-Releasefor-Annual-General-Meeting-on-17th-June-2016.pdf 
Ashok Leyland (2014). CSR Report | Ashok Leyland [Retrieved: 07.2014]. Available at:

http://www.ashokleyland.com/green-mission

Atawhai, N.R.K. (2017). Social enterprise [Retrieved: 13 October 2017] Available at:

https://www.charities.gov.nz/apply-for-registration/charitable-purpose/social-enterprise/

Baker, M. 2004. Corporate social responsibility: What does it mean? Corporate Social Responsibility News and

Resources [Retrieved: 26.08.2010]. Available at: http://www.mallenbaker.net/csr/index.htm

Balmer-Lawrie (2013). Annual Report 2012-2013 [Retrieved: 07.2014]. Available at: http://www.balmerlawrie.com

Bansal, P. \& Roth, K. (2000). Why companies go green: a model of ecological responsiveness. Academy of Management Journal, Vol. 43, No. 4, 717-736. [Retrieved: 25.08.2011]. Available at:

http://dx.doi.org/10.2307/1556363

Bansal, T. \& DesJardin, M. (2015). Don't confuse sustainability with CSR [Retrieved: 20.07.2019]. Available at: https://iveybusinessjournal.com/dont-confuse-sustainability-with-csr/

Baron, D. (2001). Private politics, corporate social responsibility and integrated strategy. Journal of Economics \& Management Strategy, Vol. 10(1): 7-45. Available at: http://dx.doi.org/10.1162/105864001300122548

Ben \& Jerry's (2008). Our Values [Retrieved: 25.08.2011]. Available at: http://www.benjerry.co.uk/ourvalues/

Bharat Forge (2013). 52nd Annual report 2012-13 [Retrieved: 07.2014]. Available at:

http://bharatforge.com/investors/company-reports/annual-reports.html

Bharti Airtel Annual Report (2013). A world of Friendships [Retrieved: 07.2014]. Available at:

http://www.airtel.in/wps/wcm/connect/f5443281-e006-4f29-938d-46a4fc2ea67c/Annual-Report-of-Bharti-Airtelfor-FY-2012-2013.pdf?MOD=AJPERES

Bhat, A. (2019). Probability sampling: Definitions, methods \& examples [Retrieved: 21.07.2019]. Available at: https://www.questionpro.com/blog/probability-sampling/

Bhattacharya, S. S. et al. (2008). Development of a CSR-Strategy Framework [Retrieved: 08.2012]. Available at: http://www.readbag.com/crrconference-downloads-crrc2007bhattacharyya BHEL 2013. BHEL Sustainability Report 2012-2013 [Retrieved: 07.2014] Available at:

http://www.bhel.com/home.php

Bowd, R., Cornelissen, J., Harris, P. (2003). CSR -A Schools approach to an Inclusive Definition [25.08.2011]. Available at: www.ipr.org.uk/groups/special/csrnetwork/special16e 3

BPCL (2013). Bharat Petroleum Corporation | Sustainability Report 2013 [Retrieved: 07.2014]. Available at: http://www.bharatpetroleum.com/General/Corporatelnfo New.aspx?id=4

Brown, K. (2001). Corporate Social Responsibility: Perceptions of Indian Business [Retrieved: 22.09. 2010]. Available at: www.csmworld.org/public/pdf/

BSE (2014). Bombay Stock Exchange | PSUs [Retrieved: 11.2014]. Available at: http://www.bsepsu.com/default.asp BSR Media Center (2013). Survey of Corporate Sustainability Executives: Progress on Climate Change Requires Collaboration [Retrieved: 10.2013]. Available at: http://www.bsr.org/en/about/press-release/survey-of-corporatesustainability-executives-progress-on-climate-change-requires-collaboration.html 
Canon (2013). Corporate Philosophy and Spirit [Retrieved: 11.2013]. Available at:

http://global.canon/en/vision/philosophy.html

Census (2011). Moga District: Census 2011 data [Retrieved: 06.2014]. Available at:

http://www.census2011.co.in/census/district/595-moga.html

Chaki, D. (2013). From $\$ 1$ to $\$ 200 m$ : An Indian Success Story [Retrieved: 07.2016]. Available at:

http://www.aljazeera.com/indepth/features/2013/09/tasting-success-with-crispy-snacks-

$\underline{2013922124759906718 . h t m l}$

CNBC News (2010). Nestle: Redefining corporate social responsibility concept [Retrieved: 06:2014]. Available at: http://www.moneycontrol.com/news/business/nestle-redefining-corporate-social-responsibilityconcept $463610 . \mathrm{html}$

CNN Money (2009). Retrieved from the World Wide Web [Retrieved: 16.08.2011]. Available at:

http://money.cnn.com/magazines/fortune/global500/2008/accountability/index.html

CNN Money (2012). Global 500 [Retrieved: 12.2013]. Available at:

http://money.cnn.com/magazines/fortune/global500/2012/full list/

Coal India Report (2014). Coal India | Annual Reports \& Accounts, 2013-14 [Retrieved: 06.2014]. Available at: https://www.coalindia.in/Manage/ViewDocumentModule.aspx/

Coal India Sustainability Report (2014). Coal India | Sustainability Report, 2013-14 [Retrieved: 07.2014]. Available at:https://www.coalindia.in/Manage/ViewDocumentModule.aspx/

Commission of the European Communities (2001). Promoting a European Framework for Corporate Social Responsibility [Retrieved: 07:2011].Available at:

www.social-protection.org/gimi/gess/ShowResource.action?ressource.ressourceld=33473

Confederation of Indian Industry (2002). Corporate Social Responsibility Survey 2002 India [Retrieved: 24.09.2011]. Available at: $\underline{w w w . c i i o n l i n e . o r g}$

Cowe, Roger et al. (2002). Developing Value - The Business Case for Sustainability in Emerging Markets [Retrieved: 08.2011]. Available at: http://www.sustainability.com

CSR Europe (2008). CSR Europe. [Retrieved: 15.09.2011]. Available at:

http://www.csreurope.org/news.php?type=\&action

CSR Quest (2016). Stakeholder classification [Retrieved: 06.2016]. Available at:

http://www.csrquest.net/default.aspx?articlelD=13626\&heading=\# ftn2

CSR Wire (2008). News [Retrieved: 15.09.2011]. Available at: http://www.csrwire.com/News/13682.html

Damodar, S. K. \& Aarrevaara, Eeva (2016). Importance of sustainability and corporate social responsibility in India [Retrieved: 06.2016]. Available at:

http://www.academia.edu/22123632/Importance of Sustainability and Corporate Social Responsibility in Indi $\underline{\mathrm{a}}$

Das, B. K.\& Halder, P. K. (2011). Corporate Social Responsibility Initiatives of Oil PSUs in Assam: A Case Study of ONGC. Volume II No.2 75-83 [Retrieved: 03.2014]. Available at:

http://www.inflibnet.ac.in/ojs/index.php/MC/article/viewFile/1269/1147 
Dasgupta, S. (2011). Imperial Touch [Retrieved: 07.2016]. Available at:

http://www.businesstoday.in/magazine/cover-story/itc-among-100-year-old-companies/story/16484.html

Davis (2006). Cause Related Consumerism [Retrieved: 08.09.2011]. Available at: $\underline{w w w . b r a n d c h a n n e l . c o m}$

Dentchev, N. (2004). Corporate social performance as a business strategy. Journal of Business Ethics, Vol. 55, Issue 4, pp. 395-410 [Retrieved: 25.09.2011]. Available at: http://dx.doi.org/10.1007/s10551-004-1348-5

Dharmadhikari, C. (2014). Contemplating Gandhi. Essays on Mahatma's Life and Thought [Retrieved: 07.2016]. Available at:http://www.mkgandhi.org/ebks/contemplating-gandhi.pdf

Digparty (2016). Kizhakkambalam | Digplanet [Retrieved: 06.2016]. Available at:

www.digplenet.com/wiki/Kizhakkambalam\#Criticism of the Corporate takeover

Dr Reddy's (2012). Dr Reddy's | Sustainability Report Summary 2012 [Retrieved: 06.2014]. Available at:

http://www.drreddys.com/

Edelman (2004). Edelman Asia Pacific stakeholder study: The only way to have a friend is to be one [Retrieved: 28.09.2011]. Available at: www.edelman.com

EFY Times (2011). Motorola Mobility India employees volunteer during Global Week of Service [Retrieved: 06.2014]. Available at: http://responsibility.motorola.com/

Fair Trade Certified (2008). Transfair [Retrieved: 20.09.2011]. Available at: http://www.transfairusa.org/content/ about/pr/ 102808.php

FedEx (2003). FedEx Express introduces hybrid electric truck [Retrieved: 20.09.2011]. Available at:

http://about.van.fedex.com/newsroom/united-states-english/fedex-express-introduces-hybrid-electric-truck/

Firstpost (2014). 30\% of India is poor, says Rangarajan panel's new poverty line formula [Retrieved: 13.07.2019]. Available at: https://www.firstpost.com/india/30-of-india-is-poor-says-rangarajan-panels-new-poverty-lineformula-1606187.html

Ford India (2014). Corporate information. Ford. [Retrieved: 06.2014]. Available at:

http://www.india.ford.com/about/corporate

Friedman, M. (1970). The Social Responsibility of Business is to Increase its Profits. The New York Times Magazine, September 13, 1970 [Retrieved: 19.11.2013]. Available at:

http://www.colorado.edu/studentgroups/libertarians/issues/friedman-soc-resp-business.html

GAIL (2013). Gas Authority of India Limited | Management Discussion and Analysis 2012-13 [Retrieved: 06.2014]. Available athttp://www.gail.nic.in/final site/aboutcsr.html/

Galbreath, J. (2006). Corporate social responsibility strategy: Strategic options, global considerations. Corporate Governance, Vol. 6, No. 2, pp.175-187 [Retrieved: 25.09.2011]. Available at:

http://dx.doi.org/10.1108/14720700610655178

Gandhi Foundation (2016). Gandhiji and Sarvodaya [Retrieved: 06.2016]. Available at:

http://www.gandhifoundation.net/about\%20gandhi7.htm

Godrej Industries (2014). CSR Policy for Godrej Industries [Retrieved: 06.2014]. Available at:

http://www.godrej.com/godrej/GodrejIndustries/pdf/CSR-Policy.pdf 
Government of Canada (2012). Corporate Social Responsibility [Retrieved: 06.2014]. Available at:

http://www.ic.gc.ca/eic/site/csr-rse.nsf/eng/rs00144.html

Grace, Segran (2010). New CSR marketing trends [Retrieved: 04.09.2011]. Available at:

http://knowledge.insead.edu/CSRMarketingTrends080902.cfm

GRI (2012). Global Reporting Initiative [Retrieved: 12.2013]. Available at:

https://www.globalreporting.org/reporting/g4/Pages/default.aspx

Gupta, P. R. (2000). India Dairy [Retrieved: 06.2016]. Available at:

http://www.indiadairy.com/ind operationflood anandpattern.html

HCC (2010). Corporate Stewardship [Retrieved: 07.2014]. Available at:

http://www.hccindia.com/corporate stewardship.php?page=corporate stewardship/

Hero Motor Corp (2014). Hero [Retrieved: 07.2014]. Available at: http://www.heromotocorp.com/en-in/

Heslin, P. A.\& Ochoa, J. D. (2009). Introduction to Corporate Social Responsibility [Retrieved: 06.2011]. Available at: http://compassioninpolitics.wordpress.com/2009/03/10/introduction-to-corporate-social-responsibility-csr/

HPCL (2013). Hindustan Petroleum Corporation Limited | Annual Report 2012-13 [Retrieved: 08.2014]. Available at: http://www.hindustanpetroleum.com/

HUDCO (2013). HUDCO | Corporate Social Responsibility Initiatives [Retrieved: 07.2014]. Available at: http://www.hudco.org/Site/FormTemplete/frmTemp1PLargeTC1C P.aspx?Mnld=281\&ParentID=0

Husted, B.W. \& Allen, D.B. (2007). Strategic Corporate Social Responsibility and Value creation among large firms". [Retrieved on 25.06.2017] Available at: http://www.elsevier.com/locate//rp

Hwee, O.B. (2016). Stewardship: Fostering the long-term success of a company [Retrieved on 13 October 2017] Available at: http://www.hrdmag.com.sg/news/stewardship-fostering-the-longterm-success-of-a-company$\underline{\text { 213828.aspx }}$

IFAC (2016). Time to Act: The Accountancy Profession's Contribution to Sustainable Development Goals [Retrieved: 06.2016]. Available at: http://www.ifac.org/global-knowledge-gateway/viewpoints/time-act-accountancyprofession-s-contribution-sustainable

Intel India (2010). 2009 Corporate Responsibility Report [Retrieved: 06.2014]. Available at: http://www.intel.com/content/dam/doc/report/corporate-responsibility-2009-india-report.pdf

International Institute of Sustainable Development (2013). Nike Case Study [Retrieved: 23.11.2013]. Available at: http://www.iisd.org/business/viewcasestudy.aspx?id=81

IPMA (2016). 10 Key Principles of Stakeholder Engagement. Association for Project Management [Retrieved: 06.2016]. Available at:https://www.apm.org.uk/stakeholder-engagement/key-principles

ISO (2014). How to use the GRI G4 Guidelines and ISO 26000 in conjunction [Retrieved: 03.2016]. Available at: http://www.iso.org/iso/iso-gri-26000 2014-01-28.pdf

ITC Limited (2014). Sustainability Report [Retrieved: 07.2014]. Available at: http://www.itcportal.com/aboutitc/policies/sustainability-policy.aspx/ 
Ittyipe, M. (2015). A Corp's new clothes. Outlook [Retrieved: 06.2016]. Available at:

http://www.outlookindia.com/magazine/story/a-corps-new-clothes/295855

IUCN/UNEP/WWF (1991). Caring for the earth. A strategy for sustainable living [Retrieved: 24.11.2013]. Available at: https://portals.iucn.org/library/efiles/documents/cfe-003.pdf

Jain, A. \& Gopalan, S. (2017). In India, a legislative reform is needed to push corporate social responsibility [Retrieved: 13.08.2019]. Available at: https://theconversation.com/in-india-a-legislative-reform-is-needed-topush-corporate-social-responsibility-80169

James, Epstein-Reeves (2003). Six Reasons Companies Should Embrace CSR [Retrieved: 21.11.2013]. Available at: http://www.forbes.com/sites/csr/2012/02/21/six-reasons-companies-should-embrace-csr/

JSW (2013). JSW Foundation [Retrieved: 07.2014]. Available at:

http://www.jsw.in/Foundation/index.php\#jswFoundation/

Kaul, D. (2007). Coca-Cola India's Corporate Social Responsibility Strategy [Retrieved: 14.09.2011]. Available at: http://www.icmrindia.org/casestudies/ catalogue/BusinessEthics/Coca-Colalndia-CorporateSocialResponsibility Strategy.htm

Krish (2010). Marketing and corporate social responsibility [Retrieved: 22.09.2011]. Available at: http://ayushveda.com/blogs/business/

Kristen, C. (2013). Companies shifting from Commitment to Action in the Drive Towards a Sustainable Future, Public Affairs and Media Relations, UN Global Compact [Retrieved: 21.11.2013]. Available at:

http://www.unglobalcompact.org/news/381-09-05-2013

Kumar, S.M.K. (2015). Kitex gives T20 a new spin in Kizhakkambalam. The Times of India [Retrieved: 06.2016]. Available at: http://timesofindia.indiatimes.com/business/india-business/Kitex-gives-T20-a-new-spin-inKizhakambalam/articleshow/47621536.cms

Lawler, E.E. (2015). Corporate stewardship [Retrieved on 13 October 2017] Available at: https://forbes.com/sites/edwardlawler/2015/09/22/corporate-stewardship/\#65eaf60eb257

Lowensohn, J. (2012). Watchdog Group Once Again Blasts Foxconn, Apple Over Labor / CNET News dated September 20, 2012 [Retrieved: 23.11.2013]. Available at: http://news.cnet.com/8301-13579 3-5751694537/watchdog-group-once-again-blasts-foxconn-apple-over-labor/

McCarty, N. (2019). India lifted 271 million people out of poverty in a decade [Retrieved: 31.07.2019]. Available at: https://www.forbes.com/sites/niallmccarthy/2019/07/12/report-india-lifted-271-million-people-out-of-povertyin-a-decade-infographic/\#4ca2b4932284

McVeigh, T.\& De Leon, S. L. (2011). Philippines floods: Victims tell of panic as well of water hit cities [Retrieved: 12.2013]. Available at: http://www.theguardian.com/world/2011/dec/17/philippines-flash-floods-victims-deaths

MHI Global (2015). MHI's CSR [Retrieved: 07.2016]. Available at: https://www.mhi-global.com/company/csr/policy/index.html

MIT Sloan Management Review (2003). The Shareholders Vs Stakeholders Debate. An article by H. Jeff Smith [Retrieved: 12.2013]. Available at: http://sloanreview.mit.edu/article/the-shareholders-vs-stakeholders-debate/

Ministry of Corporate Affairs (2012). The Companies Bill 2012 [Retrieved: 11.2013]. Available at:

http://www.mca.gov.in/Ministry/pdf/The Companies Bill 2012.pdf 
Minority Affairs (2006). Social, economic and Educational Status of the Muslim Community of India [Retrieved: 13.07.2019]. Available at: http://www.minorityaffairs.gov.in/sites/default/files/sachar comm.pdf

Morphy, T. \& Stakeholder.com (2015). Stakeholder Salience [Retrieved: 06.2016]. Available at: http://www.stakeholdermap.com/stakeholder-analysis/stakeholder-salience.html

Nayak, A. (2010). Case of British American Tobacco in India, 1906-2004 [Retrieved: 06.2016]. Available at: http://www1.ximb.ac.in/users/fac/Amar/AmarNayak.nsf/dd5cab6801f1723585256474005327c8/060eac2cc3faa4 0265256c78003ff893/\$FILE/BAT.pdf

Nieto, D. V. (2006). Marketing and CSR [Retrieved: 08.08.2010]. Available at: http://www.psfk.com/2006/11/marketing and csr.html

Nohria, N.\& Ghoshal, S. (1994). Differentiated fit and shared values: Alternatives for managing headquarterssubsidiary relations. Strategic Management Journal, Vol. 15, No. 6, pp. 491-502 [Retrieved: 25.08.2011]. Available at: $\underline{\text { http://dx.doi.org/10.1002/smj.4250150606 }}$

Nokia Sustainability Report (2011). Nokia Sustainability Report 2011 Overview [Retrieved: 06.2014]. Available at: http://i.nokia.com/blob/view/-/1449732/data/2/-/nokia-sustainability-report-2011-overview-pdf

NTPC (2013). Sustainability Report 2012-2013 [Retrieved: 07.2014]. Available at:

http://www.ntpc.co.in/index.php?option=com content\&view=article\&id=512\&ltemid=252\&lang=en/

P\&G India (2014). Sustainability [Retrieved: 07.2014]. Available at:

http://www.pg.com/en IN/sustainability/overview.shtml

Parpounas, K. (2016). Why Business Ethics are a Necessary. INCYPRUS [Retrieved: 06.2016]. Available at: http://incyprus.com/why-business-ethics-are-a-necessity/

Peston, R. (2013). BP wins reprieve over Gulf of Mexico payout. BBC News dated 3rd October 2013 [Retrieved: 12.2013]. Available at: http://www.bbc.co.uk/news/business-24377548

Rao, S. (2017). Funding needs for the UN's 2030 Development Agenda [Retrieved: 14.07.2019]. Available at: https://www.globalpolicywatch.org/blog/2017/05/29/funding-needs-for-uns-2030-development-agenda/

Raynard, P. \& Forstater, M. (2002). Corporate Social Responsibility: Implications for Small and Medium Enterprises in Developing Countries. United Nations Industrial Development Organization [Retrieved: 11.09.2014]. Available at: www.unido.org/userfiles/BethkeK/csr.pdf

RBI (2013). Table 162 Number and Percentage of Population below Poverty Line. Reserve Bank of India [Retrieved:07.2019]. Available at:

https://web.archive.org/web/20150228202954/http://www.rbi.org.in/scripts/PublicationsView.aspx?id=15283

Rediff News (2014). Amazing story of a businessman who gifted cars, flats to staff [Retrieved: 11. 2014]. Available at: http://www.rediff.com/business/report/pix-special-amazing-story-of-a-businessman-who-gifted-cars-flats-tostaff/20141024.htm

Sanborn, C. (2002). Latin American Philanthropy in Changing Times, Revista: Harvard Review of Latin America, Vol. 1, No. 3, Spring [Retrieved: 11.2011]. Available at:

http://revista.drclas.harvard.edu/book/latin-american-philanthropy-changing-times 
Sathish, R. (2010). Corporate Social Responsibility in India - Putting Social-Economic Development on a Fast Track [Retrieved: 28.09.2011]. Available at: http://www.chillibreeze.com/articles various/CSR-in-India.asp

Seth, H. B. (2011). Assessing the business case for supplier diversity in the construction housing sector. [Retrieved 01. 03. 2013]. Available at: http://irep.ntu.ac.uk/id/eprint/2/1/213848 2011 DBA Boyal-Seth Harvinder.pdf

Shah, A. (2013). Poverty Facts and Stats [Retrieved: 15.10.2013] Available at: http://www.globalissues.org/article/26/poverty-facts-and-stats

Srinivasan, R. (2014). India slips in innovation ranking. The Hindu Business Line [Retrieved: 06.2016]. Available at: http://www.thehindubusinessline.com/economy/india-slips-in-innovation-ranking/article6225908.ece

Siemens India (2013). Business Responsibility Report 2013 [Retrieved: 06.2014]. Available at:

http://www.siemens.co.in/pool/investor relations/annual report/siemens-Itd--business-responsibility-reportfy2013.pdf

Sikand, Y. (2011). Caste as a social reality did not vanish [Retrieved: 07.2014]. Available at: http://www.rediff.com/news/slide-show/slide-show-1-an-interview-with-dalit-activist-anandteltumbde/20110802.htm

Simmons, R. (2010). Social Brand Capital: The Loyalty Nucleus of Corporate Social Responsibility [Retrieved: 28.09.2011]. Available at: www.brandchannel.com

SHRM (2007). Corporate Social Responsibility Pays Off [Retrieved: 10.2011]. Available at: https://www.shrm.org/hr-today/news/hr-magazine/pages/0807cover.aspx

SKF India (2014). SKF India [Retrieved: 07.2014]. Available at: http://www.skf.com/in/our-company/index.html StatSoft (2013). Electronic Statistics Textbook. Tulsa OK. StatSoft [Retrieved: 06.2014]. Available at: http://statsoft.com/textbook/

Ström, R. (2009). CSR - A Marketing Tool? - A Case Study of ICA's and Lindex's Pink Ribbon Campaign [Retrieved: 26.09.2011]. Available at: http://www.essays.se/essay/62e9d8b1be/

Suchman, M. C. (1995). Managing Legitimacy: Strategic and Institutional Approaches. Academy of Management Review, Vol. 20, No. 3, pp. 571-610

Syntao (2013). Ellen Hertz: Foxconn and China CSR. CSR News dated 14.05.2013 [Retrieved: 23.11.2013]. Available at: http://www.syntao.com/CSRNews/CSRNews Show EN.asp?ID $=16082$

Tata Services Limited (2012). A Journey Towards an Ideal- Co-creating Sustainable Value. [Retrieved: 07.2014]. Available at: http://www.tata.com/pdf/Toolkit Value Co-creation.pdf

Tata Sons Ltd (2015). Tata profile- Leadership with trust [Retrieved: 07.2014]. Available at: http://www.tata.com/aboutus/sub index/Leadership-with-trust

The Murugappa Group (2014). Coromandel International [Retrieved: 07.2014]. Available at: http://www.murugappa.com/companies/coromandel/index.htm

UNDP (2018). The Financing Tool-Box. Financing for Development- The Global Context [Retrieved: 14.07.2019]. Available at:

https://www.undp.org/content/dam/undp/library/Sustainable\%20Development/2030\%20Agenda/Financing the $\underline{2030 \text { Agenda CO Guidebook.pdf }}$ 
UNESCO (2019). Sustainable development [Retrieved: May 2020]. Available at: https://en.unesco.org/themes/education-sustainable-development/what-isesd/sd\#: :text=There\%20are\%20four\%20dimensions\%20to,an\%20improved\%20quality\%20of\%20life.

U N Global Compact (2016). The Ten Principles of the UN Global Compact [Retrieved: 07.2016]. Available at: https://www.unglobalcompact.org/what-is-gc/mission/principles

U N Global Compact Office \& BSR (2015). Supply Chain Sustainability. A practical guide for continuous improvement. Second edition [Retrieved: 06.2016]. Available at: https://www.telenor.com/wp-content/uploads/2015/09/SupplyChainRep spread.pdf

United Nations (2004). United Nations Global Compact [Retrieved: 20.11.2013]. Available at: http://www.unglobalcompact.org/AboutTheGC/index.html

United Nations (2012). List of countries by nominal GDP [Retrieved: 12.2012]. Available at: http://unstats.un.org/unsd/snaama/dnltransfer.asp?fID $=2$

United Nations (2016). Sustainable Development Goals [Retrieved: 06.2016]. Available at:http://un.org.au/

United Nations (2017). Opening of SDG Financing Lab [Retrieved: 14.07.2019]. Available at:

https://www.un.org/pga/71/2017/04/18/opening-of-sdg-financing-lab/

Varma, S. (2014). Over 20\% of young Indians are jobless. The Times of India dated July 2, 2014 [Retrieved:

07.2014]. Available at:http://timesofindia.indiatimes.com/India/Over-20-of-young-Indians-are-

jobless/articleshow/37598409.cms

Visser, W. (2008). Corporate Social Responsibility in Developing Countries. [Retrieved: 08.2012]. Available at: http://www.academia.edu/3133076/Corporate_Social_Responsibility in Developing_Countries

Vorster, G. (2007). Corporate social responsibility is more important than the salary when choosing a job' [Retrieved: 08.2011]. Available at:

http://www.personneltoday.com/hr/corporate-social-responsibility-is-more-important-than-salary-whenchoosing-a-job/

Walker, P. (2013). Aid efforts begin after typhoon Haiyan kills 10,000 people in Philippines. The Guardian dated November 10, 2013 [Retrieved: 12.2013]. Available at:

http://www.theguardian.com/world/2013/nov/10/typhoon-haiyan-kills-10000-in-philippines-live-updates

WBCSD (2002). Corporate Social Responsibility, The WBCSD's Journey' [Retrieved: 06.2013]. Available at: http://www.cecodes.org.co/descargas/publicaciones/publicaciones wbcsd/CSR-WBCSDsJourney.pdf

WBCSD (2019). Wbcsd [Retrieved: 14.07.2019]. Available at: https://www.wbcsd.org/Overview/Aboutus/Action2020

WCED (1987). Our common future. World Commission on Environment and Development. Oxford University Press, p. 43 [Retrieved: 24.11.2013]. Available at: http://www.iisd.org/sd/

Whitehead, R. J. (2014). India leapfrogs EU as world's dominant milk producer [Retrieved: 06.2016]. Available at: http://www.foodnavigator-asia.com/Markets/India-leapfrogs-EU-as-world-s-dominant-milk-producer 
Wilson, M. (2003). Corporate Sustainability: What is it and where does it come from? Ivy Business Journal [Retrieved: 05.2016]. Available at: http://iveybusinessjournal.com/publication/corporate-sustainability-what-is-itand-where-does-it-come-from/

World Bank (2013). Regional aggregation using 2005 PPP and \$1.25/ day poverty line [Retrieved: 11.2013]. Available at: http://iresearch.worldbank.org/PovcalNet/index.htm?1

World Bank (2016). Principles and Practice in Measuring Global Poverty[Retrieved on 13.07.2019]. Available at: https://www.worldbank.org/en/news/feature/2016/01/13/principles-and-practice-in-measuring-global-poverty

World Bank (2019a). Poverty [Retrieved: 07.2019]. Available at: https://www.worldbank.org/en/topic/poverty

World Bank (2019b). Data: Access to electricity (\% of population) [Retrieved: 31.07.2019]. Available at:

https://data.worldbank.org/indicator/EG.ELC.ACCS.ZS?locations=IN

World Economic Forum (2012). The Global Competitiveness Report 2012-2013 [Retrieved: 12.2013]. Available at: http://www.weforum.org/gcr/

World Investment Report (2009). Number of MNCs in India [Retrieved: 06.2014]. Available at: http://www.numberof.net/number\%C2\%A0of\%C2\%A0mncs\%C2\%A0in\%C2\%A0india/

World Population Prospects (2017). United Nations DESA/Population Division [Retrieved: 11.2018]. Available at: https://population.un.org/wpp/

World Population Review (2019). India Population 2019 [Retrieved: 13.07.2019]. Available at:

http://worldpopulationreview.com/countries/india-population/ 


\section{LIST OF ANNEXURES}

I. Questionnaires 1, 2 and 3 for MNCs, Indian private \& public sector enterprises (Qualitative and quantitative studies)

II. Sector-wise list of MNCs, Indian private companies \& public sector enterprises operating in India sampled in the qualitative and quantitative studies

III. List of companies sampled in the qualitative and quantitative studies

IV. Views of respondents with regard to dimensions of strategic CSR Views of respondents on responsibilities of companies

V. Residual statistics and graphs plotted under regression 1 for all companies

VI. Residual statistics for regression 2 for all companies

VII. Cronbach Alpha -Item statistic 


\begin{abstract}
ANNEXURE I
CORPORATE SUSTAINABILITY \& CSR INITIATIVES OF COMPANIES OPERATING IN INDIA

Questionnaire 1 for MNCs, Indian Private \& Public Sector Enterprises undertaking Sustainability/CSR initiatives:
\end{abstract}

Please provide relevant information on the following. The information will be treated in strict confidence and is meant for research purpose only.

Type of organization (please tick) $\quad:$ MNC Indian Private PSE Others

Industry category / segment

Number of employees in India

Annual turnover in India (Previous Financial year):

Annual profits (operations in India)

1. Is your organization undertaking sustainability or CSR activities in India? Yes No

2. If answer to the above is 'yes', please list down the areas in which the sustainability and CSR activities are undertaken in India

3. When did the company initiate sustainability / CSR activities in India?

4. How often are sustainability and CSR activities undertaken in your organization
a. Daily
b.Weekly
c. Fortnighly
d. Monthly
e. Quarterly
f. Half-yearly
g. Annually
h. As per need

5. What amount of money is invested in the sustainability/CSR initiatives?

6. Do you have a budget for planning and implementing sustainability \& CSR activities
a. Yes
b. No
c. Do not know/ Can't say

7. If answer to the above is 'yes', please specify the budget

8. What are the reasons that have led to undertaking sustainability/ CSR initiatives in India? 
9. Please elaborate in detail on the sustainability and CSR initiatives undertaken in India

10. Please elaborate on the process of implementing CSR activities in your organization?

11. Who is responsible for planning and implementing the CSR activities in your organization?

12. What do you think are the advantages to your organization in implementing sustainability / CSR initiatives

13. Please elaborate on the location/area where sustainability / CSR activities are undertaken

14. Suggestions /recommendations:

Thank you 


\section{STRATEGIC CORPORATE SOCIAL RESPONSIBILITY \& VALUE CREATION}

Questionnaire 2 for MNCs, Indian Private \& Public Sector Enterprises undertaking Sustainability/CSR initiatives:

Please provide relevant information on the following. The information will be treated in strict confidence and is meant for research purpose only.

Type of organization (please tick): MNC Indian Private PSE Others

Industry category / segment

Number of employees in India

Annual Turnover in India (Previous Financial year) :

Annual profits (operations in India)

\section{A. Centrality:}

To what extent do the following objectives of social programs coincide with your firm's mission?

1.* Collaborate with community projects

$\begin{array}{cllll}\begin{array}{c}\text { O Does not } \\ \text { coincide (0\%) with }\end{array} & \begin{array}{l}\text { O Coincide to } \\ \text { some extent(25\%) }\end{array} & \begin{array}{l}\text { ○ Coincide to a } \\ \text { certain extent(50\%) }\end{array} & \begin{array}{c}\text { o Coincide to a } \\ \text { great extent(75\%) }\end{array} & \text { ○ Coincide } \\ \text { fully(100\%) } \\ \text { firm's mission } & \text { with firm's mission } & \text { with firm's mission } & \text { with firm's mission } & \text { with firm's mission }\end{array}$

Please specify the reasons for the above, if any

2. * Protect the environment

o Does not coincide (0\%) with

firm's mission o Coincide to some extent(25\%) with firm's mission o Coincide to a certain extent(50\%) with firm's mission

o Coincide to a
great extent( $75 \%)$
with firm's mission

o Coincide fully $(100 \%)$ with firm's mission

Please specify the reasons for the above, if any

\section{3. * Support social causes}

o Does not

o Coincide to coincide (0\%) with

firm's mission some extent $(25 \%)$

with firm's mission o Coincide to a certain extent (50\%) with firm's mission o Coincide to a great extent (75\%) with firm's mission o Coincide fully $(100 \%)$ with firm's mission

Please specify the reasons for the above, if any

B. Specificity:

4. Please indicate the extent to which you agree with the following statements:

* The fulfilment of the firm's social objectives is necessary to achieve its profit objectives.
o Disagree
o Agree to
○ Agree to a
$\circ$ Agree to a
o Agree
$(0 \%)$
some extent(25\%)
certain extent(50\%)
great extent(75\%)
fully(100\%) 
C. Proactivity:

5. * We scan the social environment in order to promote our firm's compliance with social expectations.
o Disagree
o Agree to
o Agree to a
o Agree to a
o Agree
(0\%) some extent(25\%)
certain extent(50\%) great extent(75\%)
fully(100\%)

6. * We are usually one of the first to adapt our corporate practices to reflect changing social expectations.
o Disagree
o Agree to
o Agree to a
o Agree to a
o Agree
some extent (25\%)
certain extent $(50 \%)$
great extent(75\%)
fully (100\%)

7. * We track the development of legislation/regulation in order to have corporate compliance mechanisms in place by the time legislation is enacted.
o Disagree
o Agree to
o Agree to a
o Agree to a
o Agree
(0\%)
some extent (25\%)
certain extent(50\%) great extent(75\%)
fully (100\%)

8. * We want to be a pioneer in adopting company policies which comply with new social expectations.
o Disagree
o Agree to
o Agree to a
o Agree to a
o Agree
$(0 \%)$
some extent(25\%)
certain extent(50\%) great extent(75\%)
fully (100\%)

D. VISIBILITY:

The purpose of participating in social action programs is to:

9. * Improve the image of the firm

$\begin{aligned} \text { o Disagree } & \text { o Agree to } \\ (0 \%) & \text { some extent }(25 \%)\end{aligned}$

o Agree to a

o Agree to a

certain extent(50\%)

great extent(75\%)

o Agree

fully (100\%)

10. * Increase the presence of the firm in the media
o Disagree
o Agree to
o Agree to a
(0\%)
some extent (25\%)
certain extent (50\%)
o Agree to a
great extent(75\%)
o Agree
fully (100\%)

E. Volunteerism:

The purpose of participating in social action programs is to:

11. * Fulfils legal obligations
o Disagree
o Agree to
o Agree to a
o Agree to a
o Agree
(0\%)
some extent(25\%)
certain extent(50\%)
great extent(75\%)
fully $(100 \%)$

12. * Follow a regular practice in the industry

o Disagree

o Agree to

o Agree to a

some extent(25\%)

certain extent(50\%)

13. * Obtains favourable tax treatment

o Disagree

(0\%) o Agree to a

certain extent(50\%) o Agree to a

great extent(75\%)

o Agree

fully (100\%)

o Agree

fully (100\%)

14. * Supports social cause

o Disagree

(0\%) o Agree to

some extent(25\%) o Agree to a

certain extent(50\%) o Agree to a

great extent(75\%)

o Agree to a

great extent(75\%) o Agree

fully (100\%) 
F. Value creation:

15. * The company influences the customer's purchase decisions
o Disagree
o Agree to
o Agree to a
o Agree to a
○ Agree
$(0 \%)$
some extent(25\%)
certain extent(50\%) great extent(75\%)
fully $(100 \%)$

16. * The company obtains / creates new customers
o Disagree
o Agree to
o Agree to a
o Agree to a
o Agree
(0\%) some extent(25\%) certain extent(50\%)
great extent $(75 \%)$
fully $(100 \%)$

17. * The company develops new products and services
o Disagree
○ Agree to
o Agree to a
o Agree to a
some extent(25\%)
certain extent $(50 \%)$
great extent (75\%)
○ Agree
fully (100\%)
18. * The company opens / enters into new markets
o Disagree
o Agree to
o Agree to a
some extent(25\%)
certain extent $(50 \%)$
o Agree to a
great extent $(75 \%)$
o Agree
fully (100\%)

Thank you for the kind attention. 


\section{STRATEGIC CORPORATE SOCIAL RESPONSIBILITY \& VALUE CREATION}

Questionnaire 3 for MNCs, Indian Private \& Public Sector Enterprises undertaking Sustainability/CSR initiatives (5-point Agreement scale)

A. Economic Responsibility

1.The primary goal of companies is to make as much profit as possible.
o Disagree
o Agree to
o Agree to a
○ Agree to a
o Agree
$(0 \%)$
some extent(25\%)
certain extent(50\%)
great extent(75\%)
fully $(100 \%)$

2. Socially responsible companies strive to lower their operational costs.
o Disagree
o Agree to
o Agree to a
○ Agree to a
o Agree
(0\%)
some extent(25\%)
certain extent $(50 \%)$
great extent(75\%)
fully (100\%)

3. Companies should strive for the highest returns to their shareholders.
○ Disagree
o Agree to
some extent(25\%)
o Agree to a
certain extent(50\%)
o Agree to a
○ Agree
great extent(75\%) fully (100\%)

4. Companies should not be distracted from their economic functions by solving social problems.
○ Disagree
o Agree to
o Agree to a
o Agree to a
o Agree
(0\%)
some extent(25\%)
certain extent( $50 \%)$
great extent(75\%)
fully $(100 \%)$

B. Legal Responsibility

5. Well run companies strive to comply with all the state laws and regulations.
o Disagree
o Agree to
o Agree to a
o Agree to a
○ Agree
$(0 \%)$
some extent(25\%)
certain extent(50\%)
great extent(75\%)
fully $(100 \%)$

6. Companies must operate strictly within the legal framework of the society.
o Disagree
o Agree to
o Agree to a
○ Agree to a
○ Agree
$(0 \%)$
some extent(25\%)
certain extent(50\%)
great extent(75\%)
fully $(100 \%)$

7. It is sometime expedient for companies to violate some laws and regulations.
o Disagree
o Agree to
o Agree to a
o Agree to a
o Agree
(0\%)
some extent(25\%)
certain extent(50\%)
great extent(75\%)
fully $(100 \%)$

8. Companies have to adhere to all state rules and regulations even though it may be costly for them.
o Disagree
o Agree to
$\circ$ Agree to a
o Agree to a
o Agree
(0\%)
some extent(25\%)
certain extent(50\%)
great extent(75\%)
fully $(100 \%)$

C. Ethical Responsibility

9. Companies should not compromise ethical norms of the society in order to achieve corporate goals.
o Disagree
o Agree to
$\circ$ Agree to a
○ Agree to a
○ Agree
$(0 \%)$
some extent(25\%)
certain extent(50\%)
great extent(75\%)
fully (100\%)

10. Socially responsible companies always do what is right, fair and just.

$\begin{array}{cl}0 \text { Disagree } & \text { o Agree to } \\ (0 \%) & \text { some extent }(25 \%)\end{array}$
o Agree to a certain extent(50\%)

O Agree to a
great extent(75\%)

○ Agree fully (100\%) 
11. Companies should avoid doing harm at all cost.
o Disagree
o Agree to
o Agree to a
- Agree to a
o Agree
(0\%)
some extent(25\%)
certain extent(50\%)
great extent(75\%)
fully $(100 \%)$

12. It is sometime expedient for companies to engage in questionable practices for economic gains.

$\begin{array}{ll}\text { O Disagree } & \text { O Agree to } \\ (0 \%) & \text { some extent( } 25 \%)\end{array}$
O Agree to a
certain extent(50\%)

o Agree to a great extent(75\%) o Agree

fully $(100 \%)$

\section{Philanthropy}

13. Companies should contribute resources to the community.
o Disagree
o Agree to
o Agree to a
○ Agree to a
o Agree
(0\%)
some extent(25\%)
certain extent(50\%)
great extent(75\%)
fully $(100 \%)$

14. Socially responsible companies strive to provide for community betterment.
o Disagree
o Agree to
o Agree to a
o Agree to a
o Agree
(0\%)
some extent(25\%)
certain extent(50\%)
great extent(75\%)
fully $(100 \%)$

15. Companies should actively promote volunteerism.
o Disagree
o Agree to
○ Agree to a
o Agree to a
o Agree
(0\%)
some extent(25\%)
certain extent( $50 \%)$
great extent(75\%)
fully $(100 \%)$

16. Companies have to commit resources to support culture and arts.
o Disagree
o Agree to
$\circ$ Agree to a
o Agree to a
o Agree
$(0 \%)$
some extent(25\%)
certain extent(50\%)
great extent(75\%)
fully $(100 \%)$

E. Charity Principle

17. Business has an obligation to needy persons in the society.
o Disagree
o Agree to
$\circ$ Agree to a
certain extent(50\%)
○ Agree to a
great extent(75\%)
○ Agree
fully $(100 \%)$

18. Business should be charitable toward the less fortunate in the society.
o Disagree
o Agree to
o Agree to a
○ Agree to a
o Agree
$(0 \%)$
some extent(25\%)
certain extent(50\%)
great extent(75\%)
fully $(100 \%)$

19. Companies should take voluntary actions to promote social good.
o Disagree
o Agree to
$\circ$ Agree to a
○ Agree to a
o Agree
$(0 \%)$
some extent(25\%)
certain extent(50\%)
great extent(75\%)
fully $(100 \%)$

20. Socially responsible companies contribute to charitable organizations.
- Disagree
o Agree to
$\circ$ Agree to a
certain extent(50\%)
o Agree to a
o Agree
great extent(75\%)
fully (100\%)

\section{F. Stewardship Principle}

21. Business has an obligation to see that everyone in the society benefits from its actions.
o Disagree
o Agree to
o Agree to a
○ Agree to a
o Agree
$(0 \%)$
some extent(25\%)
certain extent(50\%)
great extent(75\%)
fully (100\%) 
22. Business should consider the interests of all who are affected by its decisions and actions.
o Disagree
o Agree to
o Agree to a
o Agree to a
o Agree
$(0 \%)$
some extent(25\%)
certain extent(50\%)
great extent(75\%)
fully (100\%)

23. Business should balance the interests and needs of different groups in the society.
o Disagree
o Agree to
o Agree to a
o Agree to a
o Agree
(0\%)
some extent(25\%)
certain extent(50\%)
great extent(75\%)
fully $(100 \%)$

24. Business and society are interdependent.

$$
\text { o Disagree }
$$

o Agree to

some extent(25\%)
O Agree to a
certain extent(50\%)

o Agree to a great extent(75\%) o Agree

fully $(100 \%)$

G. Environmental Friendliness

25. Companies should take care of the natural environment.
o Disagree
o Agree to
o Agree to a
some extent(25\%)
certain extent( $50 \%)$
○ Agree to a
great extent(75\%)
○ Agree
fully $(100 \%)$

26. Companies should avoid damaging the natural environment.

$$
\text { o Disagree }
$$

(0\%) o Agree to

some extent(25\%) o Agree to a

certain extent(50\%) o Agree to a

great extent(75\%) o Agree

fully $(100 \%)$

27. Companies should contribute to the upkeep of the natural environment.

o Disagree

$(0 \%)$ o Agree to

some extent(25\%) o Agree to a

certain extent(50\%) o Agree to a great extent(75\%) o Agree fully (100\%)

28. Companies should have waste minimization and recycling programs.

$$
\text { o Disagree }
$$

$(0 \%)$ o Agree to some extent(25\%) $\circ$ Agree to a certain extent(50\%) o Agree to a great extent(75\%) o Agree fully $(100 \%)$

Thank you for the kind attention.

For further information the Researcher could be contacted through email: satish317@gmail.com 


\section{ANNEXURE II}

Sector wise list of companies sampled in the qualitative study:

Sector-wise list of MNCs selected during the period 2012-13

\begin{tabular}{|l|l|l|l|}
\hline S. No & Industry & Sector & No. of firms \\
\hline 1 & Manufacturing & Chemicals, Industrial products, Pharmaceuticals & 3 \\
\hline 2 & Equipment manufacturing & Telecommunication & 2 \\
\hline 3 & Equipment manufacturing & Forging, Precision tools, Steel \& Metallurgy & 2 \\
\hline 4 & $\begin{array}{l}\text { Computer manufacturing \& } \\
\text { services }\end{array}$ & Hardware, Software \& IT Consulting & 4 \\
\hline 5 & Engineeringmanufacturing & Power transmission, Energy \& Infrastructure & 5 \\
\hline 6 & Services & Logistics, Banking & 1 \\
\hline 7 & Manufacturing & Automobiles, Trucks \& Heavy vehicles & 1 \\
\hline 8 & Services & Hotels, Hospitality \& Tourism & 1 \\
\hline 9 & Consumer products manufacturing & Food \& nutrition & 5 \\
\hline & & 24 \\
\hline
\end{tabular}

Sector-wise list of Indian Private Companies selected during the period 2012-13

\begin{tabular}{|l|l|l|l|}
\hline S. No & Industry & Sector & No. of firms \\
\hline 1 & Manufacturing & Chemicals, Industrial products & 3 \\
\hline 2 & Manufacturing & Pharmaceuticals & 1 \\
\hline 3 & Manufacturing & Cement, Construction, Infrastructure & 2 \\
\hline 4 & Manufacturing & Steel, Metallurgy & 1 \\
\hline 5 & Manufacturing & Automobiles, Trucks \& Heavy vehicles & 2 \\
\hline 6 & Services & Telecommunication & 1 \\
\hline 7 & Manufacturing & Consumer products & 1 \\
\hline & & 11 \\
\hline
\end{tabular}

Sector-wise list of PSEs selected during the period 2012-13

\begin{tabular}{|l|l|l|l|}
\hline S. No & Industry & Sector & No. of firms \\
\hline 2 & Manufacturing & Cement, Construction, Real estate & 1 \\
\hline 4 & Engineering manufacturing & Power transmission, Energy \& Infrastructure & 7 \\
\hline & & & 8 \\
\hline
\end{tabular}


Sector wise list of companies sampled in the quantitative study:

Sector-wise list of MNCs selected during the period 2012-13

\begin{tabular}{|l|l|l|l|}
\hline S. No & Industry & Sector & No. of firms \\
\hline 1 & Manufacturing & Chemicals, Industrial products, Pharmaceuticals & 3 \\
\hline 2 & Equipment manufacturing & Telecommunication & 2 \\
\hline 3 & Equipment manufacturing & Forging, Precision tools, Steel \& Metallurgy & 2 \\
\hline 4 & $\begin{array}{l}\text { Computer manufacturing \& } \\
\text { services }\end{array}$ & Hardware, Software \& IT Consulting & 4 \\
\hline 5 & Engineeringmanufacturing & Power transmission, Energy \& Infrastructure & 7 \\
\hline 6 & Services & Logistics, Banking & 2 \\
\hline 7 & Manufacturing & Automobiles, Trucks \& Heavy vehicles & 3 \\
\hline 8 & Services & Hotels, Hospitality \& Tourism & 1 \\
\hline 9 & Consumer products manufacturing & Food \& nutrition & 3 \\
\hline 10 & Services & Mobile, Internet \& Telecommunication & 2 \\
\hline 11 & Services & Computer software & 1 \\
\hline & & 30 \\
\hline
\end{tabular}

Sector-wise list of Indian Private Companies selected during the period 2012-13

\begin{tabular}{|l|l|l|l|}
\hline S. No & Industry & Sector & No. of firms \\
\hline 1 & Manufacturing & Chemicals, Industrial products & 3 \\
\hline 2 & Manufacturing & Pharmaceuticals & 2 \\
\hline 3 & Manufacturing & Cement & 1 \\
\hline 4 & Manufacturing & Steel, Metallurgy & 4 \\
\hline 5 & Equipment manufacturing & Forging, Precision tools & 2 \\
\hline 6 & Engineering manufacturing & Power transmission, Energy \& Infrastructure & 6 \\
\hline 7 & Services & Logistics, Finance, Insurance & 2 \\
\hline 8 & Manufacturing & Automobiles, Trucks \& Heavy vehicles & 3 \\
\hline 9 & Services & Telecommunication & 1 \\
\hline 10 & Manufacturing & Consumer products & 2 \\
\hline & & & 26 \\
\hline
\end{tabular}

Sector-wise list of PSEs selected during the period 2012-13

\begin{tabular}{|l|l|l|l|}
\hline S. No & Industry & Sector & No. of firms \\
\hline 1 & Manufacturing & Chemicals, Fertilizers & 5 \\
\hline 2 & Manufacturing & Cement, Construction, Real estate & 3 \\
\hline 3 & Manufacturing & Steel, Metallurgy, Mining & 6 \\
\hline 4 & Engineering manufacturing & Power transmission, Energy \& Infrastructure & 9 \\
\hline 5 & Manufacturing & Consumer products, Paper, Textiles & 3 \\
\hline 6 & Services & Logistics, Banking, Finance & 6 \\
\hline 7 & Services & Trade, Exhibition & 2 \\
\hline 8 & Services & Warehousing, Storage, Distribution & 3 \\
\hline & & 37 \\
\hline
\end{tabular}




\section{ANNEXURE III}

\section{LIST OF COMPANIES SAMPLED IN THE QUALITATIVE STUDY (43 companies)}

\begin{tabular}{|ll|}
\hline MULTINATIONAL CORPORATIONS (MNCS) \\
\hline 1. & Amway \\
\hline 2. & Bharat Forge \\
\hline 3. & Canon India \\
\hline 4. & IBM India Limited \\
\hline 5. & Coca-Cola India \\
\hline 6. & Crompton Greaves Limited \\
\hline 7. & DHL India Limited \\
\hline 8. & DuPont India Limited \\
\hline 9. & Ford Motor Company Limited \\
\hline 10. & General Electric India Limited \\
\hline 11. & Glaxo SmithKline Pharmaceuticals \\
\hline 12. & Hindustan Unilever Limited \\
\hline 13. & Indian Hotels Company Limited \\
\hline 14. & Intel India Limited \\
\hline 15. & Microsoft India \\
\hline 16. & Mitsubishi Heavy Industries India \\
\hline 17. & Motorola India Limited \\
\hline 18. & Nestle India Limited \\
\hline 19. & Nokia Siemens Network \\
\hline 20. & Procter \& Gamble India Limited \\
\hline 21. & SAP India \\
\hline 22. & Siemens Limited \\
\hline 23. & SKF India Limited \\
\hline 24. & Tata Group \\
\hline & \\
\hline
\end{tabular}

\begin{tabular}{|rl|}
\hline INDIAN PRIVATE SECTOR COMPANIES (Indian private) \\
\hline 1. & ACC Limited \\
\hline 2. & Aditya Birla Group \\
\hline 3. & Ashok Leyland Limited \\
\hline 4. & Bharti Airtel Limited \\
\hline 5. & Coromandel International Limited \\
\hline 6. & Dr Reddy's Laboratories \\
\hline 7. & Godrej Industries \\
\hline 8. & Hero Motor Corp Limited \\
\hline 9. & Hindustan Construction Company Limited \\
\hline 10. & ITC Limited \\
\hline 11. & JSW Steel \\
\hline
\end{tabular}

INDIAN PUBLIC SECTOR ENTERPRISES (PSES)

1. Balmer Lawrie \& Company Limited

2. Bharat Heavy Electricals Limited

3. Bharat Petroleum Corporation Limited

4. Coal India Limited

5. Gas Authority of India Limited

6. Hindustan Petroleum Corporation Limited

7. Housing and Urban Development Corporation

8. National Thermal Power Corporation 
LIST OF COMPANIES SAMPLED IN THE QUANTITATIVE STUDY (93 companies)

\begin{tabular}{|ll|}
\hline MULTINATIONAL CORPORATIONS (MNCS) \\
\hline 1. & Akzo Nobel India Limited \\
\hline 2. & Alcatel Lucent Technologies Limited \\
\hline 3. & Bharat Forge \\
\hline 4. & IBM India Limited \\
\hline 5. & Crompton Greaves Limited \\
\hline 6. & DHL India Limited \\
\hline 7. & DuPont India Limited \\
\hline 8. & Ford Motor Company Limited \\
\hline 9. & General Electric India Limited \\
\hline 10. & Hewlett-Packard Company \\
\hline 11. & Indian Hotels Company Limited \\
\hline 12. & Intel India Limited \\
\hline 13. & Mitsubishi Heavy Industries India Private Ltd. \\
\hline 14. & Motorola Lndia limited \\
\hline 15. & Nestle India Limited \\
\hline 16. & Nokia Siemens Network \\
\hline 17. & Procter \& Gamble India Limited \\
\hline 18. & Siemens Limited \\
\hline 19. SKF India Limited \\
\hline 20. Tata Chemicals Limited \\
\hline 21. & Tata Consultancy Services \\
\hline 22. & Tata Motors Limited \\
\hline 23. & Tata Global Beverages \\
\hline 24. & Tata Steel Limited \\
\hline 25. & Tata Teleservices Limited \\
\hline 26. & Thermax Limited \\
\hline 27. & Toyota Kirloskar Motors India \\
\hline 28. & Vestas Wind Technology India Private Limited \\
\hline 29. & Videocon Group \\
\hline 30. & Vodafone India Limited \\
\hline
\end{tabular}

\begin{tabular}{|ll|}
\hline INDIAN PRIVATE SECTOR COMPANIES \\
\hline 1. & ACC Limited \\
\hline 2. & Aditya Birla Group \\
\hline 3. & Ashok Leyland Limited \\
\hline 4. & Bharti Airtel Limited \\
\hline 5. & Bhushan Steel Limited \\
\hline 6. & Coromandel International Limited \\
\hline 7. & DLF Universal Limited \\
\hline 8. & Dr Reddy's Laboratories \\
\hline 9. & Forbes \& Company Limited \\
\hline 10. Godrej Industries \\
\hline 11. Hero Motor Corp Limited \\
\hline 12. Hindustan Construction Company Ltd \\
\hline 13. IFFKO TOKYO \\
\hline 14. ITC Limited \\
\hline 15. Jindal Energy \\
\hline 16. JSW Holdings \\
\hline 17. JSW Steel \\
\hline 18. Lanco Infratech Limited \\
\hline 19. Larsen \& Toubro Limited \\
\hline 20. Mahindra and Mahindra Limited \\
\hline 21. Marico Limited \\
\hline 22. Pidilite Industries Limited \\
\hline 23. Piramal Enterprises Limited \\
\hline 24. Sterlite Industries (India) Limited \\
\hline 25. Tube Investments \\
\hline 26. Voltas Limited \\
\hline \\
\hline \\
\hline
\end{tabular}

\begin{tabular}{|cl|}
\hline INDIAN PUBLIC SECTOR ENTERPRISES (PSES) \\
\hline 1. & Balmer Lawrie \& Company Limited \\
\hline 2. & Bharat Heavy Electricals Limited \\
\hline 3. & Bharat Petroleum Corporation Limited \\
\hline 4. & Central Warehouse Corporation Limited \\
\hline 5. & Coal India Limited \\
\hline 6. & Container Corporation of India \\
\hline 7. & Engineers India Limited \\
\hline 8. & Export Credit Guarantee Corporation of India \\
\hline 9. & Gas Authority of India Limited \\
\hline 10. & Hindustan Latex Limited \\
\hline 11. & Hindustan Paper Corporation Limited \\
\hline 12. & Hindustan Petroleum Corporation Limited \\
\hline 13. & Hindustan Zinc Limited \\
\hline
\end{tabular}


14. Housing and Urban Development Corporation

15. HSCC (India) Limited

16. India Infrastructure Finance Company Limited

17. Indian Farmers Fertilizer Cooperative Limited

18. Indian Trade Promotion Organization

19. Indian Oil Corporation Limited

20. Indian Rare Earths Limited

21. Life Insurance Corporation Limited

22. Minerals and Metals Trading Corporation

23. National Aluminium Company Limited

24. National Fertilizers Limited

25. National Minerals Development Corporation

26. National Textiles Corporation Limited

27. National Thermal Power Corporation Limited

28. Neyveli Lignite Corporation Limited

29. Oil and Natural Gas Corporation Limited

30. Oil India Limited

31. Power Finance Corporation Limited

32. Power Grid Corporation of India Limited

33. Rashtriya Chemicals and Fertilizers Limited

34. Shipping Corporation of India

35. State Bank of India

36. State Trading Corporation Limited

37. Steel Authority of India Limited 


\section{ANNEXURE IV}

\section{DIMENSIONS OF STRATEGIC CSR}

Views of respondents with regarding to Dimensions of strategic CSR and Responsibilities of companies operating in India

\subsection{Centrality focuses of different companies}

The aim of establishing a "centrality" feature is to understand the basic aim of the CSR-related programmes promoted by different companies. The three different functions are taken into consideration under "centrality" include:

- Collaboration with community projects

- Protection of environment

- Support of social causes

\subsubsection{Collaboration with community projects}

Views of companies towards collaborating with community projects

\begin{tabular}{|c|c|c|c|c|c|}
\hline \multirow{11}{*}{ 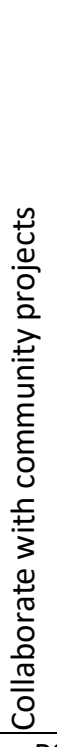 } & Suggestion & & $\begin{array}{l}\text { MNCS } \\
(n=30)\end{array}$ & $\begin{array}{l}\text { Indian private } \\
(\mathrm{n}=26)\end{array}$ & $\begin{array}{l}\text { PSES } \\
(n=37)\end{array}$ \\
\hline & \multirow{2}{*}{$\begin{array}{l}\text { Does not coincide with firm's } \\
\text { mission }\end{array}$} & Count & 0 & 0 & 0 \\
\hline & & $\%$ of total & 0 & 0 & 0 \\
\hline & \multirow{2}{*}{$\begin{array}{l}\text { Coincide to some extent with } \\
\text { firm's mission }(25 \%)\end{array}$} & Count & 0 & 2 & 2 \\
\hline & & $\%$ of total & 0 & 7.7 & 5.4 \\
\hline & \multirow{2}{*}{$\begin{array}{l}\text { Coincide to a certain extent } \\
\text { with firm's mission ( } 50 \%)\end{array}$} & Count & 4 & 3 & 2 \\
\hline & & $\%$ of total & 13.3 & 11.5 & 5.4 \\
\hline & \multirow{2}{*}{$\begin{array}{l}\text { Coincide to a great extent } \\
\text { with firm's mission (75\%) }\end{array}$} & Count & 8 & 8 & 18 \\
\hline & & $\%$ of total & 26.7 & 30.8 & 48.6 \\
\hline & \multirow{2}{*}{$\begin{array}{l}\text { Coincide fully with firm's } \\
\text { mission }(100 \%)\end{array}$} & Count & 18 & 13 & 15 \\
\hline & & $\%$ of total & 60 & 50 & 40.5 \\
\hline
\end{tabular}

The PSEs (48.6\%) believed that collaborating with community projects coincides to a great extent with their firm's mission. The majority of multinational companies (60\%) and an equal number (50\%) of Indian private sector companies indicated that the concept of collaborating with the community projects coincides fully with the firms' mission. 


\subsubsection{Promotion of environmental projects}

Views of companies towards involvement in environment protection

\begin{tabular}{|c|c|c|c|c|c|}
\hline \multirow{11}{*}{ 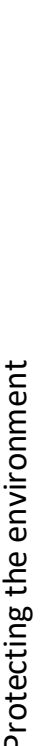 } & Suggestion & & $\begin{array}{l}\text { MNCs } \\
(n=30)\end{array}$ & $\begin{array}{l}\text { Indian private } \\
(\mathrm{n}=26)\end{array}$ & $\begin{array}{l}\text { PSEs } \\
(n=37)\end{array}$ \\
\hline & \multirow{2}{*}{$\begin{array}{l}\text { Does not coincide with } \\
\text { firm's mission }\end{array}$} & Count & 0 & 0 & 0 \\
\hline & & $\%$ of total & 0 & 0 & 0 \\
\hline & \multirow{2}{*}{$\begin{array}{l}\text { Coincide to some extent } \\
\text { with firm's mission ( } 25 \%)\end{array}$} & Count & 0 & 0 & 5 \\
\hline & & $\%$ of total & 0 & 0 & 13.5 \\
\hline & \multirow{2}{*}{$\begin{array}{l}\text { Coincide to a certain } \\
\text { extent with firm's } \\
\text { mission (50\%) }\end{array}$} & Count & 4 & 3 & 5 \\
\hline & & $\%$ of total & 13.3 & 11.5 & 13.5 \\
\hline & \multirow{2}{*}{$\begin{array}{l}\text { Coincide to a great } \\
\text { extent with firm's } \\
\text { mission (75\%) }\end{array}$} & Count & 5 & 2 & 5 \\
\hline & & $\%$ of total & 16.7 & 7.7 & 13.5 \\
\hline & \multirow{2}{*}{$\begin{array}{l}\text { Coincide fully with firm's } \\
\text { mission }(100 \%)\end{array}$} & Count & 21 & 21 & 22 \\
\hline & & $\%$ of total & 70 & 80.8 & 59.5 \\
\hline
\end{tabular}

The above table reports that majority of all companies - Indian private sector companies (80.8\%), MNCs (70\%) and public sector enterprises (59.5\%) believe that protecting the environment fully coincides with the mission of the firm.

\subsubsection{Support of social cause}

Views of companies towards involvement in supporting social cause

\begin{tabular}{|c|c|c|c|c|c|}
\hline \multirow{11}{*}{ 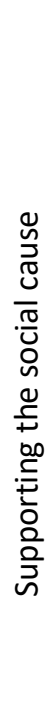 } & Suggestion & & $\begin{array}{l}\text { MNCs } \\
(n=30)\end{array}$ & $\begin{array}{l}\text { Indian private } \\
(\mathrm{n}=26)\end{array}$ & $\begin{array}{l}\text { PSEs } \\
(n=37)\end{array}$ \\
\hline & \multirow{2}{*}{ Disagree } & Count & 0 & 0 & 0 \\
\hline & & $\%$ of total & 0 & 0 & 0 \\
\hline & \multirow{2}{*}{$\begin{array}{l}\text { Agree to some } \\
\text { extent }(25 \%)\end{array}$} & Count & 0 & 0 & 0 \\
\hline & & $\%$ of total & 0 & 0 & 0 \\
\hline & \multirow{2}{*}{$\begin{array}{l}\text { Agree to a certain } \\
\text { extent }(50 \%)\end{array}$} & Count & 8 & 5 & 5 \\
\hline & & $\%$ of total & 26.7 & 19.2 & 13.5 \\
\hline & \multirow{2}{*}{$\begin{array}{l}\text { Agree to a great } \\
\text { extent }(75 \%)\end{array}$} & Count & 2 & 2 & 11 \\
\hline & & $\%$ of total & 6.7 & 7.7 & 29.7 \\
\hline & \multirow{2}{*}{$\begin{array}{l}\text { Agree fully } \\
(100 \%)\end{array}$} & Count & 20 & 19 & 21 \\
\hline & & $\%$ of total & 66.7 & 73.1 & 56.8 \\
\hline
\end{tabular}

Majority of all companies - Indian private sector companies (73.1\%), MNCs (66.7\%) and $56.8 \%$ of the public sector enterprises agree fully with firm's mission of supporting the social cause. However, it is observed that none of the companies disagree with this view. 
1.2 Specificity focus of companies

1.2.1 Involvement of companies in fulfilling social objectives

Views of companies towards involvement in the fulfilling social objectives

\begin{tabular}{|c|c|c|c|c|c|}
\hline \multirow{11}{*}{ 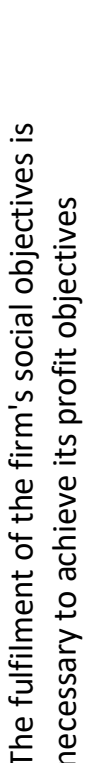 } & Suggestion & & $\begin{array}{l}\text { MNCs } \\
(n=30)\end{array}$ & $\begin{array}{l}\text { Indian private } \\
(n=26)\end{array}$ & $\begin{array}{l}\text { PSES } \\
(n=37)\end{array}$ \\
\hline & \multirow{2}{*}{ Disagree } & Count & 0 & 0 & 0 \\
\hline & & $\%$ of total & 0 & 0 & 0 \\
\hline & \multirow{2}{*}{$\begin{array}{l}\text { Agree to some } \\
\text { extent }(25 \%)\end{array}$} & Count & 0 & 0 & 3 \\
\hline & & $\%$ of total & 0 & 0 & 8.1 \\
\hline & \multirow{2}{*}{$\begin{array}{l}\text { Agree to a } \\
\text { certain extent } \\
(50 \%)\end{array}$} & Count & 0 & 7 & 4 \\
\hline & & $\%$ of total & 0 & 26.9 & 10.8 \\
\hline & \multirow{2}{*}{$\begin{array}{l}\text { Agree to a great } \\
\text { extent }(75 \%)\end{array}$} & Count & 10 & 10 & 12 \\
\hline & & $\%$ of total & 33.3 & 38.5 & 32.4 \\
\hline & \multirow{2}{*}{$\begin{array}{l}\text { Agree fully } \\
(100 \%)\end{array}$} & Count & 20 & 9 & 18 \\
\hline & & $\%$ of total & 66.7 & 34.6 & 48.6 \\
\hline
\end{tabular}

A high percent of MNCs (66.7\%), in fact, majority of the MNCs believed that fulfilment of firms' social objectives is necessary to achieve its profit objectives. Further, $48 \%$ PSEs and $34.6 \%$ of the Indian private sector companies fully agreed to this statement

\subsection{Proactivity}

1.3.1 Compliance with social expectations

Views of companies towards involvement in compliance with regard to social expectations

\begin{tabular}{|c|c|c|c|c|c|}
\hline \multirow{11}{*}{ 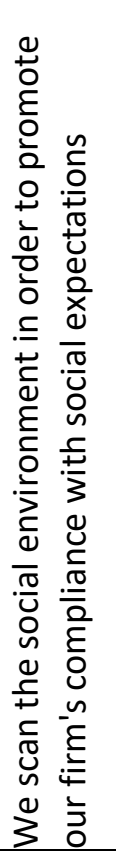 } & Suggestion & & $\begin{array}{l}\text { MNCs } \\
(n=30)\end{array}$ & $\begin{array}{l}\text { Indian private } \\
(n=26)\end{array}$ & $\begin{array}{l}\text { PSES } \\
(n=37)\end{array}$ \\
\hline & \multirow{2}{*}{ Disagree } & Count & 0 & 0 & 2 \\
\hline & & $\%$ of total & 0 & 0 & 5.4 \\
\hline & \multirow{2}{*}{$\begin{array}{l}\text { Agree to some extent } \\
(25 \%)\end{array}$} & Count & 0 & 0 & 3 \\
\hline & & $\%$ of total & 0 & 0 & 8.1 \\
\hline & \multirow{2}{*}{$\begin{array}{l}\text { Agree to a certain } \\
\text { extent }(50 \%)\end{array}$} & Count & 5 & 0 & 4 \\
\hline & & $\%$ of total & 16.7 & 0 & 10.8 \\
\hline & \multirow{2}{*}{$\begin{array}{l}\text { Agree to a great } \\
\text { extent }(75 \%)\end{array}$} & Count & 10 & 4 & 8 \\
\hline & & $\%$ of total & 33.3 & 15.4 & 21.6 \\
\hline & \multirow{2}{*}{ Agree fully (100\%) } & Count & 15 & 22 & 20 \\
\hline & & $\%$ of total & 50 & 84.6 & 54.1 \\
\hline
\end{tabular}

A large percentage of Indian private companies (84.6\%) agree fully that they scan the environment in order to promote compliance with social objectives. Further, 54.1\% PSEs agreed fully that they scan the social environment in order to promote firms' compliance with social expectations, whereas only $50 \%$ of the MNCs agreed fully with the proposed statement. 


\subsubsection{Changing social expectation}

Views of companies on adopting corporate practices to reflect changing social expectations

\begin{tabular}{|c|c|c|c|c|c|}
\hline \multirow{11}{*}{ 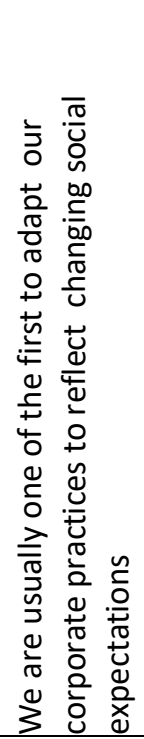 } & Suggestion & & $\begin{array}{l}\text { MNCs } \\
(n=30)\end{array}$ & $\begin{array}{l}\text { Indian private } \\
(\mathrm{n}=26)\end{array}$ & $\begin{array}{l}\text { PSEs } \\
(n=37)\end{array}$ \\
\hline & \multirow{2}{*}{ Disagree } & Count & 0 & 0 & 0 \\
\hline & & $\%$ of total & 0 & 0 & 0 \\
\hline & \multirow{2}{*}{$\begin{array}{l}\text { Agree to some extent } \\
(25 \%)\end{array}$} & Count & 0 & 2 & 0 \\
\hline & & $\%$ of total & 0 & 7.7 & 0 \\
\hline & \multirow{2}{*}{$\begin{array}{l}\text { Agree to a certain } \\
\text { extent (50\%) }\end{array}$} & Count & 4 & 0 & 5 \\
\hline & & $\%$ of total & 13.3 & 0 & 13.5 \\
\hline & \multirow{2}{*}{$\begin{array}{l}\text { Agree to a great extent } \\
(75 \%)\end{array}$} & Count & 9 & 11 & 22 \\
\hline & & $\%$ of total & 30 & 42.3 & 59.5 \\
\hline & \multirow{2}{*}{ Agree fully (100\%) } & Count & 17 & 13 & 10 \\
\hline & & $\%$ of total & 56.7 & 50 & 27 \\
\hline
\end{tabular}

The above table depicts views that majority of (56.7\%) MNCs and an equal number (50\%) of companies in the Indian private sector agree fully that they are the first to adopt corporate practices to reflect changing social expectations. It is noted that only $27 \%$ of PSEs fully agree with this statement. A majority (59.5\%) of the PSEs agree to a great extent that they are the first to adopt corporate practices to reflect changing social expectations.

\subsubsection{Track regulations and legislations}

Views of companies regarding involvement in legislation/regulation in order to have corporate compliance

\begin{tabular}{|c|c|c|c|c|c|}
\hline \multirow{11}{*}{ 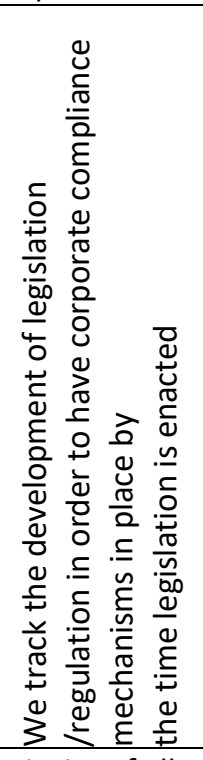 } & Suggestion & & $\begin{array}{l}\text { MNCs } \\
(n=30)\end{array}$ & $\begin{array}{l}\text { Indian private } \\
(n=26)\end{array}$ & $\begin{array}{l}\text { PSEs } \\
(n=37)\end{array}$ \\
\hline & \multirow{2}{*}{ Disagree } & Count & 0 & 0 & 5 \\
\hline & & $\%$ of total & 0 & 0 & 13.5 \\
\hline & \multirow{2}{*}{$\begin{array}{l}\text { Agree to some } \\
\text { extent }(25 \%)\end{array}$} & Count & 0 & 5 & 2 \\
\hline & & $\%$ of total & 0 & 19.2 & 5.4 \\
\hline & \multirow{2}{*}{$\begin{array}{l}\text { Agree to a } \\
\text { certain extent } \\
(50 \%)\end{array}$} & Count & 2 & 2 & 2 \\
\hline & & $\%$ of total & 6.7 & 7.7 & 5.4 \\
\hline & \multirow{2}{*}{$\begin{array}{l}\text { Agree to a great } \\
\text { extent }(75 \%)\end{array}$} & Count & 2 & 3 & 8 \\
\hline & & $\%$ of total & 6.7 & 11.5 & 21.6 \\
\hline & \multirow{2}{*}{$\begin{array}{l}\text { Agree fully } \\
(100 \%)\end{array}$} & Count & 26 & 16 & 20 \\
\hline & & $\%$ of total & 86.7 & 61.5 & 54.1 \\
\hline
\end{tabular}

Majority of all companies- a high percent of MNCs (86.7\%) and Indian private companies (61.5\%) and $54.1 \%$ of PSE's track regulations and legislations in order to have corporate compliance mechanisms in place by the time legislation is enacted 


\subsubsection{Adoption of new company policy}

Views of companies in adopting policies that comply with new social expectations

\begin{tabular}{|c|c|c|c|c|c|}
\hline \multirow{11}{*}{ 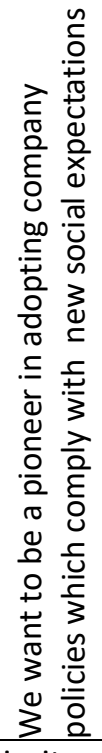 } & Suggestion & & $\begin{array}{l}\text { MNCs } \\
(n=30)\end{array}$ & $\begin{array}{l}\text { Indian private } \\
(\mathrm{n}=26)\end{array}$ & $\begin{array}{l}\text { PSEs } \\
(n=37)\end{array}$ \\
\hline & \multirow{2}{*}{ Disagree } & Count & 0 & 0 & 0 \\
\hline & & $\%$ of total & 0 & 0 & 0 \\
\hline & \multirow{2}{*}{$\begin{array}{l}\text { Agree to some extent } \\
(25 \%)\end{array}$} & Count & 0 & 2 & 0 \\
\hline & & $\%$ of total & 0 & 7.7 & 0 \\
\hline & \multirow{2}{*}{$\begin{array}{l}\text { Agree to a certain } \\
\text { extent }(50 \%)\end{array}$} & Count & 0 & 0 & 5 \\
\hline & & $\%$ of total & 0 & 0 & 13.5 \\
\hline & \multirow{2}{*}{$\begin{array}{l}\text { Agree to a great extent } \\
(75 \%)\end{array}$} & Count & 7 & 5 & 13 \\
\hline & & $\%$ of total & 23.3 & 19.2 & 35.1 \\
\hline & \multirow{2}{*}{ Agree fully (100\%) } & Count & 23 & 19 & 19 \\
\hline & & $\%$ of total & 76.7 & 73.1 & 51.4 \\
\hline
\end{tabular}

Majority of all companies - public sector enterprises (51.4\%), MNCs (76.7\%) and Indian private firms

(73.1\%) agree fully with firm's mission on adopting policies that comply with new social expectations.

\section{$1.4 \quad$ Visibility}

\subsubsection{Image of the firm}

Views of companies with regard to implementing policies in a manner that it promotes improvement of image of the firm

\begin{tabular}{|c|c|c|c|c|c|}
\hline \multirow{11}{*}{ 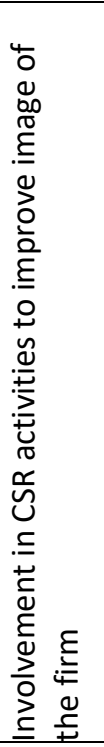 } & Suggestion & & $\begin{array}{l}\text { MNCs } \\
(n=30)\end{array}$ & $\begin{array}{l}\text { Indian private } \\
(n=26)\end{array}$ & $\begin{array}{l}\text { PSES } \\
(n=37)\end{array}$ \\
\hline & \multirow[b]{2}{*}{ Disagree } & Count & 0 & 5 & 4 \\
\hline & & $\%$ of total & 0 & 19.2 & 10.8 \\
\hline & \multirow{2}{*}{$\begin{array}{l}\text { Agree to some } \\
\text { extent }(25 \%)\end{array}$} & Count & 2 & 3 & 3 \\
\hline & & $\%$ of total & 6.7 & 11.5 & 8.1 \\
\hline & \multirow{2}{*}{$\begin{array}{l}\text { Agree to a certain } \\
\text { extent }(50 \%)\end{array}$} & Count & 10 & 12 & 9 \\
\hline & & $\%$ of total & 33.3 & 46.2 & 24.3 \\
\hline & \multirow{2}{*}{$\begin{array}{l}\text { Agree to a great } \\
\text { extent }(75 \%)\end{array}$} & Count & 9 & 3 & 9 \\
\hline & & $\%$ of total & 30 & 11.5 & 24.3 \\
\hline & \multirow{2}{*}{ Agree fully (100\%) } & Count & 9 & 3 & 12 \\
\hline & & $\%$ of total & 30 & 11.5 & 32.4 \\
\hline
\end{tabular}

A high percent of public sector enterprises (32.4\%) agree fully that firm's mission of using CSR to promote the image of the company. Both $33.3 \%$ of MNCs and $46.2 \%$ of Indian private companies neither agree nor disagree with the statement that CSR should be towards an improvement of visibility of the company. 


\subsubsection{Involvement in the media}

Views of companies regarding involvement in CSR to increase its presence in the media

\begin{tabular}{|c|c|c|c|c|c|c|}
\hline & & Suggestion & & $\begin{array}{l}\text { MNCs } \\
(n=30)\end{array}$ & $\begin{array}{l}\text { Indian private } \quad(n \\
=26)\end{array}$ & $\begin{array}{l}\text { PSES } \\
(n=37)\end{array}$ \\
\hline & & & Count & 0 & 5 & 2 \\
\hline & & Disagree & $\%$ of total & 0 & 19.2 & 5.4 \\
\hline & & Agree to some extent & Count & 13 & 10 & 16 \\
\hline$\stackrel{\sim}{\mathscr{N}}$ & $\ddot{q}$ & $(25 \%)$ & $\%$ of total & 43.3 & 38.5 & 43.2 \\
\hline$\stackrel{0}{\breve{c}}$ & $\stackrel{\Xi}{=}$ & Agree to a certain & Count & 11 & 5 & 5 \\
\hline o &.$\subseteq$ & extent (50\%) & $\%$ of total & 36.7 & 19.2 & 13.5 \\
\hline 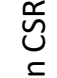 & $\underset{0}{2}$ & Agree to a great extent & Count & 4 & 6 & 14 \\
\hline$\stackrel{+}{\tilde{c}}$ & ${ }_{0}^{+}$ & $(75 \%)$ & $\%$ of total & 13.3 & 23.1 & 37.8 \\
\hline$\frac{\varepsilon}{D}$ & $\stackrel{\mathscr{U}}{\square}$ & & Count & 2 & 0 & 0 \\
\hline$\stackrel{0}{\text { I }}$ & $\stackrel{\mathscr{U}}{0}$ & AgIEe IUny $(100 \%)$ & $\%$ of total & 6.7 & 0 & 0 \\
\hline
\end{tabular}

A high percent of public sectors enterprises (43.2\%) agree to some extent that involvement in CSR increases the presence of the firm in the media. Further Indian private companies (38.5\%) and MNCs (43.3\%) also agree to some extent that involvement in CSR activities increases the presence of the firm in the media. It is also observed that none of the PSEs and Indian private companies and a small fraction (6.7\%) of MNCs fully agreed with the statement that their involvement in CSR is to increase the presence of the firm in the media.

\subsection{Voluntarism}

\subsubsection{Fulfilling legal obligations}

Views of companies with regard to promoting voluntarism by fulfilling legal obligations

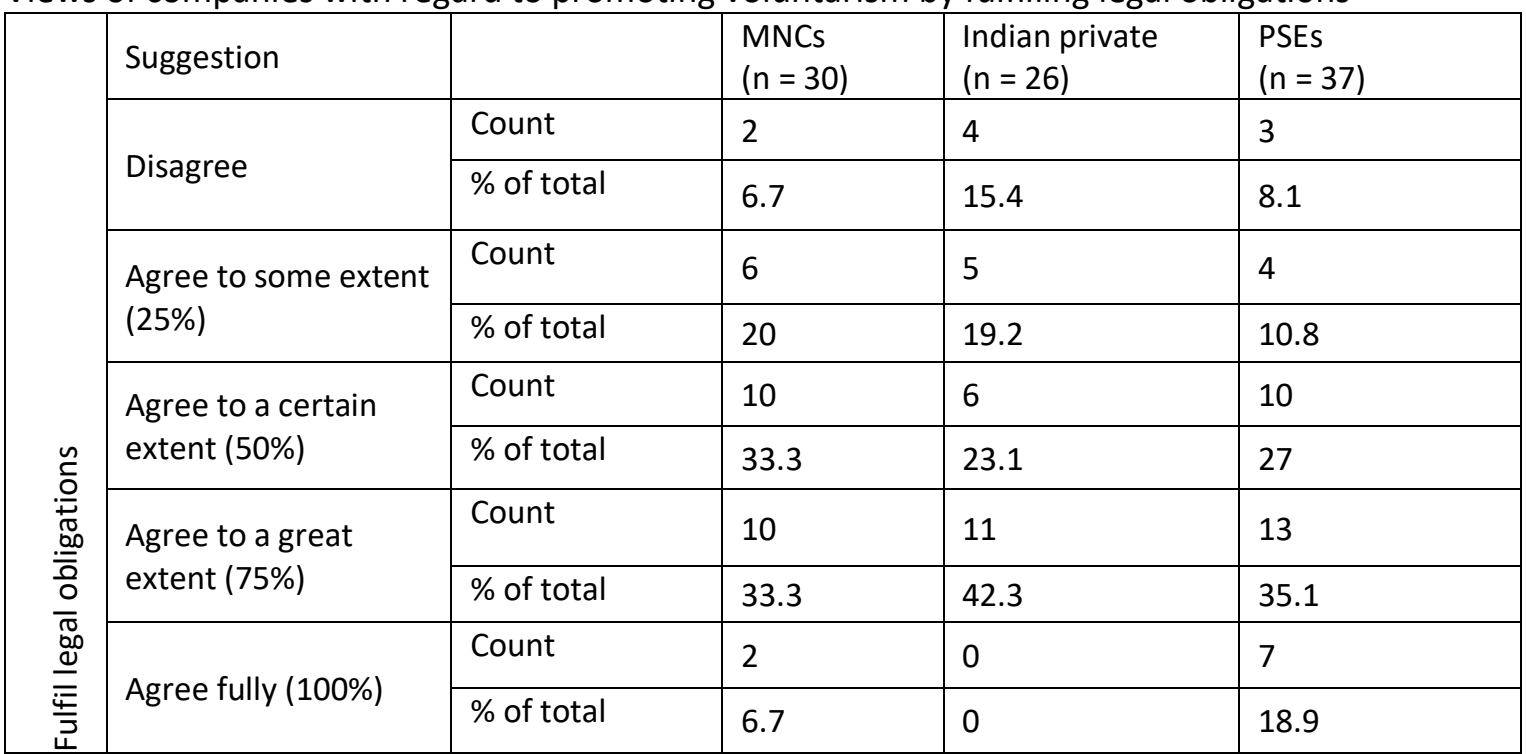

A highlights that $35.1 \%$ of PSEs (35.1\%) agree to a great extent with firm's policies on fulfilling legal obligations in terms of CSR. This could be due to the fact that CSR is one of the parameters to evaluate the performance of Managing Directors of the PSEs. Further Indian private companies (42.3\%) and MNCs (33.3\%) also agree to a great extent on the proposed statement. 
1.5.2 Regular practice in the industry

Views of companies with regard to implementing policies to promote volunteerism as a regular practice

\begin{tabular}{|c|c|c|c|c|c|}
\hline \multirow{11}{*}{ 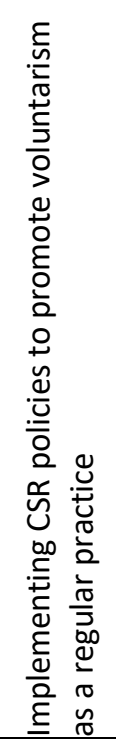 } & Suggestion & & $\begin{array}{l}\text { MNCs } \\
(n=30)\end{array}$ & $\begin{array}{l}\text { Indian private } \\
(\mathrm{n}=26)\end{array}$ & $\begin{array}{l}\text { PSES } \\
(n=37)\end{array}$ \\
\hline & \multirow{2}{*}{ Disagree } & Count & 2 & 2 & 1 \\
\hline & & $\%$ of total & 6.7 & 7.7 & 2.7 \\
\hline & \multirow{2}{*}{$\begin{array}{l}\text { Agree to some extent } \\
(25 \%)\end{array}$} & Count & 4 & 0 & 5 \\
\hline & & $\%$ of total & 13.3 & 0 & 13.5 \\
\hline & \multirow{2}{*}{$\begin{array}{l}\text { Agree to a certain } \\
\text { extent }(50 \%)\end{array}$} & Count & 7 & 8 & 6 \\
\hline & & $\%$ of total & 23.3 & 30.8 & 16.7 \\
\hline & \multirow{2}{*}{$\begin{array}{l}\text { Agree to a great } \\
\text { extent }(75 \%)\end{array}$} & Count & 15 & 10 & 21 \\
\hline & & $\%$ of total & 50 & 38.5 & 56.8 \\
\hline & \multirow{2}{*}{ Agree fully (100\%) } & Count & 2 & 6 & 4 \\
\hline & & $\%$ of total & 6.7 & 23.1 & 10.8 \\
\hline
\end{tabular}

Majority of PSEs (56.8\%) agree to a great extent that involvement in the social programme is to follow a regular practice in the industry. Rreason may be that government regulates the PSEs and made it compulsory for all profit-making PSEs undertake CSR activities. 50\% of MNCs neither agreed nor disagree.

\subsubsection{Favourable tax treatment}

Views of companies with regard to implementing CSR policies for obtaining a favourable tax treatment

\begin{tabular}{|c|c|c|c|c|c|}
\hline \multirow{11}{*}{ 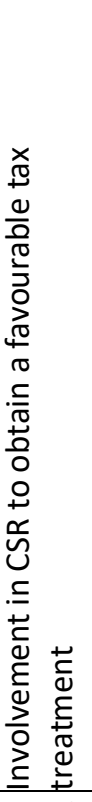 } & Suggestion & & $\begin{array}{l}\text { MNCs (n } \\
=30)\end{array}$ & $\begin{array}{l}\text { Indian private ( } \mathrm{n} \\
=26)\end{array}$ & $\begin{array}{l}\text { PSES } \\
(n=37)\end{array}$ \\
\hline & \multirow{2}{*}{ Disagree } & Count & 20 & 11 & 24 \\
\hline & & $\%$ of total & 66.7 & 42.3 & 64.9 \\
\hline & \multirow{2}{*}{$\begin{array}{l}\text { Agree to some extent } \\
(25 \%)\end{array}$} & Count & 2 & 8 & 5 \\
\hline & & $\%$ of total & 6.7 & 30.8 & 13.5 \\
\hline & \multirow{2}{*}{$\begin{array}{l}\text { Agree to a certain } \\
\text { extent (50\%) }\end{array}$} & Count & 0 & 3 & 2 \\
\hline & & $\%$ of total & 0 & 11.5 & 5.4 \\
\hline & \multirow{2}{*}{$\begin{array}{l}\text { Agree to a great } \\
\text { extent }(75 \%)\end{array}$} & Count & 3 & 4 & 3 \\
\hline & & $\%$ of total & 10 & 15.4 & 8.1 \\
\hline & \multirow{2}{*}{ Agree fully (100\%) } & Count & 5 & 0 & 3 \\
\hline & & $\%$ of total & 16.7 & 0 & 8.1 \\
\hline
\end{tabular}

Majority (66.7\%) of MNCs and majority (64.9\%) of public sector enterprises disagree with the above statement whereas $42.3 \%$ of the Indian private companies disagree with it

\subsubsection{Supporting social cause}

Views of companies with regard to implementing policies to promote volunteerism in supporting social cause 


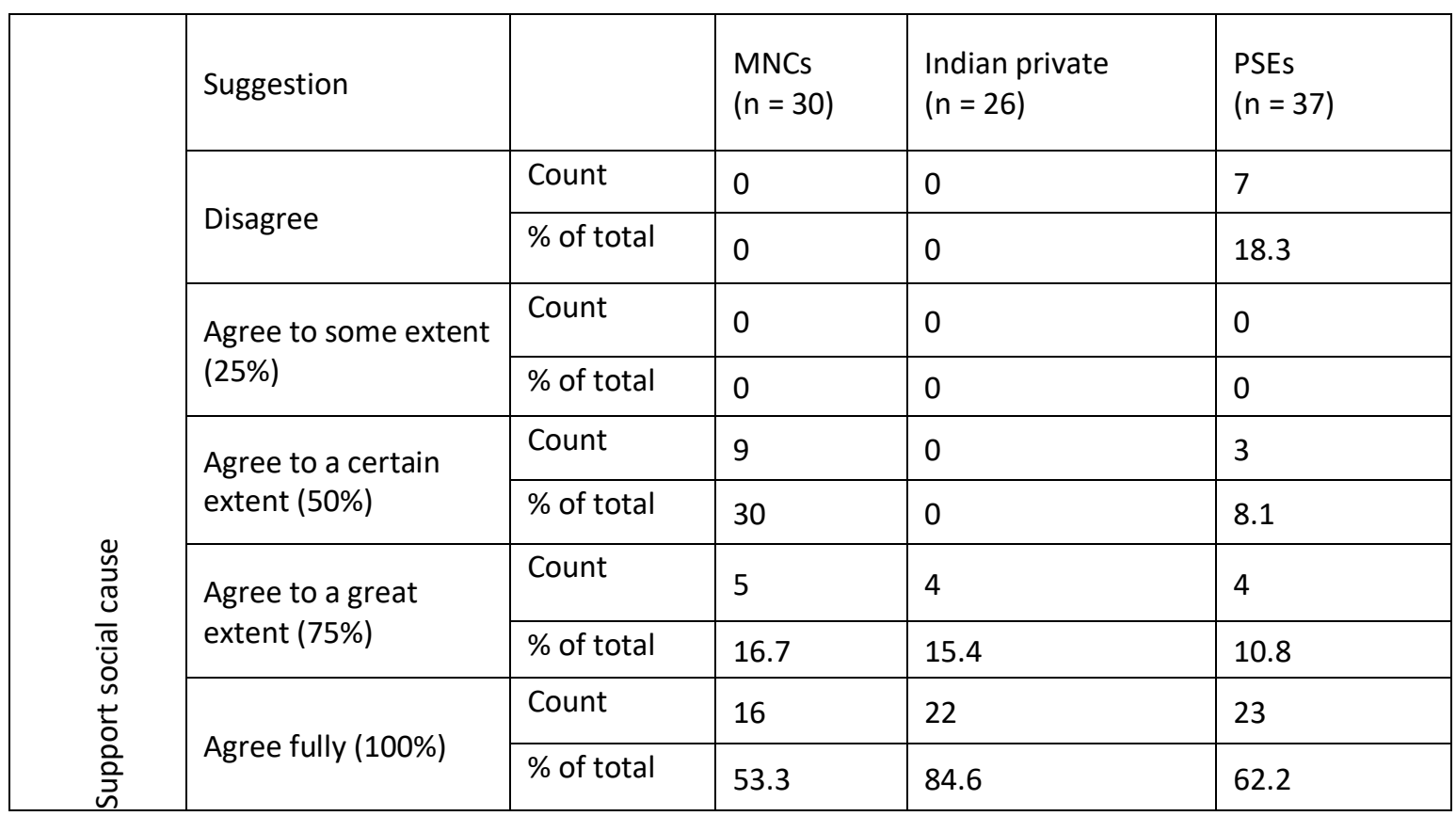

Several companies under the study- a majority of MNCs (53.3\%), Indian private companies (84.6\%) and public sector enterprises (62.2\%) agree fully in supporting the social cause.

\subsection{Value creation}

1.6.1 Influencing customers' purchase decisions Information on sectors with regard to implementation of policies in order to promote value creation by influencing purchase decisions of the customers

Views of companies with regard to implementing policies to promote value creation by influencing customers' purchase decisions

\begin{tabular}{|c|c|c|c|c|c|}
\hline \multirow{11}{*}{ 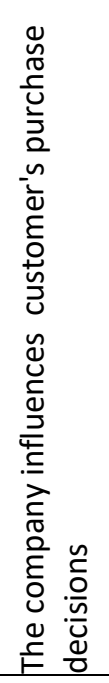 } & Suggestion & & $\begin{array}{l}\text { MNCs } \\
(n=30)\end{array}$ & $\begin{array}{l}\text { Indian private } \\
(n=26)\end{array}$ & $\begin{array}{l}\text { PSEs } \\
(n=37)\end{array}$ \\
\hline & \multirow{2}{*}{ Disagree } & Count & 2 & 3 & 9 \\
\hline & & $\%$ of total & 6.7 & 11.5 & 24.3 \\
\hline & \multirow{2}{*}{$\begin{array}{l}\text { Agree to some extent } \\
(25 \%)\end{array}$} & Count & 2 & 8 & 6 \\
\hline & & $\%$ of total & 6.7 & 30.8 & 16.5 \\
\hline & \multirow{2}{*}{$\begin{array}{l}\text { Agree to a certain } \\
\text { extent }(50 \%)\end{array}$} & Count & 10 & 7 & 11 \\
\hline & & $\%$ of total & 33.3 & 26.9 & 29.7 \\
\hline & \multirow{2}{*}{$\begin{array}{l}\text { Agree to a great } \\
\text { extent }(75 \%)\end{array}$} & Count & 9 & 7 & 7 \\
\hline & & $\%$ of total & 30 & 26.9 & 18.9 \\
\hline & \multirow{2}{*}{ Agree fully (100\%) } & Count & 7 & 1 & 4 \\
\hline & & $\%$ of total & 23.3 & 3.8 & 10.8 \\
\hline
\end{tabular}

$33 \%$ of MNCs agree to a certain extent that the company influences the customer's purchase decisions. Further Indian companies (30.8\%) agreed to some extent on the company's influence on the customer's purchase decisions. However, it was observed that about $29.7 \%$ of the public sectors enterprises neither agreed nor disagreed regarding the proposed decision. All companies were divided on the opinion regarding influencing customers' buying behaviour. 
1.6.2 Creation of new customers

Views of companies with regard to implementation of policies in obtaining/creating new customers

\begin{tabular}{|c|c|c|c|c|c|}
\hline \multirow{11}{*}{ 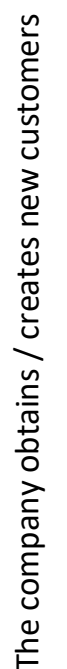 } & Suggestion & & $\begin{array}{l}\text { MNCs } \\
(n=30)\end{array}$ & $\begin{array}{l}\text { Indian private } \\
(n=26)\end{array}$ & $\begin{array}{l}\text { PSEs } \\
(n=37)\end{array}$ \\
\hline & \multirow{2}{*}{ Disagree } & Count & 3 & 3 & 5 \\
\hline & & $\%$ of total & 10 & 11.5 & 13.5 \\
\hline & \multirow{2}{*}{$\begin{array}{l}\text { Agree to some extent } \\
(25 \%)\end{array}$} & Count & 3 & 0 & 7 \\
\hline & & $\%$ of total & 10 & 0 & 18.9 \\
\hline & \multirow{2}{*}{$\begin{array}{l}\text { Agree to a certain } \\
\text { extent (50\%) }\end{array}$} & Count & 10 & 15 & 16 \\
\hline & & $\%$ of total & 33.3 & 57.7 & 43.2 \\
\hline & \multirow{2}{*}{$\begin{array}{l}\text { Agree to a great } \\
\text { extent }(75 \%)\end{array}$} & Count & 5 & 3 & 5 \\
\hline & & $\%$ of total & 16.7 & 11.5 & 13.5 \\
\hline & \multirow{2}{*}{ Agree fully (100\%) } & Count & 9 & 5 & 4 \\
\hline & & $\%$ of total & 30 & 19.2 & 5 \\
\hline
\end{tabular}

$43.2 \%$ of public sector enterprises and $33.3 \%$ of MNCs neither agrees nor disagree that the company obtains/creates new customers. The majority of the Indian private companies (57.7\%) agree to a certain extent that the company creates new customers.

\subsubsection{Development of new products}

Views of companies with regard to implementing policies to promote value creation by developing /creating new products and services

\begin{tabular}{|c|c|c|c|c|c|}
\hline \multirow{11}{*}{ 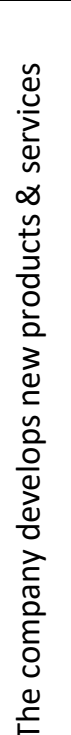 } & Suggestion & & $\begin{array}{l}\text { MNCs } \\
(n=30)\end{array}$ & $\begin{array}{l}\text { Indian private } \\
(n=26)\end{array}$ & $\begin{array}{l}\text { PSES } \\
(n=37)\end{array}$ \\
\hline & \multirow[b]{2}{*}{ Disagree } & Count & 2 & 0 & 6 \\
\hline & & $\%$ of total & 6.7 & 0 & 16.2 \\
\hline & \multirow{2}{*}{$\begin{array}{l}\text { Agree to some extent } \\
(25 \%)\end{array}$} & Count & 0 & 8 & 0 \\
\hline & & $\%$ of total & 0 & 30.8 & 0 \\
\hline & \multirow{2}{*}{$\begin{array}{l}\text { Agree to a certain } \\
\text { extent (50\%) }\end{array}$} & Count & 4 & 3 & 5 \\
\hline & & $\%$ of total & 13.3 & 11.5 & 13.5 \\
\hline & \multirow{2}{*}{$\begin{array}{l}\text { Agree to a great } \\
\text { extent }(75 \%)\end{array}$} & Count & 11 & 12 & 20 \\
\hline & & $\%$ of total & 36.7 & 46.2 & 24.1 \\
\hline & \multirow{2}{*}{ Agree fully (100\%) } & Count & 13 & 3 & 6 \\
\hline & & $\%$ of total & 43.3 & 11.5 & 16.2 \\
\hline
\end{tabular}

$43.3 \%$ of MNCs agree fully with this statement. Further Indian companies (46.2\%) and the public sector undertakings (24.1\%) agree to a great extent to the proposed statement. 
1.6.4 Entry into new markets

Views of companies with regard to implementing policies to promote value creation by opening /entering into new markets

\begin{tabular}{|c|c|c|c|c|c|}
\hline \multirow{7}{*}{ 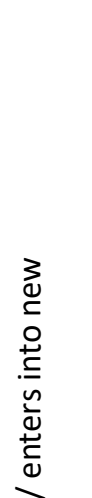 } & Suggestion & & $\begin{array}{l}\text { MNCs } \\
(n=30)\end{array}$ & $\begin{array}{l}\text { Indian private } \\
(\mathrm{n}=26)\end{array}$ & $\begin{array}{l}\text { PSEs } \\
(n=37)\end{array}$ \\
\hline & \multirow{2}{*}{ Disagree } & Count & 2 & 2 & 4 \\
\hline & & $\%$ of total & 6.7 & 7.7 & 10.8 \\
\hline & \multirow{2}{*}{$\begin{array}{l}\text { Agree to some extent } \\
(25 \%)\end{array}$} & Count & 2 & 3 & 5 \\
\hline & & $\%$ of total & 6.7 & 11.5 & 13.5 \\
\hline & \multirow{2}{*}{$\begin{array}{l}\text { Agree to a certain } \\
\text { extent (50\%) }\end{array}$} & Count & 2 & 7 & 7 \\
\hline & & $\%$ of total & 6.7 & 26.9 & 18.9 \\
\hline \multirow{4}{*}{ 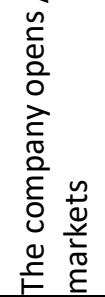 } & \multirow{2}{*}{$\begin{array}{l}\text { Agree to a great } \\
\text { extent }(75 \%)\end{array}$} & Count & 14 & 14 & 19 \\
\hline & & $\%$ of total & 46.7 & 53.8 & 51.4 \\
\hline & \multirow{2}{*}{ Agree fully (100\%) } & Count & 10 & 0 & 2 \\
\hline & & $\%$ of total & 33.3 & 0 & 5.4 \\
\hline
\end{tabular}

A majority of Indian private companies (53.8\%) and a majority of public sector enterprises (51.4\%) agree to a great extent in terms of creating value by entering new markets whereas $46.7 \%$ of MNCs identifies directly with the above statement.

\section{RESPONSIBILITIES OF COMPANIES}

\subsection{Economic responsibility}

2.1.1 Making profit

Views of companies with the primary goal of making maximum profits

\begin{tabular}{|c|c|c|c|c|c|}
\hline \multirow{11}{*}{ 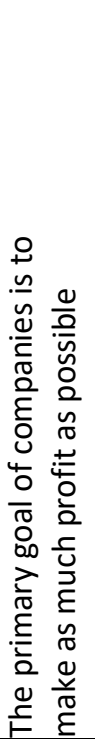 } & Suggestion & & $\begin{array}{l}\text { MNCs } \\
(n=30)\end{array}$ & $\begin{array}{l}\text { Indian private ( } n \\
=26 \text { ) }\end{array}$ & $\begin{array}{l}\text { PSEs } \\
(n=37)\end{array}$ \\
\hline & \multirow{2}{*}{ Disagree } & Count & 8 & 8 & 22 \\
\hline & & $\%$ of total & 26.7 & 30.8 & 59.45 \\
\hline & \multirow{2}{*}{$\begin{array}{l}\text { Agree to some extent } \\
(25 \%)\end{array}$} & Count & 9 & 7 & 1 \\
\hline & & $\%$ of total & 30 & 26.9 & 2.7 \\
\hline & \multirow{2}{*}{$\begin{array}{l}\text { Agree to a certain } \\
\text { extent (50\%) }\end{array}$} & Count & 3 & 5 & 3 \\
\hline & & $\%$ of total & 10 & 19.2 & 8.1 \\
\hline & \multirow{2}{*}{$\begin{array}{l}\text { Agree to a great extent } \\
(75 \%)\end{array}$} & Count & 3 & 3 & 11 \\
\hline & & $\%$ of total & 10 & 11.5 & 29.7 \\
\hline & \multirow{2}{*}{ Agree fully (100\%) } & Count & 7 & 3 & 0 \\
\hline & & $\%$ of total & 23.3 & 11.5 & 0 \\
\hline
\end{tabular}

Majority of PSEs (59.45\%) disagree with firm's mission of creating maximum profit. $30 \%$ of the participants in Indian private disagree fully that the primary goal of companies is to make as much profit as possible. However, it was to observe that about $30 \%$ of the MNCs believe to some extent that the primary goal is to make as much profit as possible. 
2.1.2 Lowering operational cost

Views of companies with regard to economic responsible by lowering operational costs

\begin{tabular}{|c|c|c|c|c|c|}
\hline \multirow{11}{*}{ 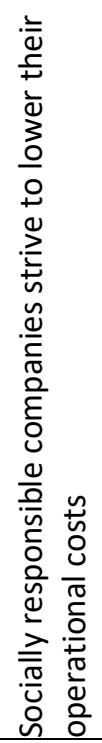 } & Suggestion & & $\begin{array}{l}\text { MNCs } \\
(n=30)\end{array}$ & $\begin{array}{l}\text { Indian private } \\
(\mathrm{n}=26)\end{array}$ & $\begin{array}{l}\text { PSEs } \\
(n=37)\end{array}$ \\
\hline & \multirow{2}{*}{ Disagree } & Count & 0 & 2 & 3 \\
\hline & & $\%$ of total & 0 & 7.7 & 8.1 \\
\hline & \multirow{2}{*}{$\begin{array}{l}\text { Agree to } \\
\text { some extent (25\%) }\end{array}$} & Count & 0 & 3 & 5 \\
\hline & & $\%$ of total & 0 & 11.5 & 13.5 \\
\hline & \multirow{2}{*}{$\begin{array}{l}\text { Agree to a certain } \\
\text { extent (50\%) }\end{array}$} & Count & 11 & 7 & 19 \\
\hline & & $\%$ of total & 36.7 & 26.9 & 51.4 \\
\hline & \multirow{2}{*}{$\begin{array}{l}\text { Agree to a great extent } \\
(75 \%)\end{array}$} & Count & 8 & 8 & 4 \\
\hline & & $\%$ of total & 26.7 & 30.8 & 10.8 \\
\hline & \multirow{2}{*}{ Agree fully (100\%) } & Count & 11 & 6 & 6 \\
\hline & & $\%$ of total & 36.7 & 23.1 & 16.2 \\
\hline
\end{tabular}

A majority of public sectors companies (51.4\%) identify to a certain being socially responsible by reducing the operational costs. However, $36.7 \%$ of the MNCs agree to a certain extent by being socially responsible in terms of lowering operational costs and an equal number (36.7\%) of MNCs agree fully that socially responsible companies strive to lower operational costs. About $30.8 \%$ of Indian private companies agree to a great extent that socially responsible companies strive to lower operational costs.

\subsubsection{Returns to shareholders}

Views of companies in promoting economic responsibility by striving for highest return to the shareholders

\begin{tabular}{|c|c|c|c|c|c|}
\hline \multirow{11}{*}{ 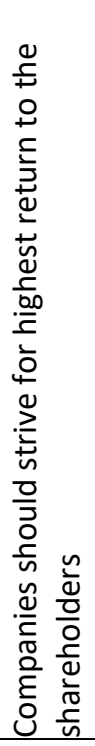 } & Suggestion & & $\begin{array}{l}\text { MNCs } \quad(n \\
=30)\end{array}$ & $\begin{array}{l}\text { Indian private } \\
(\mathrm{n}=26)\end{array}$ & $\begin{array}{l}\text { PSEs } \\
(n=37)\end{array}$ \\
\hline & \multirow[b]{2}{*}{ Disagree } & Count & 0 & 0 & 2 \\
\hline & & $\%$ of total & 0 & 0 & 5.4 \\
\hline & \multirow{2}{*}{$\begin{array}{l}\text { Agree to some extent } \\
(25 \%)\end{array}$} & Count & 4 & 0 & 2 \\
\hline & & $\%$ of total & 13.3 & 0 & 5.4 \\
\hline & \multirow{2}{*}{$\begin{array}{l}\text { Agree to a certain } \\
\text { extent }(50 \%)\end{array}$} & Count & 3 & 4 & 17 \\
\hline & & $\%$ of total & 10 & 15.4 & 45.9 \\
\hline & \multirow{2}{*}{$\begin{array}{l}\text { Agree to a great } \\
\text { extent }(75 \%)\end{array}$} & Count & 8 & 9 & 6 \\
\hline & & $\%$ of total & 26.7 & 34.6 & 16.2 \\
\hline & \multirow{2}{*}{ Agree fully (100\%) } & Count & 15 & 13 & 10 \\
\hline & & $\%$ of total & 50 & 50 & 27 \\
\hline
\end{tabular}

$50 \%$ of Indian private companies and an equal amount of MNCs agree fully with firm's policy of striving towards providing greater returns to their shareholders. However, it was to observe that about $45.9 \%$ of the public sector enterprises neither agree nor disagree with the above statement. 
2.1.4 Solving economic problems

Views of companies that they should not be distracted from their economic function by solving the social problems

\begin{tabular}{|c|c|c|c|c|c|}
\hline \multirow{11}{*}{ 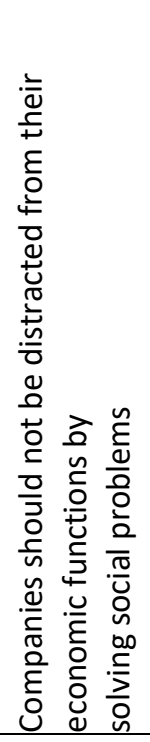 } & Suggestion & & $\begin{array}{l}\text { MNCs } \\
(n=30)\end{array}$ & $\begin{array}{l}\text { Indian private } \\
(\mathrm{n}=26)\end{array}$ & $\begin{array}{l}\text { PSES } \\
(n=37)\end{array}$ \\
\hline & \multirow{2}{*}{ Disagree } & Count & 4 & 2 & 0 \\
\hline & & $\%$ of total & 16.7 & 7.7 & 0 \\
\hline & \multirow{2}{*}{$\begin{array}{l}\text { Agree to some extent } \\
(25 \%)\end{array}$} & Count & 6 & 0 & 3 \\
\hline & & $\%$ of total & 20 & 0 & 8.1 \\
\hline & \multirow{2}{*}{$\begin{array}{l}\text { Agree to a certain } \\
\text { extent }(50 \%)\end{array}$} & Count & 6 & 18 & 25 \\
\hline & & $\%$ of total & 21 & 69.2 & 67.6 \\
\hline & \multirow{2}{*}{$\begin{array}{l}\text { Agree to a great } \\
\text { extent }(75 \%)\end{array}$} & Count & 6 & 3 & 6 \\
\hline & & $\%$ of total & 21 & 11.5 & 16.2 \\
\hline & \multirow{2}{*}{ Agree fully (100\%) } & Count & 8 & 3 & 3 \\
\hline & & $\%$ of total & 25 & 11.5 & 8.1 \\
\hline
\end{tabular}

MNCs are divided on the opinion of not being distracted from their economic functions by solving social problems. Majority of PSEs (67.6\%) \& Indian private firms (69.2\%) neither agree nor disagree

\subsection{Legal responsibility}

\subsubsection{Compliance with the law}

Views of companies in promoting legal responsibility by striving to comply with all the state laws and regulations

\begin{tabular}{|c|c|c|c|c|c|}
\hline \multirow{11}{*}{ 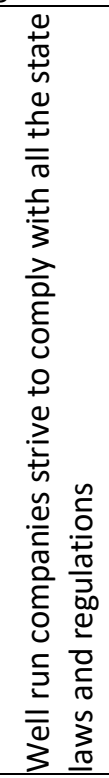 } & Suggestion & & $\begin{array}{l}\text { MNCs } \\
(n=30)\end{array}$ & $\begin{array}{l}\text { Indian private } \\
(\mathrm{n}=26)\end{array}$ & $\begin{array}{l}\text { PSEs } \\
(\mathrm{n}=37)\end{array}$ \\
\hline & \multirow{2}{*}{ Disagree } & Count & 0 & 0 & 0 \\
\hline & & $\%$ of total & 0 & 0 & 0 \\
\hline & \multirow{2}{*}{$\begin{array}{l}\text { Agree to some extent } \\
(25 \%)\end{array}$} & Count & 0 & 0 & 2 \\
\hline & & $\%$ of total & 0 & 0 & 5.4 \\
\hline & \multirow{2}{*}{$\begin{array}{l}\text { Agree to a certain } \\
\text { extent (50\%) }\end{array}$} & Count & 0 & 0 & 0 \\
\hline & & $\%$ of total & 0 & 0 & 0 \\
\hline & \multirow{2}{*}{$\begin{array}{l}\text { Agree to a great } \\
\text { extent }(75 \%)\end{array}$} & Count & 0 & 4 & 3 \\
\hline & & $\%$ of total & 0 & 15.4 & 8.1 \\
\hline & \multirow{2}{*}{ Agree fully (100\%) } & Count & 30 & 22 & 32 \\
\hline & & $\%$ of total & 100 & 84.6 & 86.5 \\
\hline
\end{tabular}

All MNCs, majority of Indian private (84.6\%) and a majority of PSEs (86.5\%) agree fully that well run companies strive to comply with all the state laws and regulations. 
2.2.2 Compliance with legal framework

Views of companies in promoting legal responsibility by complying within the legal framework of the society

\begin{tabular}{|c|c|c|c|c|c|}
\hline \multirow{11}{*}{ 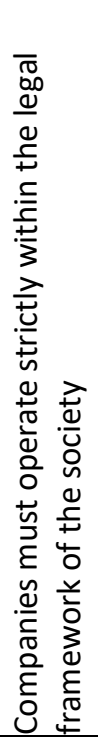 } & Suggestion & & $\begin{array}{l}\text { MNCs } \\
(n=30)\end{array}$ & $\begin{array}{l}\text { Indian private } \\
(n=26)\end{array}$ & $\begin{array}{l}\text { PSEs } \\
(n=37)\end{array}$ \\
\hline & \multirow{2}{*}{ Disagree } & Count & 0 & 0 & 8 \\
\hline & & $\%$ of total & 0 & 0 & 21.6 \\
\hline & \multirow{2}{*}{$\begin{array}{l}\text { Agree to some extent } \\
(25 \%)\end{array}$} & Count & 7 & 4 & 1 \\
\hline & & $\%$ of total & 23.3 & 15.4 & 2.7 \\
\hline & \multirow{2}{*}{$\begin{array}{l}\text { Agree to a certain } \\
\text { extent }(50 \%)\end{array}$} & Count & 3 & 5 & 4 \\
\hline & & $\%$ of total & 10 & 19.2 & 10.8 \\
\hline & \multirow{2}{*}{$\begin{array}{l}\text { Agree to a great } \\
\text { extent }(75 \%)\end{array}$} & Count & 5 & 4 & 6 \\
\hline & & $\%$ of total & 16.7 & 15.4 & 16.2 \\
\hline & \multirow{2}{*}{ Agree fully (100\%) } & Count & 15 & 13 & 18 \\
\hline & & $\%$ of total & 50 & 50 & 48.2 \\
\hline
\end{tabular}

$50 \%$ of MNCs and $50 \%$ Indian private companies agree fully with the idea that companies must operate strictly within the legal framework of the society whereas with $48.2 \%$ of PSEs fully agree with this statement.

2.2.3 Violation of some laws and regulations

Views of companies in promoting legal responsibility in terms of violating some laws and regulations

\begin{tabular}{|c|c|c|c|c|c|}
\hline \multirow{11}{*}{ 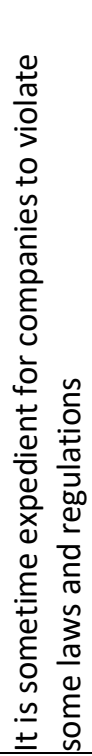 } & Suggestion & & $\begin{array}{l}\text { MNCs } \\
(n=30)\end{array}$ & $\begin{array}{l}\text { Indian private } \\
(\mathrm{n}=26)\end{array}$ & $\begin{array}{l}\text { PSEs } \\
(n=37)\end{array}$ \\
\hline & \multirow{2}{*}{ Disagree } & Count & 23 & 17 & 26 \\
\hline & & $\%$ of total & 76.7 & 65.4 & 70.3 \\
\hline & \multirow{2}{*}{$\begin{array}{l}\text { Agree to some extent } \\
(25 \%)\end{array}$} & Count & 0 & 3 & 0 \\
\hline & & $\%$ of total & 0 & 11.5 & 0 \\
\hline & \multirow{2}{*}{$\begin{array}{l}\text { Agree to a certain } \\
\text { extent (50\%) }\end{array}$} & Count & 0 & 3 & 1 \\
\hline & & $\%$ of total & 0 & 11.5 & 2.7 \\
\hline & \multirow{2}{*}{$\begin{array}{l}\text { Agree to a great } \\
\text { extent }(75 \%)\end{array}$} & Count & 0 & 0 & 4 \\
\hline & & $\%$ of total & 0 & 0 & 10.8 \\
\hline & \multirow[b]{2}{*}{ Agree fully (100\%) } & Count & 7 & 3 & 6 \\
\hline & & $\%$ of total & 23.3 & 11.5 & 16.2 \\
\hline
\end{tabular}

Majority of all companies - MNCs (76.7\%), Indian private companies (65.4\%) and public sector enterprises (70.3\%) disagree fully that it is okay to violate some laws and regulations. 


\subsubsection{Adherence to rules and regulations}

Views of companies with regard to legal responsibility in terms of adherence to all rules and regulations even though it may be costly for them

\begin{tabular}{|c|c|c|c|c|c|}
\hline \multirow{11}{*}{ 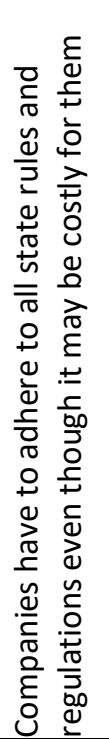 } & Suggestion & & $\begin{array}{l}\text { MNCs } \\
(n=30)\end{array}$ & $\begin{array}{l}\text { Indian private } \\
(n=26)\end{array}$ & $\begin{array}{l}\text { PSES } \\
(n=37)\end{array}$ \\
\hline & \multirow[b]{2}{*}{ Disagree } & Count & 0 & 0 & 2 \\
\hline & & $\%$ of total & 0 & 0 & 5.4 \\
\hline & \multirow{2}{*}{$\begin{array}{l}\text { Agree to some } \\
\text { extent }(25 \%)\end{array}$} & Count & 0 & 0 & 0 \\
\hline & & $\%$ of total & 0 & 0 & 0 \\
\hline & \multirow{2}{*}{$\begin{array}{l}\text { Agree to a certain } \\
\text { extent }(50 \%)\end{array}$} & Count & 0 & 0 & 2 \\
\hline & & $\%$ of total & 0 & 0 & 5.4 \\
\hline & \multirow{2}{*}{$\begin{array}{l}\text { Agree to a great } \\
\text { extent }(75 \%)\end{array}$} & Count & 0 & 2 & 0 \\
\hline & & $\%$ of total & 0 & 7.7 & 0 \\
\hline & \multirow{2}{*}{ Agree fully (100\%) } & Count & 30 & 24 & 33 \\
\hline & & $\%$ of total & 100 & 92.3 & 89.2 \\
\hline
\end{tabular}

MNCs (100\%), a majority of Indian private firms (92.3\%) and a majority of PSEs (89.2\%) agree to adhere to all rules and regulations even though it may be costly for them.

\subsection{Ethical responsibility}

\subsubsection{Importance given to ethical norms}

Views of companies in promoting ethical responsibility by non-compromise on ethical norms of the society in order to achieve its goals

\begin{tabular}{|c|c|c|c|c|c|}
\hline \multirow{11}{*}{ 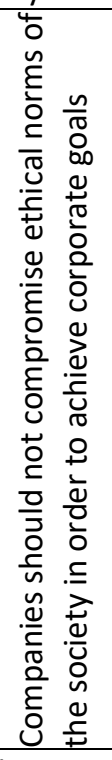 } & Suggestion & & $\begin{array}{l}\text { MNCs } \\
(n=30)\end{array}$ & $\begin{array}{l}\text { Indian private } \\
(n=26)\end{array}$ & $\begin{array}{l}\text { PSEs } \\
(n=37)\end{array}$ \\
\hline & \multirow{2}{*}{ Disagree } & Count & 0 & 0 & 2 \\
\hline & & $\%$ of total & 0 & 0 & 5.4 \\
\hline & \multirow{2}{*}{$\begin{array}{l}\text { Agree to some } \\
\text { extent }(25 \%)\end{array}$} & Count & 0 & 0 & 0 \\
\hline & & $\%$ of total & 0 & 0 & 0 \\
\hline & \multirow{2}{*}{$\begin{array}{l}\text { Agree to a certain } \\
\text { extent }(50 \%)\end{array}$} & Count & 0 & 0 & 0 \\
\hline & & $\%$ of total & 0 & 0 & 0 \\
\hline & \multirow{2}{*}{$\begin{array}{l}\text { Agree to a great } \\
\text { extent }(75 \%)\end{array}$} & Count & 0 & 7 & 2 \\
\hline & & $\%$ of total & 0 & 26.9 & 5.4 \\
\hline & \multirow{2}{*}{ Agree fully (100\%) } & Count & 30 & 19 & 33 \\
\hline & & $\%$ of total & 100 & 73.1 & 89.2 \\
\hline
\end{tabular}

All the MNCs (100\%), a majority of the Indian private firms (73.1\%) and a majority of the PSEs (89.2\%) believe fully that the company should not compromise ethical norms of the society in order to achieve corporate goals. 


\subsubsection{Functioning of the company}

Views of companies with reference to ethical responsibility in terms of doing what is right, fair and just

\begin{tabular}{|c|c|c|c|c|c|}
\hline \multirow{11}{*}{ 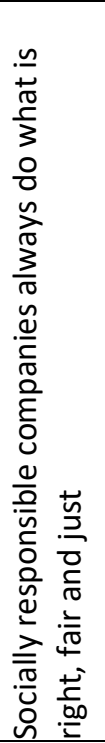 } & Suggestion & & $\begin{array}{l}\text { MNCs } \\
(n=30)\end{array}$ & $\begin{array}{l}\text { Indian private } \\
(\mathrm{n}=26)\end{array}$ & $\begin{array}{l}\text { PSEs } \\
(n=37)\end{array}$ \\
\hline & \multirow[b]{2}{*}{ Disagree } & Count & 0 & 0 & 4 \\
\hline & & $\%$ of total & 0 & 0 & 10.8 \\
\hline & \multirow{2}{*}{$\begin{array}{l}\text { Agree to some } \\
\text { extent ( } 25 \%)\end{array}$} & Count & 0 & 0 & 0 \\
\hline & & $\%$ of total & 0 & 0 & 0 \\
\hline & \multirow{2}{*}{$\begin{array}{l}\text { Agree to a certain } \\
\text { extent }(50 \%)\end{array}$} & Count & 0 & 0 & 0 \\
\hline & & $\%$ of total & 0 & 0 & 0 \\
\hline & \multirow{2}{*}{$\begin{array}{l}\text { Agree to a great } \\
\text { extent }(75 \%)\end{array}$} & Count & 0 & 2 & 3 \\
\hline & & $\%$ of total & 0 & 7.7 & 8.1 \\
\hline & \multirow{2}{*}{ Agree fully (100\%) } & Count & 30 & 24 & 30 \\
\hline & & $\%$ of total & 100 & 92.3 & 81.1 \\
\hline
\end{tabular}

All the MNCs (100\%), a majority of the Indian private firms (92.3\%) and a majority of PSEs (81.1\%) believe that a company should act socially responsible by undertaking activities that are always right, fair and just.

\subsubsection{Avoid doing harm}

Views of companies with regard to ethical responsibility in terms of avoiding harm at all cost

\begin{tabular}{|c|c|c|c|c|c|}
\hline \multirow{11}{*}{ 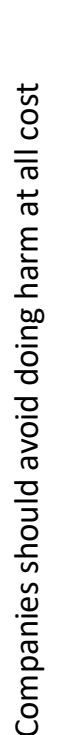 } & Suggestion & & $\begin{array}{l}\text { MNCs } \\
(n=30)\end{array}$ & $\begin{array}{l}\text { Indian private } \\
(\mathrm{n}=26)\end{array}$ & $\begin{array}{l}\text { PSEs } \\
(n=37)\end{array}$ \\
\hline & \multirow{2}{*}{ Disagree } & Count & 0 & 0 & 7 \\
\hline & & $\%$ of total & 0 & 0 & 18.9 \\
\hline & \multirow{2}{*}{$\begin{array}{l}\text { Agree to some } \\
\text { extent }(25 \%)\end{array}$} & Count & 3 & 3 & 3 \\
\hline & & $\%$ of total & 10 & 11.5 & 8.1 \\
\hline & \multirow{2}{*}{$\begin{array}{l}\text { Agree to a certain } \\
\text { extent }(50 \%)\end{array}$} & Count & 4 & 6 & 2 \\
\hline & & $\%$ of total & 13.3 & 23.1 & 5.4 \\
\hline & \multirow{2}{*}{$\begin{array}{l}\text { Agree to a great } \\
\text { extent }(75 \%)\end{array}$} & Count & 2 & 1 & 6 \\
\hline & & $\%$ of total & 6.7 & 3.8 & 16.2 \\
\hline & \multirow{2}{*}{ Agree fully (100\%) } & Count & 21 & 16 & 19 \\
\hline & & $\%$ of total & 70 & 61.5 & 51.4 \\
\hline
\end{tabular}

Majority of all companies - MNCs (70\%), Indian private firms (61.5\%) and public sector enterprises (51.4\%) agree fully that a company should act socially responsible by avoiding harm at all cost. 


\subsubsection{Engagement in questionable practice}

Views of companies with regard to ethical responsibility by engaging in questionable practices for economic gains

\begin{tabular}{|c|c|c|c|c|c|}
\hline$\frac{\frac{0}{0}}{\frac{0}{0}}$ & Suggestion & & $\begin{array}{l}\text { MNCs } \\
(n=30)\end{array}$ & $\begin{array}{l}\text { Indian private } \\
(\mathrm{n}=26)\end{array}$ & $\begin{array}{l}\text { PSEs } \\
(n=37)\end{array}$ \\
\hline$=\frac{0}{\pi}$ & Diczaroo & Count & 21 & 15 & 24 \\
\hline$\frac{0}{\partial}$ & Disagree & $\%$ of total & 70 & 57.7 & 64.9 \\
\hline & Agree to some & Count & 0 & 2 & 0 \\
\hline ष & extent (25\%) & $\%$ of total & 0 & 7.7 & 0 \\
\hline$\underset{0}{2} \underset{0}{0}$ & Agree to a certain & Count & 2 & 6 & 2 \\
\hline 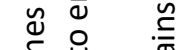 & extent $(50 \%)$ & $\%$ of total & 6.7 & 23.1 & 5.4 \\
\hline 云 & Agree to a great & Count & 5 & 0 & 0 \\
\hline 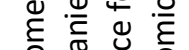 & extent (75\%) & $\%$ of total & 16.7 & 0 & 0 \\
\hline 虽 & A a o fll f1000/ & Count & 2 & 3 & 11 \\
\hline$\pm \bar{U}$ & Agree fully (100\%) & $\%$ of total & 6.7 & 11.5 & 29.7 \\
\hline
\end{tabular}

A majority of all companies - MNCs (70\%), Indian private firms (57.7\%) and public sector enterprises (64.9\%) fully disagree with indulging in questionable practices for the purpose of economic gains.

\subsection{Philanthropy}

\subsubsection{Contribution to the community}

Views of companies with regard to philanthropy by contributing resources to the community

\begin{tabular}{|c|c|c|c|c|c|}
\hline \multirow{11}{*}{ 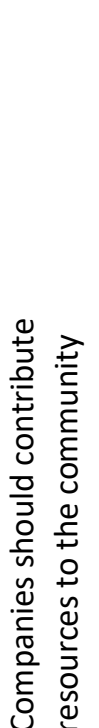 } & Suggestion & & $\begin{array}{l}\text { MNCs } \\
(n=30)\end{array}$ & $\begin{array}{l}\text { Indian private } \\
(\mathrm{n}=26)\end{array}$ & $\begin{array}{l}\text { PSEs } \\
(n=37)\end{array}$ \\
\hline & \multirow{2}{*}{ Disagree } & Count & 0 & 0 & 2 \\
\hline & & $\%$ of total & 0 & 0 & 5.4 \\
\hline & \multirow{2}{*}{$\begin{array}{l}\text { Agree to some extent } \\
(25 \%)\end{array}$} & Count & 0 & 0 & 0 \\
\hline & & $\%$ of total & 0 & 0 & 0 \\
\hline & \multirow{2}{*}{$\begin{array}{l}\text { Agree to a certain } \\
\text { extent }(50 \%)\end{array}$} & Count & 0 & 0 & 0 \\
\hline & & $\%$ of total & 0 & 0 & 0 \\
\hline & \multirow{2}{*}{$\begin{array}{l}\text { Agree to a great extent } \\
(75 \%)\end{array}$} & Count & 5 & 10 & 9 \\
\hline & & $\%$ of total & 16.7 & 38.5 & 24.3 \\
\hline & \multirow{2}{*}{ Agree fully (100\%) } & Count & 25 & 16 & 26 \\
\hline & & $\%$ of total & 83.3 & 61.5 & 70.3 \\
\hline
\end{tabular}

A majority of all companies - MNCs (83.3\%), Indian private firms (61.5\%) and PSEs (70.3\%) fully agree that a company should contribute resources to their community towards philanthropy. 


\subsubsection{Provision for community betterment}

Views of companies on philanthropic responsibility by striving to provide for community betterment

\begin{tabular}{|c|c|c|c|c|c|}
\hline \multirow{11}{*}{ 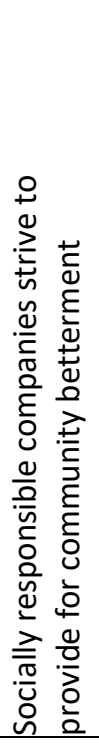 } & Suggestion & & $\begin{array}{l}\text { MNCs } \\
(n=30)\end{array}$ & $\begin{array}{l}\text { Indian private } \\
(\mathrm{n}=26)\end{array}$ & $\begin{array}{l}\text { PSES } \\
(n=37)\end{array}$ \\
\hline & \multirow{2}{*}{ Disagree } & Count & 0 & 0 & 0 \\
\hline & & $\%$ of total & 0 & 0 & 0 \\
\hline & \multirow{2}{*}{$\begin{array}{l}\text { Agree to some } \\
\text { extent }(25 \%)\end{array}$} & Count & 0 & 0 & 0 \\
\hline & & $\%$ of total & 0 & 0 & 0 \\
\hline & \multirow{2}{*}{$\begin{array}{l}\text { Agree to a certain } \\
\text { extent }(50 \%)\end{array}$} & Count & 0 & 0 & 5 \\
\hline & & $\%$ of total & 0 & 0 & 13.5 \\
\hline & \multirow{2}{*}{$\begin{array}{l}\text { Agree to a great } \\
\text { extent }(75 \%)\end{array}$} & Count & 0 & 2 & 11 \\
\hline & & $\%$ of total & 0 & 7.7 & 29.7 \\
\hline & \multirow{2}{*}{ Agree fully (100\%) } & Count & 30 & 24 & 21 \\
\hline & & $\%$ of total & 100 & 92.3 & 56.8 \\
\hline
\end{tabular}

All the MNCs (100\%); almost all the Indian private sector firms (92.3\%) and a majority of public sector enterprises (56.8\%) agree fully that a company should contribute resources to the community as a philanthropic responsibility.

\subsubsection{Promotion of volunteerism}

Views of companies on philanthropic responsibility by actively promoting volunteerism

\begin{tabular}{|c|c|c|c|c|c|}
\hline \multirow{11}{*}{ 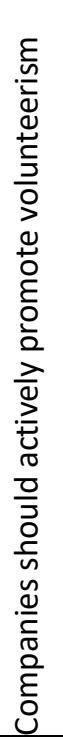 } & Suggestion & & $\begin{array}{l}\text { MNCs } \\
(n=30)\end{array}$ & $\begin{array}{l}\text { Indian private } \\
(\mathrm{n}=26)\end{array}$ & $\begin{array}{l}\text { PSES } \\
(n=37)\end{array}$ \\
\hline & \multirow{2}{*}{ Disagree } & Count & 0 & 0 & 4 \\
\hline & & $\%$ of total & 0 & 0 & 10.8 \\
\hline & \multirow{2}{*}{$\begin{array}{l}\text { Agree to some } \\
\text { extent }(25 \%)\end{array}$} & Count & 6 & 2 & 3 \\
\hline & & $\%$ of total & 2 & 7.7 & 8.1 \\
\hline & \multirow{2}{*}{$\begin{array}{l}\text { Agree to a certain } \\
\text { extent }(50 \%)\end{array}$} & Count & 2 & 0 & 4 \\
\hline & & $\%$ of total & 6.7 & 0 & 10.8 \\
\hline & \multirow{2}{*}{$\begin{array}{l}\text { Agree to a great } \\
\text { extent }(75 \%)\end{array}$} & Count & 0 & 5 & 7 \\
\hline & & $\%$ of total & 0 & 19.2 & 18.9 \\
\hline & \multirow{2}{*}{ Agree fully (100\%) } & Count & 22 & 19 & 19 \\
\hline & & $\%$ of total & 73.3 & 73.1 & 51.4 \\
\hline
\end{tabular}

A majority of all companies - MNCs (73\%), Indian private sector firms (73.1\%) and PSEs (51.4\%) fully agree that a company should promote volunteerism among their employees as a part of their philanthropic responsibility. 


\subsubsection{Support culture and arts}

Views of companies with regard to philanthropic responsibility by committing resources to support culture and arts

\begin{tabular}{|c|c|c|c|c|c|}
\hline \multirow{11}{*}{ 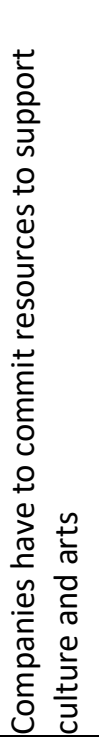 } & Suggestion & & $\begin{array}{l}\text { MNCs } \\
(n=30)\end{array}$ & $\begin{array}{l}\text { Indian private } \\
(\mathrm{n}=26)\end{array}$ & $\begin{array}{l}\text { PSEs } \\
(n=37)\end{array}$ \\
\hline & \multirow[b]{2}{*}{ Disagree } & Count & 3 & 2 & 0 \\
\hline & & $\%$ of total & 10 & 7.7 & 0 \\
\hline & \multirow{2}{*}{$\begin{array}{l}\text { Agree to some extent } \\
(25 \%)\end{array}$} & Count & 5 & 0 & 1 \\
\hline & & $\%$ of total & 16.7 & 0 & 2.7 \\
\hline & \multirow{2}{*}{$\begin{array}{l}\text { Agree to a certain } \\
\text { extent }(50 \%)\end{array}$} & Count & 5 & 4 & 3 \\
\hline & & $\%$ of total & 16.7 & 15.4 & 8.1 \\
\hline & \multirow{2}{*}{$\begin{array}{l}\text { Agree to a great extent } \\
(75 \%)\end{array}$} & Count & 2 & 3 & 7 \\
\hline & & $\%$ of total & 16.7 & 11.5 & 18.9 \\
\hline & \multirow{2}{*}{ Agree fully (100\%) } & Count & 15 & 17 & 26 \\
\hline & & $\%$ of total & 50 & 65.4 & 70.3 \\
\hline
\end{tabular}

$50 \%$ of MNCs (50\%), majority of Indian private sector firms (65.4\%) and majority of PSEs (70.3\%) agree fully that a company should support culture and arts as a part of their philanthropic responsibility.

\subsection{Charity principle}

\subsubsection{Obligation to the needy}

Views of companies with reference to charity by being obliged to the needy persons in the society

\begin{tabular}{|c|c|c|c|c|c|}
\hline \multirow{11}{*}{ 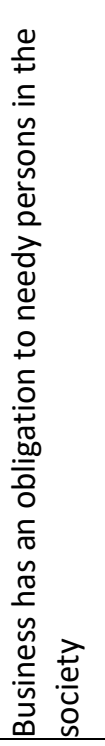 } & Suggestion & & $\begin{array}{l}\text { MNCs } \\
(n=30)\end{array}$ & $\begin{array}{l}\text { Indian private } \\
(n=26)\end{array}$ & $\begin{array}{l}\text { PSEs } \\
(n=37)\end{array}$ \\
\hline & \multirow{2}{*}{ Disagree } & Count & 0 & 3 & 0 \\
\hline & & $\%$ of total & 0 & 11.5 & 0 \\
\hline & \multirow{2}{*}{$\begin{array}{l}\text { Agree to some extent } \\
(25 \%)\end{array}$} & Count & 3 & 2 & 6 \\
\hline & & $\%$ of total & 10 & 7.7 & 16.2 \\
\hline & \multirow{2}{*}{$\begin{array}{l}\text { Agree to a certain } \\
\text { extent (50\%) }\end{array}$} & Count & 3 & 5 & 4 \\
\hline & & $\%$ of total & 10 & 19.2 & 10.8 \\
\hline & \multirow{2}{*}{$\begin{array}{l}\text { Agree to a great } \\
\text { extent }(75 \%)\end{array}$} & Count & 6 & 7 & 10 \\
\hline & & $\%$ of total & 20 & 26.9 & 27 \\
\hline & \multirow{2}{*}{ Agree fully (100\%) } & Count & 18 & 9 & 17 \\
\hline & & $\%$ of total & 60 & 34.6 & 45.9 \\
\hline
\end{tabular}

A majority of MNCs (60\%) agree fully that a company should promote charity by being obliged to the needy whereas only $34.6 \%$ of Indian private sector firms and $45.9 \%$ of the PSes fully agree that a company should promote charity by being obliged to the needy. 


\subsubsection{Charitable to the less fortunate}

Views of companies with regard to being charitable to the less fortunate

\begin{tabular}{|c|c|c|c|c|c|}
\hline \multirow{11}{*}{ 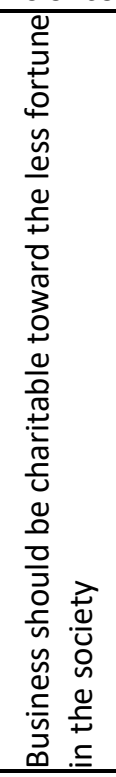 } & Suggestion & & $\begin{array}{l}\text { MNCs } \\
(n=30)\end{array}$ & $\begin{array}{l}\text { Indian private } \\
(n=26)\end{array}$ & $\begin{array}{l}\text { PSEs } \\
(n=37)\end{array}$ \\
\hline & \multirow[b]{2}{*}{ Disagree } & Count & 0 & 0 & 2 \\
\hline & & $\%$ of total & 0 & 0 & 5.4 \\
\hline & \multirow{2}{*}{$\begin{array}{l}\text { Agree to some } \\
\text { extent ( } 25 \%)\end{array}$} & Count & 3 & 2 & 5 \\
\hline & & $\%$ of total & 10 & 7.7 & 13.5 \\
\hline & \multirow{2}{*}{$\begin{array}{l}\text { Agree to a certain } \\
\text { extent }(50 \%)\end{array}$} & Count & 7 & 5 & 1 \\
\hline & & $\%$ of total & 23.3 & 19.2 & 2.7 \\
\hline & \multirow{2}{*}{$\begin{array}{l}\text { Agree to a great } \\
\text { extent }(75 \%)\end{array}$} & Count & 4 & 5 & 11 \\
\hline & & $\%$ of total & 13.3 & 19.2 & 29.7 \\
\hline & \multirow{2}{*}{ Agree fully (100\%) } & Count & 16 & 14 & 18 \\
\hline & & $\%$ of total & 53.3 & 53.8 & 48.6 \\
\hline
\end{tabular}

A majority of all companies- MNCs (53.3\%), Indian private sector firms (53.8\%) and fully agree that business should be charitable to less fortunate in the society whereas $48.6 \%$ of the public sector enterprises agree fully with this statement.

\subsubsection{Promote social good}

Views of companies with regard to charity by undertaking voluntary action in promoting social good

\begin{tabular}{|c|c|c|c|c|c|}
\hline \multirow{11}{*}{ 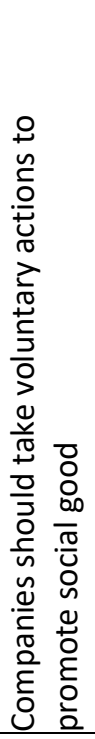 } & Suggestion & & $\begin{array}{l}\text { MNCs } \\
(n=30)\end{array}$ & $\begin{array}{l}\text { Indian private } \\
(n=26)\end{array}$ & $\begin{array}{l}\text { PSEs } \\
(n=37)\end{array}$ \\
\hline & \multirow{2}{*}{ Disagree } & Count & 0 & 0 & 0 \\
\hline & & $\%$ of total & 0 & 0 & 0 \\
\hline & \multirow{2}{*}{$\begin{array}{l}\text { Agree to some } \\
\text { extent }(25 \%)\end{array}$} & Count & 0 & 0 & 0 \\
\hline & & $\%$ of total & 0 & 0 & 0 \\
\hline & \multirow{2}{*}{$\begin{array}{l}\text { Agree to a certain } \\
\text { extent (50\%) }\end{array}$} & Count & 2 & 2 & 9 \\
\hline & & $\%$ of total & 7.7 & 7.7 & 24.3 \\
\hline & \multirow{2}{*}{$\begin{array}{l}\text { Agree to a great } \\
\text { extent }(75 \%)\end{array}$} & Count & 4 & 2 & 9 \\
\hline & & $\%$ of total & 13.3 & 7.7 & 24.3 \\
\hline & \multirow{2}{*}{ Agree fully (100\%) } & Count & 24 & 22 & 19 \\
\hline & & $\%$ of total & 80 & 84.6 & 51.4 \\
\hline
\end{tabular}

A majority of all companies - MNCs (80\%), Indian private sector firms (84.6\%) and PSEs (51.4\%) fully agree that a company should undertake charity by promoting social good. 


\subsubsection{Contribute to charitable organisations}

Views of companies with regard to promoting social responsibility by contributing to charity

\begin{tabular}{|c|c|c|c|c|c|}
\hline \multirow{11}{*}{ 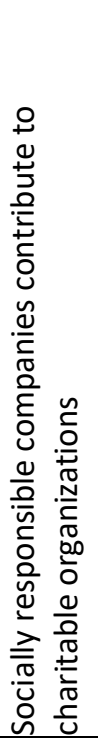 } & Suggestion & & $\begin{array}{l}\text { MNCs } \\
(n=30)\end{array}$ & $\begin{array}{l}\text { Indian private } \\
(\mathrm{n}=26)\end{array}$ & $\begin{array}{l}\text { PSEs } \\
(n=37)\end{array}$ \\
\hline & \multirow{2}{*}{ Disagree } & Count & 0 & 0 & 1 \\
\hline & & $\%$ of total & 0 & 0 & 2.7 \\
\hline & \multirow{2}{*}{$\begin{array}{l}\text { Agree to some extent } \\
(25 \%)\end{array}$} & Count & 8 & 3 & 5 \\
\hline & & $\%$ of total & 26.7 & 11.5 & 13.5 \\
\hline & \multirow{2}{*}{$\begin{array}{l}\text { Agree to a certain } \\
\text { extent }(50 \%)\end{array}$} & Count & 0 & 12 & 3 \\
\hline & & $\%$ of total & 0 & 46.2 & 8.1 \\
\hline & \multirow{2}{*}{$\begin{array}{l}\text { Agree to a great } \\
\text { extent }(75 \%)\end{array}$} & Count & 10 & 0 & 8 \\
\hline & & $\%$ of total & 33.3 & 0 & 21.6 \\
\hline & \multirow{2}{*}{ Agree fully (100\%) } & Count & 12 & 11 & 20 \\
\hline & & $\%$ of total & 40 & 42.3 & 54.1 \\
\hline
\end{tabular}

$40 \%$ of MNCs, almost equal amount of Indian private sector firms (42.3\%) and majority of public sector enterprises $(54.1 \%)$ fully agree in promoting social responsibility by contributing to charitable organisations.

\subsection{Stewardship principle}

\subsubsection{Societal benefits}

Views of companies with reference to stewardship principle such that everyone in the society is benefitted

\begin{tabular}{|c|c|c|c|c|c|}
\hline \multirow{11}{*}{ 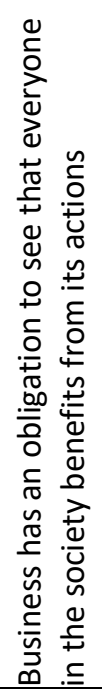 } & Suggestion & & $\begin{array}{l}\text { MNCs } \\
(n=30)\end{array}$ & $\begin{array}{l}\text { Indian private } \\
(n=26)\end{array}$ & $\begin{array}{l}\text { PSES } \\
(n=37)\end{array}$ \\
\hline & \multirow{2}{*}{ Disagree } & Count & 0 & 0 & 2 \\
\hline & & $\%$ of total & 0 & 0 & 5.4 \\
\hline & \multirow{2}{*}{$\begin{array}{l}\text { Agree to some extent } \\
(25 \%)\end{array}$} & Count & 0 & 2 & 0 \\
\hline & & $\%$ of total & 0 & 7.7 & 0 \\
\hline & \multirow{2}{*}{$\begin{array}{l}\text { Agree to a certain } \\
\text { extent (50\%) }\end{array}$} & Count & 5 & 0 & 2 \\
\hline & & $\%$ of total & 16.7 & 0 & 5.4 \\
\hline & \multirow{2}{*}{$\begin{array}{l}\text { Agree to a great } \\
\text { extent }(75 \%)\end{array}$} & Count & 7 & 6 & 11 \\
\hline & & $\%$ of total & 23.3 & 23.1 & 29.7 \\
\hline & \multirow{2}{*}{ Agree fully (100\%) } & Count & 18 & 18 & 22 \\
\hline & & $\%$ of total & 60 & 69.2 & 59.5 \\
\hline
\end{tabular}

A majority of all companies - MNCs (60\%), Indian private sector firms (69.2\%) and PSEs (59.5\%) fully agree that everyone in the society should benefit by the actions of the company. 


\subsubsection{Considering interests of all}

Views of companies with regard to stewardship principle wherein the company considers interests of those affected by its decisions and actions

\begin{tabular}{|c|c|c|c|c|c|}
\hline \multirow{11}{*}{ 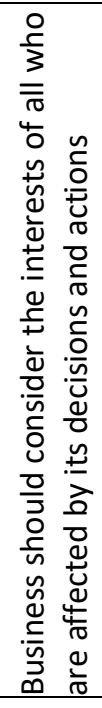 } & Suggestion & & $\begin{array}{l}\text { MNCs } \\
(\mathrm{n}=30)\end{array}$ & $\begin{array}{l}\text { Indian private } \\
(\mathrm{n}=26)\end{array}$ & $\begin{array}{l}\text { PSEs } \\
(n=37)\end{array}$ \\
\hline & \multirow{2}{*}{ Disagree } & Count & 0 & 0 & 0 \\
\hline & & $\%$ of total & 0 & 0 & 0 \\
\hline & \multirow{2}{*}{$\begin{array}{l}\text { Agree to some } \\
\text { extent }(25 \%)\end{array}$} & Count & 0 & 0 & 3 \\
\hline & & $\%$ of total & 0 & 0 & 8.1 \\
\hline & \multirow{2}{*}{$\begin{array}{l}\text { Agree to a certain } \\
\text { extent }(50 \%)\end{array}$} & Count & 0 & 0 & 2 \\
\hline & & $\%$ of total & 0 & 0 & 5.4 \\
\hline & \multirow{2}{*}{$\begin{array}{l}\text { Agree to a great } \\
\text { extent }(75 \%)\end{array}$} & Count & 7 & 2 & 10 \\
\hline & & $\%$ of total & 23.3 & 7.7 & 27 \\
\hline & \multirow{2}{*}{ Agree fully (100\%) } & Count & 23 & 24 & 22 \\
\hline & & $\%$ of total & 76.7 & 92.3 & 59.5 \\
\hline
\end{tabular}

A majority of MNCs (76.7\%), a majority of public sector enterprises (59.5\%) and most of the Indian private sector firms $(92.3 \%)$ fully agree that a company should consider the interests of all those affected by its decisions and actions.

\subsubsection{Balancing the interests of the society}

Views of companies with regard to stewardship principle where the company balancing the interests and needs of different society groups

\begin{tabular}{|c|c|c|c|c|c|}
\hline \multirow{11}{*}{ 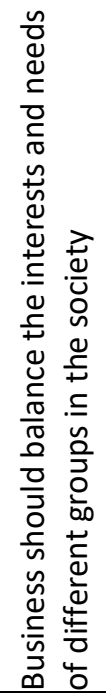 } & Suggestion & & $\begin{array}{l}\text { MNCs } \\
(n=30)\end{array}$ & $\begin{array}{l}\text { Indian private } \\
(\mathrm{n}=26)\end{array}$ & $\begin{array}{l}\text { PSEs } \\
(n=37)\end{array}$ \\
\hline & \multirow{2}{*}{ Disagree } & Count & 0 & 0 & 7 \\
\hline & & $\%$ of total & 0 & 0 & 18.9 \\
\hline & \multirow{2}{*}{$\begin{array}{l}\text { Agree to some extent } \\
(25 \%)\end{array}$} & Count & 2 & 2 & 0 \\
\hline & & $\%$ of total & 6.7 & 7.7 & 0 \\
\hline & \multirow{2}{*}{$\begin{array}{l}\text { Agree to a certain } \\
\text { extent }(50 \%)\end{array}$} & Count & 0 & 5 & 2 \\
\hline & & $\%$ of total & 0 & 19.2 & 5.4 \\
\hline & \multirow{2}{*}{$\begin{array}{l}\text { Agree to a great } \\
\text { extent }(75 \%)\end{array}$} & Count & 6 & 0 & 4 \\
\hline & & $\%$ of total & 20 & 0 & 10.8 \\
\hline & \multirow{2}{*}{ Agree fully (100\%) } & Count & 22 & 19 & 24 \\
\hline & & $\%$ of total & 73.3 & 73.1 & 64.9 \\
\hline
\end{tabular}

A majority of companies - MNCs (73.3\%), Indian private sector firms (73.1\%) and PSEs (64.9\%) fully agree that a company should balance the interests and needs of various groups in the society. 


\subsubsection{Interdependence}

Views of companies with reference to promoting stewardship by understanding the interdependence of business and society

\begin{tabular}{|c|c|c|c|c|c|}
\hline \multirow{11}{*}{ 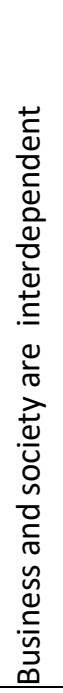 } & Suggestion & & $\begin{array}{l}\text { MNCs } \\
(n=30)\end{array}$ & $\begin{array}{l}\text { Indian private } \\
(n=26)\end{array}$ & $\begin{array}{l}\text { PSEs } \\
(n=37)\end{array}$ \\
\hline & \multirow{2}{*}{ Disagree } & Count & 0 & 0 & 0 \\
\hline & & $\%$ of total & 0 & 0 & 0 \\
\hline & \multirow{2}{*}{$\begin{array}{l}\text { Agree to some extent } \\
(25 \%)\end{array}$} & Count & 0 & 0 & 3 \\
\hline & & $\%$ of total & 0 & 0 & 8.1 \\
\hline & \multirow{2}{*}{$\begin{array}{l}\text { Agree to a certain } \\
\text { extent }(50 \%)\end{array}$} & Count & 0 & 2 & 0 \\
\hline & & $\%$ of total & 0 & 7.7 & 0 \\
\hline & \multirow{2}{*}{$\begin{array}{l}\text { Agree to a great } \\
\text { extent }(75 \%)\end{array}$} & Count & 0 & 0 & 4 \\
\hline & & $\%$ of total & 0 & 0 & 10.8 \\
\hline & \multirow{2}{*}{ Agree fully (100\%) } & Count & 30 & 24 & 30 \\
\hline & & $\%$ of total & 100 & 92.3 & 81.1 \\
\hline
\end{tabular}

All the MNCs (100\%), most of the Indian private sector firms (92.3\%) and a majority of public sector enterprises (81.1\%) fully agree that a company should acknowledge the interdependence between society and the company.

\subsection{Environmental friendliness}

\subsubsection{Care of natural environment}

Views of companies with regard to promoting environmental friendliness by taking care of the natural environment

\begin{tabular}{|c|c|c|c|c|c|}
\hline \multirow{11}{*}{ 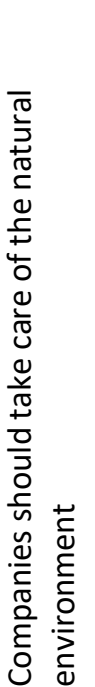 } & Suggestion & & $\begin{array}{l}\text { MNCs } \\
(n=30)\end{array}$ & $\begin{array}{l}\text { Indian private } \\
(\mathrm{n}=26)\end{array}$ & $\begin{array}{l}\text { PSEs } \\
(n=37)\end{array}$ \\
\hline & \multirow{2}{*}{ Disagree } & Count & 0 & 0 & 0 \\
\hline & & $\%$ of total & 0 & 0 & 0 \\
\hline & \multirow{2}{*}{$\begin{array}{l}\text { Agree to some extent } \\
(25 \%)\end{array}$} & Count & 0 & 0 & 0 \\
\hline & & $\%$ of total & 0 & 0 & 0 \\
\hline & \multirow{2}{*}{$\begin{array}{l}\text { Agree to a certain } \\
\text { extent (50\%) }\end{array}$} & Count & 0 & 0 & 2 \\
\hline & & $\%$ of total & 0 & 0 & 5.4 \\
\hline & \multirow{2}{*}{$\begin{array}{l}\text { Agree to a great } \\
\text { extent }(75 \%)\end{array}$} & Count & 0 & 2 & 7 \\
\hline & & $\%$ of total & 0 & 7.7 & 18.9 \\
\hline & \multirow{2}{*}{ Agree fully (100\%) } & Count & 30 & 24 & 28 \\
\hline & & $\%$ of total & 100 & 92.3 & 75.7 \\
\hline
\end{tabular}

All the MNCs (100\%), most of the Indian private sector firms (92.3\%) and a majority of public sector enterprises (75.7\%) fully agree that a company should acknowledge the need to care for the environment. 


\subsubsection{Avoiding damage to the environment}

Views of companies in promoting environmental friendliness by avoiding damage to natural environment

\begin{tabular}{|c|c|c|c|c|c|}
\hline \multirow{11}{*}{ 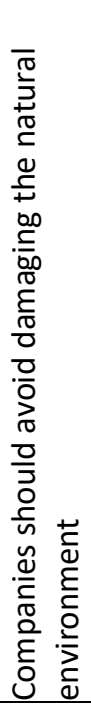 } & Suggestion & & $\begin{array}{l}\text { MNCs } \\
(n=30)\end{array}$ & $\begin{array}{l}\text { Indian private } \\
(\mathrm{n}=26)\end{array}$ & $\begin{array}{l}\text { PSES } \\
(n=37)\end{array}$ \\
\hline & \multirow{2}{*}{ Disagree } & Count & 0 & 0 & 0 \\
\hline & & $\%$ of total & 0 & 0 & 0 \\
\hline & \multirow{2}{*}{$\begin{array}{l}\text { Agree to some extent } \\
(25 \%)\end{array}$} & Count & 0 & 0 & 0 \\
\hline & & $\%$ of total & 0 & 0 & 0 \\
\hline & \multirow{2}{*}{$\begin{array}{l}\text { Agree to a certain } \\
\text { extent }(50 \%)\end{array}$} & Count & 0 & 2 & 0 \\
\hline & & $\%$ of total & 0 & 7.7 & 0 \\
\hline & \multirow{2}{*}{$\begin{array}{l}\text { Agree to a great } \\
\text { extent }(75 \%)\end{array}$} & Count & 0 & 0 & 5 \\
\hline & & $\%$ of total & 0 & 0 & 13.5 \\
\hline & \multirow{2}{*}{ Agree fully (100\%) } & Count & 30 & 24 & 32 \\
\hline & & $\%$ of total & 100 & 92.3 & 86.5 \\
\hline
\end{tabular}

All the MNCs (100\%), most of the Indian private sector firms (92.3\%) and a majority of the public sector enterprises (86.5\%) fully agree that a company should acknowledge the need to prevent damage to the natural environment.

\subsubsection{Contributing to upkeep of the environment}

Views of companies towards environment by understanding the need to upkeep natural environment

\begin{tabular}{|c|c|c|c|c|c|}
\hline \multirow{11}{*}{ 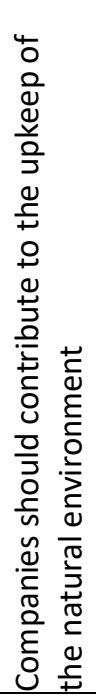 } & Suggestion & & $\begin{array}{l}\text { MNCs } \\
(n=30)\end{array}$ & $\begin{array}{l}\text { Indian private } \\
(n=26)\end{array}$ & $\begin{array}{l}\text { PSES } \\
(n=37)\end{array}$ \\
\hline & \multirow{2}{*}{ Disagree } & Count & 0 & 0 & 0 \\
\hline & & $\%$ of total & 0 & 0 & 0 \\
\hline & \multirow{2}{*}{$\begin{array}{l}\text { Agree to some extent } \\
(25 \%)\end{array}$} & Count & 0 & 0 & 0 \\
\hline & & $\%$ of total & 0 & 0 & 0 \\
\hline & \multirow{2}{*}{$\begin{array}{l}\text { Agree to a certain } \\
\text { extent }(50 \%)\end{array}$} & Count & 0 & 2 & 2 \\
\hline & & $\%$ of total & 0 & 7.7 & 5.4 \\
\hline & \multirow{2}{*}{$\begin{array}{l}\text { Agree to a great } \\
\text { extent }(75 \%)\end{array}$} & Count & 2 & 0 & 9 \\
\hline & & $\%$ of total & 6.7 & 0 & 24.3 \\
\hline & \multirow{2}{*}{ Agree fully (100\%) } & Count & 28 & 24 & 26 \\
\hline & & $\%$ of total & 93.3 & 92.3 & 70.3 \\
\hline
\end{tabular}

Most of the MNCs (93.3\%), most of the Indian private sector firms (92.3\%) and a majority of PSEs (70.3\%) agree fully that a company should acknowledge the need to provide resources to upkeep the natural environment. 


\subsubsection{Need for recycling \& environment friendliness}

Views of companies towards environment friendliness through waste minimization and recycling

\begin{tabular}{|c|c|c|c|c|c|}
\hline \multirow{11}{*}{ 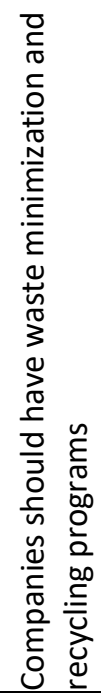 } & Suggestion & & $\begin{array}{l}\text { MNCs } \\
(n=30)\end{array}$ & $\begin{array}{l}\text { Indian private } \\
(\mathrm{n}=26)\end{array}$ & $\begin{array}{l}\text { PSEs } \\
(n=37)\end{array}$ \\
\hline & \multirow{2}{*}{ Disagree } & Count & 0 & 0 & 0 \\
\hline & & $\%$ of total & 0 & 0 & 0 \\
\hline & \multirow{2}{*}{$\begin{array}{l}\text { Agree to some extent } \\
(25 \%)\end{array}$} & Count & 0 & 0 & 0 \\
\hline & & $\%$ of total & 0 & 0 & 0 \\
\hline & \multirow{2}{*}{$\begin{array}{l}\text { Agree to a certain } \\
\text { extent }(50 \%)\end{array}$} & Count & 0 & 0 & 3 \\
\hline & & $\%$ of total & 0 & 0 & 8.1 \\
\hline & \multirow{2}{*}{$\begin{array}{l}\text { Agree to a great extent } \\
(75 \%)\end{array}$} & Count & 3 & 2 & 9 \\
\hline & & $\%$ of total & 10 & 7.7 & 24.3 \\
\hline & \multirow{2}{*}{ Agree fully (100\%) } & Count & 27 & 24 & 25 \\
\hline & & $\%$ of total & 90 & 92.3 & 67.6 \\
\hline
\end{tabular}

Most of MNC companies (90\%); most of the Indian private sector firms (92.3\%) and a majority of public sector enterprises (67.6\%) fully agree that a company should minimise waste and acknowledge the need to recycle. 


\section{ANNEXURE V}

\section{RESIDUAL STATISTICS \& GRAPHS PLOTTED UNDER REGRESSION1 FOR ALL COMPANIES}

The residual statistics for MNCs are given in table below:

Residuals Statistics for MNCs under Regression 1 (R1)

\begin{tabular}{|l|l|l|l|l|l|l|}
\hline \multicolumn{2}{|l|}{ Types of organization } & Minimum & Maximum & Mean & $\begin{array}{l}\text { Std. } \\
\text { Deviation }\end{array}$ & N \\
\hline \multirow{4}{*}{ MNC } & Predicted Value & 2.9892 & 105.2353 & 69.1667 & 26.53419 & 30 \\
\cline { 2 - 7 } & Residual & -20.13514 & 25.75194 & .00000 & 8.46283 & 30 \\
\cline { 2 - 7 } & Std. Predicted Value & -2.494 & 1.359 & .000 & 1.000 & 30 \\
\cline { 2 - 7 } & Std. Residual & -1.822 & 2.330 & .000 & .766 & 30 \\
\hline
\end{tabular}

(Dependent variable: Value creation)

The residual statistics for Indian private companies are given in table below.

Residuals Statistics for Indian private under R1

\begin{tabular}{|l|l|l|l|l|l|l|}
\hline \multicolumn{2}{|l|}{ Types of organization } & Minimum & Maximum & Mean & $\begin{array}{l}\text { Std. } \\
\text { Deviation }\end{array}$ & N \\
\hline \multirow{4}{*}{$\begin{array}{l}\text { Indian } \\
\text { Private }\end{array}$} & Predicted Value & 12.8143 & 87.4526 & 54.5673 & 22.07306 & 26 \\
\cline { 2 - 7 } & Residual & -7.10473 & 6.79267 & .00000 & 2.26889 & 26 \\
\cline { 2 - 7 } & Std. Predicted Value & -1.892 & 1.490 & .000 & 1.000 & 26 \\
\cline { 2 - 7 } & Std. Residual & -2.258 & 2.159 & .000 & .721 & 26 \\
\hline
\end{tabular}

The residual statistics for PSEs are given in table below

Residuals Statistics among PSEs under R1

\begin{tabular}{|l|l|r|r|r|r|r|}
\hline \multicolumn{2}{|l|}{ Types of organization } & Minimum & Maximum & Mean & $\begin{array}{c}\text { Std. } \\
\text { Deviation }\end{array}$ & $\mathrm{N}$ \\
\hline \multirow{4}{*}{ PSE } & Predicted Value & 1.7212 & 95.3835 & 52.8716 & 23.28508 & 37 \\
\cline { 2 - 7 } & Residual & -21.35751 & 18.22812 & .00000 & 10.17971 & 37 \\
\cline { 2 - 7 } & Std. Predicted Value & -2.197 & 1.826 & .000 & 1.000 & 37 \\
\cline { 2 - 7 } & Std. Residual & -1.713 & 1.462 & .000 & .816 & 37 \\
\hline
\end{tabular}

(Dependent Variable: Value creation) 
The graphs are plotted under Regression 1 for MNCs are as follows:

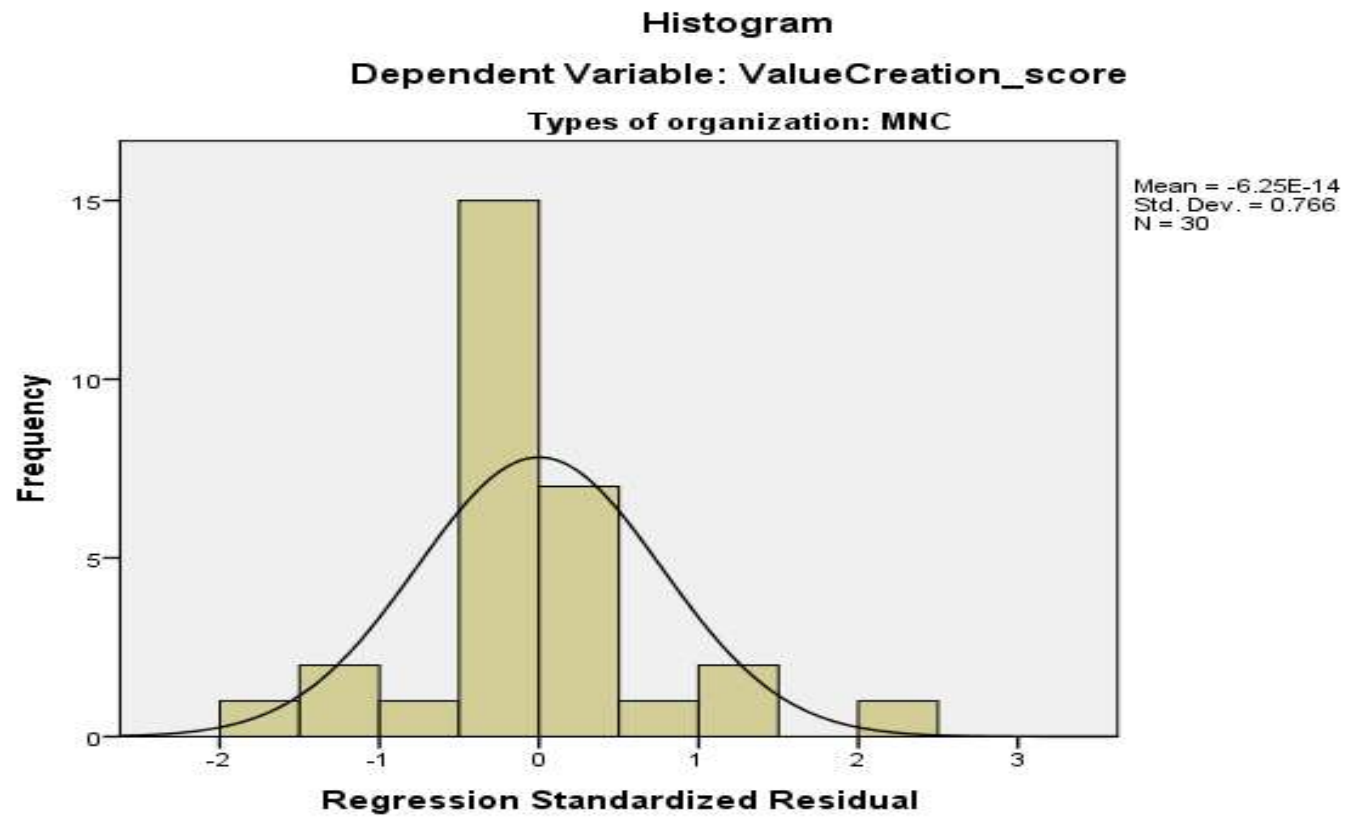

Test of normality for MNCs under R1 (Histogram on ZRESID versus frequency)

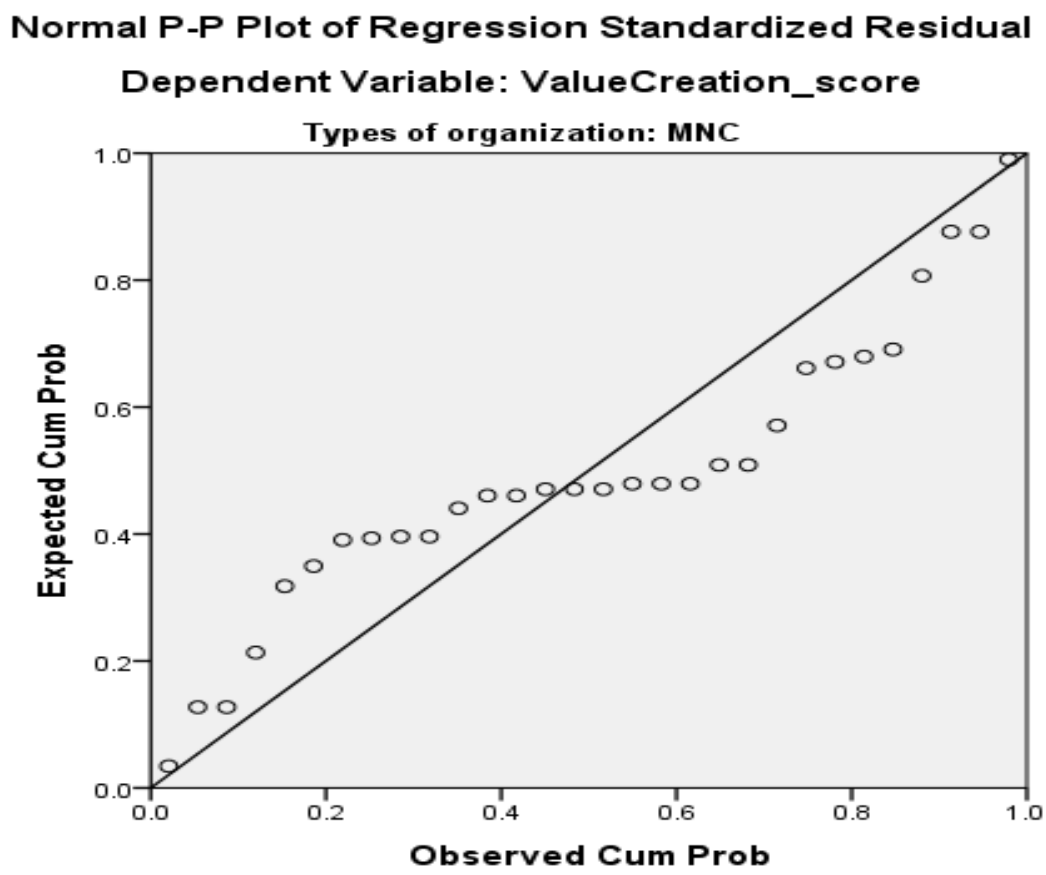

Test of normality for MNCs under R1 (Normal plot of ZRESID) 


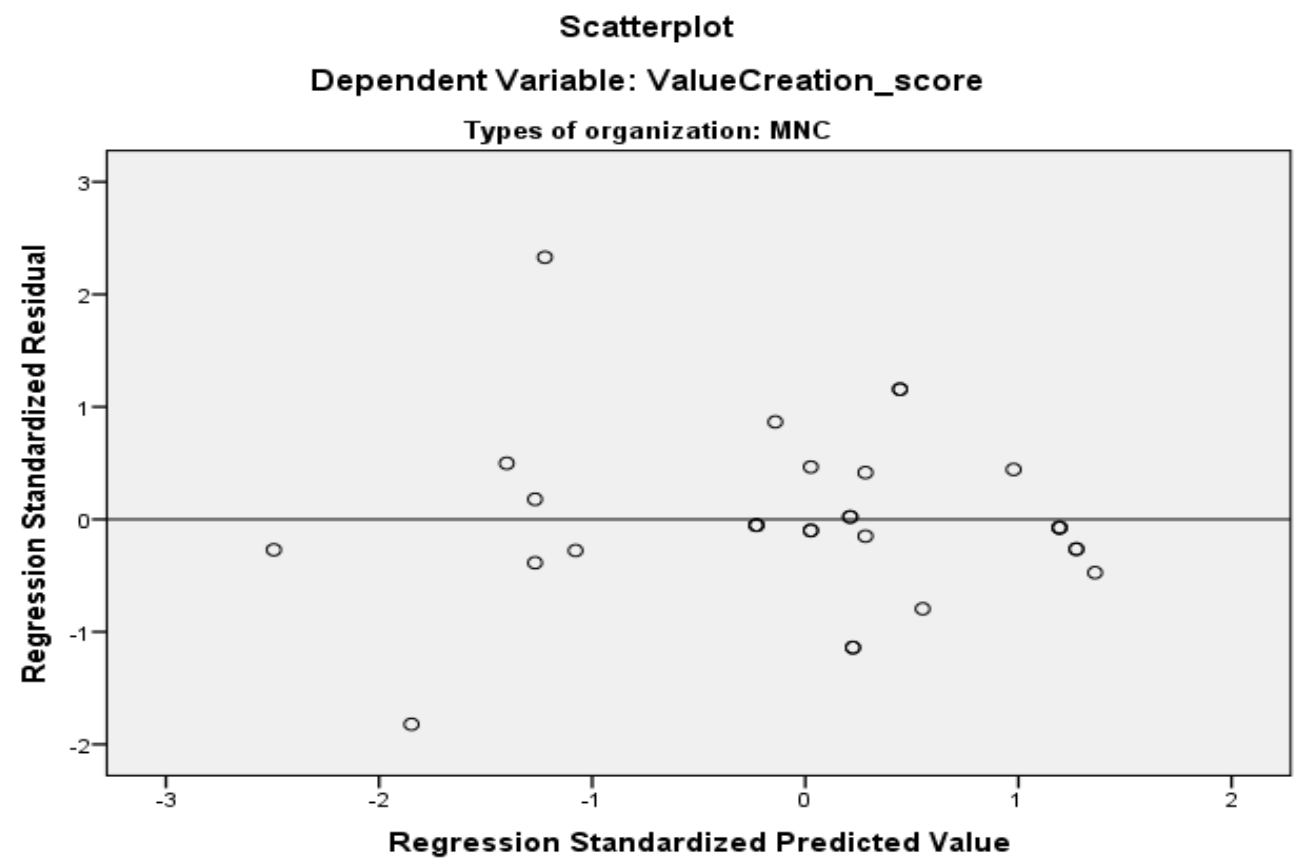

Test to detect heteroscedasticity for MNCs under R1 (ZPRED and ZRESID)

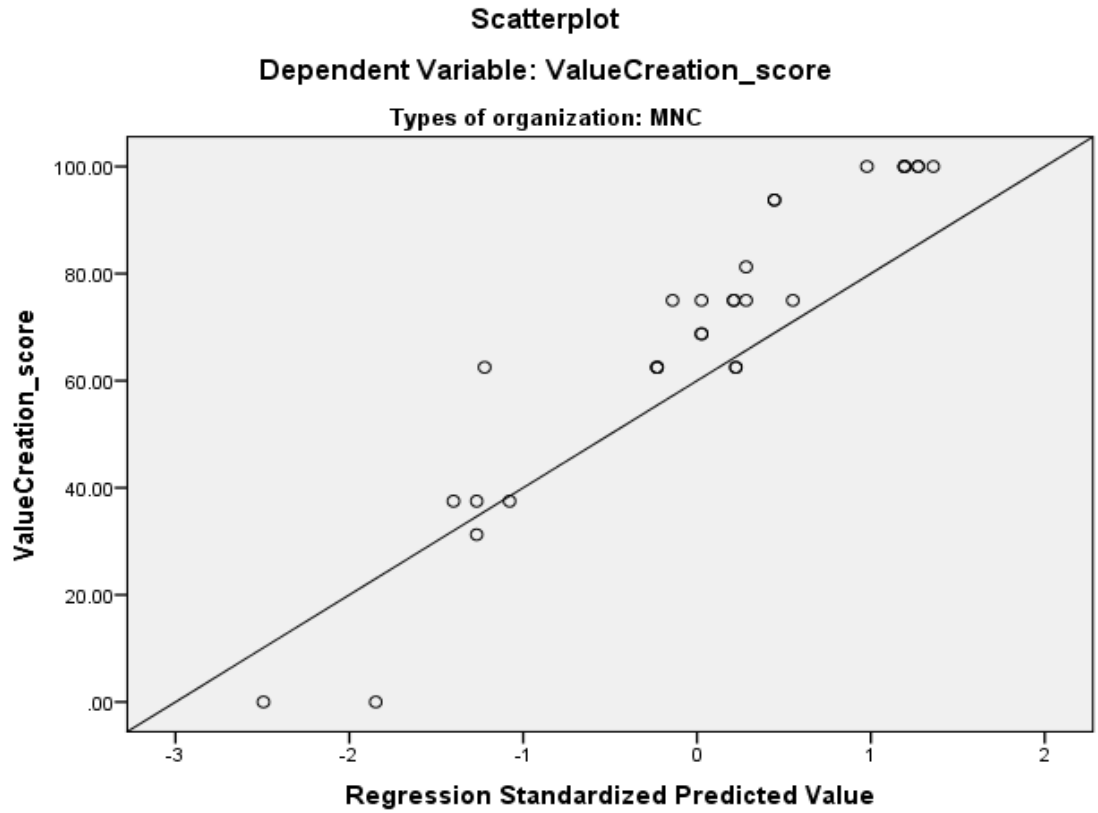

Test of linearity for MNCs under R1 (ZPRED versus value creation) 
The graphs are plotted under Regression 1 for Indian private are as follows:

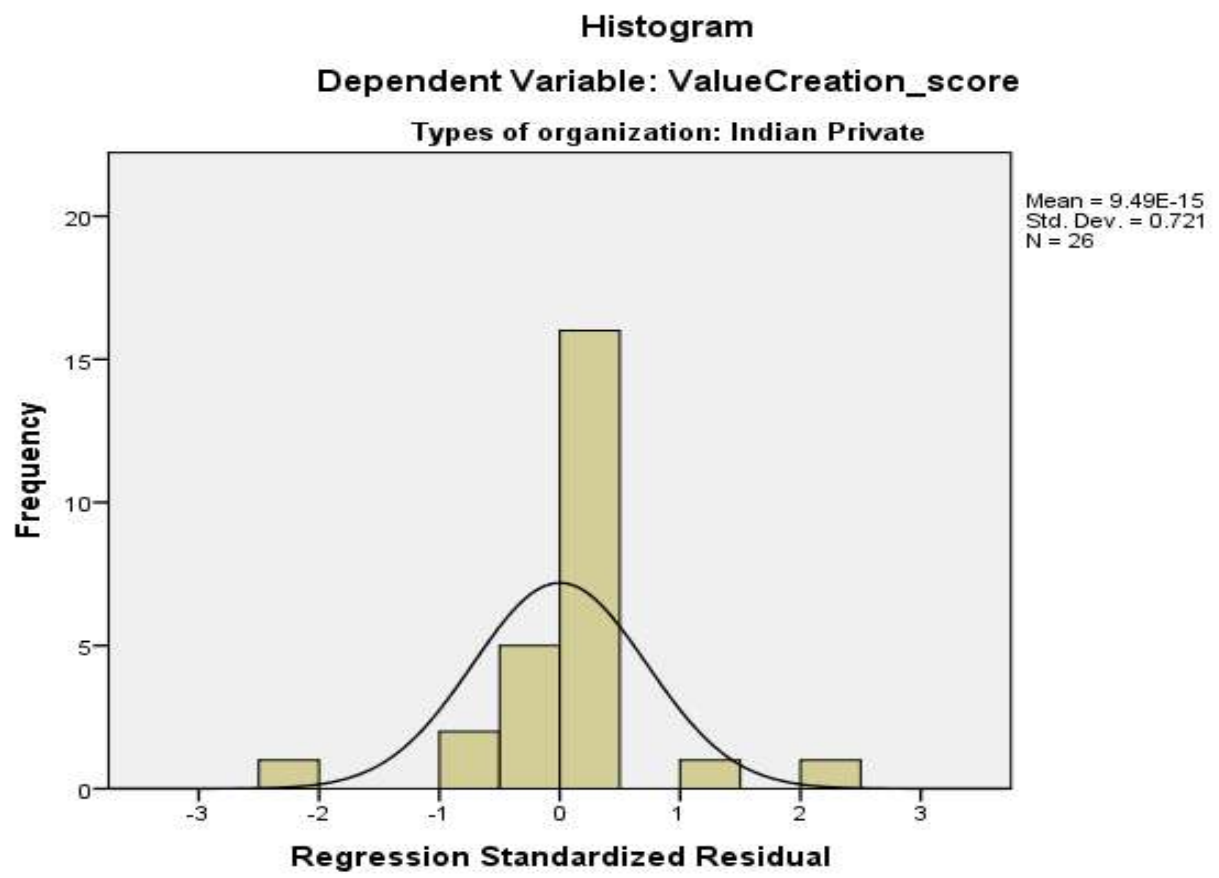

Test for Normality for Indian private under R1 (Histogram on ZRESID versus frequency)

Normal P-P Plot of Regression Standardized Residual Dependent Variable: ValueCreation_score

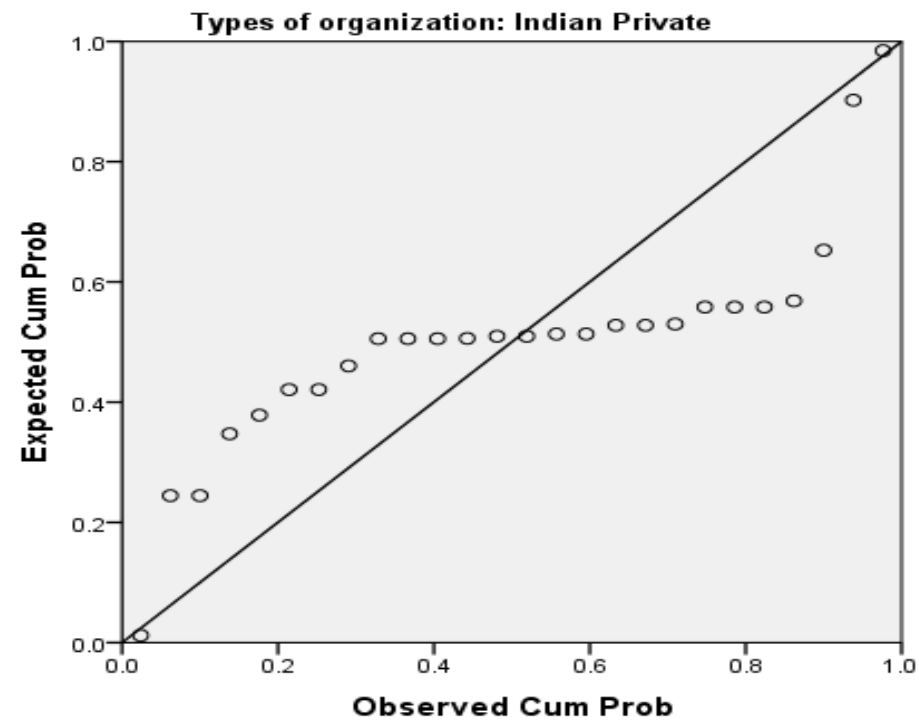

Test for normality for Indian private under R1 (Normal plot of ZRESID) 


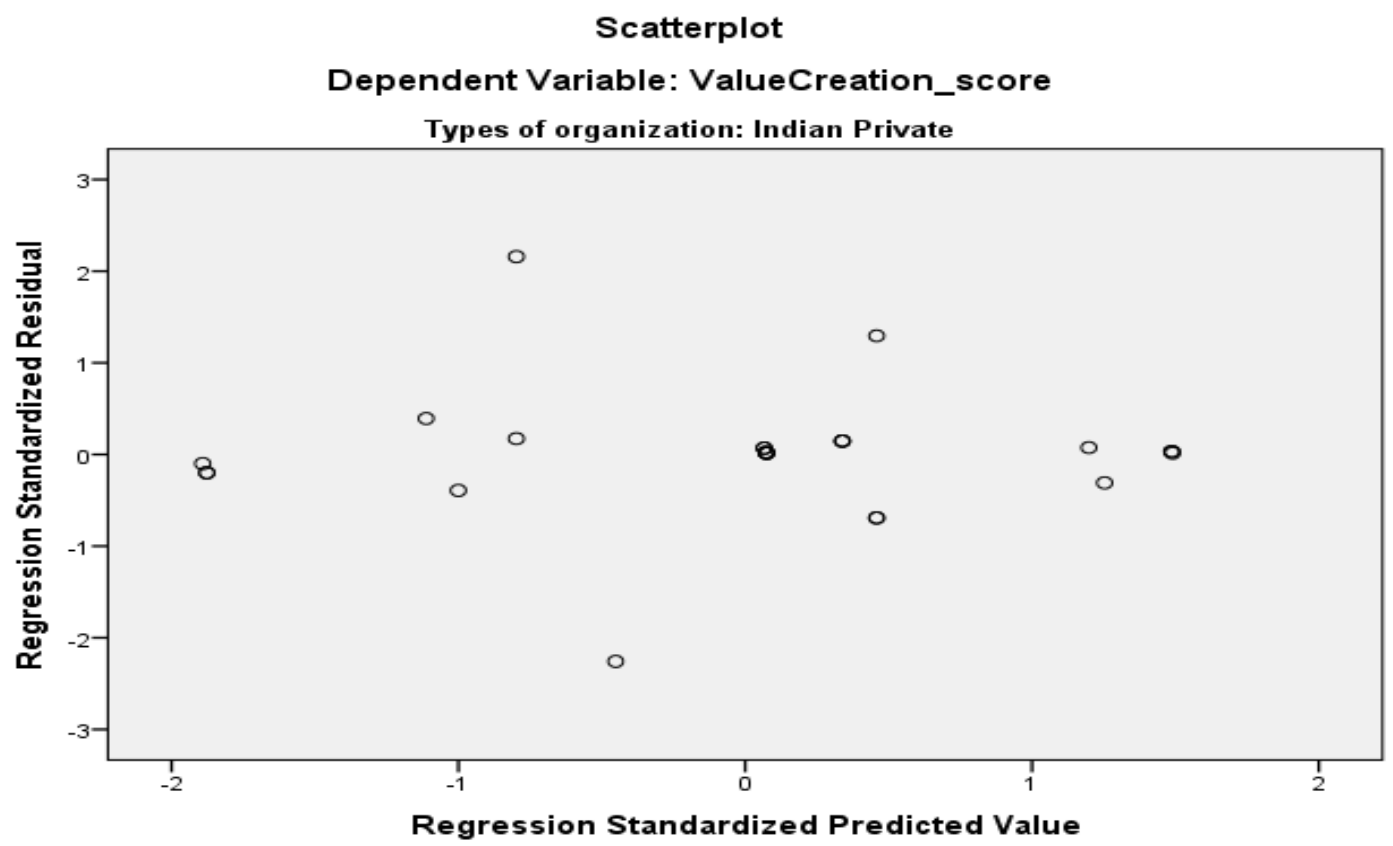

Test for heteroscedasticity for Indian Private under R1 (ZPRED and ZRESID)

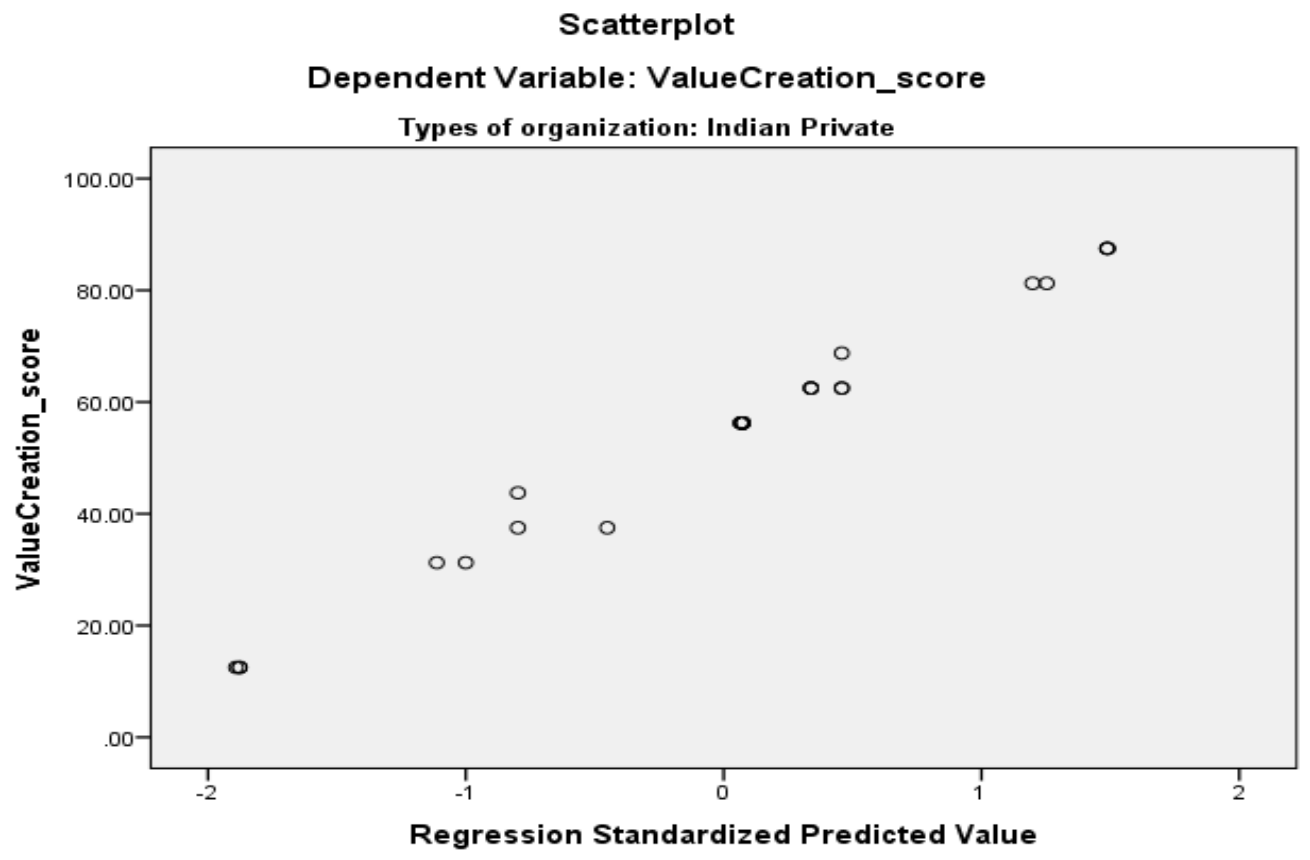

Test of linearity for Indian private under R1 (ZPRED versus value creation) 
The graphs are plotted under Regression 1 for PSEs are as follows:

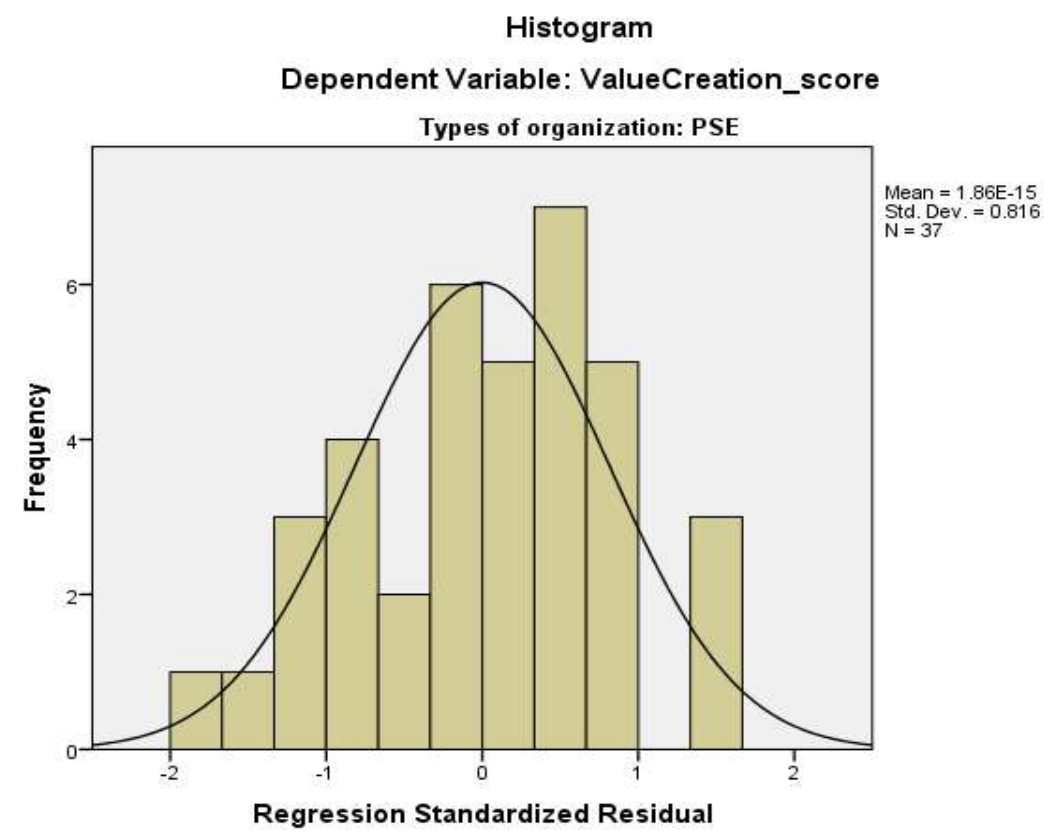

Test of normality for PSEs under R1 (Histogram on ZRESID versus frequency)

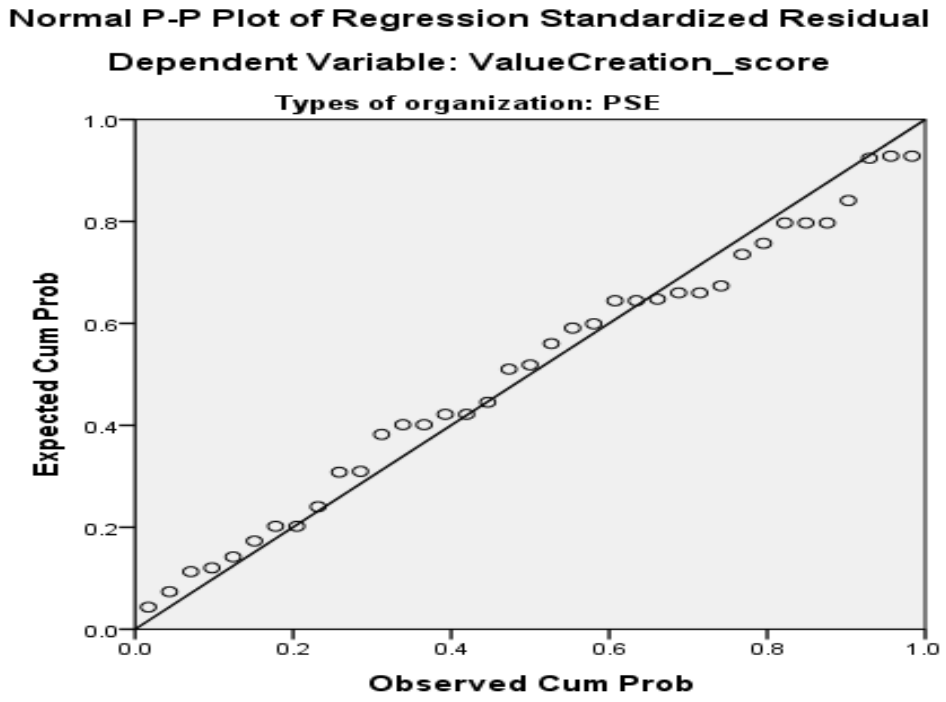

Test of normality for PSEs under R1 (Normal plot of ZRESID) 


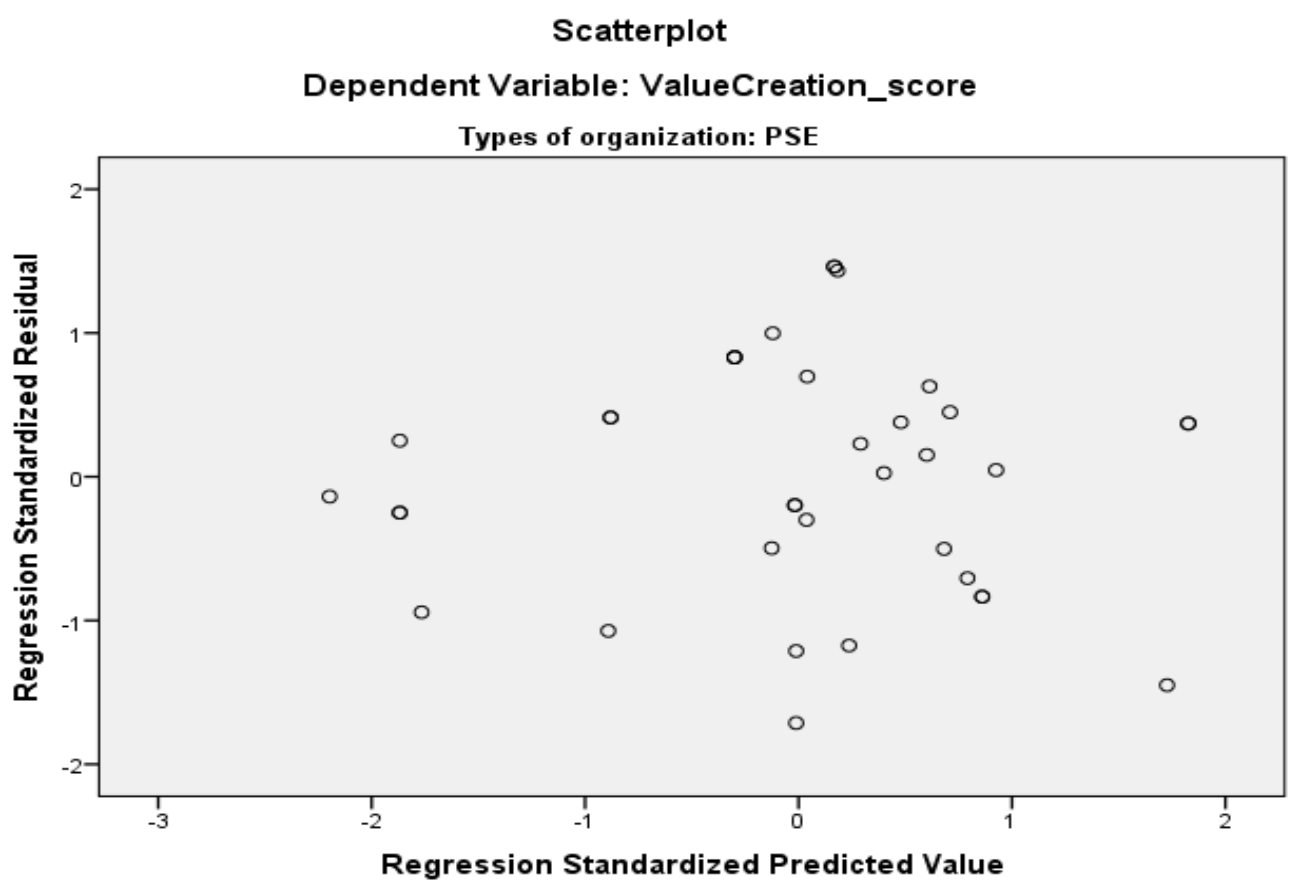

Test for heteroscedasticity for PSEs under R1 (ZPRED and ZRESID)

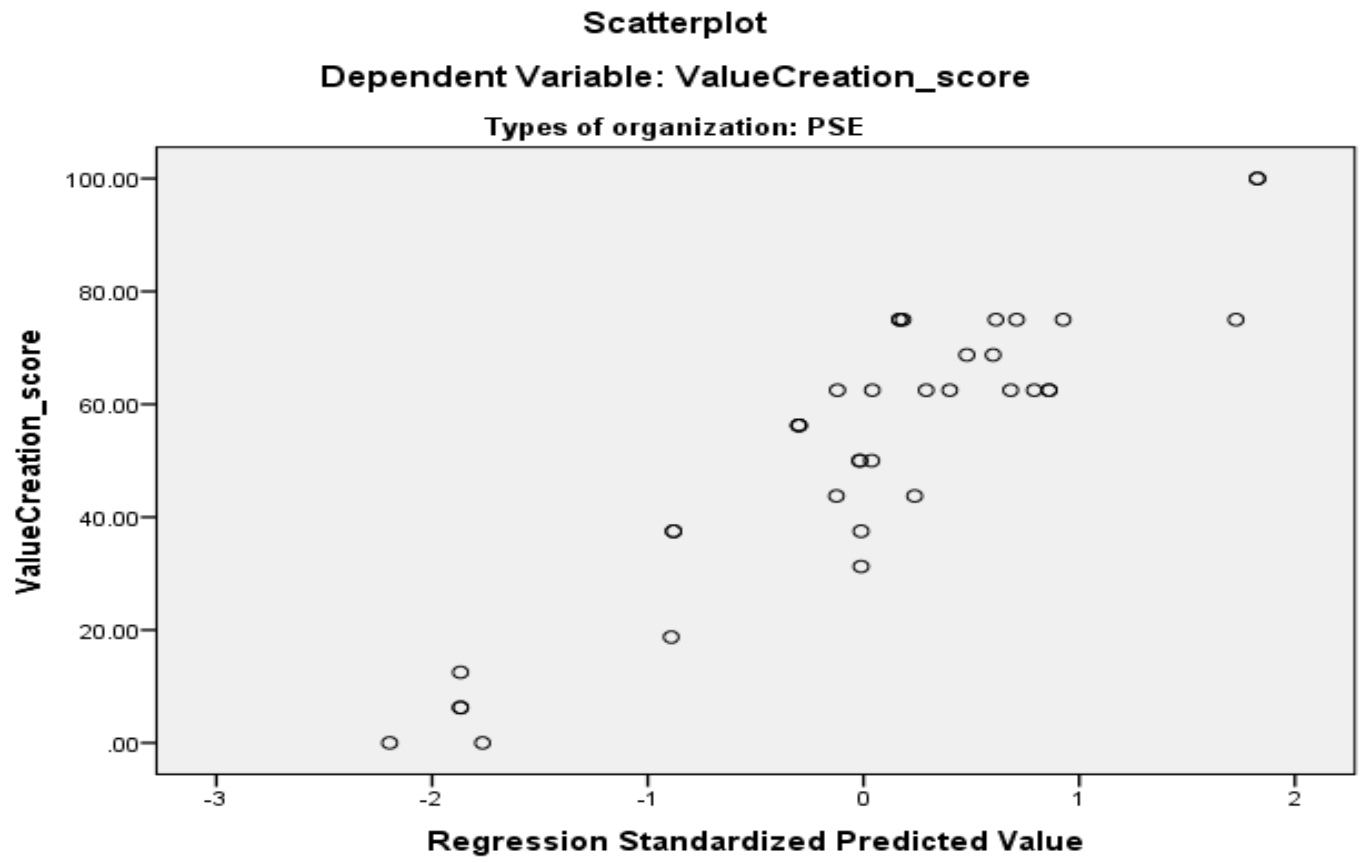

Test for linearity for PSEs under R1 (ZPRED versus value creation) 


\section{ANNEXURE VI}

\section{RESIDUAL STATISTICS OF REGRESSION2 FOR ALL COMPANIES}

The residuals statistics for MNCs under regression 2 is given in table below.

Residuals Statistics for MNCs under R2

\begin{tabular}{|l|l|r|r|r|r|r|}
\hline \multicolumn{2}{|l|}{ Types of organization } & Minimum & Maximum & Mean & \multicolumn{1}{c|}{$\begin{array}{c}\text { Std. } \\
\text { Deviation }\end{array}$} & N \\
\hline \multirow{3}{*}{ MNC } & Predicted Value & 2.9892 & 105.2353 & 69.1667 & 26.53419 & 30 \\
\cline { 2 - 7 } & Residual & -20.13514 & 25.75194 & .00000 & 8.46283 & 30 \\
\cline { 2 - 7 } & Std. Predicted Value & -2.494 & 1.359 & .000 & 1.000 & 30 \\
\cline { 2 - 7 } & Std. Residual & -1.822 & 2.330 & .000 & .766 & 30 \\
\hline
\end{tabular}

(Dependent variable: Value creation)

The residuals statistics for Indian private companies under regression 2 is given in table below.

Residuals Statistics for Indian Private companies under R2

\begin{tabular}{|l|l|r|r|r|r|r|}
\hline \multicolumn{2}{|l|}{ Types of organization } & Minimum & Maximum & Mean & \multicolumn{1}{c|}{$\begin{array}{c}\text { Std. } \\
\text { Deviation }\end{array}$} & N \\
\hline \multirow{3}{*}{$\begin{array}{l}\text { Indian } \\
\text { Private }\end{array}$} & Predicted Value & 12.8143 & 87.4526 & 54.5673 & 22.07306 & 26 \\
\cline { 2 - 7 } & Residual & -7.10473 & 6.79267 & .00000 & 2.26889 & 26 \\
\cline { 2 - 7 } & Std. Predicted Value & -1.892 & 1.490 & .000 & 1.000 & 26 \\
\cline { 2 - 7 } & Std. Residual & -2.258 & 2.159 & .000 & .721 & 26 \\
\hline
\end{tabular}

(Dependent variable: Value creation)

The residuals statistics for PSEs under regression 2 is given in table below.

Residual Statistics for PSEs under R2

\begin{tabular}{|l|l|r|r|r|r|r|}
\hline \multicolumn{2}{|l|}{ Types of organization } & Minimum & Maximum & \multicolumn{1}{|c|}{ Mean } & \multicolumn{1}{c|}{$\begin{array}{c}\text { Std. } \\
\text { Deviation }\end{array}$} & N \\
\hline \multirow{4}{*}{ PSE } & Predicted Value & 1.7212 & 95.3835 & 52.8716 & 23.28508 & 37 \\
\cline { 2 - 7 } & Residual & -21.35751 & 18.22812 & .00000 & 10.17971 & 37 \\
\cline { 2 - 7 } & Std. Predicted Value & -2.197 & 1.826 & .000 & 1.000 & 37 \\
\cline { 2 - 7 } & Std. Residual & -1.713 & 1.462 & .000 & .816 & 37 \\
\hline
\end{tabular}

(Dependent variable: Value creation) 
ANNEXURE VII

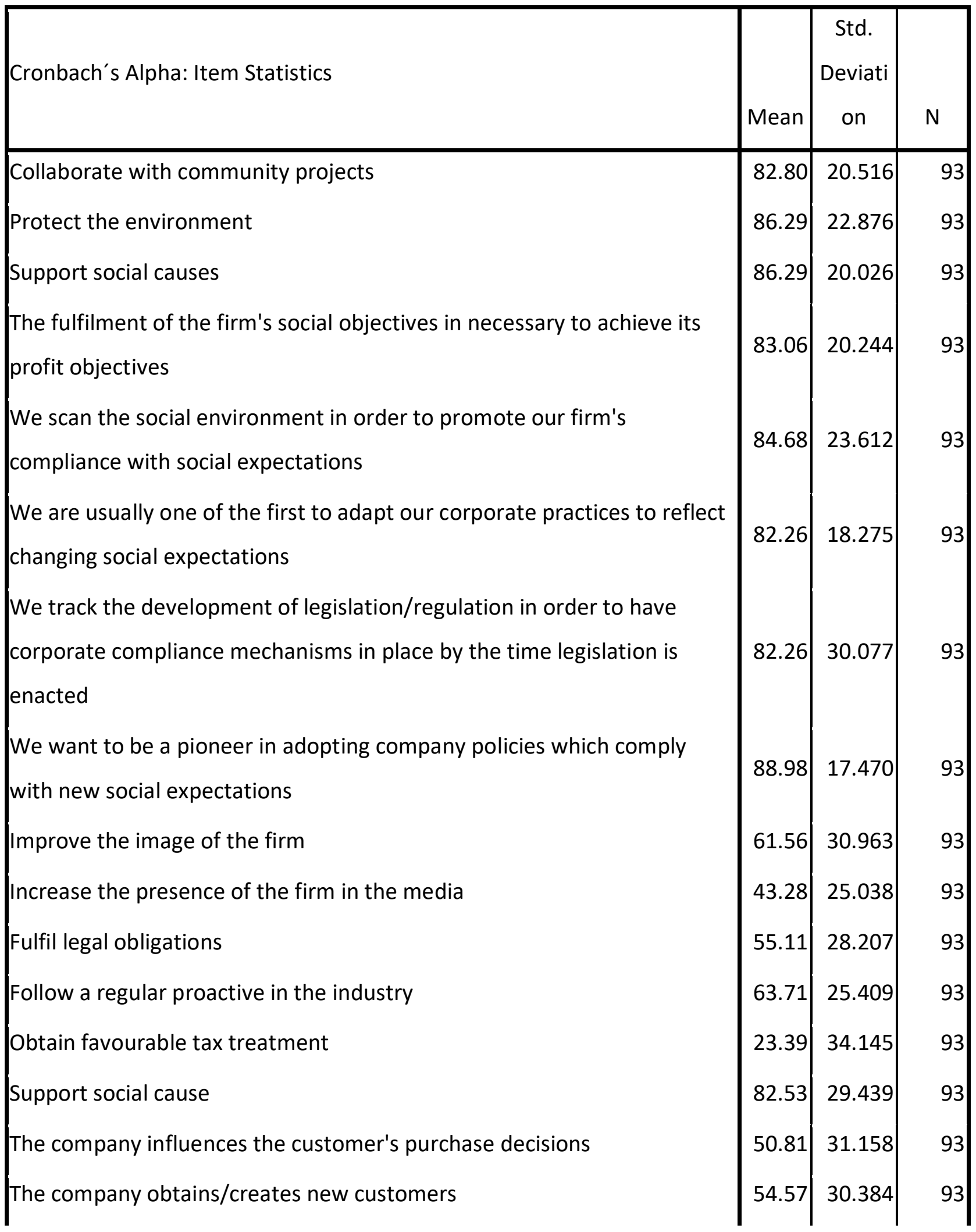




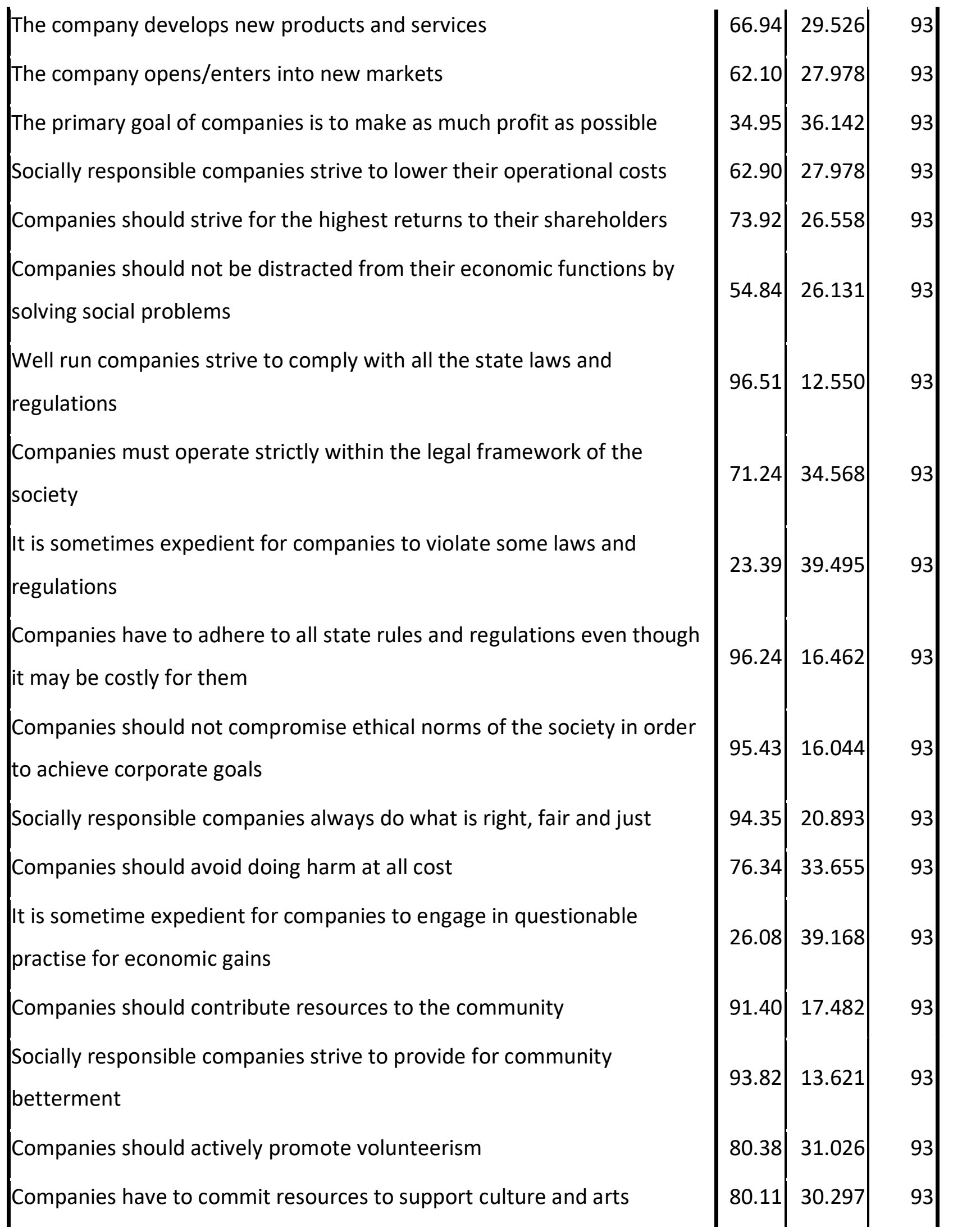




\begin{tabular}{|c|c|c|c|}
\hline Business has an obligation to needy persons in the society & 78.76 & 25.788 & 93 \\
\hline Business should be charitable toward the less fortune in the society & 75.54 & 30.835 & 93 \\
\hline Companies should take voluntary actions to promote social good & 85.75 & 19.643 & 93 \\
\hline Socially responsible companies contribute to charitable organizations & 74.73 & 30.506 & 93 \\
\hline $\begin{array}{l}\text { Business has an obligation to see that everyone in the society benefits } \\
\text { from its actions }\end{array}$ & 84.14 & 26.008 & 93 \\
\hline $\begin{array}{l}\text { Business should consider the interest of all who are affected by its } \\
\text { decisions and actions }\end{array}$ & 88.71 & 18.251 & 93 \\
\hline $\begin{array}{l}\text { Business should balance the interests and needs of different groups in } \\
\text { the society }\end{array}$ & 83.06 & 31.743 & 93 \\
\hline Business and society are interdependent & 94.89 & 15.880 & 93 \\
\hline Companies should take care of the natural environment & 95.97 & 11.824 & 93 \\
\hline Companies should avoid damaging the natural environment & 97.58 & 9.077 & 93 \\
\hline Companies should contribute to the upkeep of the natural environment & 94.89 & 12.532 & 93 \\
\hline Companies should have waste minimization and recycling programs & 94.62 & 12.141 & 93 \\
\hline
\end{tabular}

